UNIVERSIDADE DE SÃO PAULO

FACULDADE DE ECONOMIA, ADMINISTRAÇÃO E CONTABILIDADE DE RIBEIRÃO PRETO DEPARTAMENTO DE ADMINISTRAÇÃO

\title{
FLUXOS DE CAPITAIS EXTERNOS, CRESCIMENTO E DESENVOLVIMENTO ECONÔMICO: EVIDÊNCIAS DE CAUSALIDADE
}

\author{
LUCIANO APARECIDO DOS SANTOS PIMENTEL
}

ORIENTADOR - PROF. DR. TABAJARA PIMENTA JR.

RIBEIRÃO PRETO 


\section{Magnífica Reitora da Universidade de São Paulo Profa. Dra. Suely Vilela Sampaio}

Diretor da Faculdade de Economia, Administração e Contabilidade de Ribeirão Preto Prof. Dr. Rudinei Toneto Júnior

Chefe do Departamento de Administração

Prof. Dr. Márcio Mattos Borges de Oliveira 
LUCIANO APARECIDO DOS SANTOS PIMENTEL

\section{Fluxos de Capitais Externos, Crescimento e Desenvolvimento Econômico: Evidências de Causalidade}

Dissertação apresentada à Faculdade de Economia, Administração e Contabilidade de Ribeirão Preto da Universidade de São Paulo para obtenção do título de Mestre em Administração de Organizações

Área de Concentração: Finanças

Orientador: Prof. Dr. Tabajara Pimenta Jr. 


\section{FICHA CATALOGRÁFICA}

PIMENTEL, Luciano Aparecido dos Santos

Fluxos de Capitais Externos, Crescimento e Desenvolvimento

Econômico: Evidências de Causalidade, 2007.

191 p. : il. ; $30 \mathrm{~cm}$

Dissertação de Mestrado, apresentada à Faculdade de Economia, Administração e Contabilidade de Ribeirão Preto/USP Área de concentração: Finanças

Orientador: PIMENTA JUNIOR, Tabajara

1. Finanças. 2. VAR. 3. Causalidade de Granger. 4. Crescimento Econômico. 5. Desenvolvimento. 6. Fluxos de Capitais Externos 


\section{Dedicatória}

À Claudinha, meu amor, pelo companheirismo, carinho, compreensão e apoio em mais uma etapa importante de nossas vidas. Devo isso a você, que vem mudando minha vida para melhor. 


\section{Agradecimentos}

Ao Prof. Dr. Tabajara Pimenta Jr., grande amigo e orientador, que acreditou em mim, mostrou o caminho e me fez crer que era possível.

Aos meus pais, Pimentel e Julia, pelo apoio, estrutura, ensinamentos e exemplo de vida que sempre me deram.

Aos meus irmãos, Adriano e Julio, que sempre dividiram comigo boas histórias e lembranças e, a partir de agora, discussões acadêmicas.

À minha avó Helena, que esteve sempre presente em nossas vidas, compartilhando alegrias e lutas.

Aos meus avós (in memorian) José Ignácio dos Santos, José Pimentel e Regina Pimentel, com saudades.

Aos amigos Marcelo Botelho Costa Moraes e Willy Gentil de Góes, pelas valiosas contribuições e sugestões.

Aos professores André Luiz Oda e Silvio Hiroshi Nakao, pelas contribuições e sugestões proferidas na banca de qualificação.

Aos funcionários da Secretaria de Pós-Graduação e em especial à Eduardo Castaldelli Jr., pela prestatividade e amizade.

Aos professores, colegas de mestrado e demais funcionários da FEA Ribeirão, que participaram, direta e indiretamente, desse processo.

Aos meus amigos e colegas, que sempre me apoiaram.

À Deus, por estar presente em minha vida e assumir o comando em momentos difíceis. 
PIMENTEL, L. A. S. Fluxos de Capitais Externos, Crescimento e Desenvolvimento Econômico: Evidências de Causalidade. Dissertação de Mestrado. FEA USP, Ribeirão Preto, 2007

A redução da pobreza é um problema amplamente discutido no mundo. Por meio do crescimento econômico, os países podem melhorar seu padrão de vida e alcançar maiores níveis de desenvolvimento. Com a abertura promovida no contexto da globalização, houve aumento no fluxo de bens e capitais externos para os países em desenvolvimento, favorecendo seu crescimento econômico. Este trabalho buscou identificar relações de causalidade entre fluxos externos, crescimento e desenvolvimento econômico. Foram utilizados indicadores trimestrais e anuais sugeridos na revisão teórica. Os dados trimestrais foram utilizados para construir um modelo de auto-regressão vetorial (VAR), que verificou relações de causalidade entre as variáveis. Os dados anuais foram utilizados para a análise de regressão. Os resultados sugerem que o crescimento econômico apresenta relações de causalidade com investimento interno, poupança, abertura econômica e produtividade. A produtividade, por sua vez, é influenciada pelo capital humano, investimento estrangeiro direto e progresso tecnológico. $\mathrm{O}$ desenvolvimento econômico apresentou relações de causalidade com educação e renda (aumento e distribuição de renda).

Palavras-Chave: Crescimento Econômico, Desenvolvimento, Fluxos de Capitais Externos, Globalização 
PIMENTEL, L. A. S. External Capital Flows, Economic Growth and Development: Evidences of Causality. Dissertation. FEA USP, Ribeirão Preto, 2007

The poverty reduction is widely discussed around the world. Through the economic growth, the countries can improve their pattern of life and reach high levels of development. The commercial overture promoted by globalization increased the international flows of capital and goods into developing countries and promoted economic growth. This study, tried to identify causality relation among international flows, development and economic growth. Quarterly and annual indicators were used as suggested in the theorist revision. The quarterly data were used to built a vector auto regression model (VAR) to verify causality relation among the variables. The annual data were used to the regression analysis. The results suggest that the economic growth has causality relations with internal investment, savings, economic opening and productivity. The productivity is influenced by human capital, external direct investment and technological progress. The development has causality relations with education and income (increase and distribution).

Keywords: Economic Growth, Development, External Capital Flows, Globalization 


\section{Lista de Gráficos e Ilustrações}

Gráfico 2.1 - Coeficiente de Exportação e crescimento do PIB - Tigres Asiáticos X Brasil . 20

Gráfico 3.1 - Saldo da Balança Comercial e Coeficiente de Abertura (1950-2005) ............. 64

Gráfico 3.2 - Relação entre o montante e o crescimento das Exportações............................ 65

Gráfico 3.3 - Exportações por classe de produto (1974-2005 - em US\$)............................. 66

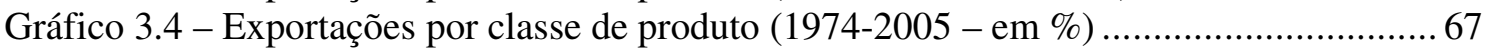

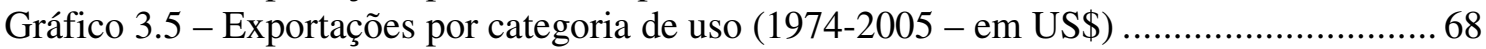

Gráfico 3.6 - Exportações por categoria de uso (1974-2005 - em \%) .................................. 68

Gráfico 4.1 - Evolução do Produto Interno Bruto (R\$ X US\$) ............................................. 87

Gráfico 4.2 - Evolução do Produto Interno Bruto e variação do PIB (2005) ........................ 88

Gráfico 4.3 - Comparativo de Crescimento Econômico do Brasil e do Mundo...................... 88

Gráfico 4.4 - Evolução do Produto Interno Bruto e Produto Nacional Bruto ......................... 89

Gráfico 4.5 - Produtividade da Indústria de Transformação $(1992=100)$.............................. 90

Gráfico 4.6 - Evolução do Investimento Interno e sua participação no PIB ......................... 90

Gráfico 4.7 - Anos de estudo da população em idade ativa e taxa de analfabetismo ............. 91

Gráfico 4.8 - Evolução das receitas e despesas com Royalties e Licenças .......................... 92

Gráfico 4.9 - Crescimento da poupança e sua variação em relação ao PIB .......................... 92

Gráfico 4.10 - Evolução do volume de negócios na Bovespa (em mil R\$) ......................... 93

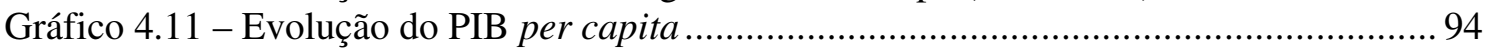

Gráfico 4.12 - Rendimento (renda domiciliar e PIB per capita) .......................................... 95

Gráfico 4.13 - Concentração de Renda (1\% mais ricos e os $50 \%$ mais pobres)..................... 95

Gráfico 4.14 - Concentração de Renda - Coeficiente de Gini X Índice de Theil................... 96

Gráfico 4.15 - Evolução do Índice de Desenvolvimento Humano no Brasil ........................ 97

Gráfico 4.16 - Evolução dos componentes do IDH no Brasil ........................................... 98

Gráfico 4.17 - Evolução do Investimento Estrangeiro Direto e sua relação com o PIB ......... 99

Gráfico 4.18 - Composição do Investimento Estrangeiro Direto ........................................ 99

Gráfico 4.19 - Evolução do Saldo da Balança Comercial e do Coeficiente de Abertura...... 100

Gráfico 4.20 - Evolução das Exportações e Importações................................................. 101

Gráfico 4.21 - Participação brasileira nas exportações e importações mundiais................... 101

Gráfico 4.22 - Relação entre o PIB (R\$ 2005) e o Coeficiente de Exportação ..................... 102

Gráfico 4.23 - Crescimento do PIB (US\$) e o Coeficiente de Exportação ........................... 102

Gráfico 6.1 - Função de Resposta a Impulso para PIB .................................................... 156

Gráfico 6.2 - Função de Resposta a Impulso para Produtividade...................................... 157

Gráfico 6.3 - Função de Resposta a Impulso para Royalties e Licenças............................ 158

Gráfico 6.4 - Função de Resposta a Impulso para Investimento Interno ............................ 159

Gráfico 6.5 - Função de Resposta a Impulso para Poupança ............................................. 160

Gráfico 6.6 - Função de Resposta a Impulso para Investimento Estrangeiro Direto............ 161

Gráfico 6.7 - Função de Resposta a Impulso para Exportação............................................ 162

Gráfico 6.8 - Função de Resposta a Impulso para Coeficiente de Abertura ......................... 163 


\section{Lista de Quadros}

Quadro 2.1 - Crescimento Econômico e Inovação Tecnológica ............................................ 28

Quadro 4.1 - Crescimento Econômico e Comércio Internacional (JAYME JR, 2001) .......... 70

Quadro 4.2 - Crescimento Econômico e Exportações (MATOS, 2003) ................................ 72

Quadro 4.3 - Crescimento Econômico e Exportações (MEDINA-SMITH, 2001) .................. 78

Quadro 4.4 - Relação dos indicadores sugeridos na revisão bibliográfica........................... 86

Quadro 5.1 - Relação dos indicadores para a análise de causalidade de Granger ................ 106

Quadro 5.2 - Relação dos indicadores a para análise de regressão..................................... 106

Quadro 5.3 - Critérios para escolha de defasagens ........................................................ 132

\section{Lista de Tabelas}

Tabela 6.1 - Teste DFA - Valores críticos para verificação de raízes unitárias................... 138

Tabela 6.2 - Estatística t das variáveis para verificação da hipótese nula........................... 138

Tabela 6.3 - Resultado do Teste DFA para PIB............................................................. 139

Tabela 6.4 - Resultado do Teste DFA para Produtividade .............................................. 139

Tabela 6.5 - Resultado do Teste DFA para Royalties e Licenças ........................................ 140

Tabela 6.6 - Resultado do Teste DFA para Investimento Interno .................................... 140

Tabela 6.7 - Resultado do Teste DFA para Poupança.................................................... 141

Tabela 6.8 - Resultado do Teste DFA para Investimento Estrangeiro Direto ...................... 141

Tabela 6.9 - Resultado do Teste DFA para Exportação ................................................ 142

Tabela 6.10 - Resultado do Teste DFA para Coeficiente de Abertura................................ 142

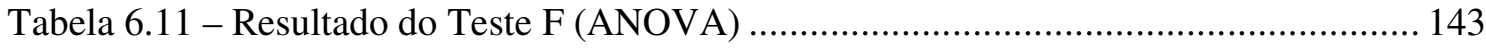

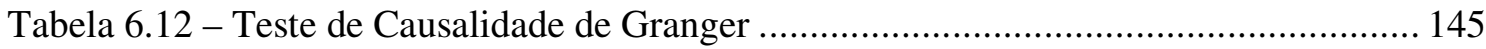

Tabela 6.13 - Decomposição da Variância para PIB ........................................................ 149

Tabela 6.14 - Decomposição da Variância para Produtividade......................................... 149

Tabela 6.15 - Decomposição da Variância para Royalties e Licenças................................. 150

Tabela 6.16 - Decomposição da Variância para Investimento Interno ............................... 150

Tabela 6.17 - Decomposição da Variância para Poupança .............................................. 151

Tabela 6.18 - Decomposição da Variância para Investimento Estrangeiro Direto............... 151

Tabela 6.19 - Decomposição da Variância para Exportação............................................ 152

Tabela 6.20 - Decomposição da Variância para Coeficiente de Abertura ........................... 152

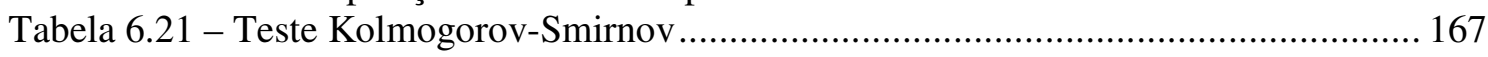

Tabela 6.22 -Modelo de Regressão para Produtividade ................................................ 168

Tabela 6.23 - Modelo de Regressão para IDH........................................................... 169

Tabela 6.24 - Modelo de Regressão para Crescimento Econômico ..................................... 170

Tabela 6.25 - Modelo de Regressão para Desenvolvimento Econômico............................ 171 


\title{
Lista de Siglas e Abreviaturas
}

\author{
ABNT - Associação Brasileira de Normas e Técnicas \\ AIC - Critério de Informação de Akaike \\ AR - Auto-Regressivo \\ ARIMA - Média Móvel Integrada Auto-Regressiva \\ ARMA - Média Móvel Auto-Regressiva \\ BCB - Banco Central do Brasil \\ BOVESPA - Bolsa de Valores de São Paulo \\ CEPAL - Comissão Econômica para a América Latina \\ DFA - Dickey Fuller Aumentado \\ EAADs - Economias Asiáticas de Alto Desempenho \\ FRI - Funções de Resposta ao Impulso \\ FMI - Fundo Monetário Internacional \\ GATT - General Agreement on Tariffs and Trade (Acordo Geral sobre Tarifas e Comércio) \\ IDH - Índice de Desenvolvimento Humano \\ IED - Investimento Estrangeiro Direto \\ IBGE - Instituto Brasileiro de Geografia e Estatística \\ IPEA - Instituto de Pesquisa Econômica Aplicada \\ K-S - Kolmogorov-Smirnov \\ MM - Média Móvel \\ MMAR - Média Móvel Auto-Regressiva \\ PIA - População em Idade Ativa \\ PIB - Produto Interno Bruto \\ PNB - Produto Nacional Bruto \\ PND - Programa Nacional de Desestatitização \\ PNUD - Programa das Nações Unidas para o Desenvolvimento \\ PSI - Processo de Substituição de Importações \\ P\&D - Planejamento e Desenvolvimento \\ RDH - Relatório do Desenvolvimento Humano \\ SC - Schwarz Criterion \\ SPSS - Statistical Package for the Social Sciences (Software para análise estatística) \\ UNCTAD - Conferência das Nações Unidas sobre o Comércio e Desenvolvimento \\ VAR - Auto-Regressão Vetorial
}




\section{SUMÁRIO}

1 INTRODUÇÃ

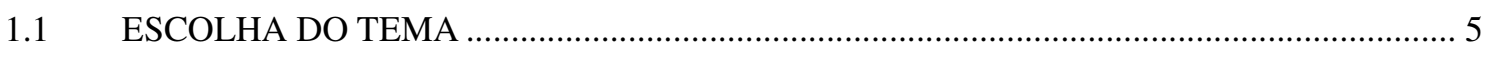

1.2 DEFINIÇÃO DO PROBLEMA DE PESQUISA …...................................................... 5

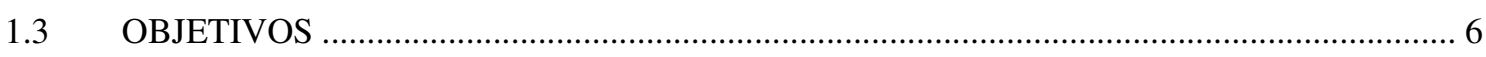

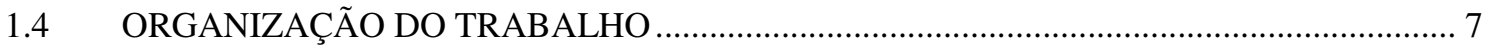

2 CRESCIMENTO E DESENVOLVIMENTO ECONÔMICO.............................................. 9

2.1 EVOLUÇÃO DO PENSAMENTO SOBRE CRESCIMENTO E DESENVOLVIMENTO .. 10

2.2 CONCEITOS RECENTES SOBRE CRESCIMENTO E DESENVOLVIMENTO ............... 15

2.3 REFLEXÕES SOBRE CRESCIMENTO E DESENVOLVIMENTO .................................... 26

2.3.1 CRESCIMENTO ECONÔMICO ................................................................................... 27

2.3.2 DESENVOLVIMENTO ECONÔMICO ….......................................................................... 34

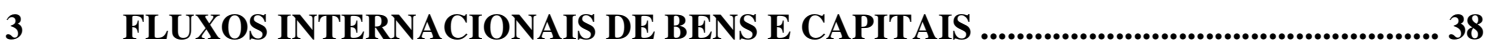

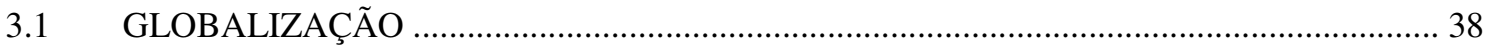

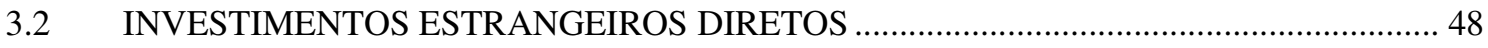

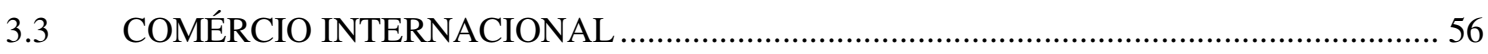

3.3.1 TEORIAS SOBRE COMÉRCIO INTERNACIONAL ……................................................ 56

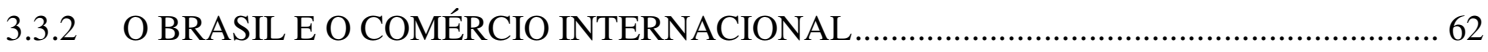

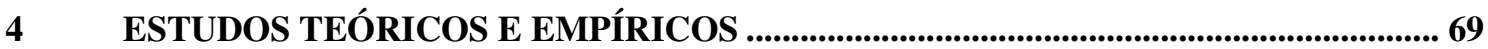

4.1 COMÉRCIO INTERNACIONAL, CRESCIMENTO E DESENVOLVIMENTO .................. 69

4.2 INDICADORES SUGERIDOS PELA REVISÃO BIBLIOGRÁFICA …............................ 79

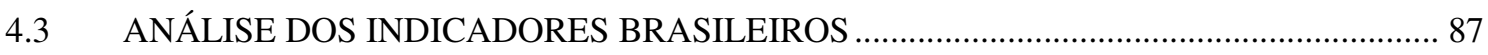

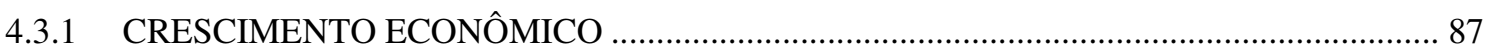

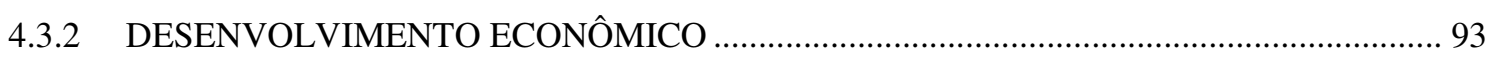

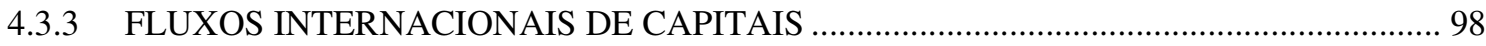

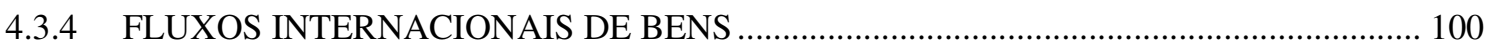

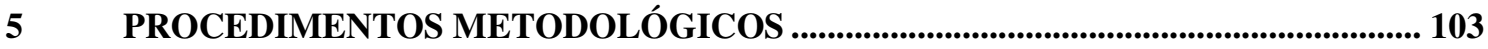

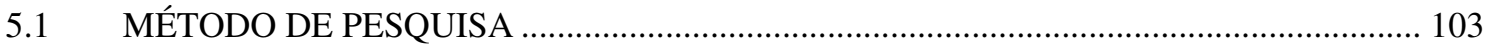

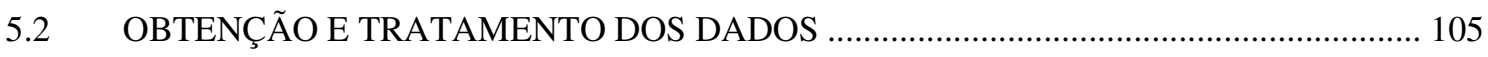

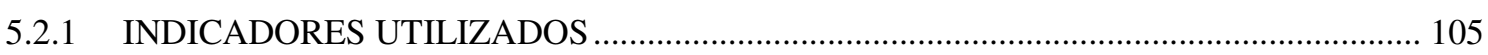

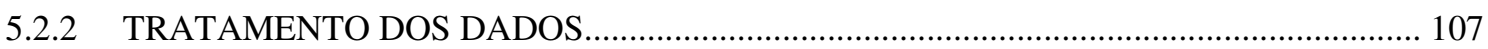

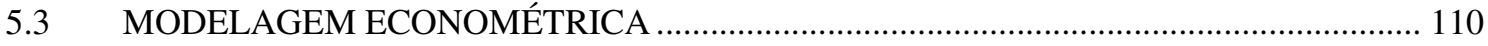

5.3.1 MENSURAÇÃO DE CAUSALIDADE ENTRE VARIÁVEIS ............................................ 113 


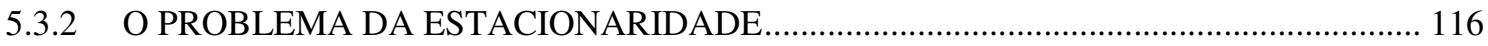

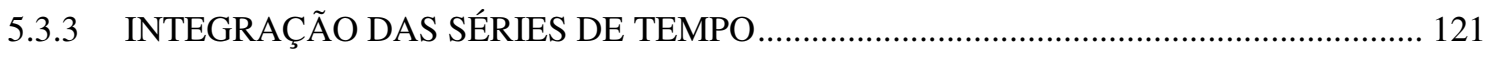

5.3.4 TESTE DE CAUSALIDADE PARA VARIÁVEIS COINTEGRADAS ................................ 124

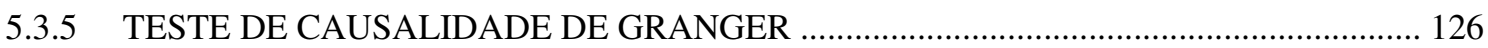

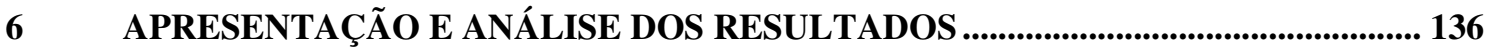

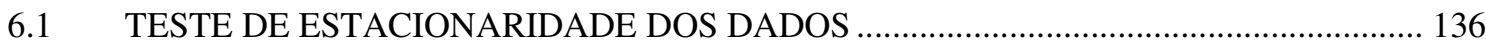

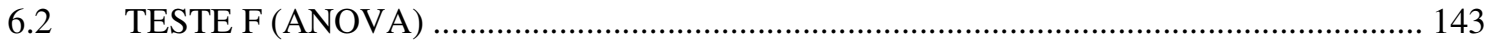

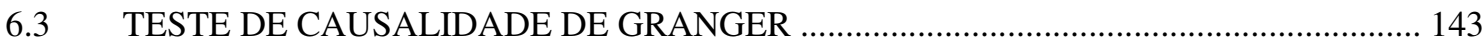

6.4 ANÁLISE DAS DECOMPOSIÇÕES DA VARIÂNCIA …................................................. 148

6.5 ANÁLISE DAS FUNÇÕES DE RESPOSTA AO IMPULSO ….......................................... 155

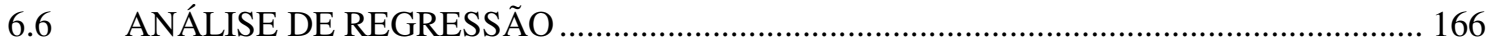

6.6.1 TESTE DE ADERÊNCIA NÃO-PARAMÉTRICO KOLMOGOROV-SMIRNOV ............. 166

6.6.2 ANÁLISE DE REGRESSÃO - PRODUTIVIDADE ......................................................... 168

6.6.3 ANÁLISE DE REGRESSÃO - ÍNDICE DE DESENVOLVIMENTO HUMANO............. 169

6.6.4 ANÁLISE DE REGRESSÃO - CRESCIMENTO ECONÔMICO ......................................... 170

6.6.5 ANÁLISE DE REGRESSÃO - DESENVOLVIMENTO ECONÔMICO............................. 171

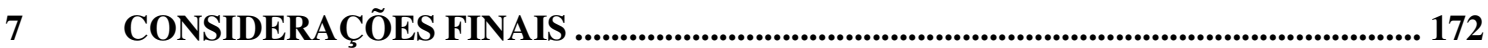

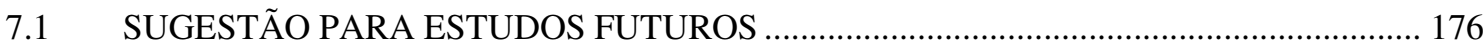

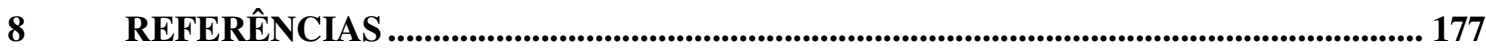




\section{INTRODUÇÃO}

A pobreza é problema básico dos países em desenvolvimento, e sair da pobreza é seu desafio econômico e político (KRUGMAN; OBSTFELD, 2005, p.493). São consideradas pobres todas as pessoas cuja renda é inferior a um valor preestabelecido, denominado linha de pobreza (HOFFMANN, 1998b). Ainda segundo Hoffmann (1998b), a pobreza pode ser medida por meio de suas manifestações, como condições habitacionais inapropriadas, desnutrição das pessoas, incidência de doenças, falta de acesso à serviços básicos, dentre outros.

No Brasil, a necessidade de redução de pobreza e desigualdade é um dos grandes problemas de longo prazo. Com a retomada do crescimento e eficácia dos programas governamentais na década de noventa, o nível da pobreza reduziu, contudo, a desigualdade permanece elevada (CAVALCANTI; FRISCHTAK, 2001).

Por meio do crescimento econômico as gerações podem melhorar seu padrão de vida, pois, ao desfrutar de renda mais alta, podem consumir maiores quantidades de bens e serviços (MANKIW, 1998). Assim, o crescimento econômico, se repensado de forma adequada, de modo a minimizar os impactos ambientais negativos e colocado a serviço de objetivos socialmente desejáveis, continua sendo uma condição necessária para o desenvolvimento (SACHS, 2001).

A liberalização comercial ocorrida na década de noventa, que fomentou o crescimento econômico através do aumento de transações comerciais, promoveu a integração dos países. Segundo Ricupero (2001b), essa integração à economia mundial pode ser virtuosa, permitindo 
a criação de uma sociedade mais igualitária, com menores índices de desigualdades, ou ainda, pode ser perversa, ao perpetuar o atraso econômico, permitir a concentração de riqueza e renda, a exclusão e marginalidade, a instabilidade política e o retardamento educacional, frustrando assim as possibilidades de desenvolvimento.

Um exemplo dessa integração perversa é o caso de países mais desenvolvidos industrialmente que, por serem mais competitivos e disporem de tecnologia e economia de escala, aumentam suas exportações e assim crescem economicamente, enquanto países menos desenvolvidos não conseguem ser competitivos.

Apesar do inegável estímulo ao crescimento econômico proporcionado pela globalização, a percepção da população é que alguns grupos sociais e países ficaram ainda mais pobres com o processo de liberação comercial e que existe uma espécie de conspiração mundial para a exploração dos países mais pobres. (DI SENA JUNIOR, 2004, p. 59)

Ao analisar a competitividade no contexto da globalização, infere-se um dos fatores que pode explicar a defasagem do Brasil em relação aos países desenvolvidos é a relativa escassez dos elementos essências à produção industrial moderna (capital e trabalho especializado), que contribui para baixos níveis de renda per capita e impedem países em desenvolvimento de realizar economias de escala (KRUGMAN; OBSTFELD, 2005, p.493).

Desse modo, o aumento da competitividade da indústria nacional, por meio da difusão do conhecimento e da produtividade, também deve ser considerada uma forma de promoção ao crescimento econômico e conseqüente desenvolvimento de um país. A difusão mais ampla do conhecimento tenderia a decrescer as diferenças de produtividade e, por conseguinte, trabalhar em prol de uma igualdade, melhorando-a (THERBORN, 2001). 
O aumento da competitividade das indústrias nacionais pode ser fortemente incentivado pela entrada de investimentos estrangeiros diretos direcionados à capacitação, tecnologia, planejamento e desenvolvimento (P\&D).

Os investimentos externos podem representar uma importante fonte alternativa de financiamento do desenvolvimento, principalmente se estiverem associados à criação de novas vantagens competitivas, a projetos de exportações e de substituição de importações e o aumento da capacidade de produção. (LACERDA, 2004b, p. 115)

Araújo Jr. (1996, p. 86) considera que "além dos investimentos em capital humano realizados no passado, os níveis de competitividade de uma economia dependem de uma estreita relação entre as estratégias adotadas pelos agentes privados e a conduta do governo". Assim, por um lado, o processo técnico mudou o funcionamento de mercados possibilitando associação entre empresas, e por outro, forçou os governos a abandonar as formas clássicas de protecionismo.

Jayme Jr. (2001) considera que uma alternativa para promover o crescimento econômico e, como conseqüência, aumentar o bem-estar da população e gerar desenvolvimento a um país, é o comércio internacional. Segundo o autor:

[...] uma síntese da teoria do comércio internacional tradicional está na tese de que o comércio internacional, excluindo-se o caso de distorções ou falhas de mercado, conduz a uma situação de maior bem-estar, comparativamente a uma situação de autarquia. Por isso, prescrições de política sugerem que a abertura é sempre a melhor alternativa, visto que políticas de liberalização comercial e de capitais são capazes de aumentar o bem-estar, num modelo estático de eficiência, ou estimular o crescimento econômico, num modelo dinâmico (JAYME JR., 2001, p. 72).

Ao avaliar os benefícios do comércio internacional, também é necessário analisar o papel das transnacionais nessa atividade. Nos últimos cinqüenta anos, o volume do comércio internacional cresceu sistematicamente mais rápido do que a produção mundial. Entretanto, neste período verificou-se internacionalmente uma transição, de uma época caracterizada pelo 
apogeu da regulação fordista ${ }^{1}$, com fronteiras nacionais parcialmente protegidas e mercados domésticos regulamentados, para uma época de liberalização e desregulamentação, em que o comércio é canalizado por transnacionais que organizam cada vez mais livremente o trabalho de suas filiais e suas relações de terceirização (CHESNAIS, 1996).

Se por um lado as transnacionais criam emprego e geram renda no país em que estão instaladas, por outro lado, grande parte dos lucros auferidos com o comércio internacional retorna ao país de origem, reduzindo os investimentos e o desenvolvimento no país em que se encontram. Esse é o caso de algumas empresas instaladas no Brasil que, a partir da década de noventa, modificaram sua estrutura acionária com os investimentos estrangeiros e privatizações, atuando internacionalmente sob orientação de matrizes no exterior.

\footnotetext{
${ }^{1} \mathrm{O}$ fordismo é um método de racionalização de produção em massa que surgiu com a indústria automobilística Ford, nos Estados Unidos. Através de um acordo, Ford dobrou o salário nominal dos funcionários, acabando com a alta rotatividade. Com a produtividade obtida na cadeia de montagem e a absorção de um contingente significativo de mão-de-obra no novo mercado de trabalho, melhor remunerado, conseguia-se não só obter uma produção de massa de baixo custo, mas também criar um mercado amplo capaz de consumir esta produção. Estabeleciam-se assim os dois princípios fundamentais do que se tornou posteriormente a Regulação Fordista da economia.
} 


\subsection{ESCOLHA DO TEMA}

A discussão sobre modelos de crescimento e desenvolvimento é recorrente no Brasil e amplamente explorada no mundo, dada à necessidade de promover desenvolvimento e principalmente eliminar a pobreza. Organizações internacionais, países e grupos de pesquisa buscam soluções através de reuniões, fóruns e atividades, tanto em âmbito nacional, quanto internacional. Uma das alternativas sugeridas e discutidas nesse esforço em buscar soluções é justamente estimular o comércio internacional, como forma de proporcionar o crescimento econômico e, conseqüentemente, o desenvolvimento econômico.

A relevância dessa abordagem proporcionou um grande número de discussões e publicações, tanto em livros e artigos, quanto em congressos e reuniões internacionais, facilitando e estimulando as discussões sobre o tema. Assim, a escolha desse tema, evidências de causalidade entre fluxos de capitais externos, crescimento e desenvolvimento econômico, se deu tanto pela crescente importância global, quanto pelo interesse pessoal em participar e colaborar com essa discussão.

\subsection{DEFINIÇÃO DO PROBLEMA DE PESQUISA}

O problema da pobreza é motivo de discussão em todo o mundo, e o que se acredita é que esse problema pode ser sanado através do desenvolvimento econômico. Freqüentemente se discute que o crescimento econômico é condição básica para o desenvolvimento econômico. Uma das alternativas sugeridas para gerar crescimento econômico (e, conseqüentemente, promover o desenvolvimento) se dá através do aumento das exportações e da entrada de 
investimento estrangeiro direcionado à modernização do parque industrial, estimulando a capacitação e aumentando a competitividade das indústrias, gerando empregos e renda. Assim, este trabalho busca responder a seguinte questão: Existe evidência de causalidade entre fluxos de capitais externos, crescimento econômico e desenvolvimento econômico no Brasil, no contexto da globalização (1990-2005)?

\subsection{OBJETIVOS}

Segundo Richardson (1999, p. 62) os objetivos de um trabalho científico devem ser extraídos do problema de pesquisa e são divididos em objetivo geral e objetivos específicos. De acordo com o autor, o objetivo geral define o que se pretende alcançar com a realização da pesquisa, e os objetivos específicos definem as etapas que devem ser cumpridas para alcançar o objetivo geral.

Assim, o objetivo geral deste trabalho é identificar se existe relação de causalidade entre fluxos de capitais externos, crescimento e desenvolvimento econômico no Brasil, no período de 1990 e 2005.

Como objetivos específicos, têm-se: (1) verificar a existência de causalidade de Granger entre fluxos de capitais externos, crescimento econômico e desenvolvimento econômico e (2) identificar a direção dos movimentos em caso de existência de causalidade. 


\subsection{ORGANIZAÇÃO DO TRABALHO}

Este trabalho está organizado em seções e subseções, da seguinte forma:

Na seção 1 é apresentada a introdução ao tema de pesquisa, abordando as premissas que levaram ao problema de pesquisa. Além da definição do problema de pesquisa, nessa seção estão especificados o objetivo geral do trabalho e os objetivos específicos para elucidação do problema de pesquisa.

Nas seções 2, 3 e 4 constam os temas da revisão bibliográfica: a seção 2 aborda o tema "Crescimento e Desenvolvimento Econômico"; a seção 3 aborda o tema "Fluxos Internacionais de Bens e Capitais"; os "Estudos Teóricos e Empíricos" são apresentados na seção 4. Como este trabalho é contextualizado no período de 1990 a 2005, a revisão bibliográfica sobre "Fluxos de Capitais Externos" é iniciada com o processo de "Globalização", abordando os conceitos e reflexões sobre o tema, além de considerar as principais implicações da abertura comercial para o mercado brasileiro, como as privatizações e a entrada de investimentos estrangeiros diretos. Em seguida, os temas abordados os Investimentos Estrangeiros Diretos (IEDs) e os aspectos relacionados ao comércio internacional. O fechamento da revisão teórica é feito com "Estudos Teóricos e Empíricos". Nessa seção são apresentados alguns estudos relacionando comércio internacional, crescimento e desenvolvimento econômico. Os principais autores desses estudos são MedinaSmith (2001) Jayme Jr. (2001) e Matos (2002 e 2003).

A seção 5 considera os procedimentos metodológicos para esse trabalho. Nessa seção são discutidos o método e a técnica escolhidos, além de informações sobre a obtenção das séries 
históricas e o tratamento de dados. Ainda nessa seção são detalhadas as técnicas econométricas para o estudo de causalidade utilizadas nesse trabalho.

A seção 6 está reservada para a apresentação e análise dos resultados: são apresentadas as saídas do softwares de análises estatísticas Eviews e SPSS e são discutidos os resultados do teste de causalidade de Granger entre as variáveis de crescimento, desenvolvimento e fluxos de capitais externos.

Na seção 7 são feitas as considerações finais e a conclusão do trabalho. Ao final do trabalho são inseridas as referências bibliográficas utilizadas no desenvolvimento desta dissertação. 


\section{CRESCIMENTO E DESENVOLVIMENTO ECONÔMICO}

A discussão sobre o tema é antiga, e seus conceitos estão adaptados para cada época e contexto. Dessa forma, para melhor entendimento do problema de pesquisa, e também para compreender e justificar as variáveis utilizadas nos procedimentos metodológicos, é necessária uma reflexão teórica abordando a evolução do pensamento econômico, os conceitos recentes e as reflexões dos economistas. Assim, esta seção é divida em três subseções.

A primeira subseção aborda a evolução do pensamento de acordo com sua época, analisando os principais pensadores e economistas com suas visões e considerações sobre o tema. Posteriormente são abordados nesta seção conceitos recentes e reflexões sobre o tema.

A segunda subseção é reservada para a discussão sobre os conceitos recentes sobre o tema. O primeiro conceito, discutido especialmente na década de 60, aborda as reflexões de Raúl Prebisch sobre a questão da dependência dos países periféricos. Outros conceitos mais recentes tratam das considerações de Douglas North, a abordagem de Joseph Stiglitz e o pensamento de Amartya Sen.

Finalmente, na terceira subseção, baseada na concepção Schumpeteriana da separação entre crescimento e desenvolvimento econômico, são inseridas observações e reflexões de diversos autores sobre o tema. 


\subsection{EVOLUÇÃO DO PENSAMENTO SOBRE CRESCIMENTO E DESENVOLVIMENTO}

A preocupação com o desenvolvimento é recorrente em nossa história. Os estudos sobre esse tema abordam as características e problemas de sua época respectiva. Os precursores dessa preocupação foram os mercantilistas e os fisiocratas, que dedicaram suas reflexões às causas da riqueza de uma nação (KRUGMAN, 2005).

Segundo os mercantilistas, a riqueza de uma nação estava baseada no afluxo de metais preciosos e na balança comercial favorável e, por isso, o Estado precisava interferir na economia e implementar políticas que gerassem acúmulo de metais preciosos, além de impulsionar o comércio internacional, provocando um maior crescimento econômico (GREMAUD et al, 2003). Os países buscavam um superávit comercial continuado, procurando maximizar o saldo da balança comercial por meio do aumento das exportações e da restrição das importações, dificultando, assim, o acesso de produtos importados similares em seu país. Com isso, o Estado mantinha uma postura protecionista e, ao impedir a livre concorrência, as empresas não tinham necessidade de se desenvolver e de se tornar competitivas, o que prejudicava o desenvolvimento interno.

Segundo Blanco et al (2004), David Hume, um dos críticos do mercantilismo, propôs que um superávit comercial continuado não era possível, nem desejável. Com o superávit, haveria transferência de metais preciosos e moedas metálicas para o país superavitário o que, ao invés de proporcionar desenvolvimento e crescimento, levaria a um aumento dos preços dos produtos produzidos domesticamente. Isso faria com que as exportações desse país ficassem relativamente mais caras no resto do mundo, reduzindo a procura delas no exterior (GONÇALVES et al, 1998). 
Um dos representantes dos fisiocratas, Quesnay $^{2}$, indicou como a agricultura fornece um produto líquido que se reparte entre as classes da sociedade, e admitiu ser a terra produtora da mais valia (GREMAUD et al, 2003). Para os fisiocratas, o aumento da produtividade, por meio da promoção da produção agrícola, poderia impulsionar o crescimento da economia. Segundo Quesnay, o comércio e a indústria, que apenas transformavam valores, não poderiam gerar o produto líquido.

Adam Smith, um dos principais representantes da escola clássica, abordou a questão do crescimento e do desenvolvimento com enfoque em finanças públicas, aumento do poder econômico e militar do monarca, sem se preocupar com a melhoria das condições de vida da população (GONÇALVES et al, 1998). De acordo com Smith (1996) a questão do desenvolvimento está na divisão do trabalho que, em termos modernos, seria a especialização da força de trabalho que acompanha o desenvolvimento econômico.

[...] o crescimento da produtividade do trabalho, que tem origem em mudanças na divisão e especialização do processo de trabalho, ao proporcionar o aumento do excedente sobre os salários permite $\mathrm{o}$ crescimento do estoque de capital, variável determinante do volume de emprego produtivo; a pressão da demanda por mão-de-obra sobre o mercado de trabalho, causada pelo processo de acumulação de capital, provoca um crescimento concomitante dos salários e, pela melhora das condições de vida dos trabalhadores, da população; o aumento paralelo do emprego, salários e população amplia o tamanho dos mercados que, para um dado estoque de capital, é o determinante básico da extensão da divisão do trabalho, iniciando-se assim a espiral de crescimento (FRITSCH ${ }^{3}, 1996$ in SMITH, 1996, p. 10)

Assim, com a divisão do trabalho haveria aumento de produtividade e, como consequiência, desenvolvimento. Como o trabalhador não poderia produzir todos os bens necessários à sua sobrevivência, produziria apenas aqueles para os quais possuísse habilidades ou recursos produtivos, o que o obrigaria a negociar e trocar um produto pelo outro (MUNHOZ, 2004).

\footnotetext{
${ }^{2}$ Não se referindo ao conceito de mais valia discutido por Marx (1996)

${ }^{3}$ FRITSCH, Winston - O autor fez a apresentação da reedição da obra de Smith (1996)
} 
[...] a riqueza ou o bem-estar das nações é identificado com seu produto anual per capita que, dada sua constelação de recursos naturais, é determinado pela produtividade do trabalho "útil" ou "produtivo" - que pode ser entendido como aquele que produz um excedente de valor sobre seu custo de reprodução - e pela relação entre o número de trabalhadores empregados produtivamente e a população total. (FRITSCH, 1996, p.9 in SMITH, 1996)

Dessa forma, a divisão do trabalho induziria à especialização e conseqüentemente à divisão internacional da produção. Segundo os princípios da divisão internacional da produção, cada país deveria produzir o que fosse economicamente mais conveniente e, por meio do comércio internacional, vender seus excedentes, diminuindo os custos e aumentando o bem estar social (MAIA, 2004).

O modelo teórico de desenvolvimento econômico de Smith constituía parte integrante de sua política econômica, pois, ao contestar o padrão mercantilista de regulamentação estatal e de controle, apoiava a suposição de que a concorrência maximiza o desenvolvimento econômico e de que os benefícios do desenvolvimento seriam partilhados por toda a sociedade (GREMAUD et al, 2003).

Thomas Malthus, David Ricardo e John Stuart Mill também refletiram sobre a questão do desenvolvimento (MUNHOZ, 2004, GREMAUD et al, 2003). Ao refletir sobre os possíveis prejuízos às condições de vida da sociedade, considerando o aumento populacional comparado ao de alimentos, Malthus subestimou o ritmo e o impacto do progresso tecnológico em benefício da população. Ricardo, em um primeiro momento, mostrou-se otimista em relação às conseqüências sociais do progresso tecnológico, o maquinismo, mas reviu sua posição e concluiu que a máquina poderia provocar o desemprego tecnológico e deteriorar as condições do trabalhador (GREMAUD et al, 2003). 
De acordo com Ricardo (1996), o grande problema do crescimento se encontrava na agricultura, incapaz de produzir alimentos suficientemente baratos. Apoiado na "teoria das vantagens comparativas", o autor afirma que cada país deveria especializar-se nas produções que apresentassem vantagens comparativas de custo, o que proporcionaria ganhos para todos os países envolvidos no comércio internacional.

[...] as trocas internacionais seriam vantajosas mesmo em uma situação em que um determinado país tivesse maior produtividade que o outro na produção de todas as mercadorias. [...] o comércio internacional sob condições de livre concorrência faria ambos os países especializarem-se na produção dos bens em que tinham maiores vantagens comparativas, e aumentaria o potencial de acumulação em ambos. (RICARDO, 1996, p. 11)

Mill introduziu na economia preocupações de justiça social e dedicou-se ao estudo da produção, distribuição da riqueza, troca de produtos e riquezas, influência do progresso técnico sobre a distribuição do produto entre capitalistas, trabalhadores e proprietários de terra, e influência da progressão sobre o governo (GREMAUD et al, 2003; MILL, 1996). Segundo Mill (1996), o aumento da produção pode resultar em crescimento demográfico, acumulação de capital ou inovações tecnológicas na produção e comércio de bens.

Para os neoclássicos o crescimento econômico geraria distribuição eqüitativa para todos os agentes econômicos de acordo com sua contribuição ao processo produtivo (MUNHOZ, 2004). Segundo Marshall (1996, p. 320), o progresso econômico das nações "pertence ao estudo do comércio internacional". Pareto também faz considerações sobre o comércio internacional:

[...] Ao demonstrar que o equilíbrio de uma economia em concorrência perfeita conduzia ao máximo de bem-estar da sociedade (primeiro teorema), Pareto tornou preciso o conceito clássico de "mão invisível": a capacidade de os agentes econômicos atingirem, de forma descentralizada e não intencional, o máximo de bem-estar da sociedade. Esse resultado fundamentou, por exemplo, a idéia de que o livre-comércio entre as nações levaria suas economias ao máximo de bem-estar social, defendida por 
expoentes da Economia Clássica como Adam Smith e Ricardo. (GARCIA ${ }^{4}$, 1996 in PARETO, 1996, p. 13)

Para esses economistas, o desenvolvimento era considerado um processo gradual, contínuo e harmonioso, derivado da acumulação de capital da poupança e taxa de juros, não sendo enfatizado a curto prazo.

[...] uma restrição moderada e temporária à acumulação de riqueza não será necessariamente um mal, mesmo de um puro ponto de vista econômico. Se levado a efeito paulatinamente e sem perturbações, proporciona melhores oportunidades à grande massa da população, aumenta sua eficiência e desenvolve nela os hábitos de que resulta o crescimento de uma raça muito mais eficiente de produtores na geração seguinte. Desse modo, pode-se promover muito melhor, afinal de contas, o desenvolvimento mesmo da riqueza material do que pela multiplicação do número de fábricas e máquinas a vapor. (MARSHALL, 1996, p.40)

Por um outro prisma, o economista alemão Karl Marx analisou o crescimento econômico capitalista e seu funcionamento, preocupando-se com as conseqüências sociais da industrialização (GREMAUD et al, 2003). Segundo Marx (1996), no processo de crescimento econômico capitalista, a evolução tecnológica gerava crescimento do capital e essa acumulação de capital era responsável pela elevação da produtividade e da mais valia, expandindo o exército industrial de reserva, empobrecendo a maioria da população e diminuindo o ritmo de consumo global. Para Marx (1996, p. 169):

[...] a força produtiva do trabalho é determinada por meio de circunstâncias diversas, entre outras, pelo grau médio de habilidade dos trabalhadores, o nível de desenvolvimento da ciência e sua aplicabilidade tecnológica, a combinação social do processo de produção, o volume e a eficácia dos meios de produção e as condições naturais.

Schumpeter (1996) aborda o tema separando desenvolvimento e crescimento econômico, pois, para o autor, desenvolvimento consistia nas mudanças da vida econômica que não eram impostas de fora, enquanto crescimento econômico, demonstrado pelo crescimento da população e riqueza, não suscitava qualquer fenômeno novo. O autor destaca a inovação

\footnotetext{
${ }^{4}$ GARCIA, Fernando - O autor fez a apresentação da reedição da obra de Pareto (1996)
} 
empresarial como a principal força para o crescimento econômico e ainda discute as funções do crédito e do capital no desenvolvimento econômico.

A concentração de riquezas, o desenvolvimento de alguns países mais industrializados e a ausência de desenvolvimento por parte de outros países no fim do século XIX levaram pesquisadores a refletir a noção de desenvolvimento e a relação com a distribuição de renda. Dessa forma, os neoclássicos, passaram a se preocupar com a alocação dos recursos escassos entre usos alternativos, com o fim de maximizar a utilidade ou a satisfação dos consumidores (GREMAUD et al, 2003).

No contexto da Grande Depressão, os economistas perceberam que a ciência clássica não lhes permitia analisar integralmente a expansão da atividade econômica e elaborar políticas econômicas adequadas (GREMAUD et al, 2003). Como alternativa à Grande Depressão, Keynes (1996) defendeu o desenvolvimento sustentado pelo Estado, focando suas reflexões no pleno emprego, fatores do crescimento do investimento e impactos sobre a renda e emprego.

\subsection{CONCEITOS RECENTES SOBRE CRESCIMENTO E DESENVOLVIMENTO}

Com o fim da Segunda Guerra Mundial a Europa e o Japão estavam destruídos. Os países precisavam reerguer suas indústrias, produzir, gerar emprego e renda e com isso promover crescimento econômico. Como as economias dos países estavam parcialmente destruídas, havia importação de produtos de países estrangeiros (MAIA, 2004). Contudo, havia um 
sentimento de protecionismo em toda a Europa, pois se os países importassem produtos estrangeiros, a indústria interna não se desenvolveria.

Dessa forma, ao substituir as importações por produtos nacionais, os países estimulavam a indústria nacional a se desenvolver. Apesar dos acordos sobre tarifas e comércio, esse protecionismo ocorreu por meio de barreiras tarifárias e não tarifárias, e esse sentimento foi partilhado por diversos países no mundo.

Assim, desde o fim da Segunda Guerra até a década de 70, muitos países adotaram o modelo de industrialização pela substituição de importações. Esse modelo, conhecido como Processo de Substituição de Importações (PSI), foi empregado em países como o Brasil, e apregoado pela Comissão Econômica para a América Latina e o Caribe (CEPAL) como sendo um elemento importante para o desenvolvimento de economias menos desenvolvidas (PEREIRA, 2003).

[...] Por cerca de 30 anos após a Segunda Guerra Mundial, as políticas comerciais em muitos países em desenvolvimento foram intensamente influenciadas pela crença de que a chave para o desenvolvimento era criar um forte setor manufatureiro, e que a melhor maneira de criar tal setor era protegendo os manufatureiros domésticos da concorrência internacional. (KRUGMAN, 2005, p. 191)

$\mathrm{Na}$ América Latina, a CEPAL realizou estudos sobre os países latino-americanos, apresentando o conceito de centro-periferia, defendido por Prebisch $(1950,1963)$. Baseado no conceito centro-periferia, Prebisch (1950) e Singer (1950) apresentaram a teoria da deterioração dos termos de troca, em que os países periféricos, produtores de matérias-primas de menor valor agregado, ficariam sempre dependentes dos países centrais, produtores de bens industrializados. Para Soares (2004), a tese de Prebisch parte da constatação empírica de que os países subdesenvolvidos são exportadores primários enquanto os países desenvolvidos obtêm sua renda de exportação de produtos manufaturados. 
A questão do crescimento de nações subdesenvolvidas tornou-se o foco das preocupações dos países centrais, quer seja por razões políticas ou por razões humanitárias (BHAGWATI, 1975). O autor ainda complementa que os países subdesenvolvidos sofreram um adverso declínio em longo prazo, nos termos em que trocaram suas exportações por importações. Soares (2004) considera que os produtos primários, exportados pelos países subdesenvolvidos, têm elasticidade-preço baixa, decorrente do progresso técnico dos países desenvolvidos, o que os desfavorece. Para Prebisch (1963, p. 102):

[...] do ponto de visto da relação de preços, as diferenças fundamentais são as seguintes: Antes de mais nada, o caráter essencialmente industrial das exportações dos centros. Os produtos industriais têm, via de regra, uma elasticidade renda da procura muito elevada, e tão logo esta tende a saturarse, com o correr do tempo, no tocante a alguns artigos, surgem outros novos, ou novas formas para os artigos já existentes, que reavivam continuamente a procura industrial. Há deslocamentos de mão de obra para indústria, mas a atividade industrial absorve, no seu conjunto, uma proporção crescente do incremento de população ativa, pelo menos até um certo limite, para lá do qual esta função se transfere progressivamente para outras atividades absorventes. Na produção primária, ocorre precisamente o contrário, e, à medida que cresce, com relativa lentidão, a procura dos artigos existentes, só excepcionalmente surgem novos artigos ou novas variedades e, mesmo assim, isso não acontece com a amplidão necessária para contrabalançar a tendência da mão de obra para se deslocar para atividades urbanas [...].

Prebisch criticou a visão Ricardiana de que cada país deveria se especializar nas produções que apresentassem vantagens comparativas de custo, pois a teoria de Ricardo não considera a evolução da demanda à medida que as economias se desenvolvem e seu nível de renda cresce (GREMAUD; VASCONCELlOS; TONETO JR., 2002). Pela teoria das Vantagens Comparativas, a América Latina deveria produzir alimentos e matérias primas para exportação, e importar produtos industrializados. Por essa visão, os países subdesenvolvidos não necessitariam de se industrializar, uma vez que teriam os benefícios das trocas com países que produziriam a baixos custos (vantagem comparativa de custo). 
Esse fenômeno resultaria na dependência da América Latina dos produtos industrializados dos países centrais, perpetuando o subdesenvolvimento e as diferenças econômico-sociais nos países periféricos. Prebisch (1963) propôs a industrialização como núcleo da política de desenvolvimento, procurando diversificar mercados e, com isso, elevando o nível de renda da população, uma vez que o aumento da demanda por produtos aumentaria a necessidade de mão de obra nas indústrias, e a renda gerada por esses trabalhadores aqueceria o comércio, fechando um ciclo de desenvolvimento. O desenvolvimento de tecnologia aumentaria o nível de produção e o aumento da produtividade e renda permitiria a acumulação de capital.

Nesse contexto de protecionismo e dependência, os países subdesenvolvidos passaram a reivindicar maior ajuda dos países desenvolvidos (MUNHOZ, 2004). Para os pesquisadores, o novo enfoque das pesquisas foi o questionamento dos fatores que causavam o subdesenvolvimento. Os estudos foram realizados para diagnosticar os obstáculos ao desenvolvimento e estudos sobre o crescimento dos países.

Após duas décadas de relativo abandono, ressurgiram estudos sobre o crescimento econômico na segunda metade dos anos 80 . Com a aceleração do processo de globalização ocorrido na década de 90, o tema voltou a ser objeto de discussão, quando o crescimento econômico alcançou altos níveis, tanto em países desenvolvidos quanto em países em desenvolvimento, especialmente do Leste Asiático (MATOS, 2003).

A globalização passou a ser estudada sob a ótica do desenvolvimento, avaliando seus efeitos sobre a melhoria da qualidade de vida da população. Para Streeten (2001), a globalização foi boa para o Japão, Europa, América do Norte, Leste e Sudeste Asiático, em detrimento dos 
países em desenvolvimento na África e América Latina, com exceção das ilhas Maurício, Botswana, Chile e Costa Rica.

Ao mesmo tempo que a reestruturação econômica, a liberalização, as mudanças tecnológicas e a competição feroz que acompanharam a globalização, tanto no mercado de bens quanto no de mão de obra, contribuíram para aumentar o empobrecimento, a desigualdade, a insegurança no trabalho, o enfraquecimento das instituições, dos sistemas de apoio social, o desgaste da identidade e dos valores estabelecidos. A liberalização e a diminuição da proteção à agricultura, reduzindo o fornecimento agrícola, fizeram subir o preço dos alimentos, aumentando o sofrimento dos países importadores de gêneros alimentícios (STREETEN, 2001, p. 72)

Os países asiáticos, conhecidos como economias asiáticas de alto desempenho (EAADs), atingiram um crescimento econômico de $10 \%$ ao ano, baseadas no livre comércio e política econômica não intervencionista (KRUGMAN, 2005). Segundo Krugman (2005), o sucesso desses países se deu graças às medidas que favoreceram indústrias por meio de políticas de fomento à exportação, como tarifas e restrições à importação, subsídios à exportação, empréstimos a juros baixos e apoio do governo em pesquisas e desenvolvimento.

Como medida de comparação, a relação entre exportação e o PIB desses países é bastante alta, em especial quando comparada com os países da América Latina e Sul da Ásia. Um exemplo dessas economias asiáticas de alto desempenho são os Tigres Asiáticos. Segundo Mankiw (1998), além do ganho em produtividade, que é contestado em alguns trabalhos, esses países apresentam mudanças em vários indicadores, como a relação entre investimento e PIB, acréscimos no estoque de capital, participação da força de trabalho e melhoria do grau de instrução (percentual da população economicamente ativa com grau de instrução igual ou superior ao $2^{\circ}$ grau).

A seguir, no gráfico 2.1, são apresentados os dados de comparação entre o crescimento médio do PIB (entre os anos de 1990 e 2001) e a relação entre exportação e PIB (coeficiente de 
exportação) do Brasil e Tigres Asiáticos (exceto Hong Kong) em 2001. Pode-se notar que o Brasil apresenta um menor crescimento médio do PIB entre 1990 e 2001 quando comparado aos Tigres Asiáticos, assim como o coeficiente de exportação.

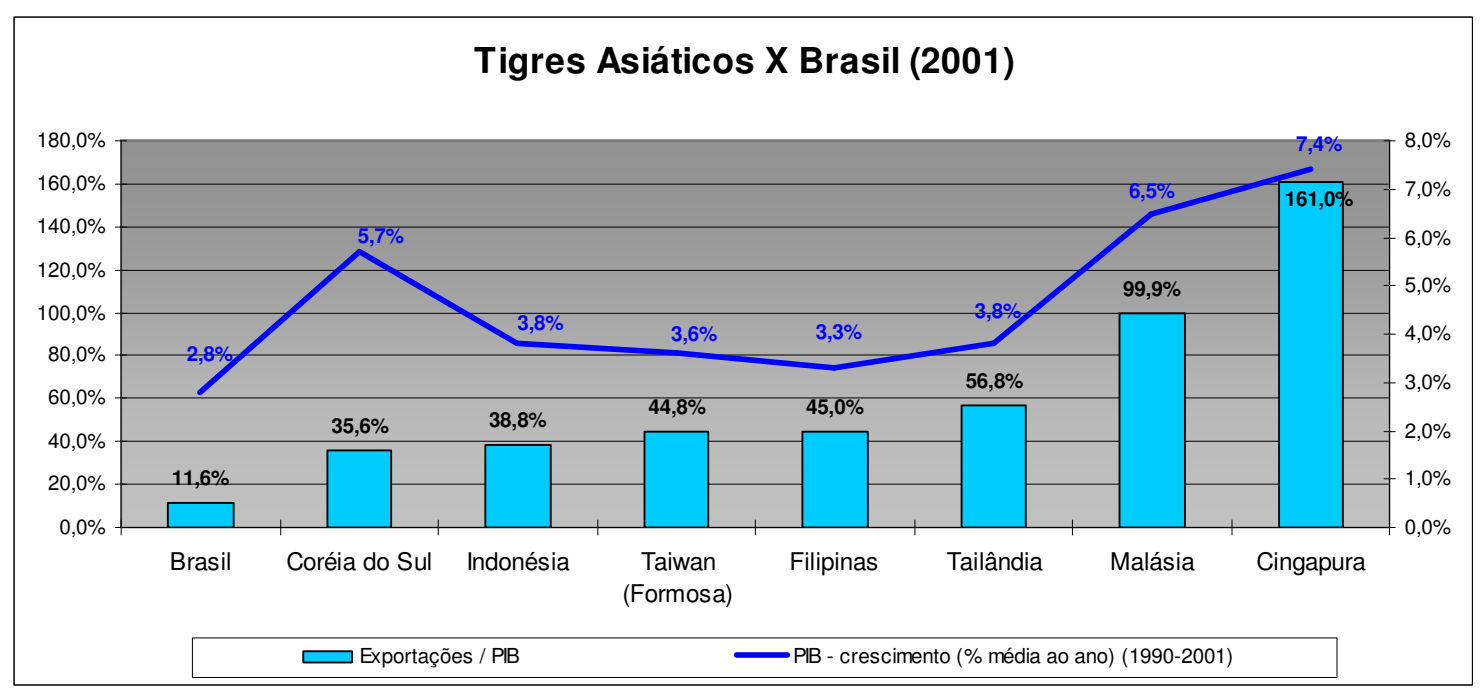

Gráfico 2.1 - Coeficiente de Exportação e crescimento do PIB - Tigres Asiáticos X Brasil

Esse modelo de crescimento dos países em desenvolvimento preocupou os países desenvolvidos à medida que os primeiros (países periféricos) combinavam alta produtividade e baixos salários, ameaçando a manutenção do padrão nos países centrais (KRUGMAN, 1997; KRUGMAN, 2005). O crescimento econômico acelerado e o desenvolvimento proporcionado pela exportação permitiram o aumento do nível de renda para muitos países em desenvolvimento, porém os indicadores sociais (nível de vida, acesso à educação, índice de mortalidade, dentre outros) não acompanharam essa mesma evolução.

Contudo, o modelo de desenvolvimento adotado por esses países emergentes não era totalmente imune a grandes períodos de crise. As grandes crises econômicas da década de 90 trouxeram recessão para os países em desenvolvimento (KRUGMAN, 2001). 
As recentes crises financeiras ocorridas nos mercados emergentes compartilham com as seguintes características: (1) elas foram precedidas por grandes fluxos de entradas de capitais; (2) desenvolveram-se através de uma complicada interação entre setores financeiros, domésticos e não-financeiros, investidores e bancos internacionais e governos soberanos; (3) poucas pessoas foram capazes de prevê-las; (4) elas levaram a uma acentuada redução do crescimento econômico, quase levando a um colapso da produção (CALVO, 2001, p. 77)

No Brasil, assim como na América Latina, três questões fundamentais balizam o debate sobre as perspectivas de desenvolvimento: (1) as nações latino-americanas se distinguem da Ásia por uma dependência muito mais elevada com relação a recursos financeiros do exterior, sobretudo financiamentos e empréstimos; (2) a necessidade de políticas de distribuição de riqueza e renda, considerando que os países latino-americanos apresentam maior concentração de renda que os países da Ásia, ameaçando o próprio crescimento econômico e; (3) a tarefa dos governos latino-americanos em assegurar melhor qualidade das políticas macroeconômicas, principiando maior estabilidade (RICUPERO, 2001a).

As economias latino-americanas foram marcadas por desigualdades na distribuição de renda e pela pobreza (CHESNAIS, 1998). No Brasil, historicamente nota-se evolução positiva da produção per capita, contudo ao ser comparado com países desenvolvidos, apresenta níveis baixos de PIB per capita (CHESNAIS, 1998). Até a década de 80, a não ser em algumas poucas oportunidades, o PIB per capita brasileiro cresceu a taxas bastante razoáveis (GREMAUD; VASCONCELLOS; TONETO JR., 2002).

Apesar do Plano Real, o crescimento econômico brasileiro continuou inexpressivo. Medido através do Produto Interno Bruto (PIB), o crescimento verificado entre 1990 e 2003 ficou abaixo da média mundial e a renda per capita apresentou estagnação entre 1990 e 2003 (CORDEIRO, 2005). O PIB apresentou períodos de alta entre 1993 e 1995 e períodos de baixa durante o governo Collor (1990-1992), Crise do México (1995), Crise Russa (1998), 
crise cambial (1999-2000), Crise Argentina (2001), racionamento e instabilidade política das eleições (2001-2002). O baixo crescimento da renda per capita limitou o crescimento do mercado interno e por conseqüência dificultou a melhoria do padrão de vida da população.

Atualmente há três principais correntes na análise acadêmica do desenvolvimento: o novo institucionalismo, que tem como principal colaborador Douglass North, as relações entre renda, produtividade e desenvolvimento defendidas por Joseph Stiglitz e as reflexões sobre liberdade, de Amartya Sen (MUNHOZ, 2004; ABRAMOVAY, 2001).

North (1990) discute a influência das instituições no desenvolvimento da sociedade. O autor defende que o desenvolvimento dos países menos desenvolvidos pode ser explicado pela ineficiência de suas instituições, por meio de análise dos custos de transação, das restrições e coerções, e do aprendizado, o que impede a acumulação de capital e conhecimento. Segundo North (1990) os fatores que explicam o crescimento econômico sustentado não são a capacidade inovadora, a democratização do ensino e a valorização do conhecimento, e sim um reflexo da eficiência das instituições.

Para Abramovay (2001), o que caracteriza o subdesenvolvimento é o conjunto de instituições, isto é, de regras do jogo, de normas e valores que orientam a conduta do dia-a-dia, de orientações que reduzem a incerteza dos indivíduos, que dissociam o trabalho do conhecimento, que dificultam o acesso à terra e bloqueiam a inovação. Uma sociedade que concentra as oportunidades de geração de renda e os ativos, dificilmente consegue transmitir aos seus cidadãos a confiança necessária a que se formem as estruturas de cooperação capazes de valorizar de maneira generalizada as atividades produtivas (ABRAMOVAY, 2001). 
Stiglitz relaciona produtividade e renda com condições e indicadores de desenvolvimento. De acordo com Stiglitz e Walsh (2003, p. 404), a "baixa ou nenhuma escolaridade, desnutrição e atendimento precário à saúde reduzem a produtividade e, conseqüentemente, a renda" formando um ciclo vicioso, pois "dada a renda baixa, a população dos países menos desenvolvidos não consegue ter acesso a melhor instrução, mais alimentos ou melhor assistência à saúde". Os autores ainda consideram que as altas taxas de crescimento populacional interferem nos indicadores de desenvolvimento, aumentando a dependência de crianças e adolescentes de terceiros em termos de renda.

Sen (2002) desenvolveu estudos sobre o bem-estar econômico, refletindo sobre os mecanismos causadores da fome e pobreza. O autor analisou o desenvolvimento como a eliminação de privação de liberdade (pobreza, tirania, falta de oportunidades econômicas, destituição social sistemática, negligência dos serviços públicos e intolerância de Estados opressivos), que limitam as escolhas e as oportunidades de as pessoas exercerem de forma ponderada sua condição de indivíduo (SEN, 2002).

Para Sen, "o combate de tais problemas exige que a liberdade individual seja considerada um comprometimento social" (VEIGA, 2005). Veiga (2005) considera que o crescimento econômico pode ser um meio de expandir as liberdades desfrutadas pelos membros de uma sociedade, mas as liberdades dependem de outros determinantes, como saúde, educação e direitos civis.

Para Abramovay (2001), as sociedades enfrentam um dilema entre eqüidade e eficiência: o crescimento, ou seja, a utilização eficiente de recursos, supõe poupança e, portanto, uma certa 
concentração que forçosamente sacrifica a igualdade. Embora o crescimento inicialmente não tolere excessos na distribuição, ele é fundamental no combate à pobreza.

A eficiência conseguida pelas contínuas inovações tecnológicas e o acúmulo de capital proporcionado pelo capitalismo promoveram grandes alterações na estrutura das sociedades. A exemplo disso, no século XX a produção industrial cresceu de 30 a 40 vezes, e a população mundial dobrou, permitindo um incremento na produção per capita.

Segundo Gremaud et al (2003), para que uma sociedade cresça é necessária (1) a acumulação de capital, por meio de máquinas, indústrias, obras de infra-estrutura e investimentos em recursos humanos; (2) o crescimento da população, implicando aumento da forca de trabalho e demanda interna e; (3) o progresso tecnológico.

A evolução da teoria do crescimento econômico mostrou que, a inserção de variáveis como capital humano, tecnologia e inovação na função de produção trouxe um melhor arcabouço teórico e científico, visando entender e quantificar a posteriori a evolução do Produto Interno Bruto (PIB) dos países ao longo do tempo, isto é, do modelo original, onde constavam as variáveis capital e trabalho, podem-se aferir, atualmente capital físico, capital humano, trabalho e tecnologia/inovação. (PEREIRA, 2003, p. 197)

Pereira (2003) acrescenta que para se obter um crescimento econômico de longa maturação e bem alicerçado, a estrutura econômica de um país deve primar pela conjunção de políticas institucionais e econômicas auto-sustentáveis de longo prazo. "A manutenção da estabilidade econômica e a retomada do desenvolvimento auto-sustentável deveria passar pela modernização do parque industrial, visando o aumento da produtividade e resolução definitiva do problema fiscal brasileiro" (CORDEIRO, 2005, p.119). 
Segundo Cordeiro (2005), seriam necessárias reformas para viabilizar os objetivos: (a) abertura da economia local, proporcionada pela abertura comercial, abertura do mercado local de capitais, supressão de restrições ao ingresso de capital estrangeiro e desregulamentação e (b) diminuição do déficit orçamentário e redução do estoque da dívida pública, por meio da privatização de empresas públicas, reforma previdenciária, reforma tributária e reforma administrativa. 


\subsection{REFLEXÕES SOBRE CRESCIMENTO E DESENVOLVIMENTO}

Segundo Mankiw (2005, p. 502), o Produto Interno Bruto (PIB) é uma medida de bem-estar econômico e pode ser definido como "o valor de mercado de todos os bens e serviços finais produzidos em um país em dado período de tempo". Para o autor, o PIB mede duas coisas ao mesmo tempo: a renda total de todas as pessoas da economia e a despesa total com os bens e serviços produzidos na economia.

Por não medir aspectos relacionados à saúde, educação e distribuição de renda, o PIB é contestado como medida perfeita de bem-estar. Sob este aspecto são discutidas as diferenças entre crescimento e desenvolvimento econômico (MANKIW, 2005).

Desenvolvimento econômico apresenta diferentes conceitos segundo autores. O tema emergiu somente no século XX em decorrência das flutuações econômicas do século XIX e da concentração de renda e riqueza, agravada pelo surgimento de alguns países industrializados (SOUZA, 2005). O autor ainda destaca duas correntes sobre desenvolvimento. A primeira corrente, defendida por modelos de crescimento de tradição neoclássica e keynesiana, considera crescimento como sinônimo de desenvolvimento. A segunda corrente entende que o crescimento é condição indispensável para o desenvolvimento, porém não suficiente. 


\subsubsection{CRESCIMENTO ECONÔMICO}

É consensual que o crescimento econômico é medido através do PIB. A equação para seu cálculo é dada por:

$Y=C+I+G+E L$

em que $\mathbf{Y}$ é o Produto Interno Bruto; $\mathbf{C}$ é o Consumo (despesas das famílias em bens e serviços); I é o Investimento (compra de bens que serão utilizados no futuro para produzir bens e serviços); G são as Compras do Governo (despesas em bens e serviços dos governos locais, estaduais e federal); e EL são sas Exportações Líquidas (exportações menos importações).

O crescimento econômico, medido através do aumento do PIB, pode ser obtido pelo aumento da produção interna, através do aumento de produtividade e competitividade, e também pelo comércio internacional, através da exportação dos produtos e serviços. Assim, alguns fatores que proporcionam o aumento da produtividade e competitividade, como investimentos externos direcionados às indústrias e as exportações, podem estar diretamente relacionados com o crescimento econômico.

Gremaud et al (2003, p. 485), conceitua crescimento econômico como "o aumento contínuo do produto interno bruto em termos globais e per capita, ao longo do tempo". Kuznets (1971) considera que a capacidade de crescimento econômico, baseada no avanço tecnológico exige ajustes institucionais e ideológicos. 
Pereira (2003), ao analisar a estrutura do pensamento econômico relacionado ao crescimento e à inovação e tecnologia, apresenta nove grandes grupos. Na tabela 2.1 são apresentados os grupos, os principais autores e os temas abordados sugeridos no trabalho de Pereira (2003).

\begin{tabular}{|c|c|c|}
\hline Grupos & Autores & Abordagem \\
\hline Grupo 1 & $\begin{array}{l}\text { Adam Smith (1776) } \\
\text { David Ricardo (1817) } \\
\text { Thomas Malthus (1798) }\end{array}$ & $\begin{array}{l}\text { Abordam temas sobre tamanho de mercado, acumulação } \\
\text { de capital físico e divisão do trabalho; rendimentos } \\
\text { decrescentes e estado estacionário - papel da tecnologia e } \\
\text { do salário de subsistência regulado pelo mecanismo } \\
\text { malthusiano. }\end{array}$ \\
\hline Grupo 2 & $\begin{array}{l}\text { Frank Ramsey (1928) } \\
\text { Frank Knight (1944) } \\
\text { J. Schumpeter (1934) }\end{array}$ & $\begin{array}{l}\text { Análises sobre otimização intertemporal de utilidade pelas } \\
\text { unidades e agregação dos componentes individuais, } \\
\text { retornos não decrescentes ao capital humano e inovação. }\end{array}$ \\
\hline Grupo 3 & $\begin{array}{l}\text { J. Keynes } \\
\text { Roy Harrod (1939) } \\
\text { Evsey Domar (1946) } \\
\text { Kaldor (1955 } \\
\text { Pasinetti (1962) }\end{array}$ & $\begin{array}{l}\text { A taxa de crescimento da renda e dos investimentos } \\
\text { dependem diretamente da propensão a poupar e, } \\
\text { inversamente, da relação produto-capital (Modelo Harrod- } \\
\text { Domar). Análise da taxa de poupança e da distribuição } \\
\text { funcional da renda como mecanismo de ajuste ao longo do } \\
\text { ciclo. }\end{array}$ \\
\hline Grupo 4 & $\begin{array}{l}\text { Solow } \\
\text { Swan }\end{array}$ & $\begin{array}{l}\text { Ajustamento automático ao crescimento equilibrado via } \\
\text { flexibilidade tecnológica, a convergência de níveis de } \\
\text { riqueza para dado padrão tecnológico, a necessidade do } \\
\text { progresso técnico para explicar acumulação de riquezas. }\end{array}$ \\
\hline Grupo 5 & $\begin{array}{l}\text { Cass } \\
\text { Koopmans }\end{array}$ & $\begin{array}{l}\text { Endogeneizou a taxa de poupança e incorporou a } \\
\text { otimização intertemporal ao modelo neoclássico. } \\
\text { Tecnologia como variável mais estudada }\end{array}$ \\
\hline Grupo 6 & $\begin{array}{l}\text { Arrow (1962) } \\
\text { Sheshinski (1967) }\end{array}$ & $\begin{array}{l}\text { A partir de Arrow e Sheshinksi surgiu a formulação } \\
\text { moderna do learning by doing por um período de } 15 \text { anos. }\end{array}$ \\
\hline Grupo 7 & $\begin{array}{l}\text { Romer (1986) } \\
\text { Lucas (1988) }\end{array}$ & $\begin{array}{l}\text { Posteriormente surgiram contribuições de Romer e Lucas, } \\
\text { considerando o progresso técnico endógeno e a } \\
\text { incorporação do learning by doing, capital humano e } \\
\text { externalidades. }\end{array}$ \\
\hline Grupo 8 & Scherer (1999) & $\begin{array}{l}\text { Avalia que um grande passo para as novas teorias de } \\
\text { crescimento econômico é considerar que o capital físico } \\
\text { não era o único tipo usado na produção. Valoriza o capital } \\
\text { humano, baseado em habilidades, treinamento e educação. }\end{array}$ \\
\hline Grupo 9 & $\begin{array}{l}\text { Romer (1987, 1990) } \\
\text { Aghion e Howitt (1992) } \\
\text { Grossman e Helpman (1991) }\end{array}$ & $\begin{array}{l}\text { Inseriram a incorporação da pesquisa e do } \\
\text { desenvolvimento, a concorrência imperfeita nos modelos, } \\
\text { o governo e o progresso técnico. }\end{array}$ \\
\hline
\end{tabular}

Quadro 2.1 - Crescimento Econômico e Inovação Tecnológica

Para Lopes e Vasconcellos (2000), os dois principais modelos que determinam o crescimento no produto a longo prazo são os modelos Harrod-Domar e Solow. 
O modelo Harrod-Domar considera que o desenvolvimento econômico é um processo gradual e equilibrado, em que são destacadas três variáveis básicas para o crescimento: a taxa de investimento, a taxa de poupança e a relação produto-capital. Segundo o modelo, o investimento agregado apresenta na economia o efeito demanda (aumento do investimento que resulta em aumento da demanda pelo produto) e o efeito capacidade (investimentos aumentam a capacidade da economia em elaborar o produto).

Considerando esses dois efeitos, tem-se um problema: se a cada período ocorrem investimentos, no período seguinte tem-se um aumento da capacidade produtiva. Tal efeito pode resultar em um aumento da capacidade ociosa. Para que isso não aconteça, deve ocorrer um equilíbrio entre os dois efeitos.[...] Ou seja, a taxa de crescimento do investimento líquido e a do produto devem ser iguais à propensão marginal a poupar multiplicada pela produtividade do capital (Lopes; Vasconcellos, 2000, pp. 286-287).

O modelo Solow atribui o crescimento econômico à acumulação de capital, ao crescimento da força de trabalho e às alterações tecnológicas (LOPES; VASCONCELLOS, 2000). O modelo segue a seguinte função de produção:

$\mathrm{Y}=\mathrm{F}(\mathrm{K}, \mathrm{N}, \mathrm{T})$

em que $\mathbf{Y}$ é o produto; $\mathbf{K}$ é o estoque de capital; $\mathbf{N}$ é a mão de obra e $\mathbf{T}$ é a tecnologia. De acordo com Lopes e Vasconcellos (2000), considerando que as mudanças tecnológicas (T) causam igual aumento no produto marginal de $\mathbf{K}$ e $\mathbf{N}$, a função de produção pode ser reescrita da seguinte forma:

$\mathrm{Y}=\mathrm{T} \cdot \mathrm{F}(\mathrm{K}, \mathrm{N})$

em que $\mathbf{F}(\mathbf{K}, \mathbf{N})$ representa a função de produção neoclássica. Nesse modelo, o estoque de capital é influenciado pela taxa de poupança, de forma que um aumento nessa taxa eleva os 
investimentos e, em longo prazo, o estoque de capital também será elevado (LOPES; VASCONCELLOS, 2000). "Dessa forma a taxa de poupança da economia determina a quantidade de seu estoque de capital e, portanto seu nível de produção” (MANKIW, 1998, p. 86).

Com relação ao crescimento populacional, seu aumento resulta em uma redução do estoque de capital por trabalhador. Assim, economias que possuem altas taxas de crescimento populacional tendem a apresentar baixos níveis de estoques de capital e, por conseqüência, produtos e renda mais baixos (MANKIW, 1998 e LOPES; VASCONCELLOS, 2000).

Segundo Stiglitz e Walsh (2003) e Mankiw (2005), as grandes variações dos padrões de vida por todo o mundo são explicadas pela produtividade. A produtividade refere-se à quantidade de bens e serviços que um trabalhador pode produzir por cada hora de trabalho. Partindo do princípio de que a renda de uma economia equivale à sua produção, tem-se de maneira simplificada que quanto maior for a produtividade, maiores serão as chances de aumento de renda e, com isso, melhor será o padrão de vida da população.

A produtividade é determinada por diversos fatores. Para Mankiw (2005), é determinada pelo capital humano (conhecimento e habilidades que os trabalhadores adquirem por meio de educação, treinamento e experiência), recursos naturais (insumos produzidos pela natureza), conhecimento tecnológico (melhores maneiras de produzir bens e serviços) e capital físico (estoque de equipamentos e estruturas usado para produzir bens e serviços). Stiglitz e Walsh (2003) ainda consideram a poupança, investimentos e realocação de recursos de setores de baixa produtividade como fatores que determinam a produtividade. 
Para Stiglitz e Walsh (2003), o capital humano altamente qualificado pode ser uma grande fonte de aumento de produtividade. Essa qualificação é conseguida através de treinamentos e educação. "Essas despesas são investimentos - tal como investimentos em máquinas e instalações. E do mesmo modo que esses gastos resultam na criação do capital físico, dizemos que as despesas com educação criam o capital humano" (STIGLITZ; WALSH, 2003, p. 191). O capital humano é importante para o crescimento econômico porque propaga externalidades positivas. Dessa forma, uma pessoa instruída pode gerar novas idéias sobre a melhor forma de produzir bens e serviços (MANKIW, 2005). Da mesma forma, os recursos naturais também são importantes para o crescimento econômico uma vez que podem restringir a produção. Malthus analisou essa questão sobre o prisma do crescimento da população. Em teorias modernas, a acumulação de capital é analisada em relação a esse crescimento.

O avanço tecnológico é a principal razão pela qual os padrões de vida são cada vez mais elevados (Mankiw, 2005). Segundo Rocha e Ferreira (2001, p. 65), “o processo de inovação tecnológica passa a dominar as discussões sobre estratégia de inserção internacional de empresas e países, pela importância que vem assumindo enquanto fator determinante da competitividade e mesmo sobrevivência das empresas". Através de pesquisa e desenvolvimento, empresas podem desenvolver tecnologias e se tornarem competitivas. Um dos indicadores do desenvolvimento de tecnologia é o pagamento ou recebimento de royalties.

Segundo Mankiw (2005), uma maneira de aumentar a produtividade futura é investir mais recursos correntes na produção de capital físico. Para Stiglitz e Walsh (2003, p. 191), maiores níveis de investimento em relação ao PIB resultam em mais capital por trabalhador. Para que uma sociedade invista mais em capital, ela deve consumir menos e poupar mais de sua renda 
corrente. Assim, o crescimento que decorre da acumulação de capital exige que a sociedade sacrifique o consumo de bens no presente para desfrutar maior consumo no futuro. Entretanto:

[...] no longo prazo, uma maior taxa de poupança leva a um maior nível de produtividade e renda, mas não a um maior crescimento dessas variáveis. [...] Os trabalhadores de países ricos têm uma grande quantidade de capital à sua disposição, e isso explica, em parte, sua alta produtividade. Mas se a quantidade de capital por trabalhador já é tão elevada, investimentos adicionais de capital tem efeito relativamente pequeno sobre a produtividade. Estudos de dados internacionais sobre crescimento econômico confirmam o efeito de alcance: controlando as demais variáveis, tais como o percentual do PIB destinado ao investimento, os países pobres tendem a crescer a um ritmo mais rápido do que os países ricos. (MANKIW, 2005, pp. 546-547)

Para Gonçalves (1996, p. 157), “a expansão dos fluxos internacionais de capitais nos anos 90, permitiu a várias economias em desenvolvimento o aumento dos investimentos domésticos, vis-a-vis a poupança interna, por meio do financiamento do saldo negativo da conta de transações correntes". Segundo o autor, a poupança externa foi fundamental para as taxas de crescimento de renda nos países em desenvolvimento. No Brasil, a relação entre a poupança e o PIB é baixa. Com a baixa poupança, os investimentos não são direcionados para o capital e para produção, reduzindo assim a produtividade brasileira. Dessa forma, o crescimento pode ficar comprometido.

De acordo com Stiglitz e Walsh (2003) e Mankiw (2005), um dos meios de promover o crescimento de longo prazo é pelo aumento da poupança e conseqüente aumento do investimento em capital.

Os investimentos e a forma como são realizados estão, portanto, na raiz do processo de desenvolvimento econômico e social. A poupança, que viabiliza os investimentos, é outro componente essencial do processo. E a eficiência na utilização da poupança é crucial, pois ela determina o custo do investimento. A melhor conjugação de todos esses fatores gera o círculo virtuoso do desenvolvimento, que permite à sociedade desfrutar de níveis crescentes de bem-estar e de redução da pobreza. (BOVESPA, 2000, p.6) 
O crescimento econômico esta associado a elementos incentivadores da formação de poupança e de sua intermediação eficiente, que a torne possível para quem quer investir. Bovespa (2000) considera três maneiras de se associar poupança à investimento: (1) autofinanciamento das empresas, (2) o financiamento do governo através de tributos ou mecanismos compulsórios e (3) financiamento via mercado de capitais. Através do mercado de capitais é possível associar poupança e investimento de maneira eficiente. De acordo com Bovespa (2000), a função primordial dos mercados financeiros é aproximar os dois agentes de mercado: o poupador (que tem excessos de recursos, mas não tem oportunidade de investir em atividades produtivas) e o tomador (que não tem recursos disponíveis para investir em atividades produtivas).

Uma outra maneira de aumentar o investimento em capital e gerar crescimento é através do investimento estrangeiro direto (IED). Mesmo que parte dos benefícios desse investimento retorne ao proprietário estrangeiro (através de lucros), o investimento aumenta o estoque de capital da economia levando a maior produtividade, maiores salários, mais empregos e promovendo a troca de tecnologias.

Alguns países menos desenvolvidos tentaram atingir um crescimento econômico adotando medidas protecionistas. Essas políticas têm por objetivo aumentar a produtividade e os padrões de vida dentro do país, evitando interação com o resto do mundo por meio de tarifas e restrições ao comércio. Atualmente acredita-se que os países pobres se dão melhor quando adotam políticas que os integrem à economia mundial. A integração entre os países permite a troca de tecnologias, o que favorece o aumento de produtividade. 


\subsubsection{DESENVOLVIMENTO ECONÔMICO}

Sachs (2001), assim como outros autores, defende que o crescimento econômico é uma condição necessária para o desenvolvimento. Dessa forma, crê-se que através do crescimento econômico pode-se melhorar as condições de vida da população. Há um consenso entre os economistas de que o crescimento econômico é avaliado pelo aumento do PIB. Contudo, com relação ao desenvolvimento econômico não existe o mesmo consenso.

Em termos econômicos, pode-se dizer que quanto maior for o PIB, maiores são as chances de a população viver bem. No entanto, um fator importante que deve ser considerado é o tamanho da população. Assim, uma primeira aproximação para se quantificar o grau de desenvolvimento de um país é a utilização do conceito de produto per capita. Dessa forma, quanto maior for o PIB per capita de um país, mais desenvolvido será o país (GREMAUD; VASCONCELLOS; TONETO JR., 2002).

Deve-se notar, porém, que o conceito de PIB per capita é uma média, representando a renda média da população de um país, portanto deve-se considerar a dispersão em relação à média. Dessa forma, infere-se que a renda de alguns indivíduos está acima, e de outros está abaixo da média. Ou seja, mesmo que um país tenha um PIB per capita elevado, caso a distribuição de renda seja concentrada, o país pode não ser considerado desenvolvido.

Schumpeter (1996), ao separar crescimento de desenvolvimento econômico, atenta para a discussão conceitual sobre o assunto. De acordo com Souza (2005, p. 148):

[...] o desenvolvimento schumpteriano traduz-se por mudanças quantitativas e qualitativas das variáveis econômicas de fluxo circular, alterando sua estrutura e as condições do equilíbrio original. Aumenta a disponibilidade de bens per capita, em razão da maior taxa de crescimento da produção em relação à população. Melhora a qualidade dos produtos e dos serviços, assim 
como a renda média dos indivíduos. Isso ocorre pela expansão do volume de negócios, pelas inovações e pela disputa por fatores de produção por parte dos empresários. O dinamismo da economia deriva da ação do empresário inovador, que põe em prática novos processos de produção, gera novos produtos e abre novos mercados [...].

Alguns autores colaboram com essa discussão conceitual sobre o tema. Veiga (2005) sugere que o conceito de desenvolvimento pode ser entendido como sinônimo de crescimento econômico. Entretanto, para Gremaud, Vasconcellos e Toneto Jr. (2002), o crescimento econômico é a ampliação quantitativa da produção, ou seja, de bens que atendam as necessidades humanas e desenvolvimento econômico, que além do conceito de crescimento, engloba outros conceitos mais amplos, como a natureza do crescimento do PIB e as condições de vida da população do país.

Ainda que não exista definição universalmente aceita para desenvolvimento (SOUZA, 2005), alguns autores buscam conceituá-lo. Para Kindleberger e Herrick (1977), o desenvolvimento econômico é "um aumento na produção acompanhado de modificações nas disposições técnicas institucionais, isto é, mudanças nas estruturas produtivas e na alocação de insumos pelos diferentes setores de produção”. Colman e Nixson (1981) conceituam desenvolvimento econômico como "um processo de aperfeiçoamento da relação a um conjunto de valores desejáveis pela sociedade". Para Seers (1972), desenvolvimento é a "criação de condições para a realização da personalidade humana", considerando aspectos relacionados à pobreza, desemprego e desigualdades.

Dessa forma, pode-se sintetizar crescimento econômico como o aumento contínuo do produto nacional em termos globais ou per capita ao longo do tempo, implicando melhor eficiência do sistema produtivo e desenvolvimento econômico como mudanças de caráter quantitativo dos 
níveis do produto nacional, que alteram a composição do produto e alocação dos recursos pelos diferentes setores da economia (GREMAUD et al, 2003).

Gremaud et al (2003) considera que, para caracterizar um processo de desenvolvimento econômico, devem ser observados ao longo do tempo a existência de crescimento do bemestar econômico, diminuição do nível de pobreza e melhoria das condições de saúde. Assim, para que se tenha desenvolvimento econômico é necessário que haja crescimento econômico. Souza (2005) considera ainda que o crescimento da renda per capita é fundamental para melhorar indicadores sociais.

Segundo Salama (2001), testes econométricos atribuem importante papel à distribuição de renda para explicar o crescimento, afirmando que quanto menos importantes as desigualdades de renda, medidas pela relação entre os dois (ou quatro) primeiros decis e dois últimos, mais vivo e durável é o crescimento, e inversamente. Para medir a desigualdade, dois importantes indicadores usados são o índice de Gini e o índice de Theil (SOUZA, 2005; HOFFMANN, 1998b).

Souza (2005) considera que o índice de Gini mede a distribuição de renda entre as classes sociais. Segundo Hoffmann (1998b), o índice de Gini, assim como a variância dos logaritmos e o índice de Theil, é uma das medidas de concentração ou desigualdade e pode ser utilizada para medir o grau de desigualdade de qualquer distribuição estatística. Freqüentemente esse índice é utilizado para mensurar o grau de desigualdade da renda em uma população.

Hoffmann (1998a) ainda considera outros indicadores. De acordo com o autor, outros índices são utilizados para medir o grau da pobreza, como a proporção de pobres, a insuficiência de 
renda, o índice de pobreza de Sen e o índice de Foster, Greer e Thorbecke (HOFFMANN, 1998a e HOFFMANN, 1998b).

Souza (2005), entretanto, afirma que os indicadores de desenvolvimento podem ser substituídos pelo Índice de Desenvolvimento Humano (IDH) elaborado pelo Programa das Nações Unidas para o Desenvolvimento (PNUD). De acordo com o Atlas do Desenvolvimento Humano no Brasil (PNUD, 2003), o IDH foi criado originalmente para medir o nível de desenvolvimento humano dos países a partir de indicadores de educação, longevidade e renda. O índice varia de 0 (nenhum desenvolvimento humano) a 1 (desenvolvimento humano total). Vale considerar que a metodologia adotada para o cálculo do IDH mudou algumas vezes para o cálculo dos três indicadores. Assim, a despeito da indicação de Souza (2005), esse indicador pode apresentar inconsistência de dados na série histórica devido à mudança de metodologia, e precisa ser analisado com cautela.

[...] Todos os anos, desde 1990, este relatório tem publicado um índice de desenvolvimento humano (IDH) que olha para além do PIB para uma definição mais ampla de bem-estar. O IDH apresenta uma medida conjunta de três dimensões do desenvolvimento humano: viver uma vida longa e saudável (medida pela esperança de vida), ter estudos (medido pela alfabetização de adultos e pelas matrículas nos níveis primário, secundário e superior) e ter um padrão de vida decente (medido pelo rendimento de paridade do poder de compra, PPC). O índice não é, de forma alguma, uma medida abrangente do desenvolvimento humano. Por exemplo, não inclui indicadores importantes como o respeito pelos direitos humanos, a democracia e a desigualdade. O que fornece é um prisma mais amplo para encarar o progresso humano e a relação complexa entre rendimento e bemestar. (PNUD, 2006, p. 263)

Segundo Veiga (2005, p. 90), “quando aplicada a municípios, a média aritmética no IDH embaralha dois fatos essenciais: a freqüência de municípios abastados que arrastam precárias condições sociais e a existência de municípios com condições sociais dignas apesar de serem relativamente pobres". 


\section{FLUXOS INTERNACIONAIS DE BENS E CAPITAIS}

A liberação comercial ocorrida após 1990 promoveu mudanças que favoreceram a entrada de investimentos estrangeiros para o Brasil, direcionada, em parte, para as privatizações, aumentando a competitividade de algumas dessas empresas. Como conseqüência desse aumento de competitividade, da estabilização promovida pelo Plano Real e pelas mudanças cambiais ocorridas nesse período, o cenário brasileiro mudou, propiciando um aumento de exportações. Dessa forma, o período conhecido como globalização, acentuado na década de 90, foi caracterizado por um intenso fluxo internacional de bens e capitais.

Mankiw (2005) classifica fluxos internacionais de bens e capitais separadamente. Para o autor, os fluxos de bens são as exportações, importações e o saldo da balança comercial (ou exportações líquidas). Já os fluxos de capitais referem-se ao fluxo líquido de capitais externos (investimento externo líquido). Assim, para uma melhor compreensão desse assunto, esta seção aborda os tópicos: Globalização, Investimentos Estrangeiros Diretos e Comércio Internacional.

\subsection{GLOBALIZAÇÃo}

A questão da globalização tem estado cada vez mais presente nos debates sobre as transformações nacionais e mundiais (BAUMANN; CANUTO; GONÇALVES, 2004), porém o termo "globalização" não é consensual. Esse termo foi cunhado nas escolas de business administration nos Estados Unidos na década de 80, ganhando espaço na mídia mundial, e sua vulgarização gerou, ao mesmo tempo, conceitos e publicações equivocadas, além de rejeição do tema por alguns pesquisadores acadêmicos (LASTRES, 1997). Para Batista Jr. 
(1998), o próprio vocábulo - "globalização", “mundialização”, “neoliberalismo”, empresas "transnacionais" e "multinacionais" - está contaminado de distorções e conotações ideológicas.

Os tipos específicos de globalização que estão relacionadas ao investimento internacional são a globalização financeira, que trata dos fluxos financeiros e a globalização produtiva, que se refere aos fluxos de investimento estrangeiro direto e a atuação das empresas transnacionais (BAUMANN; CANUTO; GONÇALVES, 2004). Para os autores, a globalização financeira pode ser entendida como a interação de três processos distintos ao longo dos últimos vinte anos: (1) a expansão extraordinária dos fluxos financeiros internacionais (inclusive na forma de empréstimos, financiamentos e investimentos em portfólio), (2) o acirramento da concorrência nos mercados internacionais de capitais (em decorrência da disputa por transações financeiras internacionais envolvendo bancos e instituições financeiras não bancárias), e (3) a maior integração entre os sistemas financeiros. Já a globalização produtiva, segundo os autores, envolve (1) o processo de internacionalização da produção, (2) o acirramento da concorrência internacional, e (3) a maior integração entre as estruturas produtivas das economias nacionais.

A despeito de muitos analistas não acreditarem nesse processo, todos reconhecem que na esfera das transações financeiras internacionais atingiu-se algo inédito e de abrangência global (DALCERO, 1997). Esse rápido crescimento das transações financeiras internacionais é explicado pela telemática (progresso tecnológico na área de telecomunicações e informática), diminuindo os custos de transações e eliminando as fronteiras nacionais, pela desregulamentação do mercado financeiro internacional e pelas inovações financeiras que 
possibilitaram o aparecimento de novos produtos financeiros, permitindo ao mercado opções de hedge e especulação (GREMAUD et al, 2003).

Baumann, Canuto e Gonçalves (2004) enumeram outros fatores determinantes para a globalização financeira: (1) os fatores de ordem ideológica e a ascensão das idéias liberais ao longo dos anos 80 , que promoveram a desregulamentação do sistema financeiro em escala global; (2) as inovações e o processo de adaptação institucional do sistema financeiro internacional gerado a partir da instabilidade com a quebra do sistema Bretton Woods; (3) o progresso tecnológico da informática e das telecomunicações; (4) as mudanças estratégicas dos investidores institucionais e das empresas transnacionais; (5) as políticas econômicas adotadas pelos países desenvolvidos nas últimas décadas; e (6) fatores de ordem sistêmica, em que a globalização financeira é vista como parte integrante de um movimento de acumulação em escala global.

Autores como Chesnais (1996, 1998), Fiori (1995) e Coutinho (1996) refletiram sobre a necessidade de esclarecer o verdadeiro significado teórico do termo globalização. Sene (2004, p.37) afirma que globalização "nada mais é do que um processo histórico, que aliás, vem de longa data". Para a maioria dos outros autores, a globalização é vista como um processo recente, devido às transformações intensas do capitalismo internacional na década de 80, que alteraram as bases tecnológicas, produtivas, comerciais e financeiras (GOLDSTEIN, 1995). Apesar disso, o processo de globalização, sob o ponto de vista histórico, é bem mais antigo. Esse conceito é freqüentemente relacionado à expansão da civilização européia no século XV, no processo de internacionalização e criação de um mercado de alcance mundial através da colonização, que resultou na ampliação das desigualdades entre os países colonizadores e os demais países (BATISTA JR., 1998 e GENRO, 2000). O processo de globalização, iniciado 
no século XV pelas viagens marítimas, passou por várias fases: a fase do imperialismo no século XIX, com a conquista de novos mercados na Ásia e na África; o período de incentivo ao comércio no período de guerras e no pós-guerra, com a criação do Acordo Geral sobre Tarifas e Comércio (GATT), que buscava a redução das barreiras e fomento do comércio mundial.

Conceitualmente, globalização pode ser resumida como a significativa expansão do comércio internacional e fluxos de capitais, concomitantemente ao avanço tecnológico e da telemática (LACERDA, 2004b). "No nível mundial, a globalização representa a crescente interdependência entre os países, que se reflete nos fluxos de bens, serviços, capital e know how que atravessam fronteiras" (BRUNI, 2002, p.3). A fase atual da globalização configurase como uma etapa posterior à internacionalização da economia, em que ocorre a integração da produção de bens, serviços, fluxos de capital e comércio, gerando interdependência entre as organizações e as nações (MILLER, 1995 e SAVÓIA, 1996).

A integração das economias e a redução de barreiras comerciais transformam o mundo em um mercado global, o que favorece grandes empresas e conglomerados que dispõem de recursos e fatores de produção para obter economia de escala e vantagem competitiva (MAIA, 2004). As desigualdades entre as nações, ocasionadas pela colonização ou pelo domínio comercial, também são discutidas sob o prisma do processo de globalização. Os processos de globalização e de regionalização (formação de blocos econômicos) significam um desafio para os países em desenvolvimento, uma vez que conjugados também podem significar a "exclusão involuntária” (LACERDA, 2004b). Os benefícios e os prejuízos do comércio, ou do livre comércio ainda são temas de discussão no atual processo de integração das economias. 
Para Prebisch (1963), o livre comércio não promoveria desenvolvimento para os países da periferia, portanto, estes deveriam se desenvolver por meio da industrialização. A implantação de uma estrutura industrial e a consolidação dessa estrutura de bens de capital marcaria o salto para um novo patamar de desenvolvimento (FELTRIN, 2005). Essas reflexões confrontavam as idéias de David Ricardo, que defendia o livre comércio como forma de prover ganhos aos países por intermédio da Teoria das Vantagens Comparativas (RICARDO, 1996). Segundo $\operatorname{HOLANDA}^{5}(1996)$ :

[...] as trocas internacionais seriam vantajosas mesmo em uma situação em que um determinado país tivesse maior produtividade que o outro na produção de todas as mercadorias. [...] A teoria das vantagens comparativas ainda tinha muita força entre os economistas da maioria dos países na entrada dos anos 50, quando se iniciava a etapa da rápida industrialização nos países subdesenvolvidos. [...] Para demonstrar o desacerto das proposições retiradas do esquema ricardiano de vantagens comparativas, os economistas latino-americanos diziam que o universo ricardiano não podia funcionar perfeitamente nas condições que se apresentavam nas trocas entre os países centrais e a periferia, porque os pressupostos do livre-cambismo não ocorriam de maneira perfeita - nem os ganhos de produtividade ocorridos nos países centrais eram repassados aos preços dos produtos (a organização dos trabalhadores e o monopólio das novas tecnologias faziam reter estes lucros sob a forma de salários maiores, lucros extraordinários ou de repasses ao Estado de Bem-Estar), nem na periferia os ganhos de produtividade podiam ser retidos em função da desorganização do mercado de trabalho, pela heterogeneidade entre os setores econômicos, etc. [...] (HOLANDA, 1996, p.11 in RICARDO, 1996)

A discussão sobre os benefícios ou prejuízos do livre comércio e da divisão internacional da produção foram temas abordados por diversos autores. Para Maia (2004), a liberalização da economia permitiria que os consumidores tivessem acesso aos produtos mais baratos, já que não haveria barreiras protecionistas encarecendo os produtos. Gershenkron ${ }^{6}$ (1962 apud ALMEIDA, 2004, p. 20) considera que países menos desenvolvidos poderiam dar saltos tecnológicos adotando técnicas e processos produtivos disponíveis nos países mais

\footnotetext{
${ }^{5}$ HOLANDA, Felipe Macedo - O autor fez a apresentação da reedição da obra de Ricardo (1996)

${ }^{6}$ GERSHENKRON, Alexander Economic backwardness in historical perspective, Cambridge, Massachusets: Harvard University Press, 1962
} 
desenvolvidos, e assim buscar o desenvolvimento. Dessa forma, a situação centro-periferia poderia ser alterada dependendo da capacitação endógena ou adquirida. Esses, dentre outros benefícios, poderiam teoricamente ser aplicados aos países em desenvolvimento. No entanto, existe muita diferença entre o discurso e a prática dos países desenvolvidos, que têm discurso liberalizante e postura protecionista (LACERDA, 2004b).

A complexidade das relações entre globalização e desenvolvimento dificulta a avaliação precisa dos efeitos do processo de integração das economias para o aumento do bem-estar para as populações. Para alguns pesquisadores, a globalização pode provocar crises internacionais e, a partir disso, desemprego e miséria. Entretanto, outros estudos, considerando outras metodologias e perspectivas estatísticas, evidenciam que as taxas de pobreza e desigualdades globais na repartição de renda têm declinado na última década (ALMEIDA, 2004).

A exemplo da discussão sobre a influência da globalização na diminuição do desenvolvimento e da pobreza, estudos de Sala-i-Martin (2002) e Bhalla (2002) indicaram que a globalização resultou em uma diminuição sensível das desigualdades mundiais e da pobreza, promovendo um crescimento relativo de renda das classes mais pobres. Segundo os pesquisadores, existe uma tendência ascendente de desenvolvimento na Ásia e desenvolvimentos menores, ou até mesmo estagnação, em países da América Latina e África.

Majid (2003), em um estudo realizado para a Organização Mundial do Trabalho, observou efeitos similares a Sala-i-Martin (2002) e Bhalla (2002), constatando que a abertura comercial contribuiu para o desenvolvimento do crescimento e que não há evidências de que o aumento do comércio exterior aumente as desigualdades sociais internamente. 
Com as mudanças promovidas pela globalização financeira e as divergências sobre os efeitos dessas mudanças nas economias, busca-se analisar as conseqüências para o caso brasileiro e efeitos. O regime atual de globalização financeira é movido basicamente por três fatores: o volume crescente de riqueza monetária e financeira, a mobilidade desses ativos propiciada pelo desenvolvimento da telemática, e o regime de taxas de câmbio que propicia oportunidades de ganhos especulativos (CORAZZA, 2004).

O Brasil consegue se inserir na nova onda de globalização financeira em meados de 1990, que a partir da estabilização do Plano Real, das reformas internas e das privatizações, atraiu grande volume de investimentos estrangeiros diretos. Esse processo extrapolou as fronteiras nacionais configurando-se em um fenômeno internacional, magnificado pela liberalização dos mercados cambiais e pela desregulamentação dos os fluxos de capitais (LACERDA, 2004b e RAMBO, 2001).

O Plano Real foi, então, um dos produtos dos mercados financeiros globalizados, desregulamentados e líquidos. O país oferecia altas taxas de juros e a possibilidade de se adquirir ativos subvalorizados, sobretudo com a perspectiva de ampliação do programa de privatização. [...] Um traço do funcionamento fundamental desses mercados é a natureza volátil dos fluxos de capitais. [...] A volatilidade inerente aos fluxos de capitais afeta, sobretudo os países "emergentes" devido às assimetrias do sistema monetário e financeiro internacional. A primeira dimensão dessa assimetria diz respeito aos determinantes dos fluxos de capitais direcionados aos países "emergentes". Esses fluxos são determinados, sobretudo, por um dinâmica exógena a esses países, especificamente, o ciclo econômico e a política monetária dos países centrais e as decisões de aplicação e resgate dos investidores globais, subordinados à lógica especulativa. A segunda dimensão da assimetria financeira refere-se à dimensão relativa dos fluxos de capitais destinados à periferia (CINTRA; PRATES, 2004, p. 2).

A estratégia do Plano Real constituiu-se basicamente na fixação da taxa de câmbio, como âncora nominal dos preços, na abertura financeira para facilitar o ingresso de capitais e na elevação da taxa doméstica de juros como atrativo de capitais, contenção de demanda e preços 
internos (CORAZZA, 2004). A fixação do câmbio e a valorização imediata da moeda nacional tiveram como resultados a inversão da tendência da Balança Comercial e o déficit na Conta Corrente do Balanço de Pagamentos, que tornou o Brasil dependente de recursos externos.

A nova fase de acumulação capitalista tem na globalização elementos de transformação e reestruturação das economias. A revolução tecnológica, o processo de concentração de grandes conglomerados indústrias e de serviços tem impulsionado mudanças, projetando para o futuro a possibilidade de uma sociedade planetária unificada (GORENDER, 1995). Contudo, a tentativa de unificação entre os países desenvolvidos e em desenvolvimento, promovida pela globalização, não ocorre de forma igualitária. Segundo Gorender (1995, p. 103):

[...] Os países atrasados ditos em desenvolvimento e também designados como países do Terceiro Mundo, têm as economias mais suscetíveis de debilitamento diante dos impulsos imprimidos à globalização pelas empresas multinacionais e pelo capital financeiro atuante no âmbito mundial. A fraca autonomia de decisões dos seus Estados nacionais é ainda mais reduzida, ou mesmo anulada pelos fatores externos que procedem dos centros comandantes da economia mundial. [...]

Para corroborar essa idéia, Luquini (2003) afirma que os mercados financeiros adquiriram uma crescente autonomia em relação aos Estados, pois o capital se move de um país a outro em busca do retorno máximo, comprometendo a capacidade dos governos em controlar suas economias. Assim, a atuação dos Estados fica restrita pelas novas relações econômicas, pois a riqueza e o poder são cada vez mais frutos das transações privadas que ocorrem fora das fronteiras dos países.

A despeito da visão de Gorender (1995) e Luquini (2003), Batista Jr. (1998) acredita que o enfraquecimento do Estado é um mito alimentado pelos neo-liberais que alertam para os 
riscos econômicos e políticos da intervenção do governo. Segundo Batista Jr. (1998), com a globalização, o Estado entrou em declínio ou desmantelamento em muitas regiões, especialmente África e América Latina, porém sua participação não diminuiu nos países mais adiantados.

\begin{abstract}
Mesmo no setor financeiro, área em que mais avançou o processo de internacionalização, o papel do Estado continua crucial. O funcionamento dos mercados financeiros domésticos e internacionais continua dependendo decisivamente da atuação dos Estados nacionais no campo regulatório ou como emprestadores de última instância em momentos de crise financeira (BATISTA JR., 1998, p. 162).
\end{abstract}

No Brasil, a inserção no sistema global tem como consequiências a redução da forma normativa e indutora do Estado e a afirmação de um modelo baseado no neo-rentismo (GENRO, 2000 e GORENDER, 1995). Tais efeitos tendem a criar uma sociedade fragmentada em espaços sociais: os incluídos, os semi-incluídos e os marginalizados ou excluídos (GENRO, 2000). Portanto, globalização e exclusão são dois conceitos que definem realidades interligadas. $\mathrm{O}$ primeiro designa as características atuais do processo de desenvolvimento do capitalismo em nível mundial, e o segundo, sua conseqüência mais visível e imediata (SANTOS, 2001). Para Chesnais (1996), a economia global é excludente. Um aspecto que deve ser levado em conta é que em grande parte dos países industrializados, está ocorrendo um distanciamento entre os setores produtivos ligados ao capital internacionalizado dos setores retardatários, causando desemprego e exclusão social (SANTOS, 2001).

Furtado (1992) afirma que a estrutura internacional de poder evoluiu para assumir a forma de grandes blocos de nações-sede de empresas transnacionais que dispõem de conhecimento e de pessoal capacitado. O prosseguimento do avanço das empresas transnacionais, graças à crescente concentração de poder financeiro e acordos sobre patentes e atividade intelectual, contribui para aumentar o fosso existente entre países desenvolvidos e subdesenvolvidos. 
Para Lacerda (2004b), as empresas transnacionais representam o grande fator indutor dos investimentos estrangeiros diretos e do comércio internacional.

As mudanças ocorridas na década de 90 promoveram abertura de capital e, conseqüentemente, entrada de investimento estrangeiro nas privatizações, modificando a estrutura acionária das empresas brasileiras. Utilizando definição da Conferência das Nações Unidas sobre o Comércio e Desenvolvimento (UNCTAD), Lacerda (2004b) esclarece que uma participação acionária igual ou superior $10 \%$ das ações comuns do poder de voto de uma empresa geralmente é considerada transnacional.

Contrariamente às interpretações convencionais, os agentes mais dinâmicos da globalização não são os governos nem os representantes parlamentares dos países que formaram mercados comuns à procura de integração econômica. As forças mais ativas e poderosas no processo de globalização são os conglomerados e empresas transnacionais que dominam e controlam efetivamente a maior parte da produção, do comércio, da tecnologia e das finanças internacionais. Com seu imenso potencial econômico-financeiro, essas organizações operam em escalas transcontinentais, transferindo recursos financeiros e know-how por sistemas de comunicações informatizadas e via satélite e crescem, mesmo em tempos de recessão e crise, através de fusões, incorporações, venda e compra de ativos em transações bilionárias. (RATTNER, 1995, p. 71)

Assim, para melhor compreensão do papel das empresas transacionais e do investimento estrangeiro direto em empresas brasileiras, o próximo tópico aborda a questão do papel do investimento estrangeiro direto no aumento da competitividade, na geração de desenvolvimento e na aquisição de empresas brasileiras. 


\subsection{INVESTIMENTOS ESTRANGEIROS DIRETOS}

Para promover crescimento e desenvolvimento, além financiar o investimento interno, os países em desenvolvimento recorrem intensamente a fluxos de entrada de capitais do exterior, sendo que uma das maneiras mais utilizadas é o investimento estrangeiro direto.

Investimentos Estrangeiros Diretos são os fluxos internacionais de capitais pelos quais uma firma de determinado país cria ou expande uma filial sua em outro, não se configurando, neste caso, apenas uma transferência de recursos, mas também a aquisição do controle (KRUGMAN; OBSTFELD, 2005, p. 126). O investimento interno pode ser analisado pela equação identidade do PNB. A equação é descrita pela equação:

$\mathrm{TC}=\mathrm{S}-\mathrm{I}$

em que TC é o saldo em transação corrente; $\mathbf{S}$ é a poupança nacional e $\mathbf{I}$ é o investimento doméstico.

Por causa da pobreza dos países em desenvolvimento e da fragilidade de suas instituições, a poupança nacional é normalmente baixa, e como esses países são relativamente pobres em capital, as oportunidades de introduzir indústrias e equipamentos de maneira lucrativa são abundantes, justificando o investimento doméstico (KRUGMAN; OBSTFELD, 2005). Ao apresentar um déficit em suas transações correntes, um país pode obter recursos do exterior para investir, mesmo que seu nível de poupança doméstica seja baixo. 
Quando um país apresenta déficit em transações correntes é sinal de que ele está vendendo ativos aos estrangeiros para financiar a diferença entre seus gastos e sua renda. Para Porcile e Curado (2002, p.484) “a persistência de desequilíbrios na balança comercial é uma característica marcante da trajetória de crescimento dos países em desenvolvimento e, em especial, dos países da América Latina”. Os fluxos de entrada de capital que financiam déficits em países em desenvolvimento podem assumir diversas formas. Os financiamentos podem ser por dívida ou por controle acionário (KRUGMAN; OBSTFELD, 2005).

Os financiamentos por dívida podem ser feitos por meio de financiamento por títulos, como ocorrido no período entre guerras - 1918-1939; financiamento por bancos, realizado no início dos anos 70 e final dos anos 80; e de empréstimos oficiais, como no pós-guerra por intermédio dos bancos de fomento BIRD e BID. Os financiamentos por controle acionário são o investimento estrangeiro direto, pela aquisição ou expansão de filial ou fábrica localizada no país, e os investimentos em carteira no controle acionário de firmas, por meio das privatizações ocorridas na década de 90 (KRUGMAN; OBSTFELD, 2005, p. 501).

Os investimentos estrangeiros vêm crescendo nos últimos 45 anos. Entretanto, essa expansão tem sido mais acelerada desde meados dos anos 80 , quando os fluxos de IED passaram a ter uma taxa de crescimento maior do que os fluxos de comércio e do que o crescimento do PIB mundial (HIRATUKA, 2000). O cenário nos anos 80 foi marcado pela crise da dívida dos países em desenvolvimento. A partir da crise de 1982, o mercado passou a financiar mais empresas transnacionais do que países em desenvolvimento (DALCERO, 1997). Os projetos de investimento direto são sujeitos aos riscos econômicos, financeiros, de inflação e câmbio, e também ao risco político (GITMAN, 2004). Assim, a crise da década 80, conhecida como 
década perdida, fez com que os fluxos de capitais estrangeiros direcionados aos países permaneceram estagnados (LAPLANE E SARTI, 1999).

“Ao longo das décadas de oitenta e noventa houve uma extraordinária expansão dos fluxos estrangeiros, assim como das exportações em nível mundial, no bojo do processo da globalização" (LACERDA, 2004a, p. 619). Os investidores estrangeiros buscavam oportunidades em praças de maior risco, principalmente após a redução da taxa de juros básica dos Estados Unidos no início da década de 90 (CINTRA; PRATES, 2004). Nesse contexto, uma série de outros fatores fizeram com que houvesse um grande fluxo de capitais para o Brasil: a abertura comercial, a redução das restrições de atuação setorial, a renegociação da dívida externa, as privatizações, as fusões e aquisições e o Mercosul. Segundo (LACERDA, 2004a, p. 622):

[...] o Brasil, que estivera ausente do mapa de investimentos externos ao longo da "década perdida" nos anos oitenta, reingressara na rota destes investimentos nos noventa, especialmente depois da implantação do Real (1994). A queda da inflação, que era a última resistência dos investidores ao mercado brasileiro, veio consolidar o cenário receptivo às novas inversões, definido anteriormente pela abertura comercial, a redução das restrições de atuação setorial e a renegociação da dívida externa. Mais tarde, as privatizações e o boom das fusões e aquisições também foram fatores determinantes, assim como a emergência do Mercosul.

Excetuando-se as economias industrializadas (Estados Unidos, Reino Unido, França, Bélgica e Luxemburgo), o Brasil e a Argentina, ao lado da China, estão entre os principais receptores em termos de investimento estrangeiro direto (LAPLANE E SARTI, 1999).

O ingresso de investimentos diretos provoca uma reestruturação produtiva nas economias, alterando, entre outros aspectos, o seu padrão de comércio. Três fatores foram estimulantes para a reconstrução e capacitação produtiva: a busca de maior inserção internacional no início 
dos anos 90, a maior concorrência com importados e a entrada de novas empresas estrangeiras (LAPLANE E SARTI, 1999).

Parte da reestruturação da economia brasileira decorreu do processo de venda de empresas públicas a partir de 1990, com o Programa Nacional de Desestatitização (PND), gerando caixa para o governo e promovendo modificação patrimonial no controle acionário do mercado brasileiro (CORDEIRO, 2005). A participação estrangeira na privatização brasileira foi expressiva. O Brasil passou a ser pólo de atração dos investimentos estrangeiros utilizados no processo de privatização na década de noventa (LAPLANE E SARTI, 1999). A partir de 2000 houve redução dos investimentos diretos para o Brasil em conseqüência da deterioração das condições econômicas no Brasil e no mundo, e do encerramento do processo de privatizações de empresas públicas (LAPLANE; GONÇALVES; ARAÚJO, 2004).

$\mathrm{Na}$ primeira fase, o processo de privatização constituiu-se em transferência de controle acionário, porém, o que se esperava da fase seguinte era o investimento na ampliação de serviços e modernização, fator decisivo na redução de custos e melhoria da qualidade. Com as privatizações e a movimentação de capital, as empresas estrangeiras passaram a deter fatia considerável das exportações e importações do país, com reflexos diretos na dinâmica do comércio exterior, influenciados pelas estratégias das empresas transnacionais e, em especial, do comércio intra-firma (LACERDA, 2004a).

Como ilustração, no período entre 1995 e 2000, enquanto as exportações totais do Brasil cresceram 18,4\%, as exportações das empresas com participação estrangeira aumentaram 53\%. Enquanto, em 1995, as empresas estrangeiras detinham 46,8\% das exportações totais, em 2000 as empresas estrangeiras detinham o equivalente de 60,4\% das exportações totais 
brasileiras (LACERDA, 2004a). O desempenho de comércio exterior das filiais das empresas nacionais também é devido às estratégias de localização da produção que impulsiona o comércio de partes, componentes, produtos e serviços.

Segundo Laplane e Sarti (1999), a análise dos impactos do ciclo de investimentos no fim da década de noventa focaliza quatro perspectivas relevantes para o crescimento sustentado: a desnacionalizacão da estrutura produtiva, o aumento das remessas de lucro, a competitividade na indústria e a balança comercial.

O predomínio de investimentos estrangeiros no processo de fusões, aquisições e privatização têm provocado a desnacionalização da estrutura produtiva.

A reinserção da economia brasileira nos fluxos internacionais de investimentos destinados aos países em desenvolvimento a partir dos anos 1990 implicou um crescimento do grau de desnacionalização da maioria dos setores, fazendo com que as empresas estrangeiras aumentassem sua participação no faturamento em detrimento das empresas estatais. (LACERDA, 2004a).

Com a desnacionalização, fusões, aquisições e privatizações, grandes empresas passaram a ter controle estrangeiro, e grande parte dos lucros e capital produzido no país passou a ser reenviada para seus países de origem. As crises financeiras e o receio de que o Brasil fosse obrigado a realizar desvalorização cambial, para evitar a fuga em massa de capitais e para ajustar o desequilíbrio em sua balança comercial, podem ter contribuído para a antecipação das remessas de lucro para o exterior (LAPLANE E SARTI, 1999). O envio de remessas para o exterior não gera o desenvolvimento no país, uma vez que não proporciona modernização e desenvolvimento para as indústrias e, conseqüentemente, para o país.

É importante observar que os investimentos estrangeiros podem não significar desenvolvimento interno, pois o fluxo de recursos obtidos com a privatização tende a se 
esgotar no fim do processo, sem promover a ampliação da nova capacidade, o montante de investimentos em modernização e infra-estrutura devem ser inferiores aos envolvidos na aquisição. A crescente participação de capital estrangeiro pode induzir a uma maior remessa de lucros para o exterior (LAPLANE; SARTI, 1999).

Segundo Prebisch $(1963,1986)$, a persistência dos desequilíbrios na balança comercial pode ser explicada, entre outros fatores, pela lenta e desigual difusão do progresso técnico em escala internacional, da qual emergem assimetrias tecnológicas entre países que se traduzem em diferenças de competitividade internacional. Assim, a entrada de investimento na ampliação de serviços e modernização, é fator decisivo na redução de custos e melhoria da qualidade.

No início da década de 90, a busca pela competitividade e modernização das indústrias brasileiras foi feita em péssimas condições: obsolescência de parte do sistema industrial, após a década perdida, quase ausência de política industrial, forte valorização da moeda nacional e liberalização rápida do comércio exterior (SALAMA, 2001).

Com a modernização, as empresas tendem a melhorar a qualidade e reduzir os custos dos produtos e serviços, aumentando assim sua competitividade. Dessa forma, as empresas podem optar por duas estratégias: manter o mesmo nível de preços e incrementar seus ganhos na margem de lucro, aumentando sua rentabilidade, ou reduzir os preços de seus produtos e serviços para ganhar novos mercados no exterior (MATARAZZO, 1998; GITMAN, 2004), o que pode refletir em uma melhora no saldo da balança comercial. 
Segundo Rambo (2001), o crescente influxo de investimentos estrangeiros diretos para o Brasil é positivo, pois estes capitais, se investidos em setores que produzem produtos transacionáveis no comércio internacional (tradeables), criarão a médio e longo prazos uma capacidade produtiva no setor exportador.

De acordo com Blomström (1990), que estudou o efeito dos investimentos diretos sobre a competitividade das exportações para a América Latina, o investimento estrangeiro direto afeta positivamente o desempenho exportador das empresas locais. Analisando o caso brasileiro, Moreira (1999) afirma que, com a abertura da economia na década de 90, as empresas estrangeiras foram estimuladas a obter escalas mais competitivas e ganhos de especialização. O autor constatou que na década de 90 houve um crescimento de empresas estrangeiras e que, no período de 1995-1997, a propensão a exportar das empresas estrangeiras foi significativamente maior do que a das empresas brasileiras. O resultado dessa pesquisa foi similar ao encontrado por Wilmore (1982 e 1986) e Chudnovsky e Lopez (2002), que constataram um aumento da participação de empresas estrangeiras em manufaturados após a abertura da economia.

Analisando dados da UNCTAD, Hiratuka (2000) sugere que há interdependência entre o comércio internacional, a atuação das empresas transnacionais na geração de produtos e fluxos de comércio e dos investimentos diretos estrangeiros. O autor ainda destaca a importância das grandes transnacionais, que através de sua rede de filiais determinam e direcionam os fluxos de comércio, exercendo influência sobre os padrões de competitividade dos países onde operam as transnacionais. 
Apesar da diversa literatura sobre os impactos dos investimentos diretos estrangeiros no aumento de produtividade e crescimento, os resultados não são convergentes ou conclusivos. Segundo estudos feitos no México, Venezuela, República Tcheca, Índia, Brasil e alguns países da Europa, a relação entre produtividade e investimentos continua ambígua (BERTELLA; LIMA, 2005). Para Görg e Strobl (2000), que analisaram a relação entre empresas estrangeiras e aumento de produtividade, a diferença de estratégias de pesquisa, metodologia econométrica, seleção e tratamento dos dados podem influenciar os resultados obtidos.

Para Porter (1989), a prosperidade econômica depende da produtividade na qual os recursos nacionais são empregados. Dessa forma, o nível e o crescimento da produtividade são funções da variedade de indústrias e de segmentos de indústria, nos quais as empresas de um país podem competir com êxito, e da natureza das vantagens competitivas nela obtidas com o tempo. A vantagem competitiva pode ser impulsionada: (1) pelo investimento em tecnologia e estrutura; (2) pelos fatores de produção básicos, ou seja, recursos naturais, mão de obra e fatores favoráveis; e (3) pela inovação, ou seja, não apenas pelo aprimoramento de métodos e tecnologias, mas também pela criação de novos métodos e novas tecnologias.

Dada a relação entre investimento estrangeiro direto, empresas transnacionais, competitividade e comércio internacional, o tópico seguinte busca detalhar as teorias de comércio internacional, procurando evidenciar as ligações entre comércio internacional, crescimento e desenvolvimento econômico. 


\subsection{COMÉRCIO INTERNACIONAL}

Esta subseção aborda as teorias sobre comércio internacional e as considerações sobre o comércio brasileiro. Na primeira parte são analisados os modelos e teoremas relacionados ao crescimento e desenvolvimento econômico. Na segunda parte são discutidas as características do comércio brasileiro, analisando particularmente a evolução das exportações.

\subsubsection{TEORIAS SOBRE COMÉRCIO INTERNACIONAL}

Segundo Krugman (2005), o comércio internacional costuma ter forte influência sobre a distribuição de renda dentro dos países, gerando ganhadores e perdedores. Apesar de conhecer os efeitos do comércio internacional sobre a distribuição de renda, a maioria dos economistas acredita que é mais importante enfatizar os ganhos potenciais do comércio, ao invés das perdas que alguns grupos podem sofrer. Surgem, assim, teorias que buscam discutir os benefícios e as perdas do comércio entre as nações.

O comércio internacional existe desde a Antiguidade. A exemplo disso, pode-se considerar a unidade econômica promovida pelo império Romano, as feiras na região de Flandres e Champagne na idade Média, e o comércio do Mediterrâneo na época do renascimento, nas cidades de Gênova, Piza, Florença e Veneza (SOARES, 2004). Dada a necessidade dos países trocarem seus produtos, surgem as teorias clássicas de comércio que discutem a importância do comércio internacional. São elas o Mercantilismo, A Teoria das Vantagens Absolutas e a Teoria das Vantagens Comparativas. 
O Mercantilismo, conforme já foi mencionado, considerava que a riqueza de uma nação estava baseada no afluxo de metais preciosos e na balança comercial favorável. De acordo com Soares (2004), por essa teoria, o fator mais importante para a saúde de uma nação era a quantidade de metais preciosos que ela detinha e o comércio internacional era a melhor forma de obter metais e, portanto, riqueza e saúde econômica.

[...] Na concepção dos autores mercantilistas, quando uma nação ganha riqueza com o comércio internacional, outra nação perde. Depois vieram os pensadores clássicos e disseram que o comércio internacional traz vantagens para todos na medida em que possibilita o aumento do bem-estar social de ambos os parceiros comerciais. Muito mais tarde, vieram os teóricos modernos repletos de gráficos, equações e pesquisas para mostrar, como os clássicos já haviam feito, que o comércio traz vantagens para todos os países, mas alguns se beneficiam mais do que os outros porque são dotados de maior mercado doméstico, introduzem inovações e, enfim, detêm mais informação e capital. (SOARES, 2004, p. 63)

A Teoria das Vantagens Absolutas, de Adam Smith, considerava que cada país deveria se especializar na produção e na exportação de bens em cuja produção fosse mais eficiente, ou seja, que consumissem o menor número de horas de trabalho. Para Smith, "o fundamento do comércio internacional é justamente a divisão do trabalho, isto é, a especialização de cada país individual em determinados tipos de atividade econômica" (SOARES, 2004, p. 30). Contudo, as primeiras tentativas de explicar por que as nações comercializavam e quais produtos deveriam ser trocados foram feitas pelos economistas clássicos,com a Teoria das Vantagens Comparativas (GREMAUD et al, 2003).

Segundo o modelo das Vantagens Comparativas, de David Ricardo, o comércio internacional pode ser vantajoso para as nações participantes, uma vez que permite a utilização mais eficiente dos recursos econômicos, permitindo aos países em desenvolvimento importar bens de capital e intermediários a preços inferiores aos dos similares produzidos internamente (JAYME JR., 2001; RICARDO, 1996; NAPOLEONI, 1988). Dessa forma, cada país se 
especializa na produção, com baixo custos, de determinados bens e beneficia-se nas trocas internacionais onde vai vender o que produziu, gerando benefícios para a população.

"Uma das objeções à teoria clássica é que ela supõe o trabalho como único e universal fator de produção e que este é dotado de completa mobilidade" (SOARES, 2004, p. 38). Segundo Soares (2004), em 1933, Gottfried Harbeler utilizou a curva de possibilidades da produção e desenvolveu o conceito de custos de oportunidade (a quantidade que se deixa produzir de determinada mercadoria quando se produz uma unidade de outra). Isso permitiu a introdução de outros fatores de produção sem destruir a lógica das vantagens comparativas.

A teoria de comércio apresentada anteriormente não constitui a única explicação para as vantagens comparativas das nações. Existem outros modelos, entre os quais destaca-se o modelo neoclássico de Hecksher-Ohlin-Samuelson. No começo do século XX, dois economistas suecos, Eli Heckscher e Bertil Ohlin desenvolveram uma teoria de comércio internacional que destacava as diferenças internacionais entre dotações de categorias abrangentes de fatores produtivos: trabalho, capital e terra (CAVES: FRANKEL; JONES, 2001). Segundo o modelo Heckscher-Ohlin, cada país exporta a mercadoria que utiliza mais intensivamente o fator produtivo mais abundante internamente (JAYME JR., 2001). Assim, o principal fundamento dos trabalhos de Hecksher e Ohlin é o de que as nações trocam mercadorias porque não podem comercializar os fatores de produção (SOARES, 2004).

Em 1950 o economista Wassily Leontief realizou o teste empírico do teorema de Hecksher e Ohlin, partindo da hipótese de que os Estados Unidos são um país abundante em capital e, portanto, deveriam exportar mais bens de capital (SOARES, 2004). A constatação de seu trabalho foi que os Estados Unidos eram exportadores de mercadorias trabalho-intensivas 
(paradoxo de Leontief) e somente em 1970, quando foram introduzidos os fatores de produção petróleo e energia, provou-se que os Estados Unidos eram um país abundante em capital.

O teorema Stolper-Samuelson generaliza o modelo Heckscher-Ohlin, analisando os efeitos do comércio internacional sobre o emprego e a distribuição de renda. Segundo esse modelo, "a liberalização comercial é uma importante política para os países em desenvolvimento aumentarem concomitantemente sua taxa de crescimento e os salários reais" (JAYME JR., 2001, p. 72).

Enquanto o modelo ricardiano considerava as diferenças de tecnologia entre os países como base do comércio exterior, a teoria de Heckscher-OhlinSamuelson concentra-se nas diferenças nas dotações domésticas dos fatores de produção e na diferença na intensidade do uso de fatores na produção de diferentes produtos nesses países. Nesse caso o custo de produção de cada mercadoria é determinado endogenamente e será diferente para países distintos em autarquia, mesmo que todos tenham acesso à mesma tecnologia. (GONÇALVES et al, 1998, p. 18)

Ainda de acordo com Gonçalves et al (1998), além do Teorema de Heckscher-Ohlin e do Teorema de Stolper-Samuelson outras duas proposições englobam resultados fundamentais da pura teoria de comércio internacional: o Teorema de Equalização do Preço dos Fatores e o Teorema de Rybczynski.

Para Gonçalves et al (1998), o Teorema da Equalização do Preço dos Fatores afirma que: (1) em sua dimensão externa, sob certas condições, será suficiente o livre comércio de bens finais para a equalização dos preços dos fatores internacionalmente; e (2) em sua dimensão interna, com o preço constante das mercadorias, uma pequena mudança na dotação de um fator de produto não afetará o preço dos fatores. De acordo com Soares (2004), esse teorema demonstra que o comércio internacional, é igual à remuneração dos fatores de produção entre os diversos países. 
Pelo Teorema Rybczynski, se o preço de um produto for fixo, um aumento na dotação de um fator acarreta um crescimento mais que proporcional na produção da mercadoria que usa o fator relativamente de forma intensiva e uma queda absoluta da produção da outra mercadoria (GONÇALVES et al, 1998).

A evolução do comércio internacional nos últimos cinqüenta anos não seguiu as previsões dos modelos apresentados anteriormente. Novas teorias surgiram para explicar novas tendências de comércio entre países. Um dos precursores da nova teoria do comércio foi Staffan Linder, que apresentou uma explicação para a crescente importância do comércio entre países ricos em contraposição à teorias que previam intensificação do comércio entre países ricos e pobres (GREMAUD et al, 2003). Linder (1961) analisou questões sobre as forças que determinavam o comércio de manufaturados entre os países, considerando que a decisão de produzir ou investir em uma mercadoria depende das possibilidades de lucro dos empresários, esforços de inovação e necessidades de contato entre produtor e consumidor. Para Linder:

[...] os produtos com maiores vantagens comparativas na exportação são aqueles cuja demanda no mercado doméstico do país fabricante é representativa, isto é, aquela que torna o produto potencialmente de exportação. [...] Nesse sentido, antes de avaliar o fluxo de comércio entre dois países é necessário verificar sua estrutura de demanda doméstica. E a demanda interna de um país depende, basicamente, do seu nível de renda per capita. (SOARES, 2004, p.46-47)

Segundo Soares (2004), Raymond Vernon apontava carência de teorias modernas capazes de explicar as novas formas de comércio entre os países, e propôs uma análise que se sustenta menos nos custos comparativos e privilegia o ritmo do fluxo de inovações, os efeitos da economia de escala e os papéis da ignorância e incerteza sobre a determinação dos padrões de comércio. 
Vernon desenvolveu a Teoria do Ciclo de Vida do Produto, que procurava explicar o comércio internacional com base no progresso tecnológico e nas várias etapas de vida de um produto, e a dinâmica da inovação nas corporações transnacionais (VERNON, 1966; GREMAUD et al, 2003 e GONÇALVES et al, 1998). De acordo com Soares (2004, p. 53), a principal contribuição de Vernon foi "mostrar como os estágios do processo de produção de uma mercadoria determinam os fluxos do comércio internacional e a mobilidade do investimento externo entre os países desenvolvidos e subdesenvolvidos”.

Krugman incorpora mais realismo ao modelo de Hecksher-Ohlin ao considerar que os mercados são imperfeitos e que sob essas circunstâncias algumas empresas podem formar e influenciar preços (SOARES, 2004). Porter (1989) e Soares (2004) corroboram essa idéia ao considerar que a estratégia de atuação das empresas de um país influencia a competitividade global de uma nação, criando vantagem competitiva.

Outro modelo importante que trata a relação entre comércio e crescimento é o modelo Bagwhati, no qual o bem-estar de uma nação se reduz como resultado de um processo de crescimento econômico estimulado pelo progresso tecnológico (JAYME JR., 2001). Segundo o autor, esse resultado é conseqüência da deterioração dos temos de troca em uma medida suficiente para compensar os impactos positivos do crescimento sobre o bem-estar a preços relativos constantes.

Grosman e Helpman (1990) apresentam um modelo de comércio e crescimento dinâmico, em que o crescimento deve levar em conta o acúmulo de conhecimento. Esse modelo gera uma taxa endógena de crescimento de longo prazo que relaciona comércio e crescimento por intermédio da difusão tecnológica e do conhecimento. 
Outras considerações recentes sobre comércio e desenvolvimento tem duas matrizes principais: a tese de Prebisch-Singer (PREBISCH, 1950; SINGER, 1950) sobre a deterioração dos termos de troca e a tese de Nurkse $(1957,1962)$ sobre o comércio como motor do desenvolvimento. Nurkse sustenta que o comércio foi o motor do crescimento econômico no século XIX e que isso foi possível porque a Inglaterra tinha propensão marginal a importar, gerando como subproduto de seu dinamismo industrial um grande mercado para matérias primas e alimentos, permitindo um rápido crescimento das economias da periferia que forneciam esses insumos. Essa visão foi contestada por Irving Kravis que argumentou que o crescimento foi resultado de um desenvolvimento econômico endógeno bem sucedido (GONÇALVES et al 1998).

\subsubsection{O BRASIL E O COMÉRCIO INTERNACIONAL}

O Brasil apresenta grandes desafios ao crescimento sustentado. As restrições ao crescimento estão ligadas, em parte, à questão externa. “As opções de ajuste ante o déficit em conta corrente e as restrições que impõe ao crescimento econômico necessitam ter por referência os setores que contribuem para o resultado da balança comercial" e nesse sentido o ajuste deveria centrar-se na expansão das exportações (CAVALCANTI; FRISCHTAK, 2001, p. 26).

De acordo com Gremaud, Vasconcellos e Toneto Jr. (2006, p. 552), “em termos comerciais, o histórico caráter agro-exportador do país fazia com que as exportações e importações tivessem elevada participação na renda nacional". Contudo, com a Grande Depressão e com a 
mudança de governo no Brasil, o processo de industrialização foi estimulado, em detrimento do modelo agroexportador.

A Grande Depressão, que atingiu a economia mundial na década de 1930, é considerada o marco fundamental do processo de consolidação da produção industrial brasileira e mesmo latino-americana. Embora o início do processo de industrialização brasileiro remonte às últimas décadas do século XIX, a indústria só viria a se tornar o fator determinante da dinâmica econômica na década de 30. [...] A literatura sobre a industrialização brasileira sintetizou esse rico processo histórico na expressão processo de industrialização de substituição de importações. (REGO; MARQUES, 2006, p.70)

Segundo Rego e Marques (2003), o Processo de Substituição de Importações (PSI) durou, aproximadamente de 1930 até o final da década de 70. Pelo processo de substituição de importações ocorre o crescimento da produção industrial com expansão da demanda interna, simultaneamente a uma redução da participação relativa das importações no produto industrial. Esse modelo de industrialização, adotado pelo Brasil e também por alguns países da América Latina, visava atender a demanda interna, gerar renda e empregos e promover o crescimento (GREMAUD; VASCONCELLOS; TONETO JR., 2006). Contudo, nesse período, apesar da redução do comércio internacional observada pelo coeficiente de abertura comercial (exportações mais importações em relação ao PIB), houve a necessidade de importação de máquinas e equipamentos para ampliar a capacidade de produção.

O saldo da balança comercial apresenta crescimento na década de 80. Apesar de serem dados positivos, o saldo da balança comercial brasileira no período deve ser analisado com cautela. De acordo com Araújo Jr. (1996, p.76), com relação à evolução da balança comercial dos países latino-americanos na década de 80, os superávits foram resultado do dramático esforço realizado na região para enfrentar a crise da dívida externa. $\mathrm{O}$ autor ainda argumenta que o saldo da balança comercial não pode ser utilizado como indicador de competitividade, pois pode indicar alguma fragilidade econômica. A seguir, o gráfico 3.1 apresenta o coeficiente de abertura comercial e a evolução do saldo da balança comercial entre 1950 e 2005. 


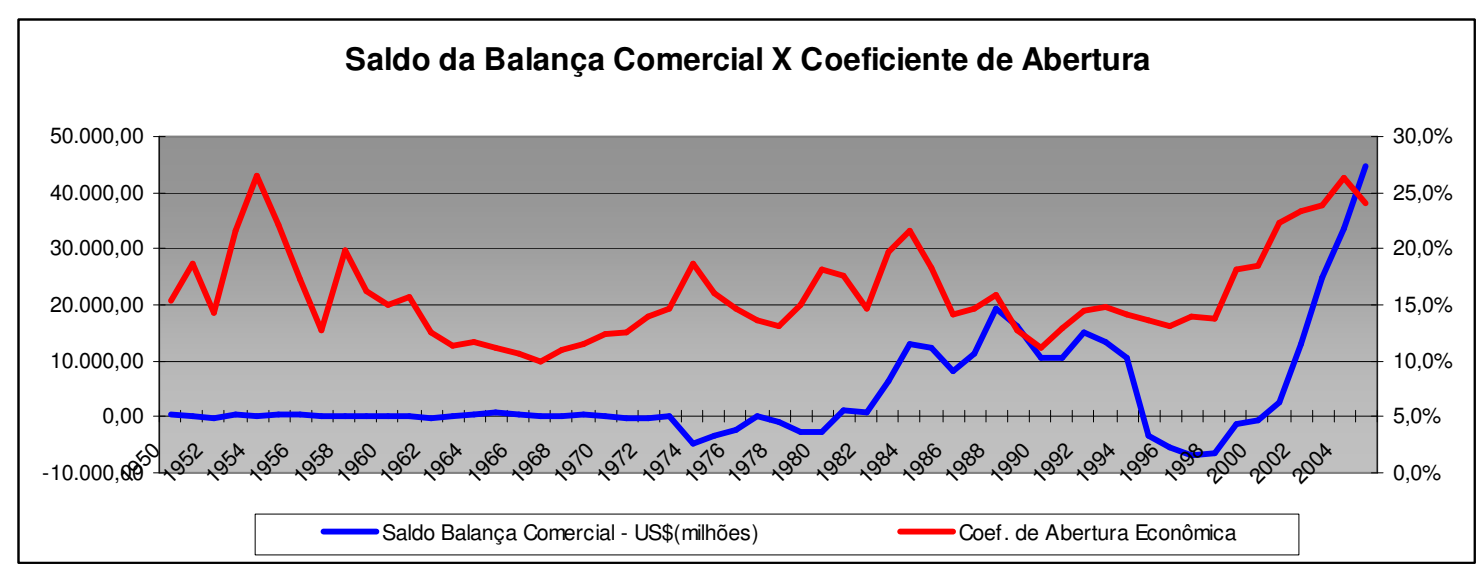

Gráfico 3.1 - Saldo da Balança Comercial e Coeficiente de Abertura (1950-2005)

Segundo Gremaud, Vasconcellos e Toneto Jr. (2006), após o rompimento completo do fluxo de recursos voluntários aos países em desenvolvimento em 1982, esses países foram obrigados a entrar em uma política de geração de superávits externos para fazer frente ao serviço da dívida. No Brasil, esse processo iniciou-se de forma voluntária em 1980 e aprofundou-se a partir de fins de 1982 sob a tutela do Fundo Monetário Internacional (FMI), para garantir o pagamento da dívida externa. A política adotada, dentre outras medidas, incluía intensa desvalorização real do cruzeiro (estimulando exportação), subsídios e incentivos à exportação, estímulo à competitividade da indústria brasileira, redução de investimentos, restrição ao crédito e redução do salário real (GREMAUD; VASCONCELLOS; TONETO JR., 2006).

Com a abertura comercial iniciada no fim da década de 80, aboliram-se diversos regimes especiais de importação, reduziu-se a redundância tarifária, além das alíquotas (GREMAUD; VASCONCELLOS; TONETO JR., 2006, p. 553). Dessa forma, as importações foram estimuladas. 
Um primeiro problema foi sentido pelas indústrias nacionais que não estavam preparadas para a concorrência com produtos estrangeiros. Durante o governo Collor, além de se extinguirem muitas barreiras comerciais não-tarifárias, definiu-se um programa de diminuição sobre tarifas de importação. Esse estímulo às importações teve influência no saldo da balança comercial.

No período de 1995 a 1999, houve uma queda acentuada no saldo da balança comercial. Isso se deu no período de implantação do Plano Real em que, dentre outras medidas, foi adotado o câmbio fixo (baseado em faixas cambiais). A paridade cambial fez com que o Real ficasse valorizado, estimulando importações e desestimulando exportações. De acordo com Gonçalves (1996), o impacto mais evidente da apreciação cambial se dá sobre o comércio exterior. De acordo com o autor, uma mudança nos preços externos, via apreciação real, favorece as importações e prejudica as exportações (GONÇALVES, 1996, p. 156).

Em 1999 há uma reversão nesse quadro. Com a adoção do câmbio flutuante no segundo mandato do presidente Fernando Henrique Cardoso, o Real foi se desvalorizando e com isso as exportações foram estimuladas em detrimento das importações. Com isso o saldo da balança comercial tem aumentado a cada ano a partir de 1999, como visto no gráfico 3.1.

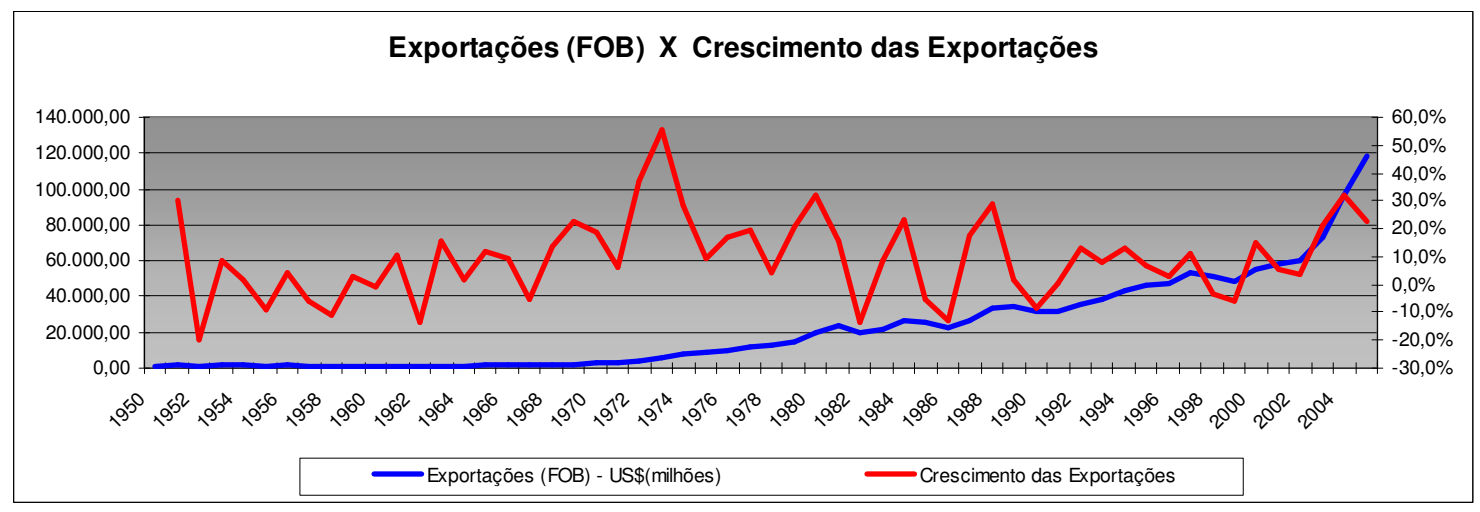

Gráfico 3.2 - Relação entre o montante e o crescimento das Exportações 
Pode-se verificar no gráfico 3.2 que as exportações aumentaram constantemente a partir da década de 70. Segundo dados do Banco Central, o crescimento médio na década de 70 foi de $22,93 \%$ contra $8,54 \%$ da década de 60 . Com a crise da década de 80 , o crescimento médio das exportações foi de 5,56\%. A partir do fim da década de 80 , três momentos são considerados importantes para as exportações: a abertura comercial de 1990, a adoção do câmbio fixo em 1994 e a mudança na política cambial em 1999. A partir de 1999 o crescimento anual médio das exportações foi de 16,64\% (1999-2005). Como já foi discutido, o aumento das exportações no fim da década de 90 é favorecido pela política cambial adotada no segundo mandato do presidente Fernando Henrique Cardoso.

Outra consideração importante a ser feita é em relação ao padrão de exportações brasileiro. Na década de 70, as exportações de produtos básicos era muito superior à exportação de produtos manufaturados. Esse quadro foi revertido com o passar do tempo. Segundo Prebisch (1950) e Singer (1950), os países periféricos, produtores de matérias-primas de menor valor agregado, ficariam sempre dependentes dos países centrais, produtores de bens industrializados. Assim, a análise do padrão de exportações brasileiro se faz importante. A seguir, o gráfico 3.3 apresenta a evolução das exportações brasileiras por classe de produto.

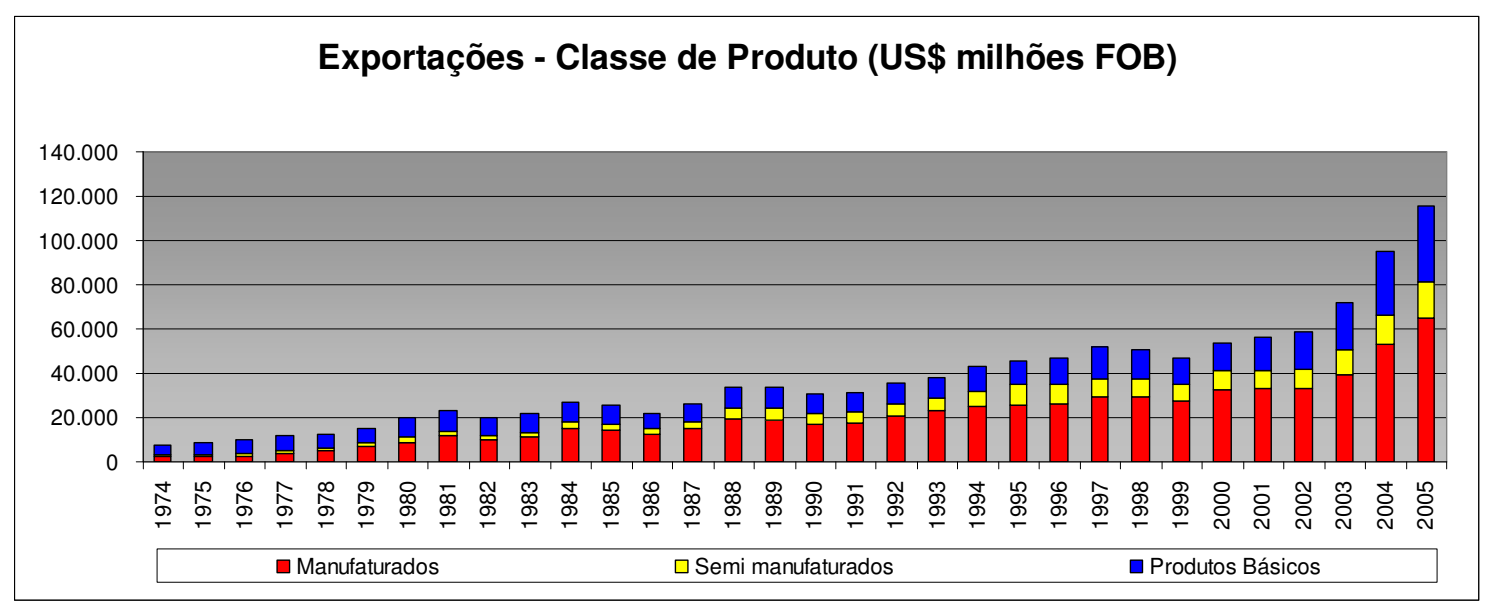

Gráfico 3.3 - Exportações por classe de produto (1974-2005 - em US\$) 
Pode-se observar pelo gráfico 3.3 que, no período analisado, as exportações brasileiras sofreram uma mudança de padrão. Em 1974 o Brasil exportava aproximadamente $60 \%$ de produtos básicos contra 30\% de produtos manufaturados. Esse padrão mudou e em 2005 o quadro praticamente inverteu. Nesse ano o Brasil exportou aproximadamente $60 \%$ de produtos manufaturados e $30 \%$ de produtos básicos, conforme apresenta o gráfico 3.4.

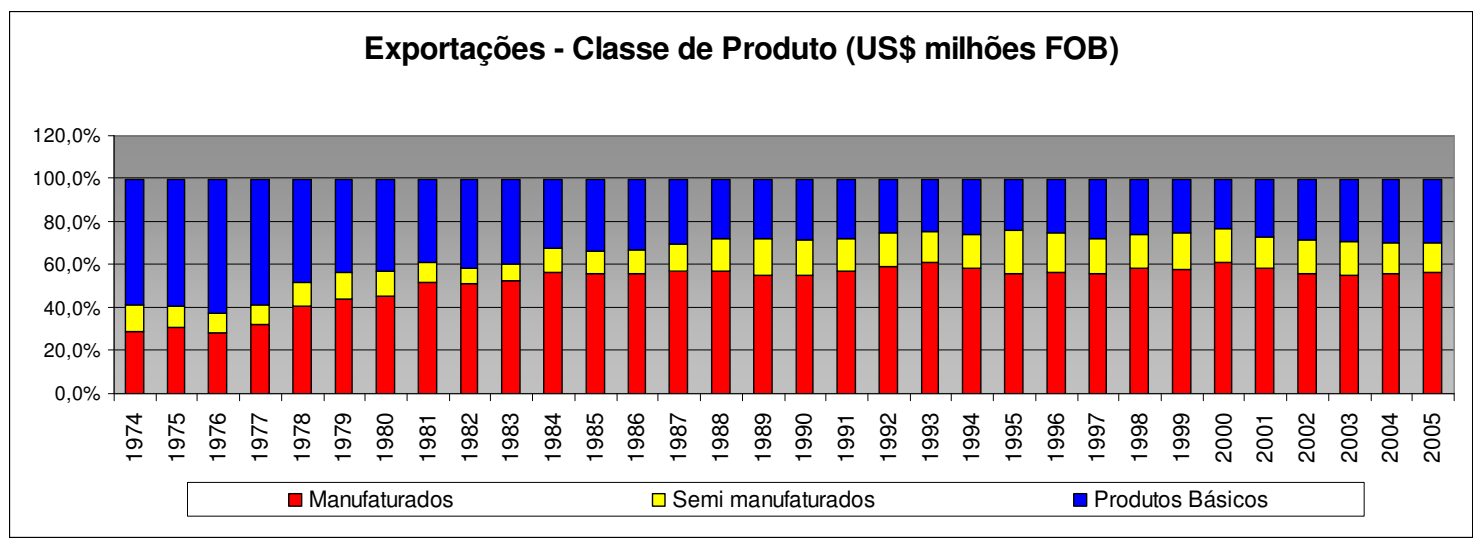

Gráfico 3.4 - Exportações por classe de produto (1974-2005 - em \%)

Ao analisar o padrão de exportações por categoria de uso, percebe-se que os principais componentes da exportação brasileira são os bens de consumo não duráveis e os bens intermediários (aço, carvão, cimento, zinco, etc.), e mais recentemente os bens de capital (que são utilizados no setor produtivo - máquinas, ferramentas, insumos).

A seguir os gráfico 3.5 e 3.6 apresentam as exportações por categoria de uso. De acordo com o gráfico 3.5 é possível observar o aumento das exportações, contudo, analisando o gráfico 3.6, percebe-se que há uma redução no percentual de exportação de bens intermediários. Por outro lado, a participação na pauta de exportações de bens de consumo duráveis, bens de capital e combustíveis aumentou. 


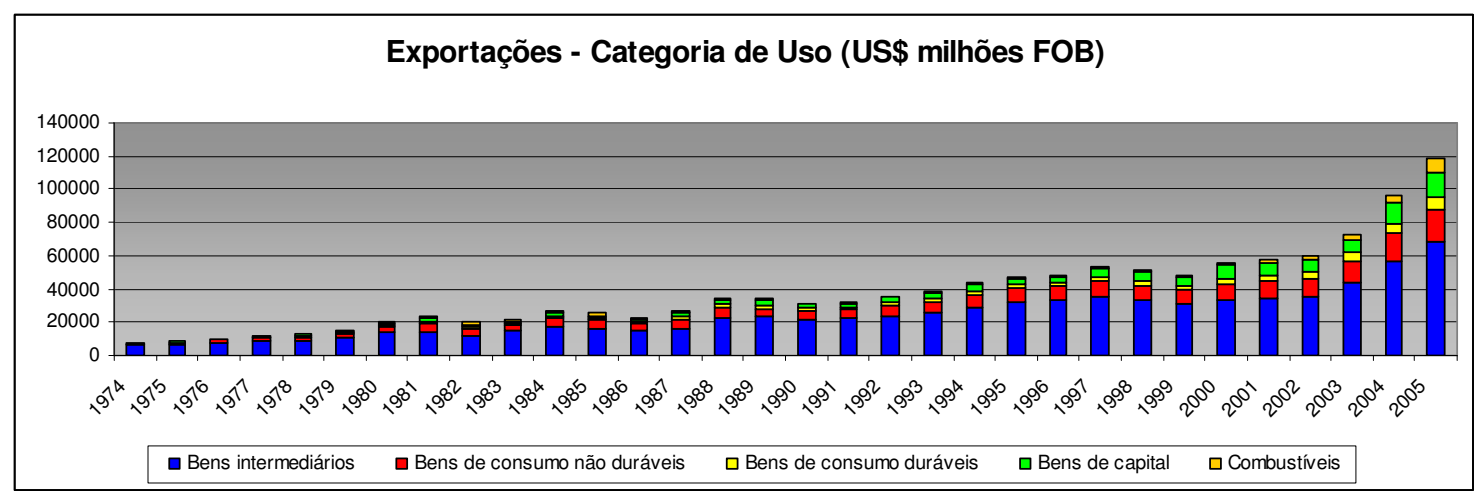

Gráfico 3.5 - Exportações por categoria de uso (1974-2005 - em US\$)

O gráfico 3.6 apresenta a participação percentual das categorias de uso na pauta de exportações. A primeira importante observação é que houve redução na exportação de bens intermediários, de 77,3\% em 1974 para 57,6\% em 2005. Outra categoria que apresentou mudanças significativas foram os bens de capital, que aumentaram de $3,3 \%$ para $13,1 \%$. Por fim, as exportações de combustíveis também aumentaram, de 1,7\% em 1974 para 6,6\% em 2005. A participação de bens de consumo não-duráveis permaneceu praticamente constante e a participação de bens de consumo duráveis aumentou de 2,5\% para 5,9\%

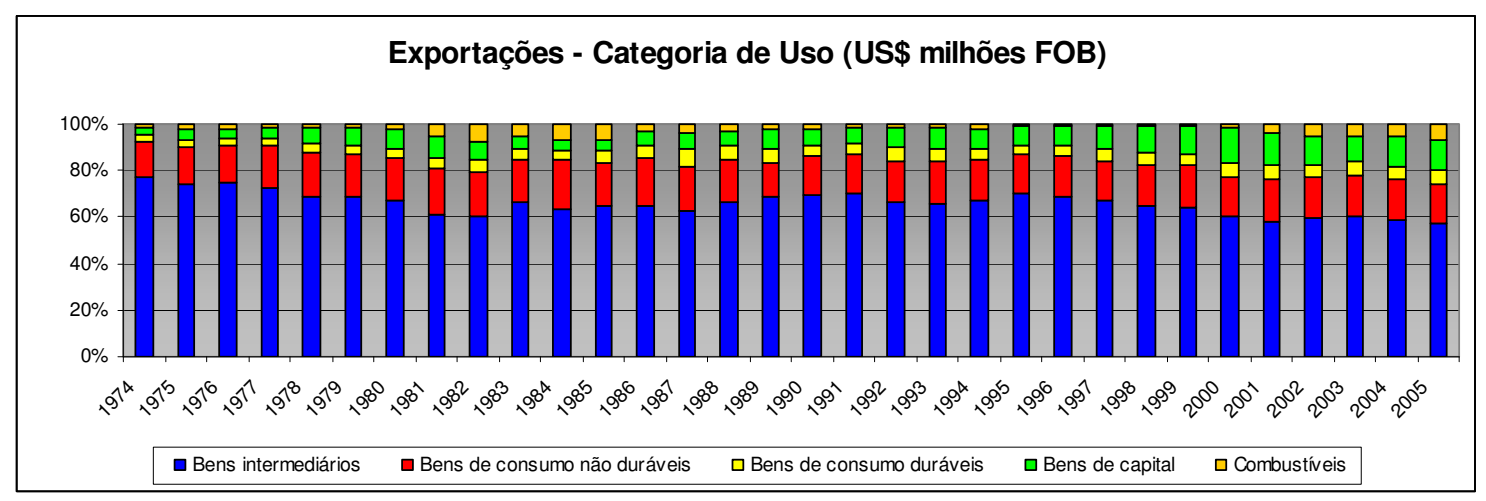

Gráfico 3.6 - Exportações por categoria de uso (1974-2005 - em \%) 


\section{ESTUDOS TEÓRICOS E EMPÍRICOS}

Muitos estudos foram realizados abordando questões relativas ao comércio internacional, crescimento e desenvolvimento econômico. Como visto nas seções anteriores, em cada contexto histórico e econômico se desenvolveram teorias para tentar explicar e promover alternativas de crescimento e desenvolvimento.

Assim, como parte da revisão bibliográfica, nesta seção estão relacionados alguns estudos sobre comércio internacional, crescimento e desenvolvimento econômico. Também nesta seção são apresentados os indicadores sugeridos na revisão bibliográfica.

\subsection{COMÉRCIO INTERNACIONAL, CRESCIMENTO E DESENVOLVIMENTO}

A relação entre comércio internacional e crescimento econômico tem sido objeto de estudo nas ciências econômicas há muito tempo, porém há pouca evidência sobre o papel do comércio no crescimento e desenvolvimento econômicos (JAYME JR., 2001). As mudanças ocorridas no fim da década de 80 e a abertura comercial proporcionada pela globalização estimularam estudos acerca dos efeitos do comércio sobre o investimento, crescimento e desenvolvimento.

Alguns modelos indicam que o crescimento econômico pode ter efeitos sobre os padrões de comércio internacional (JAYME JR., 2001), sem evidenciar, contudo, relações de causaefeito. 
Diversos autores estudaram as relações entre comércio e crescimento sob diferentes focos. Jayme Jr. (2001), Matos (2002, 2003) e Medina-Smith (2001) relacionaram uma série de estudos realizados envolvendo crescimento, desenvolvimento e comércio internacional.

Jayme Jr. (2001) relaciona artigos sobre comércio internacional e crescimento. A seguir, são inseridos no quadro 4.1 os estudos e a descrição desses estudos:

\begin{tabular}{|c|c|}
\hline ESTUDOS & DESCRIÇÃO DO ESTUDO \\
\hline $\begin{array}{l}\text { Bhagwati (1958); Edwards (1992); Edwards (1993); Sachs, } \\
\text { Warner (1995); Krueger (1997); Edwards (1998); } \\
\text { Srinivasan, Bhagwati (1999) }\end{array}$ & $\begin{array}{l}\text { Autores tentam demonstrar que economias abertas } \\
\text { tendem a convergir mais rapidamente a um } \\
\text { equilíbrio do que economias fechadas. }\end{array}$ \\
\hline $\begin{array}{l}\text { Taylor (1993); Helleiner (1996); McCombie, Thirlwall } \\
\text { (1999); Blecker (1999); Ben-David, Kimhi (2000) }\end{array}$ & $\begin{array}{l}\text { Autores acreditam que a abertura da economia pode } \\
\text { impedir o crescimento econômico devido aos efeitos } \\
\text { da abertura sobre a indústria incipiente ou sobre os } \\
\text { efeitos na Balança de Pagamentos. }\end{array}$ \\
\hline $\begin{array}{l}\text { Rodrik (1999); Rodríguez, Rodrik (1999); Harrison, } \\
\text { Hanson (1999) }\end{array}$ & $\begin{array}{l}\text { Autores são céticos quanto à capacidade de a } \\
\text { abertura estimular o crescimento econômico, mesmo } \\
\text { utilizando metodologias similares às utilizadas pelos } \\
\text { defensores dos benefícios da abertura. }\end{array}$ \\
\hline $\begin{array}{l}\text { Taylor (1991); Sachs, Warner (1995); Easterly, Loyaza, } \\
\text { Montiel. (1996); Bleaney (1997); Frenkel (1998); Ocampo, } \\
\text { Taylor (1998); Frankel, Romer (1999); Ros, Lustig (1999) }\end{array}$ & $\begin{array}{l}\text { Estudos sobre os efeitos da liberação comercial } \\
\text { sobre o crescimento. }\end{array}$ \\
\hline
\end{tabular}

Quadro 4.1 - Crescimento Econômico e Comércio Internacional (JAYME JR, 2001)

A experiência de crescimento econômico promovido por exportações tem apoiado a hipótese teórica de que a abertura do comércio exterior é um mecanismo para obtenção de crescimento eficiente e rápido e de melhoria da alocação de recursos domésticos (GILES; WILLIANS, 2000). O caso dos países asiáticos é um exemplo do modelo de crescimento e desenvolvimento econômico promovido pelas exportações (export-led). Para Stiglitz e Walsh (2003) esse modelo de crescimento é um fator que distingue os países do leste asiático dos países menos desenvolvidos. 
Matos (2003), no quadro 4.2, relaciona os seguintes artigos que abordam questões sobre comércio internacional e crescimento:

\begin{tabular}{|c|c|}
\hline ESTUDO & DESCRIÇÃO DO ESTUDO / CONCLUSÕES \\
\hline Prebisch (1950) e Singer (1950) & $\begin{array}{l}\text { Sustentam a estratégia contrária de desenvolvimento com base em } \\
\text { protecionismo ou substituição de importações por meio de políticas } \\
\text { tarifárias, cotas e subsídios. }\end{array}$ \\
\hline Kindleberger (1961) & $\begin{array}{l}\text { Observa que a retração ou a expansão do comércio externo pode ter } \\
\text { impactos sobre o crescimento, mas a relação entre comércio e crescimento } \\
\text { é complexa. }\end{array}$ \\
\hline Feder (1982) & $\begin{array}{l}\text { Observa que o crescimento do setor exportador pode transmitir estímulos } \\
\text { ao crescimento da economia em geral, visto que a produtividade marginal } \\
\text { de fatores pode ser mais elevada no setor de exportação do que no resto da } \\
\text { economia. }\end{array}$ \\
\hline Tyler (1982) & $\begin{array}{l}\text { Decompõe as fontes de crescimento da demanda da indústria de } \\
\text { transformação brasileira. Conclui que as exportações contribuíram para o } \\
\text { crescimento do produto total da indústria. }\end{array}$ \\
\hline Adelman (1984) & $\begin{array}{l}\text { Duvida da capacidade dos mercados dos países desenvolvidos de absorver } \\
\text { mais exportações dos países em desenvolvimento (impedindo essa via de } \\
\text { desenvolvimento). }\end{array}$ \\
\hline Jaffee (1985) & $\begin{array}{l}\text { Observa que a hipótese do crescimento conduzido pelas exportações não é } \\
\text { universal, ressaltando as dificuldades da manutenção desse crescimento em } \\
\text { longo prazo em países menos desenvolvidos. }\end{array}$ \\
\hline Jung; Marshall (1985) & $\begin{array}{l}\text { Obtiveram resultados duvidosos sobre a validade da hipótese de que as } \\
\text { exportações levam ao crescimento econômico. }\end{array}$ \\
\hline Chow (1987) & $\begin{array}{l}\text { Testou a hipótese de que as exportações afetam o crescimento econômico } \\
\text { com dados de } 8 \text { países. Conclui que existe ausência de causalidade na } \\
\text { Argentina, causalidade unidirecional no México e causalidade bidirecional } \\
\text { para os demais países. }\end{array}$ \\
\hline Pinheiro (1992) & $\begin{array}{l}\text { Analisa os impactos que a promoção das exportações brasileiras gera sobre } \\
\text { o crescimento da produtividade total de fatores produtivos por meio de } \\
\text { progresso tecnológico. Para a identificação dos impactos é necessária a } \\
\text { inclusão de uma série de condições. }\end{array}$ \\
\hline Thenuwara (1994) & $\begin{array}{l}\text { Observa que, em decorrência das externalidades, o conhecimento é } \\
\text { adquirido pelos agentes ligados ao comércio externo de um país isolado por } \\
\text { vários meios (revistas, conversas, workshops e protótipos). }\end{array}$ \\
\hline Ahmad; Harnhirun (1996) & $\begin{array}{l}\text { Testaram a causalidade entre exportações e crescimento econômico para } \\
\text { cinco países membros da ASEAN e concluíram que o crescimento } \\
\text { econômico leva as exportações a crescer, mas as exportações parecem não } \\
\text { causar crescimento em Granger. }\end{array}$ \\
\hline Findlay; Watson (1996) & $\begin{array}{l}\text { Analisa a hipótese teórica de que a abertura do comércio é um mecanismo } \\
\text { para obtenção do crescimento econômico eficiente e rápido, e de melhoria } \\
\text { da alocação de recursos domésticos. }\end{array}$ \\
\hline Canuto (1998) & $\begin{array}{l}\text { Expõe um modelo teórico sobre a interação entre comércio exterior e } \\
\text { crescimento com restrição de divisas. }\end{array}$ \\
\hline Yamada (1998) & $\begin{array}{l}\text { Observa aspectos benéficos que têm sido ressaltados para explicar a } \\
\text { relação causal entre exportações e crescimento, destacando economias de } \\
\text { escala, incentivos à introdução de mudança tecnológica e eficiência de } \\
\text { externalidades. }\end{array}$ \\
\hline Fasano Filho (1988) & $\begin{array}{l}\text { Analisou o impacto das exportações de manufaturados sobre o crescimento } \\
\text { da economia. Resultados mostram que as taxas de crescimento econômico } \\
\text { mais elevadas estavam associadas à maiores taxas de exportações de } \\
\text { manufaturados. }\end{array}$ \\
\hline
\end{tabular}




\begin{tabular}{|c|c|}
\hline Hatemi-J; Irandoust (2000) & $\begin{array}{l}\text { Observam que as exportações, ao possibilitar aumentos de importações de } \\
\text { bens intermediários e de capitais e ao intensificar a competição, abrandam } \\
\text { o comprometimento das restrições ao intercâmbio externo. }\end{array}$ \\
\hline Morley; Perdikis (2000) & $\begin{array}{l}\text { Argumentam que o impacto das exportações sobre o produto tem origem } \\
\text { na geração de externalidades, que funcionam por meio de retornos } \\
\text { crescentes de escala e de outros fatores positivos, como adoção de } \\
\text { tecnologias, técnicas de administração e novos produtos. }\end{array}$ \\
\hline Giles; Williams (2000) & $\begin{array}{l}\text { Analisa a experiência dos países da Ásia que, apoiados no crescimento } \\
\text { baseado nas exportações, dobraram seu padrão de vida a cada dez anos. } \\
\text { Autores identificam medidas de estímulo ao comércio exterior como } \\
\text { instrumentos-chave de política econômica }\end{array}$ \\
\hline Silva; Virgolino; Lima (2000) & $\begin{array}{l}\text { Não identificam relação de longo prazo entre exportações e crescimento } \\
\text { econômico. }\end{array}$ \\
\hline Kónya (2000) & $\begin{array}{l}\text { Analisou dados de } 25 \text { países da OCDE e concluiu que os resultados obtidos } \\
\text { dão suporte à hipótese de que as exportações levam ao crescimento } \\
\text { somente na Bélgica e Islândia. Evidências de causalidade de Granger no } \\
\text { Canadá e Japão, e constatação de impactos bidirecionais na Suécia e Reino } \\
\text { Unido. }\end{array}$ \\
\hline Richards (2001) & $\begin{array}{l}\text { Analisou as exportações como determinantes do crescimento econômico de } \\
\text { longo prazo no Paraguai. A hipótese de que as exportações levam ao } \\
\text { crescimento não teve muita relevância empírica. }\end{array}$ \\
\hline Bresser-Pereira;Nakano (2002) & $\begin{array}{l}\text { Autores analisam as relações entre crescimento econômico e exportações, } \\
\text { considerando as restrições estruturais que limitam o impacto das } \\
\text { exportações sobre o crescimento. }\end{array}$ \\
\hline Zestos; Tao (2002) & $\begin{array}{l}\text { Argumentam que a expansão das exportações permite que os países sigam } \\
\text { um caminho mais veloz em direção à industrialização e ao crescimento } \\
\text { econômico (utilizando fundamentos de economia de escala) }\end{array}$ \\
\hline
\end{tabular}

Quadro 4.2 - Crescimento Econômico e Exportações (MATOS, 2003)

Medina-Smith (2001) também contribui com este levantamento bibliográfico ao analisar estudos que envolvem o tema pesquisado nesta dissertação. Em seu trabalho o autor apresenta estudos, de 1967 a 1998, que buscam avaliar a hipótese do crescimento liderado por exportações.

Nesse trabalho, Medina-Smith lista os autores, a amostra, o período de estudo, o tratamento estatístico para a série de dados, os indicadores de crescimento econômico, os indicadores de exportação, a técnica econométrica utilizada, outras variáveis e as conclusões de cada trabalho. 
Dessa forma, o levantamento de Medina-Smith (2001) pode ser sintetizado no quadro 4.3.

\begin{tabular}{|c|c|c|}
\hline ESTUDO & DADOS & CONCLUSÕES \\
\hline $\begin{array}{l}\text { Emery } \\
(1967)\end{array}$ & $\begin{array}{l}\text { Amostra - } 50 \\
\text { Período de Estudo - 1953-1963 (médias) } \\
\text { Série de Dados - Cross-section (corte transversal) } \\
\text { Crescimento Econômico - Crescimento do PNB } \\
\text { Exportação - Crescimento das Exportações } \\
\text { Técnica Econométrica - Estimadores de Mínimos Quadrados } \\
\text { Outras Variáveis - Conta Corrente }\end{array}$ & $\begin{array}{l}\text { Aceita (confirma) a } \\
\text { hipótese do crescimento } \\
\text { conduzido pela exportação. }\end{array}$ \\
\hline $\begin{array}{l}\text { Syron; } \\
\text { Walsh } \\
(1968)\end{array}$ & $\begin{array}{l}\text { Amostra - } 50 \\
\text { Período de Estudo - 1953-1963 } \\
\text { Série de Dados - Cross-section (corte transversal) } \\
\text { Crescimento Econômico - Crescimento do PNB } \\
\text { Exportação - Exportação } \\
\text { Técnica Econométrica - Estimadores de Mínimos Quadrados }\end{array}$ & $\begin{array}{l}\text { Aceita (confirma) a } \\
\text { hipótese, mas os resultados } \\
\text { são sensíveis dependendo o } \\
\text { tipo de país analisado } \\
\text { (subdesenvolvidos e } \\
\text { desenvolvidos). }\end{array}$ \\
\hline $\begin{array}{l}\text { Serven } \\
(1968)\end{array}$ & $\begin{array}{l}\text { Amostra - 50 } \\
\text { Período de Estudo - 1953-1963 } \\
\text { Série de Dados - Cross-section (corte transversal) } \\
\text { Crescimento Econômico - Crescimento do PNB } \\
\text { Exportação - Crescimento das Exportações e/ou mudança na } \\
\text { exportação/produtividade } \\
\text { Técnica Econométrica - Estimadores de Mínimos Quadrados }\end{array}$ & $\begin{array}{l}\text { Aceita (confirma) a } \\
\text { hipótese e recomenda o uso } \\
\text { do crescimento das } \\
\text { exportações e mudança na } \\
\text { exportação/produtividade. }\end{array}$ \\
\hline $\begin{array}{l}\text { Kravis } \\
(1970)\end{array}$ & $\begin{array}{l}\text { Amostra - } 37 \\
\text { Período de Estudo - 1835-1966 } \\
\text { Série de Dados - Cross-section (corte transversal) } \\
\text { Crescimento Econômico - PNB } \\
\text { Exportação - Crescimento das Exportações } \\
\text { Técnica Econométrica - Coeficiente de correlação Spearman (com } \\
\text { ordenação) }\end{array}$ & $\begin{array}{l}\text { Confirma a hipótese do } \\
\text { crescimento baseado em } \\
\text { exportações, mas indica que } \\
\text { os países menos } \\
\text { desenvolvidos que são } \\
\text { capazes de diversificar suas } \\
\text { exportações tem mais } \\
\text { sucesso em crescimento. } \\
\end{array}$ \\
\hline $\begin{array}{c}\text { Michaely } \\
\text { (1977) }\end{array}$ & $\begin{array}{l}\text { Amostra - } 41 \\
\text { Período de Estudo - 1950-1973 } \\
\text { Série de Dados - Cross-section (corte transversal) } \\
\text { Crescimento Econômico - Crescimento do PNB per capita } \\
\text { Exportação - Crescimento da participação nas exportações } \\
\text { Técnica Econométrica - Coeficiente de correlação Spearman (com } \\
\text { ordenação) }\end{array}$ & $\begin{array}{l}\text { Aceita (confirma) a } \\
\text { hipótese de crescimento } \\
\text { baseado em exportações e } \\
\text { sugere a existência de um } \\
\text { efeito de limiar (threshold } \\
\text { effect }^{7} \text { ). }\end{array}$ \\
\hline $\begin{array}{c}\text { Balassa } \\
(1978)\end{array}$ & $\begin{array}{l}\text { Amostra - } 11 \\
\text { Período de Estudo - 1960-1973 } \\
\text { Série de Dados - Cross-section (corte transversal) } \\
\text { Crescimento Econômico - Crescimento real do PNB } \\
\text { Exportação - Crescimento real das Exportações } \\
\text { Técnica Econométrica - Coeficiente de correlação Spearman (com } \\
\text { ordenação), Estimadores de Mínimos Quadrados, Função Produção } \\
\text { Outras Variáveis - força de trabalho, investimento/produtividade }\end{array}$ & $\begin{array}{l}\text { Aceita (confirma) a } \\
\text { hipótese de crescimento } \\
\text { baseado em exportações. }\end{array}$ \\
\hline $\begin{array}{l}\text { Heller \& } \\
\text { Porter } \\
(1978)\end{array}$ & $\begin{array}{l}\text { Amostra - } 41 \\
\text { Período de Estudo - 1950-1973 } \\
\text { Série de Dados - Cross-section (corte transversal) } \\
\text { Crescimento Econômico - Taxa de crescimento do PNB } \\
\text { Exportação - Exportação per capita } \\
\text { Técnica Econométrica - Coeficiente de correlação Spearman (com } \\
\text { ordenação) }\end{array}$ & $\begin{array}{l}\text { Apóia fracamente que o } \\
\text { crescimento das } \\
\text { exportações gera } \\
\text { crescimento. }\end{array}$ \\
\hline
\end{tabular}

\footnotetext{
${ }^{7}$ Pode-se definir threshold effect (ou efeito limiar) como sendo o efeito que surge sobre o crescimento do
} produto per capita quando o número médio de anos de educação atinge uma certa magnitude (FREITAS; BACHA, 2004, p. 537-538) 


\begin{tabular}{|c|c|c|}
\hline $\begin{array}{l}\text { Fajana } \\
(1979)\end{array}$ & $\begin{array}{l}\text { Amostra - } 1 \\
\text { Período de Estudo - 1954-1974 (Nigéria) } \\
\text { Série de Dados - Séries Temporais } \\
\text { Crescimento Econômico - Crescimento do PIB } \\
\text { Exportação - Participação das exportações no PIB e mudança na } \\
\text { exportação/PIB } \\
\text { Técnica Econométrica - Estimadores de Mínimos Quadrados, } \\
\text { modelo de } 2 \text { Gaps } \\
\text { Outras Variáveis - Capital Estrangeiro }\end{array}$ & $\begin{array}{l}\text { Aceita (confirma) a } \\
\text { hipótese de que as } \\
\text { exportações promovem } \\
\text { crescimento e sugere que } \\
\text { isso é devido as alterações } \\
\text { em investimentos internos. }\end{array}$ \\
\hline $\begin{array}{c}\text { Tyler } \\
(1981)\end{array}$ & $\begin{array}{l}\text { Amostra - } 55 \text { \& } 49 \\
\text { Período de Estudo - 1960-1977 rendimento médio nos países } \\
\text { menos desenvolvidos } \\
\text { Série de Dados - Cross-section (corte transversal) } \\
\text { Crescimento Econômico - Crescimento real do PNB e PNB per } \\
\text { capita } \\
\text { Exportação - Crescimento real das Exportações } \\
\text { Técnica Econométrica - Coeficiente de correlação Pearson e } \\
\text { Spearman (com ordenação), Estimadores de Mínimos Quadrados, } \\
\text { Função produção } \\
\text { Outras Variáveis - crescimento da força de trabalho, aumento de } \\
\text { investimento }\end{array}$ & $\begin{array}{l}\text { Aceita (confirma) a } \\
\text { hipótese de que as } \\
\text { exportações promovem } \\
\text { crescimento e sugerem a } \\
\text { existência de um efeito de } \\
\text { limiar (threshold effect). }\end{array}$ \\
\hline $\begin{array}{c}\text { Feder } \\
(1983)\end{array}$ & $\begin{array}{l}\text { Amostra - } 32 \\
\text { Período de Estudo - 1964-1973 } \\
\text { Série de Dados - Cross-section (corte transversal) } \\
\text { Crescimento Econômico - Crescimento do PIB } \\
\text { Exportação - Crescimento das Exportações e mudança na } \\
\text { exportação/produtividade } \\
\text { Técnica Econométrica - Estimadores de Mínimos Quadrados, } \\
\text { função produção } \\
\text { Outras Variáveis - crescimento da força de trabalho, aumento de } \\
\text { investimento /produtividade }\end{array}$ & $\begin{array}{l}\text { Aceita (confirma) a } \\
\text { hipótese de que as } \\
\text { exportações promovem } \\
\text { crescimento. }\end{array}$ \\
\hline $\begin{array}{c}\text { Kavoussi } \\
\text { (1984) }\end{array}$ & $\begin{array}{l}\text { Amostra - } 73 \\
\text { Período de Estudo - 1960-1978 rendimento médio e baixo, países } \\
\text { menos desenvolvidos } \\
\text { Série de Dados - Cross-section (corte transversal) } \\
\text { Crescimento Econômico - Crescimento real do PIB } \\
\text { Exportação - Crescimento real das Exportações } \\
\text { Técnica Econométrica - Coeficiente de correlação Spearman (com } \\
\text { ordenação), Estimadores de Mínimos quadrados, função produção } \\
\text { Outras Variáveis - crescimento de atividade (trabalho), aumento do } \\
\text { capital }\end{array}$ & $\begin{array}{l}\text { Aceita (confirma) a } \\
\text { hipótese de que as } \\
\text { exportações promovem } \\
\text { crescimento, contudo, o } \\
\text { efeito tende a diminuir de } \\
\text { acordo com o nível de } \\
\text { desenvolvimento. }\end{array}$ \\
\hline $\begin{array}{c}\text { Balassa } \\
(1985)\end{array}$ & $\begin{array}{l}\text { Amostra - } 43 \\
\text { Período de Estudo - 1973-1979 países semi industrializados } \\
\text { Série de Dados - Cross-section (corte transversal) } \\
\text { Crescimento Econômico - Crescimento real do PNB } \\
\text { Exportação - Crescimento real das exportações } \\
\text { Técnica Econométrica - Estimadores de Mínimos Quadrados, } \\
\text { função produção } \\
\text { Outras Variáveis - poupança, atividade (trabalho), PIB per capita, } \\
\text { participação da exportação (produtos manufaturados) }\end{array}$ & $\begin{array}{l}\text { Aceita (confirma) a } \\
\text { hipótese de que as } \\
\text { exportações promovem } \\
\text { crescimento e sugere que a } \\
\text { orientação para o comércio } \\
\text { externo é benéfica. }\end{array}$ \\
\hline $\begin{array}{c}\text { Jung \& } \\
\text { Marshall } \\
(1985)\end{array}$ & $\begin{array}{l}\text { Amostra - } 37 \\
\text { Período de Estudo - 1950-1981 } \\
\text { Série de Dados - Países menos desenvolvidos Séries Temporais } \\
\text { Crescimento Econômico - PIB ou PNB real } \\
\text { Exportação - atraso real no crescimento das exportações } \\
\text { Técnica Econométrica - Estimadores de Mínimos Quadrados, teste } \\
\text { de causalidade de Granger } \\
\text { Outras Variáveis - atraso no PIB e PNB }\end{array}$ & $\begin{array}{l}\text { Apenas em } 4 \text { casos entre } 37 \\
\text { foram evidenciadas a } \\
\text { confirmação da hipótese de } \\
\text { que as exportações } \\
\text { promovem crescimento } \\
\text { (Indonésia, Egito, Costa } \\
\text { Rica e Equador). }\end{array}$ \\
\hline
\end{tabular}




\begin{tabular}{|c|c|c|}
\hline Ram (1985) & $\begin{array}{l}\text { Amostra - } 73 \\
\text { Período de Estudo - 1960-1970 1970-1977 rendimento baixo e } \\
\text { médio em países menos desenvolvidos } \\
\text { Série de Dados - Séries Temporais (dois sub-períodos) } \\
\text { Crescimento Econômico - Crescimento real do PIB } \\
\text { Exportação - Real Crescimento das Exportações } \\
\text { Técnica Econométrica - Estimadores de Mínimos Quadrados, teste } \\
\text { branco } \\
\text { Outras Variáveis - crescimento da força de trabalho e aumento no } \\
\text { investimento }\end{array}$ & $\begin{array}{l}\text { Aceita (confirma) a } \\
\text { hipótese de que as } \\
\text { exportações promovem } \\
\text { crescimento e sugere a } \\
\text { existência de um efeito de } \\
\text { limiar (threshold effect). }\end{array}$ \\
\hline $\begin{array}{l}\text { Chow } \\
(1987)\end{array}$ & $\begin{array}{l}\text { Amostra - 8 } \\
\text { Período de Estudo - 1960-1980 } \\
\text { Série de Dados - Séries temporais em países recentemente } \\
\text { industrializados } \\
\text { Crescimento Econômico - Aumento da produtividade da produção } \\
\text { Exportação - Crescimento das exportações de manufaturados } \\
\text { Técnica Econométrica - teste de causalidade de Sim's (1972), } \\
\text { modelo bivariado }\end{array}$ & $\begin{array}{l}\text { Aceita (confirma) a } \\
\text { hipótese de causalidade } \\
\text { recíproca com respeito ao } \\
\text { crescimento das } \\
\text { exportações e } \\
\text { desenvolvimento industrial. }\end{array}$ \\
\hline $\begin{array}{l}\text { Darrat } \\
(1987)\end{array}$ & $\begin{array}{l}\text { Amostra - } 4 \\
\text { Período de Estudo - 1955-1982 Tigres asiáticos } \\
\text { Série de Dados - Séries Temporais } \\
\text { Crescimento Econômico - Crescimento real do PIB } \\
\text { Exportação - Crescimento real das Exportações } \\
\text { Técnica Econométrica - Estimadores de Mínimos Quadrados, teste } \\
\text { branco, modelo bivariado }\end{array}$ & $\begin{array}{l}\text { Rejeita a hipótese de } \\
\text { crescimento baseado em } \\
\text { exportações em } 3 \text { dos } 4 \\
\text { casos. Confirma apenas no } \\
\text { caso da República da Coréia } \\
\text { com base no teste de } \\
\text { causalidade. }\end{array}$ \\
\hline $\begin{array}{l}\text { Heitger } \\
(1987)\end{array}$ & $\begin{array}{l}\text { Amostra - } 36 \\
\text { Período de Estudo - 1950-1970 } \\
\text { Série de Dados - Médias Cross-section (corte transversal) } \\
\text { Crescimento Econômico - Real PIB per capita } \\
\text { Exportação - Participação da exportação no PIB } \\
\text { Técnica Econométrica - Estimadores de Mínimos Quadrados, } \\
\text { função produção } \\
\text { Outras Variáveis - Investimento interno/PIB, taxa efetiva de } \\
\text { proteção, força de trabalho, adaptação tecnológica e alfabetização } \\
\text { em adultos }\end{array}$ & $\begin{array}{l}\text { Confirma o caso para } \\
\text { liberalismo comercial. }\end{array}$ \\
\hline Ram (1987) & $\begin{array}{l}\text { Amostra - } 88 \\
\text { Período de Estudo - 1960-1972 1973-1982 rendimento baixo e } \\
\text { médio em países menos desenvolvidos } \\
\text { Série de Dados - Cross-section (corte transversal) - } 2 \text { sub-períodos } \\
\text { Crescimento Econômico - Crescimento real do PIB } \\
\text { Exportação - crescimento real das Exportações } \\
\text { Técnica Econométrica - Estimadores de Mínimos Quadrados, } \\
\text { função produção } \\
\text { Outras Variáveis - tamanho do governo, Investimento/PIB, } \\
\text { aumento da mão de obra (trabalho) }\end{array}$ & $\begin{array}{l}\text { Aceita (confirma) a } \\
\text { hipótese de que as } \\
\text { exportações promovem } \\
\text { crescimento mas alerta para } \\
\text { as enormes diferenças e } \\
\text { diversidades entre países e } \\
\text { sugere cautela ao interpretar } \\
\text { resultados. }\end{array}$ \\
\hline $\begin{array}{l}\text { Moschos } \\
(1989)\end{array}$ & $\begin{array}{l}\text { Amostra - } 71 \\
\text { Período de Estudo - 1970-1980 } \\
\text { Série de Dados - Médias Cross-section (corte transversal) } \\
\text { Crescimento Econômico - Crescimento real do PIB } \\
\text { Exportação - Crescimento real das Exportações } \\
\text { Técnica Econométrica - Estimadores de Mínimos Quadrados, } \\
\text { função produção } \\
\text { Outras Variáveis - aumento da mão de obra (trabalho), crescimento } \\
\text { real do investimento interno }\end{array}$ & $\begin{array}{l}\text { Confirma a hipótese de que } \\
\text { as exportações promovem } \\
\text { crescimento e sugere a } \\
\text { existência de um efeito de } \\
\text { limiar (threshold effect). A } \\
\text { taxa de crescimento parece } \\
\text { não afetada pelo trabalho, } \\
\text { enquanto capital tem efeitos } \\
\text { limitados devido aos níveis } \\
\text { de produtividade. }\end{array}$ \\
\hline
\end{tabular}




\begin{tabular}{|c|c|c|}
\hline $\begin{array}{c}\text { Colombatto } \\
\text { (1990) }\end{array}$ & $\begin{array}{l}\text { Amostra - } 47 \\
\text { Período de Estudo - 1971, } 1978 \text { e } 1985 \\
\text { Série de Dados - Cross-section (corte transversal) - } 3 \text { anos } \\
\text { separados } \\
\text { Técnica Econométrica - Estimadores de Mínimos Quadrados, } \\
\text { coeficientes de correlação } \\
\text { Outras Variáveis - consumo do governo, exportação agrícola e } \\
\text { grau de abertura }\end{array}$ & $\begin{array}{l}\text { Rejeita a hipótese de que as } \\
\text { exportações promovem } \\
\text { crescimento. }\end{array}$ \\
\hline Fosu (1990) & $\begin{array}{l}\text { Amostra - } 28 \\
\text { Período de Estudo - 1960-1970 / 1970-1980 } \\
\text { Série de Dados - Cross-section (corte transversal) } 2 \text { períodos } \\
\text { (países africanos) } \\
\text { Crescimento Econômico - Crescimento do PIB } \\
\text { Exportação - Taxa de crescimento de exportação de mercadorias } \\
\text { Técnica Econométrica - Mínimos Quadrados, função produção } \\
\text { Outras Variáveis - Taxa de crescimento de investimento, aumento } \\
\text { da mão de obra (trabalho) }\end{array}$ & $\begin{array}{l}\text { Aceita (confirma) a } \\
\text { hipótese de que as } \\
\text { exportações promovem } \\
\text { crescimento. }\end{array}$ \\
\hline $\begin{array}{l}\text { Kugler } \\
(1991)\end{array}$ & $\begin{array}{l}\text { Amostra - 6 } \\
\text { Período de Estudo - 1970(1)- 1987(4) países industrializados } \\
\text { Série de Dados - Séries Temporais } \\
\text { Crescimento Econômico - PIB marginal no caso do PNB } \\
\text { americano } \\
\text { Exportação - Crescimento real das Exportações } \\
\text { Técnica Econométrica - teste de raiz unitária (ADF), VARs, } \\
\text { procedimento Johansen } \\
\text { Outras Variáveis - Consumo (bens duráveis, não duráveis e } \\
\text { serviços), investimento }\end{array}$ & $\begin{array}{l}\text { Há apenas uma evidência } \\
\text { empírica fraca que confirma } \\
\text { a hipótese do crescimento } \\
\text { conduzido por exportações. } \\
\text { Em apenas } 2 \text { casos, de } 6, \text { a } \\
\text { relação é verificada (França } \\
\text { e oeste alemão). }\end{array}$ \\
\hline $\begin{array}{c}\text { Afxentiou } \\
\text { \& Serletis } \\
(1991)\end{array}$ & $\begin{array}{l}\text { Amostra - } 16 \\
\text { Período de Estudo - 1950-1985 países industrializados } \\
\text { Série de Dados - Séries Temporais } \\
\text { Crescimento Econômico - Crescimento real do PNB } \\
\text { Exportação - Crescimento real das Exportações } \\
\text { Técnica Econométrica - raiz unitária de Phillips-Perron, } \\
\text { procedimento Engle-Granger, teste de causalidade de Granger }\end{array}$ & $\begin{array}{l}\text { Nenhuma relação } \\
\text { sistemática entre exportação } \\
\text { e PIB é verificada. Apenas } \\
\text { em } 2 \text { casos, de } 16 \text {, a } \\
\text { causalidade bidirecional é } \\
\text { verificada (EUA e } \\
\text { Noruega). }\end{array}$ \\
\hline $\begin{array}{c}\text { Sengupta } \\
(1991)\end{array}$ & $\begin{array}{l}\text { Amostra - } 5 \\
\text { Período de Estudo - 1967-1986 sudeste asiático (República da } \\
\text { Coréia) } \\
\text { Série de Dados - Séries Temporais } \\
\text { Crescimento Econômico - crescimento real do PIB } \\
\text { Exportação - Crescimento real das Exportações } \\
\text { Técnica Econométrica - Estimadores de Mínimos Quadrados, } \\
\text { função produção } \\
\text { Outras Variáveis - aumento da mão de obra e aumento de capital }\end{array}$ & $\begin{array}{l}\text { Aceita (confirma) a } \\
\text { hipótese de que as } \\
\text { exportações promovem } \\
\text { crescimento e sugere os } \\
\text { efeitos positivos da } \\
\text { externalidade das } \\
\text { exportações no crescimento. }\end{array}$ \\
\hline $\begin{array}{c}\text { Serletis } \\
(1992)\end{array}$ & $\begin{array}{l}\text { Amostra - } 1 \\
\text { Período de Estudo - 1870-1985 Canadá } \\
\text { Série de Dados - Séries Temporais } \\
\text { Crescimento Econômico - Crescimento real do PNB } \\
\text { Exportação - Crescimento real das Exportações } \\
\text { Técnica Econométrica - testes de raiz unitária (ADF), } \\
\text { procedimento Engle-Granger, teste de causalidade de Granger } \\
\text { Outras Variáveis - Importação }\end{array}$ & $\begin{array}{l}\text { Aceita (confirma) a } \\
\text { hipótese de que as } \\
\text { exportações promovem } \\
\text { crescimento no curto prazo, } \\
\text { no entanto nenhuma } \\
\text { cointegração entre as } \\
\text { variáveis foi encontrada. }\end{array}$ \\
\hline $\begin{array}{l}\text { Khan \& } \\
\text { Saqib } \\
\text { (1993) }\end{array}$ & $\begin{array}{l}\text { Amostra - 1 } \\
\text { Período de Estudo - 1972-1988 Paquistão } \\
\text { Série de Dados - Séries Temporais } \\
\text { Crescimento Econômico - Crescimento PIB } \\
\text { Exportação - Crescimento real das exportações: produtos primários } \\
\text { e produtos manufaturados } \\
\text { Técnica Econométrica - 3SLS, função produção } \\
\text { Outras Variáveis - aumento da mão de obra (trabalho), aumento do } \\
\text { capital, índice mundial do PIB, preços relativos }\end{array}$ & $\begin{array}{l}\text { Confirma (aceita) a hipótese } \\
\text { de uma forte associação } \\
\text { entre exportação e } \\
\text { crescimento. }\end{array}$ \\
\hline
\end{tabular}




\begin{tabular}{|c|c|c|}
\hline $\begin{array}{c}\text { Lussier } \\
(1993)\end{array}$ & $\begin{array}{l}\text { Amostra - } 24 \text { \& } 19 \\
\text { Período de Estudo - 1960-1990 economias africanas } \\
\text { Série de Dados - Cross-section (corte transversal) e dados em } \\
\text { painel } \\
\text { Crescimento Econômico - Crescimento do PIB } \\
\text { Exportação - Crescimento real das Exportações } \\
\text { Técnica Econométrica - Estimadores de Mínimos Quadrados, } 4 \\
\text { versões da função produção } \\
\text { Outras Variáveis - aumento da mão de obra (trabalho), } \\
\text { Investimento interno/PIB, participação da exportação no PIB }\end{array}$ & $\begin{array}{l}\text { Confirma a hipótese nos } \\
\text { dados em painel, mas falha } \\
\text { em encontrar alguma } \\
\text { associação positiva ao usar } \\
\text { crescimento das } \\
\text { exportações como } \\
\text { participação do PIB. }\end{array}$ \\
\hline $\begin{array}{l}\text { Sheehey } \\
\text { (1993) }\end{array}$ & $\begin{array}{l}\text { Amostra - } 31 \text { \& } 65 \\
\text { Período de Estudo - 1960-1970 países semi-industrializados } \\
\text { Série de Dados - Cross-section (corte transversal) } \\
\text { Crescimento Econômico - Crescimento do PIB } \\
\text { Exportação - Crescimento real das Exportações } \\
\text { Técnica Econométrica - Estimadores de Mínimos Quadrados, } \\
\text { função produção } \\
\text { Outras Variáveis - aumento da mão de obra (trabalho), } \\
\text { Investimento interno/PIB, participação da exportação no PIB }\end{array}$ & $\begin{array}{l}\text { Evidência inconsistente de } \\
\text { alta produtividade no setor } \\
\text { exportador comparada ao } \\
\text { setor não exportador; assim, } \\
\text { sugere cautela ao analisar } \\
\text { resultados empíricos. }\end{array}$ \\
\hline $\begin{array}{l}\text { Greenaway } \\
\text { \& Sapsford } \\
(1994)\end{array}$ & $\begin{array}{l}\text { Amostra - } 19 \\
\text { Período de Estudo - 1957-1985 1970-1985 1971-1985 } \\
\text { Série de Dados - Séries Temporais } \\
\text { Crescimento Econômico - Crescimento real do PIB } \\
\text { Exportação - Crescimento real das exportações e mudança nas } \\
\text { exportações/produtividade } \\
\text { Técnica Econométrica - Estimadores de Mínimos Quadrados, } 3 \\
\text { versões da função produção } \\
\text { Outras Variáveis - aumento da mão de obra (trabalho), taxa de } \\
\text { crescimento do investimento }\end{array}$ & $\begin{array}{l}\text { Pequeno apoio à hipótese de } \\
\text { crescimento conduzido pela } \\
\text { exportação e para os efeitos } \\
\text { positivos da liberalização } \\
\text { no crescimento. }\end{array}$ \\
\hline $\begin{array}{c}\text { Lee \& Cole } \\
\text { (1994) }\end{array}$ & $\begin{array}{l}\text { Amostra - } 73 \\
\text { Período de Estudo - 1960-1970 1970-1977 } \\
\text { Série de Dados - Cross section (corte transversal) - } 2 \text { sub-períodos } \\
\text { Crescimento Econômico - Crescimento real do PNB } \\
\text { Exportação - Crescimento real das Exportações } \\
\text { Técnica Econométrica - 2SLS, função produção, teste de Hausman } \\
\text { Outras Variáveis - aumento da mão de obra, Investimento } \\
\text { interno/PIB }\end{array}$ & $\begin{array}{l}\text { Confirma a existência de } \\
\text { causalidade bidirecional } \\
\text { entre exportação e } \\
\text { crescimento. }\end{array}$ \\
\hline $\begin{array}{l}\text { Van den } \\
\text { Berg \& } \\
\text { Schmidt } \\
(1994)\end{array}$ & $\begin{array}{l}\text { Amostra - } 17 \\
\text { Período de Estudo - 1960-1987 América Latina } \\
\text { Série de Dados - Séries Temporais } \\
\text { Crescimento Econômico - Crescimento real do PIB } \\
\text { Exportação - Crescimento real das Exportações } \\
\text { Técnica Econométrica - teste de raiz unitária de Phillips-Perron, } \\
\text { Procedimento Engle-Granger de dois passos, Estimadores do } \\
\text { Método de Mínimos Quadrados, VARs, função produção } \\
\text { Outras Variáveis - Investimento interno/PIB, crescimento da } \\
\text { população }\end{array}$ & $\begin{array}{l}\text { Aponta para uma positiva } \\
\text { relação de longo prazo entre } \\
\text { exportações e crescimento } \\
\text { em } 11 \text { dos } 16 \text { casos } \\
\text { analisados. Costa Rica está } \\
\text { entre os países em que a } \\
\text { hipótese foi confirmada. }\end{array}$ \\
\hline $\begin{array}{l}\text { Figueroa de } \\
\text { la Barra \& } \\
\text { Letelier- } \\
\text { Saavedra } \\
\text { (1994) }\end{array}$ & $\begin{array}{l}\text { Amostra - } 1 \\
\text { Período de Estudo - 1979(1)- 1993(4) Chile } \\
\text { Série de Dados - Séries Temporais (trimestrais) } \\
\text { Crescimento Econômico - PIB real } \\
\text { Exportação - exportação e mudança nas exportações/produtividade } \\
\text { Técnica Econométrica - teste da raiz unitária (ADF), VARs, } \\
\text { procedimento de Johansen } \\
\text { Outras Variáveis - capital, (exportações + importações)/PIB, força } \\
\text { de trabalho }\end{array}$ & $\begin{array}{l}\text { Confirma a hipótese de } \\
\text { crescimento baseado em } \\
\text { exportações. Os resultados } \\
\text { não mudam } \\
\text { independentemente dos } \\
\text { índices de orientação } \\
\text { externa usados. }\end{array}$ \\
\hline
\end{tabular}




\begin{tabular}{|c|c|c|}
\hline Jin (1995) & $\begin{array}{l}\text { Amostra - } 4 \\
\text { Período de Estudo - 1976(2)-1993(2) Tigres Asiáticos } \\
\text { Série de Dados - Séries Temporais } \\
\text { Crescimento Econômico - PIB real } \\
\text { Exportação - exportação real } \\
\text { Técnica Econométrica - Teste F, teste da raiz unitária (ADF), } \\
\text { função de resposta ao impulso, VARs, procedimento de dois passos } \\
\text { de Engle-Granger } \\
\text { Outras Variáveis - Taxa de câmbio real, choque nos preços } \\
\text { estrangeiros, choque de produtividade }\end{array}$ & $\begin{array}{l}\text { Causalidade bidirecional foi } \\
\text { encontrada no curto prazo, } \\
\text { mas nenhuma cointegração } \\
\text { foi detectada, então } \\
\text { nenhuma relação de longo } \\
\text { prazo foi provada. }\end{array}$ \\
\hline $\begin{array}{l}\text { Henriques } \\
\text { \& Sadorsky } \\
(1996)\end{array}$ & $\begin{array}{l}\text { Amostra - 1 } \\
\text { Período de Estudo - 1870-1991 Canadá } \\
\text { Série de Dados - Séries Temporais } \\
\text { Crescimento Econômico - Crescimento real do PIB } \\
\text { Exportação - Crescimento real das Exportações } \\
\text { Técnica Econométrica - teste da raiz unitária (ADF), VARs, } \\
\text { procedimento de Johansen, teste de causalidade de Granger } \\
\text { Outras Variáveis - Termos de negócio }\end{array}$ & $\begin{array}{l}\text { Não confirma a hipótese de } \\
\text { crescimento baseado em } \\
\text { exportação, mas falha ao } \\
\text { rejeitar a hipótese. }\end{array}$ \\
\hline $\begin{array}{c}\text { Al-Yousif } \\
(1997)\end{array}$ & $\begin{array}{l}\text { Amostra - } 4 \\
\text { Período de Estudo - 1973-1993 países do golfo árabe } \\
\text { Série de Dados - Séries Temporais } \\
\text { Crescimento Econômico - Crescimento real do PIB } \\
\text { Exportação - crescimento real das exportações e mudança nas } \\
\text { exportações/produtividade } \\
\text { Técnica Econométrica - teste da raiz unitária (ADF), teste branco, } \\
\text { função produção } \\
\text { Outras Variáveis - Força de trabalho e Investimento/PIB }\end{array}$ & $\begin{array}{l}\text { Comprova a hipótese no } \\
\text { curo prazo; no entanto, } \\
\text { falha ao encontrar uma } \\
\text { relação de longo prazo, quer } \\
\text { dizer, não encontra } \\
\text { cointegração. }\end{array}$ \\
\hline $\begin{array}{l}\text { Islam } \\
(1998)\end{array}$ & $\begin{array}{l}\text { Amostra - 15 } \\
\text { Período de Estudo - 1967-1991 Países recentemente } \\
\text { industrializados da Ásia } \\
\text { Série de Dados - Séries Temporais } \\
\text { Crescimento Econômico - Crescimento real do PIB } \\
\text { Exportação - Crescimento das Exportações e mudança nas } \\
\text { exportações/produtividade } \\
\text { Técnica Econométrica - teste da raiz unitária (ADF), teste de } \\
\text { causalidade de Granger, modelo de correção de erros } \\
\text { Outras Variáveis - Importação, gastos do governo, orientação para } \\
\text { o comércio, investimentos, instabilidade nos ganhos com exportação }\end{array}$ & $\begin{array}{l}\text { Comprova a hipótese em } \\
\text { curto prazo, mas apenas em } \\
5 \text { casos a relação de longo } \\
\text { prazo (sem cointegração) } \\
\text { foi encontrada. }\end{array}$ \\
\hline $\begin{array}{c}\text { Shan \& Sun } \\
\text { (1998) }\end{array}$ & $\begin{array}{l}\text { Amostra - 1 } \\
\text { Período de Estudo - 1978(5)- 1996(5) China } \\
\text { Série de Dados - Séries Temporais (mensal) } \\
\text { Crescimento Econômico - Produtividade industrial real } \\
\text { Exportação - Crescimento das Exportações } \\
\text { Técnica Econométrica - função produção, VAR } \\
\text { Outras Variáveis - força de trabalho, investimento e consumo de } \\
\text { energia }\end{array}$ & $\begin{array}{l}\text { Indica causalidade } \\
\text { bidirecional entre } \\
\text { exportação e produtividade } \\
\text { real. Rejeita a hipótese de } \\
\text { crescimento baseado em } \\
\text { exportações. }\end{array}$ \\
\hline $\begin{array}{c}\text { Begum \& } \\
\text { Shamsuddin } \\
\text { (1998) }\end{array}$ & $\begin{array}{l}\text { Amostra - } 1 \\
\text { Período de Estudo - 1961-1992 Bangladesh } \\
\text { Série de Dados - Séries Temporais } \\
\text { Crescimento Econômico - PIB real } \\
\text { Exportação - Crescimento das Exportações e mudança nas } \\
\text { exportações/produtividade } \\
\text { Técnica Econométrica - Estimadores de Mínimos Quadrados, } \\
\text { VAR, função produção, estimador de probabilidade máxima (MLE) } \\
\text { e o modelo ARCH } \\
\text { Outras Variáveis - força de trabalho, Investimento interno/PIB }\end{array}$ & $\begin{array}{l}\text { Confirma (aceita) a hipótese } \\
\text { de que o crescimento é } \\
\text { conduzido pela exportação. }\end{array}$ \\
\hline
\end{tabular}

Quadro 4.3 - Crescimento Econômico e Exportações (MEDINA-SMITH, 2001) 
Com base nos estudos de Jayme Jr. (2001), Matos (2002, 2003) e Medina-Smith (2001) é possível verificar que não há resultado conclusivo sobre os efeitos da exportação sobre o crescimento. Esse levantamento ainda colabora para o melhor desenvolvimento da revisão bibliográfica, assim como para ilustrar os indicadores que foram utilizados em trabalhos anteriores para verificar a hipótese de causalidade entre comércio internacional, através das exportações e crescimento econômico.

\subsection{INDICADORES SUGERIDOS PELA REVISÃO BIBLIOGRÁFICA}

Este estudo busca analisar se há evidência de causalidade entre fluxos de capitais externos, crescimento e desenvolvimento econômico. Assim, para efeito de análise, os indicadores devem ser divididos em grupos representando os fluxos externos (bens e capitais), crescimento e desenvolvimento econômico.

Conforme já apresentado e discutido no por Medina-Smith (2001), Gremaud, Vasconcellos e

Toneto Jr. (2002), Gremaud et al (2003) e Cordeiro (2005), as medidas mais comuns para se avaliar o crescimento econômico são o Produto Interno Bruto (PIB) e Produto Nacional Bruto (PNB).

Alguns autores também consideram o aumento da produtividade industrial como medida de crescimento. A produtividade é determinada por diversos fatores. Para Mankiw (2005) a produtividade é determinada pelo capital físico, capital humano e conhecimento tecnológico. Para Smith (1996) o crescimento da produtividade do trabalho permite o crescimento do estoque de capital, promovendo o crescimento. Prebisch (1963) e Marx (1996) também 
consideram que o aumento da produtividade promovida pela evolução tecnológica aumentaria o acúmulo de capital e renda. Mill (1996) também faz considerações sobre a influência do progresso técnico sobre a distribuição do produto entre capitalistas. Segundo o autor, o aumento da produção pode resultar crescimento demográfico, acumulação de capital ou inovações tecnológicas na produção e comércio de bens.

Solow apresenta um modelo que atribui o crescimento econômico à acumulação de capital, ao crescimento da força de trabalho e às alterações tecnológicas (LOPES; VASCONCELLOS, 2000). Krugman e Obstfeld (2005) avaliam que a relativa escassez de capital e de trabalho especializado (capital humano) contribui para baixos níveis de renda per capita e impedem países em desenvolvimento de realizar economias de escala.

De acordo com Almeida (1991), Rocha e Ferreira (2001) e Mankiw (2005), o incentivo à pesquisa, a disseminação do conhecimento tecnológico e a inovação tecnológica são relacionados com os esforços em planejamento e desenvolvimento (P\&D). Empresas que investem em $\mathrm{P} \& \mathrm{D}$ tendem a desenvolver novas tecnologias que proporcionam aumento de produtividade e conseqüente competitividade. Essas empresas ainda podem ceder direitos de uso para terceiros.

Assim, os investimentos em P\&D e as receitas e despesas com royalties são indicadores que podem avaliar o desenvolvimento de tecnologia no país. Almeida (1991) ainda considera que a pesquisa local pelas corporações transnacionais pode traduzir-se em futuras remessas de royalties ao exterior se os direitos de propriedade intelectual pertencerem à empresa matriz, independentemente da localização da pesquisa. 
Sitglitz e Walsh (2003) consideram que o capital humano altamente qualificado pode ser uma grande fonte de aumento de produtividade. De acordo com Therborn (2001), o aumento da competitividade da indústria nacional é dado em função da produtividade e da difusão do conhecimento. Os indicadores para avaliar a qualificação e o capital humano são o número de anos de estudo da população em idade ativa (PIA), a taxa de analfabetismo e o percentual da população economicamente ativa com grau de instrução igual ou superior ao $2^{\circ}$ grau. Segundo Pereira (2003), a inserção de variáveis como capital humano, tecnologia e inovação na função de produção permite explicar e quantificar o crescimento através da evolução do PIB.

Outros fatores que influenciam o crescimento são a poupança e o investimento. O estoque de capital é influenciado pela taxa de poupança, de forma que um aumento na taxa de poupança eleva os investimentos e em longo prazo o estoque de capital também será elevado (LOPES; VASCONCELLOS, 2000). Segundo a Bovespa (2000), a maneira mais eficiente de associar poupança e investimento é através do mercado de capitais, pois aproxima agentes poupadores e tomadores.

Para Lopes e Vasconcellos (2000), o modelo Harrod-Domar considera que o desenvolvimento econômico é dado em função de três variáveis básicas para o crescimento: a taxa de investimento, a taxa de poupança e a relação produto-capital. Segundo os autores, o modelo Solow atribui o crescimento econômico à acumulação de capital. Stiglitz e Walsh (2003) consideram a poupança como um dos fatores que determinam a produtividade.

A taxa de poupança da economia determina a quantidade de seu estoque de capital e, portanto, seu nível de produção. Marshall (1996) também considera que uma restrição moderada e 
temporária à acumulação de riqueza proporciona melhores oportunidades à população, aumentando sua eficiência e proporcionando crescimento.

Stiglitz e Walsh (2003, p. 191) consideram que maiores níveis de investimento em relação ao PIB resultam em mais capital por trabalhador. Harrod-Domar, em seu modelo, consideram que a taxa de investimento é um dos fatores que influencia o crescimento e desenvolvimento (LOPES; VASCONCELLOS, 2000).

Gremaud et al (2003) consideram que para avaliar desenvolvimento deve-se medir a diminuição do nível de pobreza. Assim, não se deve apenas considerar a evolução do PIB como medida de aumento de riqueza, sem considerar o tamanho da população. Para se quantificar o grau de desenvolvimento do país, verifica-se que uma primeira medida é a utilização do conceito de produto per capita (GREMAUD; VASCONCELLOS; TONETO JR., 2002).

De acordo com Gremaud et al (2003), o produto nacional per capita tem sido o critério convencional de desenvolvimento e subdesenvolvimento econômico. Fritsch (1996) reforça essa idéia ao considerar que a riqueza ou o bem-estar das nações é identificado com seu produto anual per capita. Outro critério também utilizado para medir desenvolvimento é o produto interno bruto per capita (GREMAUD; VASCONCELLOS; TONETO JR., 2002).

Segundo Gremaud et al (2003), o critério de produto per capita pode ser aplicado ao nível ou à taxa de renda per capita. Souza (2005) avalia que o crescimento da renda per capita é fundamental para melhorar indicadores sociais. Veiga (2005) corrobora a utilização de renda 
per capita como índice para sintetizar desenvolvimento em razão de sua simplicidade e comodidade. Gremaud et al (2003) complementa que:

[...] o aspecto fundamental é que desenvolvimento não pode ser analisado somente por meio de indicadores que medem o crescimento do produto ou do produto per capita. Desenvolvimento deve ser complementado por índices que representem, ainda que de forma incompleta, a qualidade de vida dos indivíduos, tais como renda per capita, expectativa de vida, mortalidade infantil, fertilidade, educação, analfabetismo, distribuição de renda entre diferentes classes e setores, centralização da atividade econômica, poder político, entre outras.

Com relação à renda, Hoffmann (1998a, p. 209) avalia que "se o objetivo do estudo for analisar o nível de vida ou bem-estar das pessoas, a variável mais apropriada não é o rendimento por pessoa economicamente ativa, pois o nível de vida é, em geral, determinado pela renda familiar e não necessariamente pelo rendimento individual”. O autor considera ainda que a melhor alternativa para analisar as diferenças de nível de vida ou pobreza relativa é o rendimento domiciliar per capita.

Souza (2005) avalia que outros indicadores (alimentação, atendimento médico, educação, segurança e qualidade do meio ambiente) devem ser considerados para refletir melhorias sociais e econômicas.

Com relação à questão distribuição de renda e desigualdade, abordada por Chesnais (1998), Hoffmann (1998a e 1998b) e Ricupero (2001a), Souza (2005) e Hoffmann (1998b) consideram que dois importantes indicadores utilizados para medir a desigualdade são os índices de Gini e de Theil.

Outro índice sugerido para avaliar desenvolvimento econômico e social é o Índice de Desenvolvimento Humano (IDH). Segundo Souza (2005), o IDH é sugerido para substituir os outros índices de desenvolvimento. Veiga (2005) aponta o IDH como índice que "ilustra com 
clareza diferença entre rendimento e bem-estar”. Esse índice, no entanto, deve ser analisado com reserva pela diferença de metodologia no cálculo durante os anos. Além disso, esse índice pode ter caráter ilusório pois avalia o desempenho nacional médio em termos de desenvolvimento.

[...] as médias podem ocultar as grandes disparidades existentes nos países. As desigualdades que têm por base o rendimento, a riqueza, o gênero, a raça e outras formas de desvantagens herdadas, bem como a localização, podem tornar as médias nacionais um indicador de bem-estar humano ilusório. (PNUD, 2006, p.270)

Lacerda (2004a) considera que os investimentos externos podem representar uma importante fonte alternativa de financiamento do desenvolvimento. De acordo com o levantamento de Medina-Smith (2001), para medir o investimento estrangeiro direto são sugeridas a utilização do montante do investimento estrangeiro direcionado ao Brasil e a relação entre o investimento estrangeiro direto e o PIB. Govindarajan e Gupta (1998) avaliam que os fluxos de entrada e saída de investimentos estrangeiros diretos e indiretos também podem ser utilizados.

Quanto à avaliação do comércio internacional e exportação, o levantamento feito por Medina Smith (2001) mostra que os melhores indicadores são o valor das exportações, o crescimento da exportações, a participação da exportação no PIB (coeficiente de exportação) e as exportações líquidas (saldo da balança comercial).

Para avaliar a integração do país no processo de abertura comercial são indicados o coeficiente de abertura (soma das exportações e importações em relação ao PIB, avaliando a intensidade de comércio) e a taxa de crescimento das importações e exportações (PEDROSO, 2000). Govindarajan e Gupta (1998), corroboram que o volume de exportações e importações em relação ao PIB podem ser utilizados para avaliar a integração global da economia de um 
país. Com relação ao comércio internacional e competitividade, Araújo Jr. (1996), considera um equívoco a utilização do superávit comercial como indicador de competitividade internacional. Contudo, esse indicador pode sinalizar, juntamente com o coeficiente de abertura, o padrão de comércio internacional.

Portanto, os indicadores sugeridos de crescimento econômico na revisão bibliográfica para crescimento econômico são o Produto Interno Bruto e o Produto Nacional Bruto; o capital físico (Capital de formação bruta); o capital humano (anos de estudo da população economicamente ativa e a taxa de analfabetismo), o progresso tecnológico (fluxo de royalties associados à transferência de tecnologia), a produtividade da indústria; a poupança, o investimento interno e o mercado de capitais.

Para medir desenvolvimento econômico, os índices sugeridos são renda per capita; PIB per capita; rendimento domiciliar per capita, distribuição de renda (concentração de renda dos $1 \%$ mais ricos e 50\% mais pobres), índice de Gini, índice de Theil e índice de desenvolvimento humano.

Com relação aos fluxos de capitais internacionais, os indicadores sugeridos para investimento estrangeiro são o Investimento Estrangeiro Direto e a relação entre Investimento Estrangeiro Direto e o PIB. Para análise dos fluxos de bens internacionais, os indicadores sugeridos são o volume de exportações, o coeficiente de exportação e o crescimento das exportações.

A seguir, no quadro 4.4, os indicadores são apresentados em cada grupo de estudo (crescimento, desenvolvimento e fluxos de bens e capitais externos), considerando os respectivos trabalhos em que foram sugeridos. 


\begin{tabular}{|c|c|c|}
\hline Grupo Temático & Indicador & Autores \\
\hline \multirow{7}{*}{ Crescimento Econômico } & PIB e PNB & $\begin{array}{l}\text { Cordeiro (2005); Gremaud et al (2003), } \\
\text { Medina-Smith (2001); Gremaud, } \\
\text { Vasconcellos e Toneto Jr. (2002) }\end{array}$ \\
\hline & Produtividade na Indústria & $\begin{array}{l}\text { Fritsch (1996); Krugman; Obstfeld (2005); } \\
\text { Ricardo (1996); Therborn (2001); Munhoz } \\
\text { (2004); Stiglitz e Walsh (2003); Mankiw } \\
\text { (2005); Smith (1996); Marx (1996); } \\
\text { Prebisch (1963) }\end{array}$ \\
\hline & $\begin{array}{l}\text { Capital humano (anos de } \\
\text { estudo PIA e analfabetismo) }\end{array}$ & $\begin{array}{l}\text { Krugman; Obstfeld (2005); Stiglitz e Walsh } \\
\text { (2003); Mankiw (2005); Pereira (2003); } \\
\text { Therborn (2001) }\end{array}$ \\
\hline & $\begin{array}{l}\text { Progresso Tecnológico } \\
\text { (royalties) }\end{array}$ & $\begin{array}{l}\text { Mill (1996); Mankiw (2005); Modelo } \\
\text { Solow (LOPES; VASCONCELLOS, 2000) }\end{array}$ \\
\hline & $\begin{array}{l}\text { Capital físico } \\
\text { (capital de formação bruta) }\end{array}$ & $\begin{array}{l}\text { Krugman; Obstfeld (2005); Mankiw (2005); } \\
\text { Stiglitz e Walsh (2003); Smith (1996); } \\
\text { Modelo Solow (LOPES; VASCONCELLOS, } \\
\text { 2000) }\end{array}$ \\
\hline & $\begin{array}{l}\text { Investimentos e } \\
\text { Investimentos/PIB }\end{array}$ & $\begin{array}{l}\text { Lopes; Vasconcellos (2000); Stiglitz e } \\
\text { Walsh (2003); Modelo Harrod-Domar; } \\
\text { Mankiw (2005); Medina-Smith (2001) }\end{array}$ \\
\hline & Poupança e Poupança/PIB & $\begin{array}{l}\text { Marshall, (1996); Modelo Harrod-Domar; } \\
\text { Modelo Solow; Lopes; Vasconcellos (2000); } \\
\text { Stiglitz e Walsh (2003); Mankiw (2005) }\end{array}$ \\
\hline \multirow{5}{*}{ Desenvolvimento Econômico } & Produto (PIB) per capita & $\begin{array}{l}\text { Fritsch (1996); Gremaud et al (2003); } \\
\text { Gremaud, Vasconcellos e Toneto Jr. (2002) }\end{array}$ \\
\hline & Renda per capita & $\begin{array}{l}\text { Gremaud et al (2003): Souza (2005); Veiga } \\
(2005)\end{array}$ \\
\hline & $\begin{array}{l}\text { Rendimento Domiciliar per } \\
\text { capita }\end{array}$ & Hoffmann (1998a) \\
\hline & $\begin{array}{l}\text { Índice de Gini e Theil } \\
\text { (Distribuição de Renda) }\end{array}$ & $\begin{array}{l}\text { Hoffmann (1998b); Souza (2005); Veiga } \\
\text { (2005); Chesnais (1998); Ricupero (2001a) }\end{array}$ \\
\hline & $\begin{array}{l}\text { Î́ndice de Desenvolvimento } \\
\text { Humano (IDH) }\end{array}$ & $\begin{array}{l}\text { Souza (2005); Veiga (2005); Hoffmann } \\
\text { (1998b) }\end{array}$ \\
\hline \multirow[t]{2}{*}{ Investimento Estrangeiro } & $\begin{array}{l}\text { Investimentos Estrangeiros } \\
\text { Diretos (IED) }\end{array}$ & $\begin{array}{l}\text { Lacerda (2004a); Govindarajan e Gupta } \\
\text { (1998); Medina-Smith (2001) }\end{array}$ \\
\hline & IED / PIB & Medina-Smith (2001) \\
\hline \multirow[t]{4}{*}{ Exportações } & $\begin{array}{l}\text { Comércio internacional } \\
\text { (exportações e importações) }\end{array}$ & $\begin{array}{l}\text { Gremaud et al (2003); Jayme Jr. (2001); } \\
\text { Pareto (1996); Maia (2004); Marshall } \\
\text { (1996); Medina-Smith (2001) }\end{array}$ \\
\hline & Coeficiente de Exportação & $\begin{array}{l}\text { Medina-Smith (2001); Govindarajan e Gupta } \\
\text { (1998) }\end{array}$ \\
\hline & Coeficiente de Abertura & Pedroso (2000) \\
\hline & Crescimento das exportações & Medina-Smith (2001) \\
\hline
\end{tabular}

Quadro 4.4 - Relação dos indicadores sugeridos na revisão bibliográfica 


\subsection{ANÁLISE DOS INDICADORES BRASILEIROS}

Os indicadores para este estudo são divididos em grupos, abordando crescimento, desenvolvimento econômico e fluxos internacionais de bens e capitais. A seguir são apresentados os indicadores em forma gráfica.

\subsubsection{CRESCIMENTO ECONÔMICO}

Conforme já discutido, o crescimento econômico é medido pelo PIB. Para efeito de análise, são plotados os gráficos da evolução do PIB (em valores correntes) em reais, em dólares e também com o ano base de 2005. O gráfico 4.1 apresenta a evolução do PIB em valores correntes e em dólar.

O PIB brasileiro, em valores correntes, tem crescido desde 1990. Quando indexado ao dólar, percebe-se que o indicador apresenta variações ao longo da série devido à variação cambial. Em 1999, com a desvalorização do real, o valor do PIB em dólar apresenta uma redução de $31,90 \%$ em relação ao ano anterior.

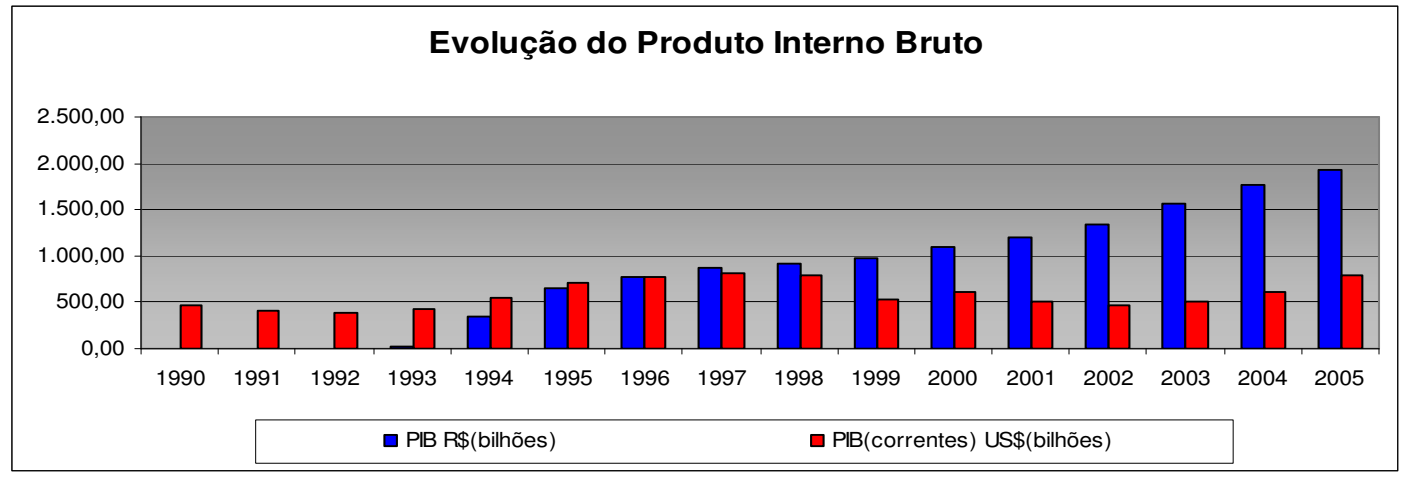

Gráfico 4.1 - Evolução do Produto Interno Bruto (R X US\$) 
Na base de 2005, o PIB apresenta crescimento anual médio de 2,08\% no período de 1990 a 2005. Contudo, ao segmentar os dados, percebe-se que de 1990 a 1994 o crescimento anual médio foi de 1,38\%. De 1994 a 1999 houve a adoção do câmbio fixo e com isso o real foi valorizado, afetando a balança comercial. Dessa forma, nesse período o crescimento caiu para 2,21\%. A partir de 1999 o crescimento médio anual voltou a subir atingindo 2,56\%. O gráfico 4.2 apresenta os dados da evolução do PIB na base de 2005 e o crescimento anual médio no período.

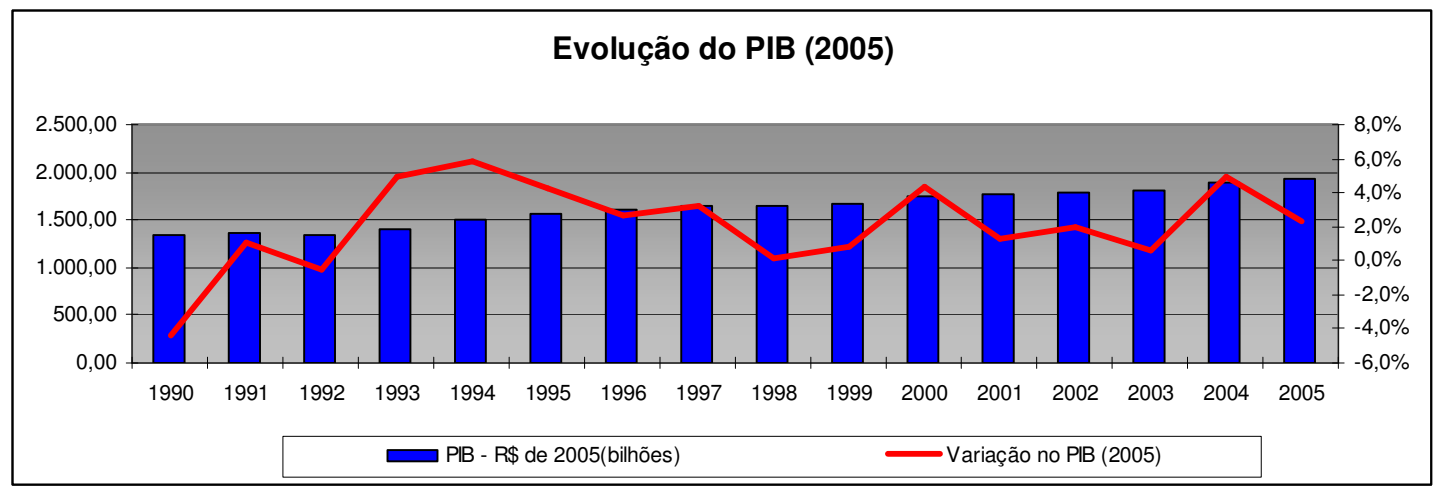

Gráfico 4.2 - Evolução do Produto Interno Bruto e variação do PIB (2005)

Com um crescimento anual médio de $2,08 \%$ no período analisado, o crescimento econômico brasileiro fica abaixo do crescimento mundial, na ordem de 3,53\% ao ano. Com base nos dados do gráfico 4.3, observa-se que apenas nos anos de 1993, 1994 e 1995 o Brasil apresentou crescimento econômico superior à média mundial.

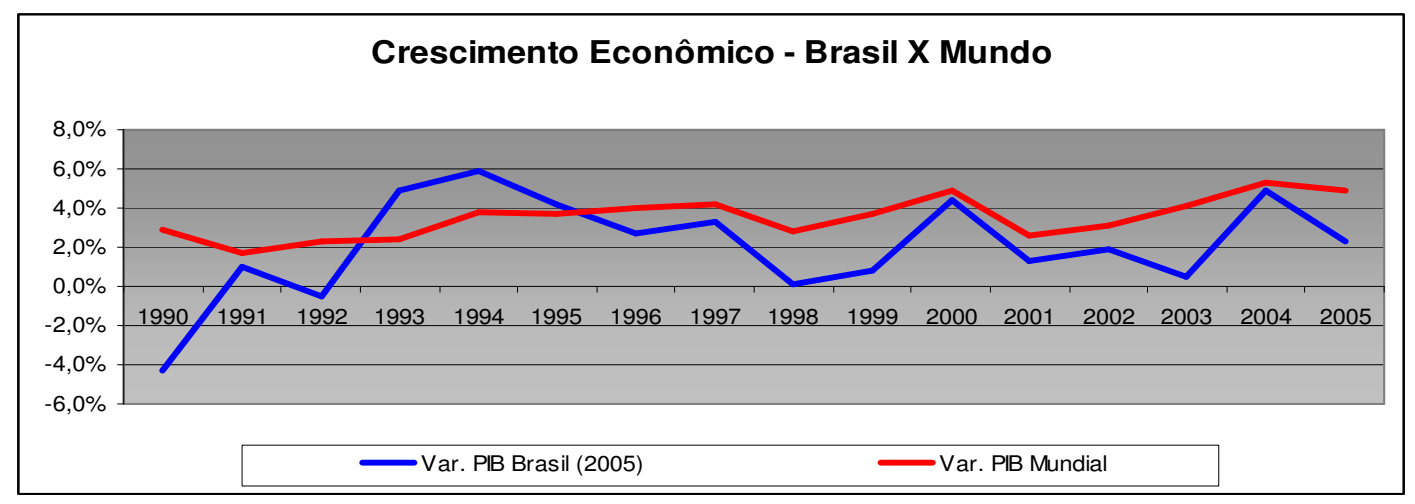

Gráfico 4.3 - Comparativo de Crescimento Econômico do Brasil e do Mundo 
Outro indicador para se avaliar o crescimento econômico é a renda nacional bruta (ou Produto Nacional Bruto - PNB). Observando o gráfico 4.4, pode-se notar que quase não há diferença entre as duas medidas. Uma vez que o indicador de crescimento econômico mais utilizado é o PIB e os dados do PNB são similares, o indicador renda nacional bruta não será utilizado nessa análise.

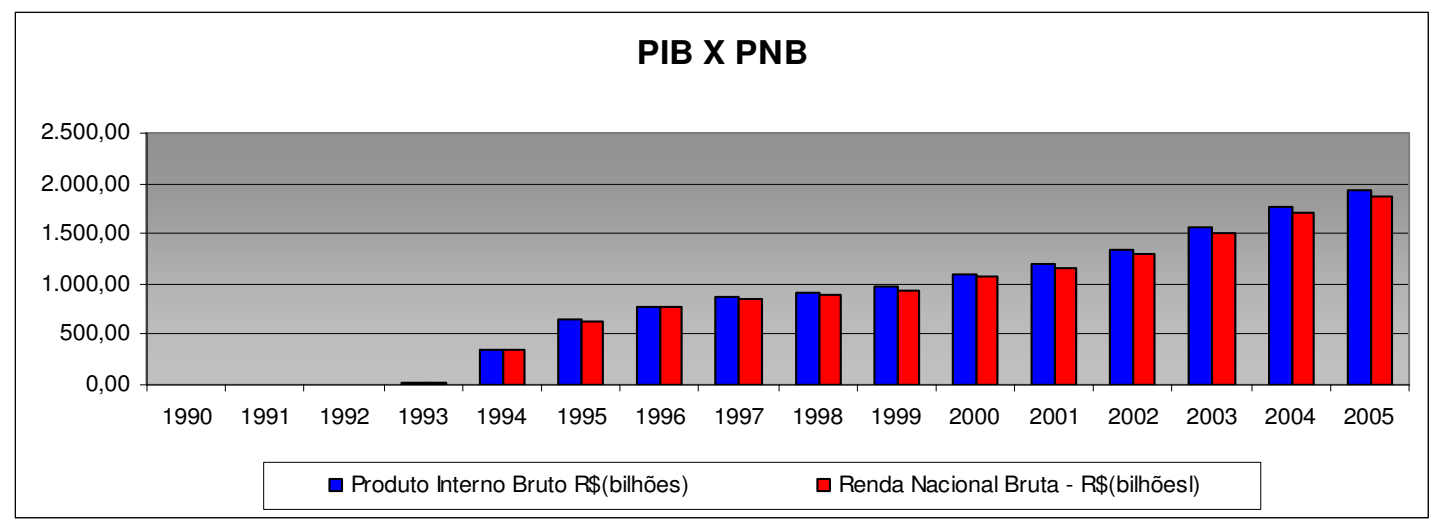

Gráfico 4.4 - Evolução do Produto Interno Bruto e Produto Nacional Bruto

Conforme discutido anteriormente, o aumento de produtividade pode promover o crescimento econômico. A produtividade, entre outros fatores, é determinada pelo capital físico, capital humano e conhecimento tecnológico. Um dos indicadores de produtividade é calculado pela razão dos índices da produção industrial e a população ocupada na indústria de transformação, considerando o ano de 1992 como ano base (1992=100).

O gráfico 4.5 apresenta a evolução da produtividade. É possível observar o aumento da produtividade, ou seja, do aumento do índice de produção em relação à população ocupada na indústria de transformação. Esse aumento pode ser devido ao investimento em capital físico, capital humano e conhecimento tecnológico, ou uma combinação de fatores. 


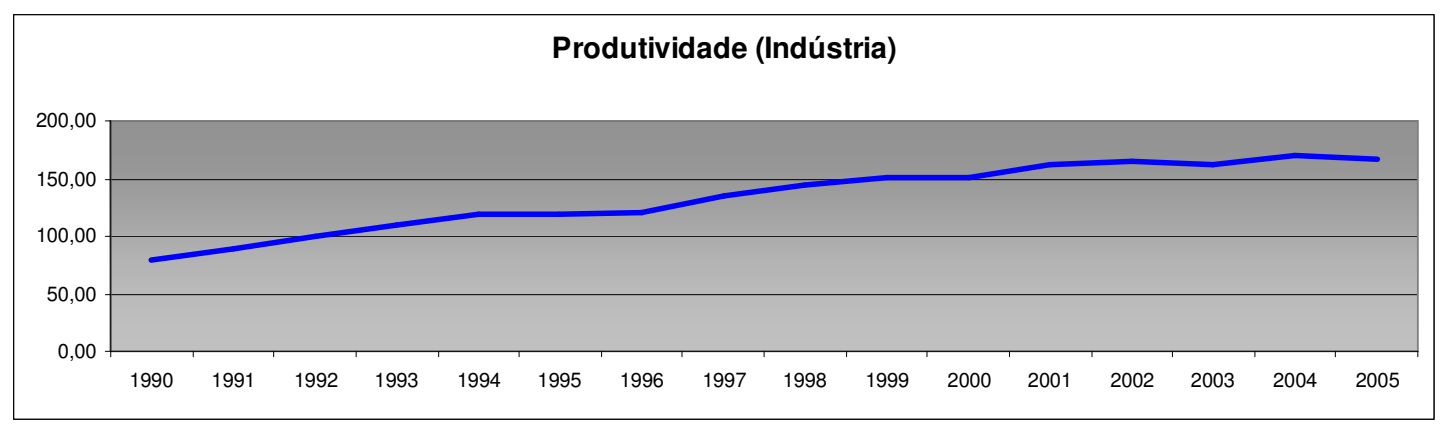

Gráfico 4.5 - Produtividade da Indústria de Transformação (1992=100)

Segundo Mankiw (2005), investimento (capital - formação bruta) consiste na compra de bens que serão utilizados no futuro para produzir bens e serviços. Essa categoria divide-se em duas subcategorias: capital fixo e variação de estoques. Pode-se observar um aumento do investimento interno no Brasil em bens e equipamentos para uso futuro.

Esse indicador também pode ser analisado em relação ao PIB. Segundo os dados observados, a participação dos investimentos no PIB oscilou entre 18,93\% (1992) e 22,29\% (1995), sendo que a média no período foi de $20,75 \%$. O gráfico 4.6 apresenta a evolução do investimento interno, em bilhões de reais e sua participação no PIB.

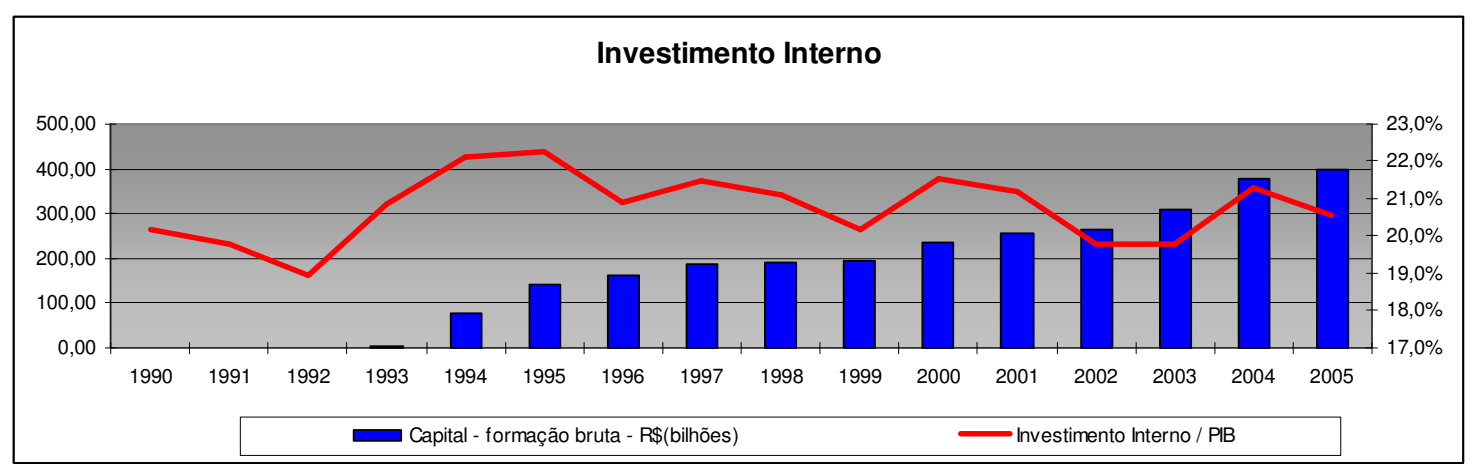

Gráfico 4.6 - Evolução do Investimento Interno e sua participação no PIB

Para medir capital humano são selecionados dois indicadores. Os anos de estudo da população em idade ativa e a taxa de analfabetismo. O primeiro indicador aponta uma melhora entre 
1990 (4,5 anos de estudo) e 2005 (6,6 anos de estudo). De acordo com esses dados, o número de anos de estudo da população em idade ativa aumentou $45,96 \%$ refletindo em uma maior capacitação dessa população. O outro indicador refere-se à taxa de analfabetismo. Por esse indicador é possível observar a redução do número de analfabetos em relação à população total em 2005 para quase metade do observado em 1990. Isso pode indicar também uma maior capacitação da mão de obra disponível para a indústria. O gráfico 4.7 apresenta a evolução desses indicadores.

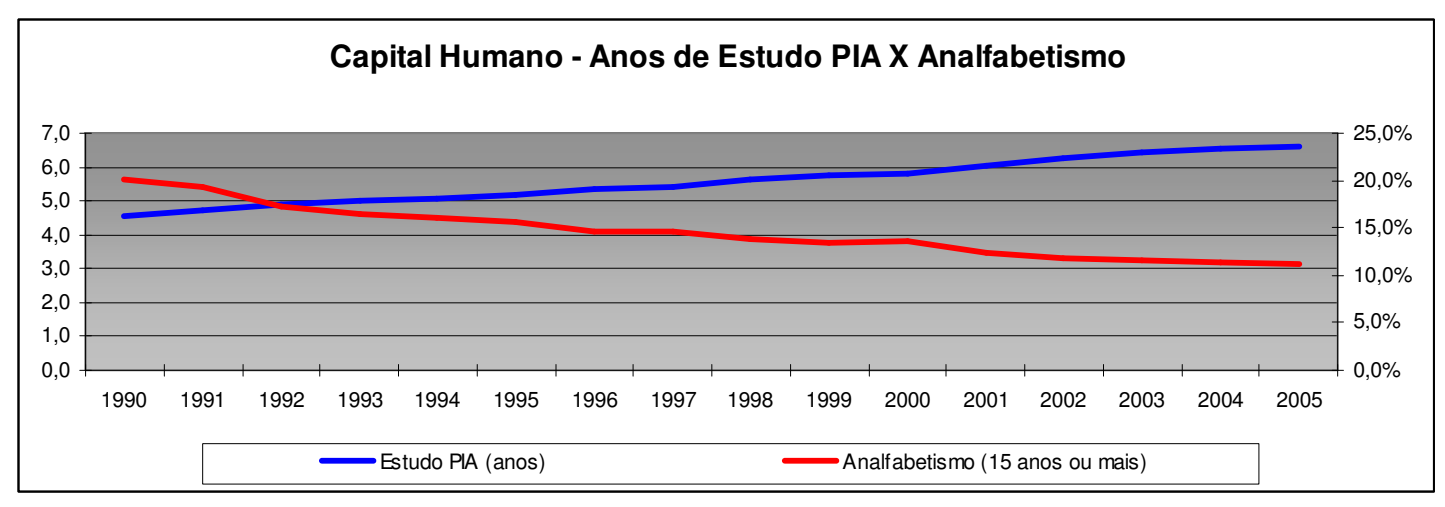

Gráfico 4.7 - Anos de estudo da população em idade ativa e taxa de analfabetismo

Com relação à inovação tecnológica, o indicador utilizado para mensurar a evolução do progresso tecnológico é o saldo com royalties e licenças (receitas e despesas com royalties e licenças). Despesas com royalties significam que as empresas instaladas no Brasil pagam para utilizar determinadas tecnologias. Receitas com royalties significam que empresas nacionais produzem tecnologia e recebem direitos pelo uso dessa tecnologia por terceiros. Assim, a diferença entre receitas e despesas com royalties e licenças indicam o progresso tecnológico em pesquisa e desenvolvimento. O gráfico 4.8 apresenta a evolução das entradas e saídas de royalties. 


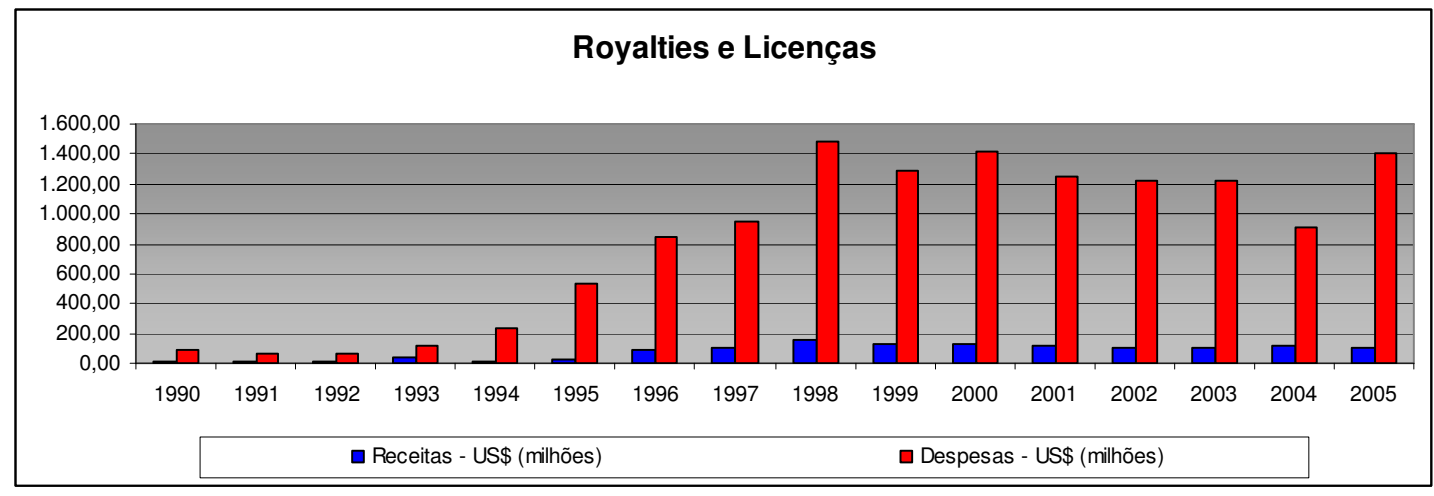

Gráfico 4.8 - Evolução das receitas e despesas com Royalties e Licenças

Outro indicador importante, discutido na revisão bibliográfica, é a poupança. A taxa de poupança na economia determina o estoque de capital e, conseqüentemente, seu nível de produção. Um dos indicadores da taxa de poupança é a relação entre poupança e PIB. É conhecido que, se comparado com alguns países asiáticos, o Brasil tem baixa taxa de poupança e isso pode ser um limitador no crescimento econômico. No período, a taxa média de poupança (em relação ao PIB) foi de $19,01 \%$ ao ano. De acordo com o gráfico 4.9 pode-se observar a evolução da poupança nacional bruta e a taxa de poupança.

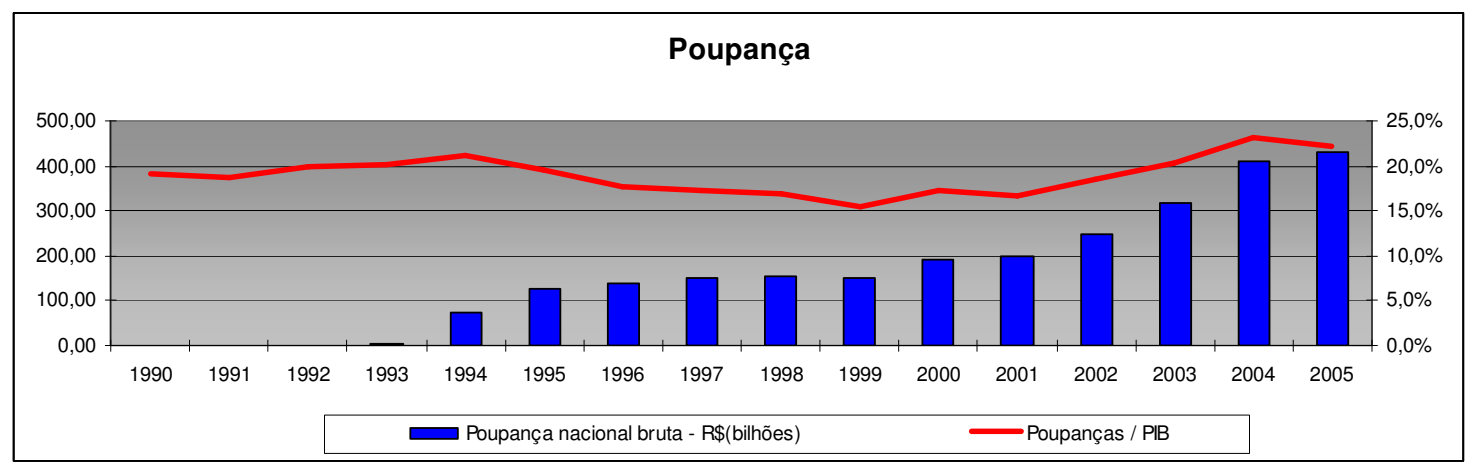

Gráfico 4.9 - Crescimento da poupança e sua variação em relação ao PIB

De acordo com Bovespa (2000) o mercado de capitais é o meio mais eficiente de associar poupança à investimento e aproximar poupadores e tomadores. Assim, a evolução do volume de negócios na Bolsa de Valores de São Paulo (BOVESPA) também pode ser um indicador 
de poupança atrelada ao investimento. Contudo, esse indicador não entra na análise, pois poupança e investimento já estão relacionados, independentemente, para a análise de causalidade. No gráfico 4.10 é possível observar a evolução do volume de negócios na Bolsa de Valores de São Paulo.

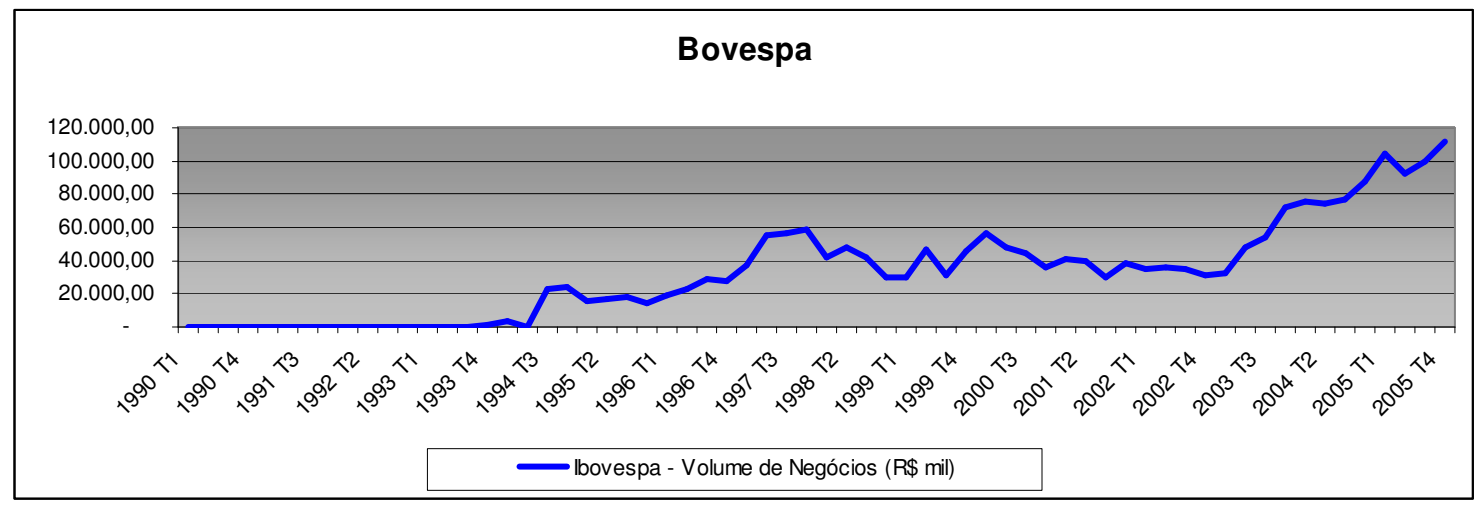

Gráfico 4.10 - Evolução do volume de negócios na Bovespa (em mil R\$)

\subsubsection{DESENVOLVIMENTO ECONÔMICO}

Segundo Gremaud, Vasconcellos e Toneto Jr. (2002), a primeira medida para quantificar o grau de desenvolvimento do país é o produto nacional per capita (ou renda per capita). Outro indicador também usado é o PIB per capita. O PIB per capita é a relação entre o Produto Interno Bruto e o tamanho da população.

Duas considerações são importantes ao avaliar esse indicador. A primeira refere-se à taxa de crescimento do PIB e a taxa de crescimento populacional. Caso a taxa de crescimento do PIB seja superior à taxa de crescimento populacional, então o indicador aumenta. Assim, crescimento populacional influencia esse indicador. A segunda consideração é sobre a questão 
da distribuição de renda. Esse indicador avalia o produto total em relação à população total, sem considerar a dispersão em relação à média.

De acordo com o gráfico 4.11, pode-se observar que o PIB per capita (em valores correntes) tem crescido no período analisado, em especial a partir de 1993. Esse indicador, contudo, devido à mudança monetária, precisa ser ajustado. Dessa forma, para maior precisão, o PIB per capita é analisado na base de 2005. De acordo com essa série histórica, tem-se que o crescimento anual médio desse indicador foi de $0,53 \%$ no período.

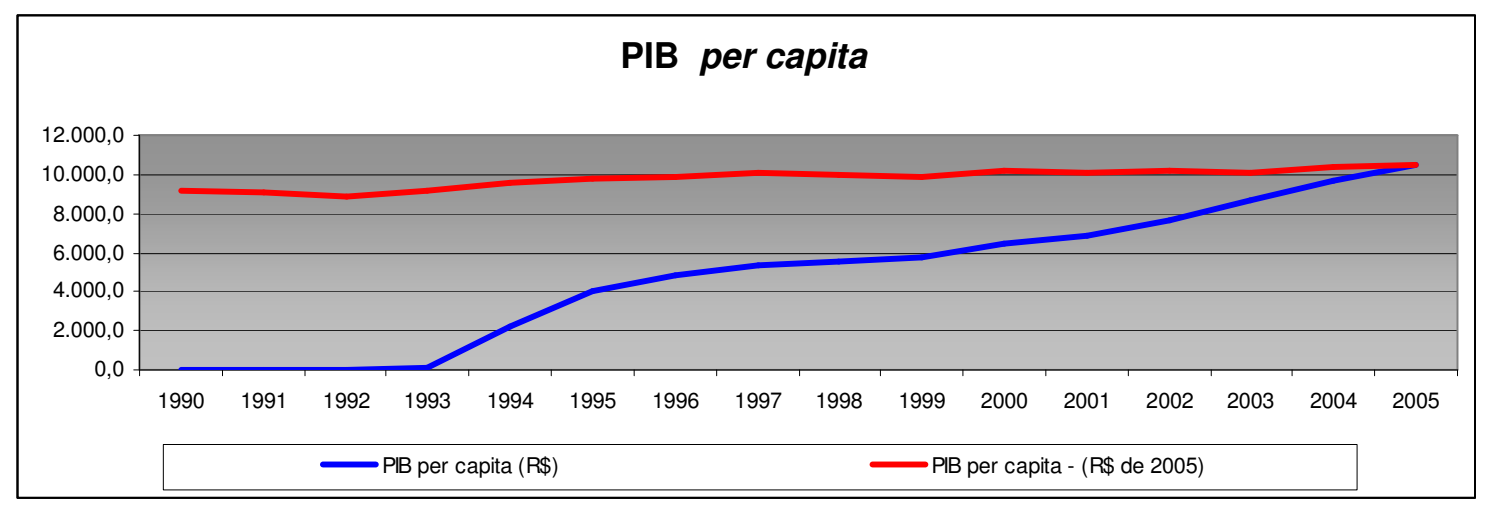

Gráfico 4.11 - Evolução do PIB per capita

Segundo Hoffmann (1998a), o nível de vida e o bem-estar das pessoas são medidos mais apropriadamente pelo rendimento domiciliar per capita. $\mathrm{O}$ rendimento domiciliar per capita no período analisado apresentou um crescimento anual médio de $0,75 \%$, oscilando nos limites de $\mathrm{R} \$ 256,39$ (valor mínimo em 1992) e $\mathrm{R} \$ 345,85$ (valor máximo em 1998).

O gráfico 4.12 apresenta a evolução do rendimento domiciliar e o PIB per capita no período analisados. 


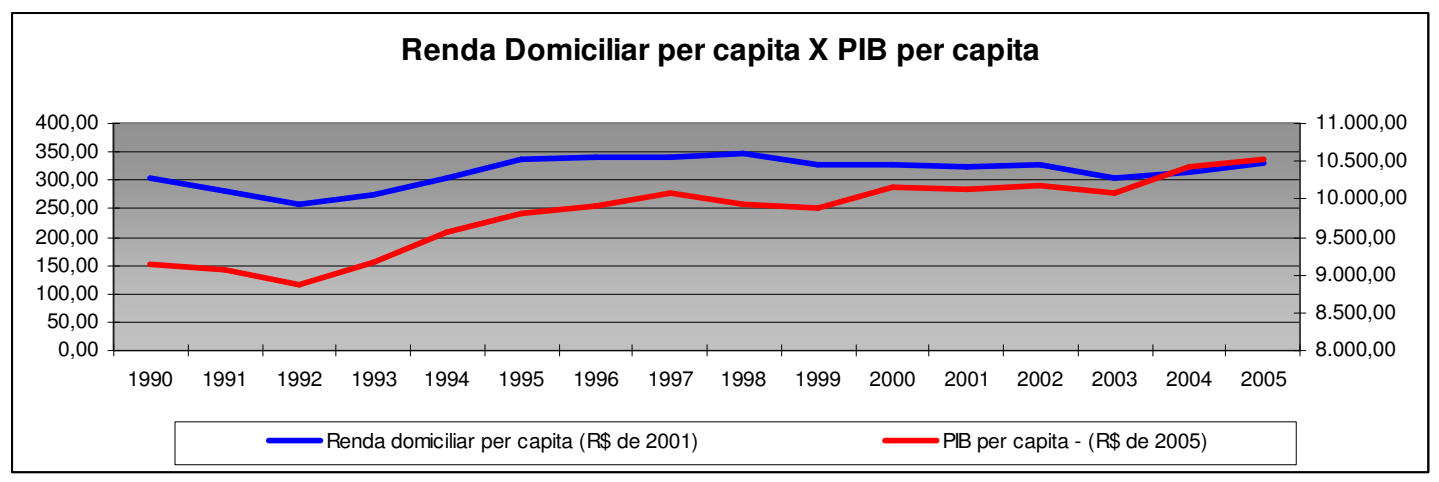

Gráfico 4.12 - Rendimento (renda domiciliar e PIB per capita)

Outro indicador importante é a concentração de renda. A renda domiciliar dos $1 \%$ mais ricos (proporção da renda apropriada pelos indivíduos pertencentes ao $1 \%$ mais rico da distribuição de indivíduos segundo a renda domiciliar per capita) apresenta tendência de queda anual média de $-0,50 \%$ enquanto a renda domiciliar dos $50 \%$ mais pobres (proporção da renda apropriada pelos indivíduos pertencentes aos 50\% mais pobres da distribuição de indivíduos segundo a renda domiciliar per capita) apresenta tendência de crescimento (média de 1,43\% ao ano). Um dado que chama a atenção é que os $1 \%$ mais ricos possuíam renda domiciliar maior do que os 50\% mais pobres de 1990 a 2002. Esse quadro foi revertido apenas em 2003. Ainda assim, a concentração de renda é muito alta, comprometendo o nível de vida e o bemestar das pessoas. O gráfico 4.13 apresenta os dados de concentração de renda no período analisado.

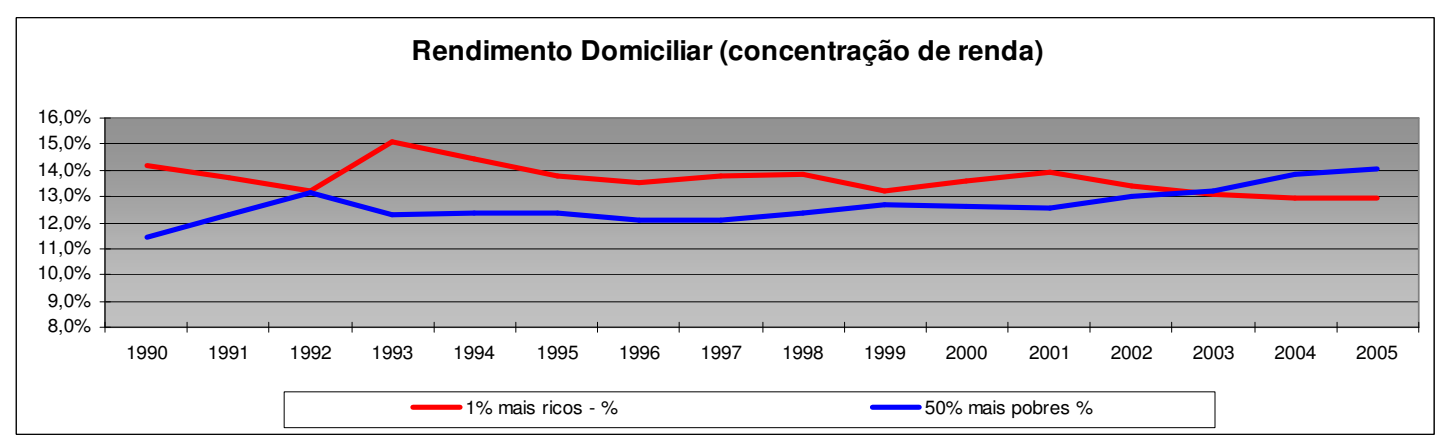

Gráfico 4.13 - Concentração de Renda (1\% mais ricos e os $50 \%$ mais pobres) 
Segundo o Instituto de Pesquisa Econômica Aplicada (IPEA), o coeficiente (ou índice) de Gini mede o grau de desigualdade existente na distribuição de indivíduos segundo a renda domiciliar per capita. Seu valor varia de 0, quando não há desigualdade (a renda de todos os indivíduos tem o mesmo valor), a 1, quando a desigualdade é máxima (apenas um indivíduo detém toda a renda da sociedade e a renda de todos os outros indivíduos é nula). O índice de Theil também mede a desigualdade na distribuição de indivíduos segundo a renda domiciliar per capita. É o logaritmo da razão entre as médias aritmética e geométrica das rendas individuais, sendo nulo quando não existir desigualdade de renda entre os indivíduos e tendente ao infinito quando a desigualdade tender ao máximo.

Ao avaliar os dados históricos, observa-se que o índice de Gini apresenta tendência de queda no período analisado. Em 1990, o índice apontava 0,6138 e caiu para 0,5692 em 2005. Essa variação aponta para uma redução na desigualdade, que contudo, ainda é alta. Ao observar o índice de Theil é possível avaliar que há uma redução da desigualdade no Brasil entre 1990 e 2005, considerando que no ano de 1993 houve uma reversão na tendência de queda. Ainda assim, o índice de Theil, para o ano de 2005, aponta 0,6588, um valor muito distante de zero (igualdade perfeita). O gráfico 4.14 apresenta a evolução dos indicadores no Brasil.

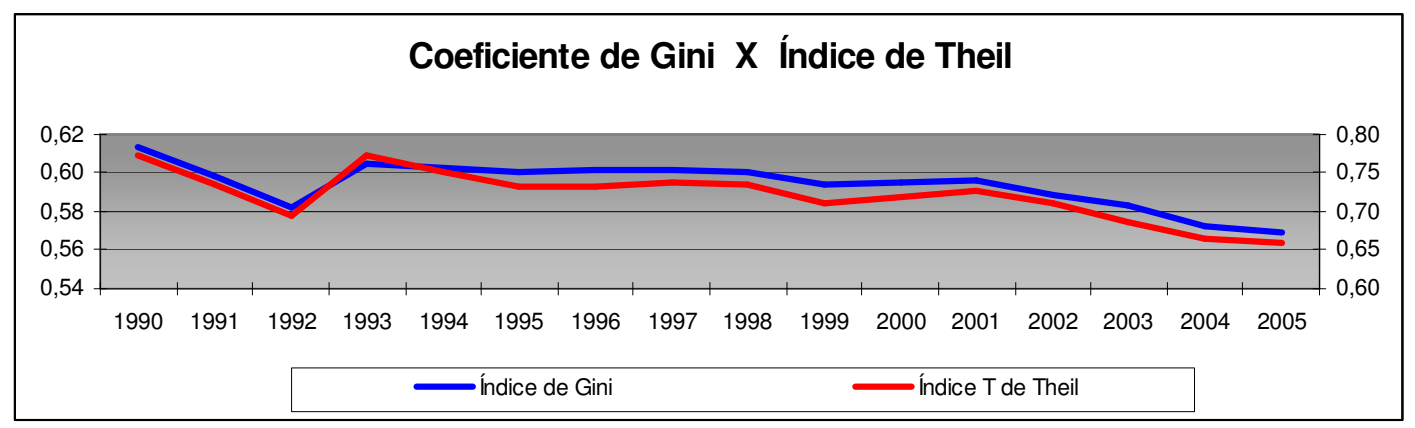

Gráfico 4.14 - Concentração de Renda - Coeficiente de Gini X Índice de Theil 
O IDH é uma medida de desenvolvimento e é sugerida por Souza (2005) para substituir outros indicadores de desenvolvimento, e por Veiga (2005), por ilustrar diferenças entre rendimento e bem-estar. Esse indicador avalia renda, longevidade e educação. Segundo o gráfico 4.15 é possível observar a evolução do indicador no Brasil.

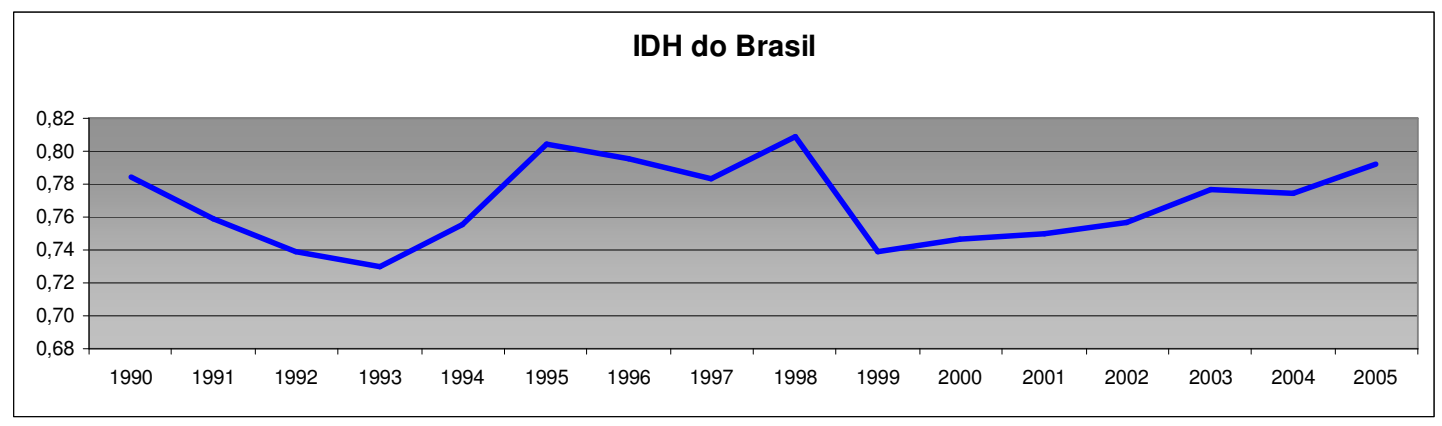

Gráfico 4.15 - Evolução do Índice de Desenvolvimento Humano no Brasil

Um importante dado é que o indicador teve a metodologia alterada em $1994^{8}$ e $1999^{9}$, e por isso deve ser analisado com cautela. O IDH é composto por três indicadores: longevidade, educação e renda. $\mathrm{O}$ indicador de longevidade apresentou evolução no período analisado. $\mathrm{O}$ indicador educação também apresentou melhora, porém o indicador renda apresentou queda em 1999, recuperando-se gradualmente até 2005, conforme apresenta o gráfico 4.16.

\footnotetext{
${ }^{8} \mathrm{O}$ indicador de escolaridade média no Brasil, no Relatório de Desenvolvimento Humano (RDH) de 1994, era de quatro anos, sendo sete o limite máximo dessa escala, sua contribuição no índice de educação correspondia, portanto, a apenas $57 \%$ no valor total deste indicador. Por outro lado, no relatório de 1995, a contribuição referente à taxa combinada de matrícula bruta no Brasil foi de $70 \%$, que é bem superior à da escolaridade média do Brasil. Desse modo, a situação relativa do Brasil, em termos de educação, foi beneficiada com a mudança de metodologia. (OLIVEIRA, 2006, pp. 34)

${ }^{9}$ A fórmula do IDH-Renda mantém-se a mesma desde o primeiro relatório do PNUD, embora a função f tenha sido alterada no relatório de 1999 e o valor-limite inferior, que era de US\$200 ppc. no relatório de 1994, passou a US\$100 ppc (PNUD, 2003). O IDH do relatório de 1999 apresentou uma acentuada queda na qualidade de vida da população do Brasil, provocada, exclusivamente, pela modificação do critério metodológico da renda. A nova metodologia de cálculo do PIB per capita considerava que para países com nível de renda per capita próximos ao brasileiro, a renda seria menos relevante do era no método anterior. (OLIVEIRA, 2006, pp. 36-37)
} 


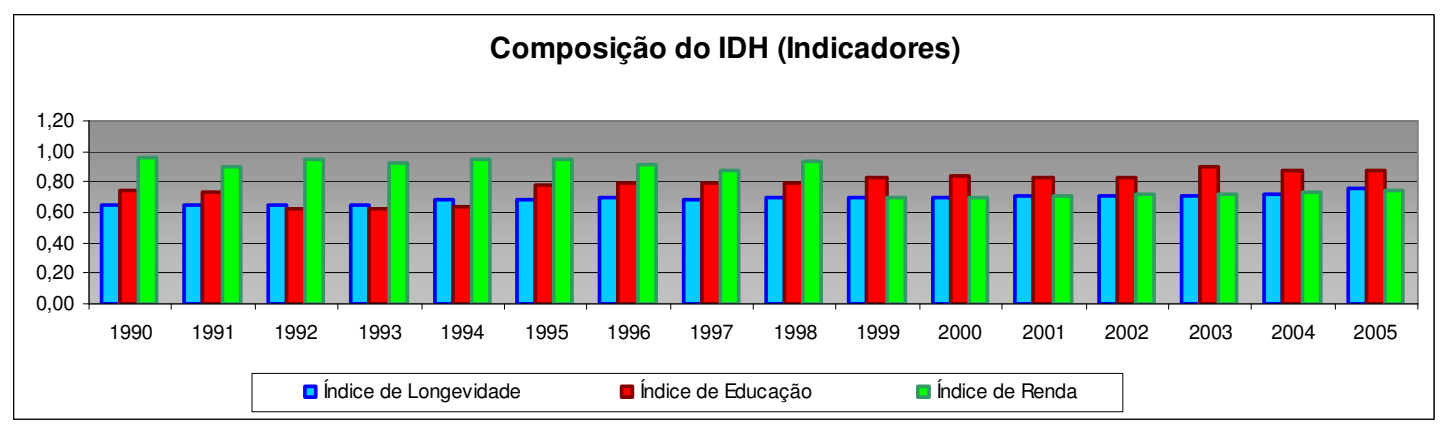

Gráfico 4.16 - Evolução dos componentes do IDH no Brasil

\subsubsection{FLUXOS INTERNACIONAIS DE CAPITAIS}

Os dados relativos ao investimento estrangeiro direto referem-se às entradas e saídas de capitais estrangeiros (sob forma de transferências intercompanhias e participação no capital).

Como pode ser observado no gráfico 4.17, os investimentos estrangeiros diretos apresentam um aumento na década de 90, em especial a partir de 1994. Isso se deu pela integração de mercados, pelo plano de desestatização e pela estabilização ocorrida com o Plano Real. A relação entre os investimentos estrangeiros diretos e o PIB aumentou na década de 90, especialmente entre 1994 e 2000. Isso ocorreu pela abertura econômica ocorrida no processo de globalização e pela estabilização promovida pelo Plano Real. Esses dois fatores aliados à privatização foram responsáveis pela entrada de investimentos na compra de empresas brasileiras. Assim, com a mudança na participação acionária das empresas no Brasil, houve uma atuação mais intensa das empresas transnacionais no país, modificando os padrões de competitividade e o comércio internacional.

A partir de 1999 as principais empresas haviam sido privatizadas e como conseqüência houve uma redução dos investimentos no Brasil. Com a instabilidade provocada pela mudança na 
política cambial em 1999 e com o fim da privatização das grandes empresas, o fluxo de investimentos estrangeiros diretos diminuiu. O gráfico 4.17 apresenta a evolução dos investimentos estrangeiros diretos no Brasil e sua relação com o PIB a partir de 1990.

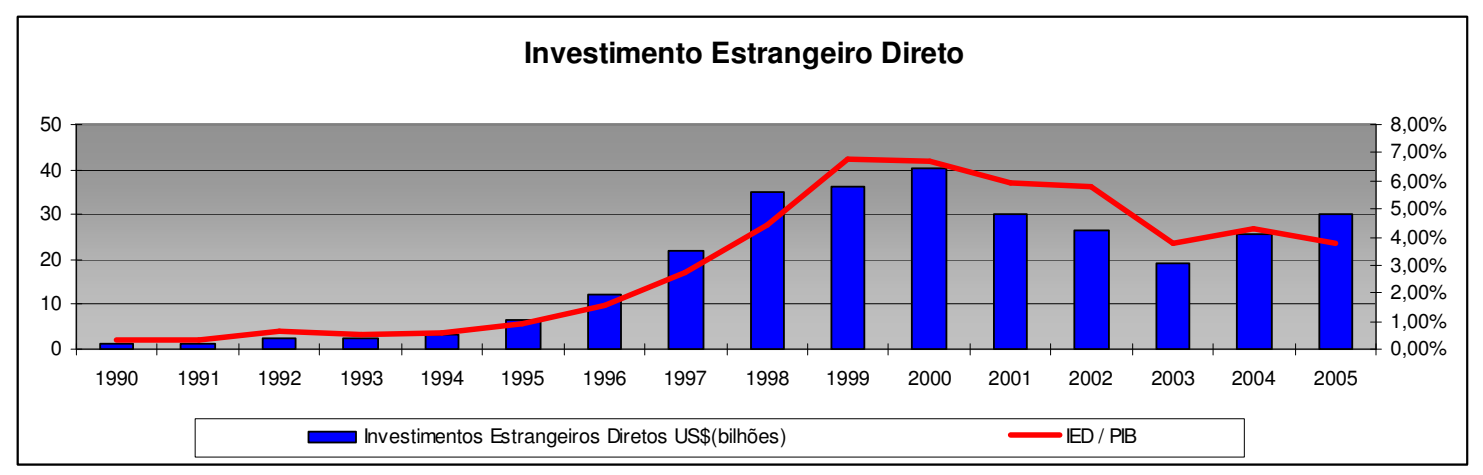

Gráfico 4.17 - Evolução do Investimento Estrangeiro Direto e sua relação com o PIB

O gráfico 4.18 apresenta a composição entre capitais estrangeiros por transações intercompanhias e participação no capital.

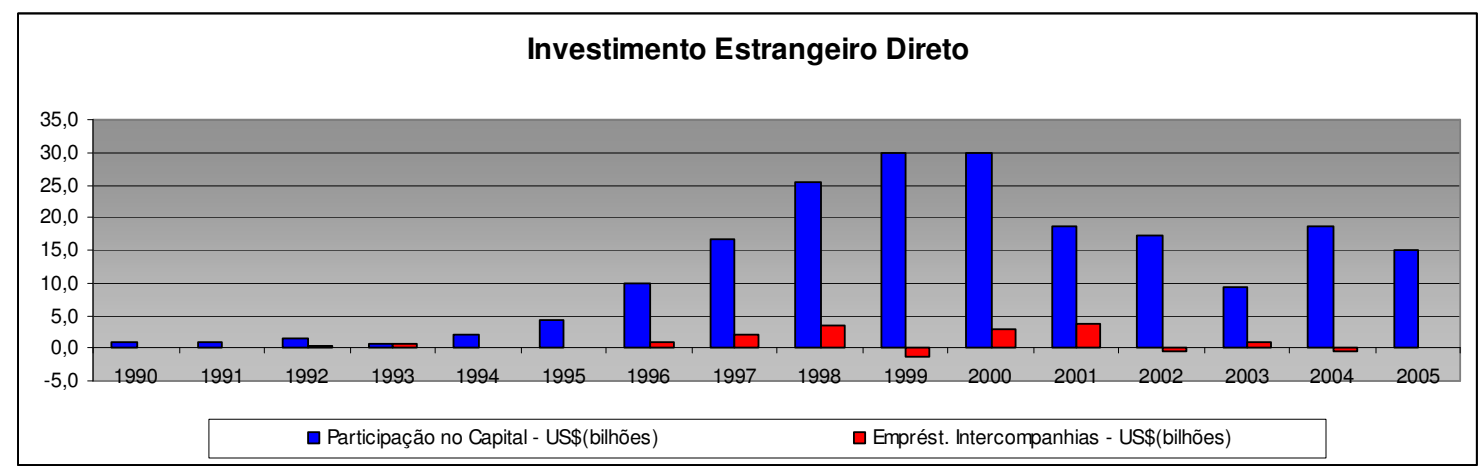

Gráfico 4.18 - Composição do Investimento Estrangeiro Direto 


\subsubsection{FLUXOS INTERNACIONAIS DE BENS}

Conforme já discutido anteriormente, a balança comercial apresentou saldo negativo entre 1995 e 2000 devido, entre outros fatores, à política cambial adotada em 1994. Outro fator relevante foi a abertura comercial, que proporcionou a entrada de produtos estrangeiros no país competindo com os produtos nacionais. Assim, até que a indústria nacional atingisse um certo grau de competitividade, houve mais importação do que exportação. A partir de 2000, especialmente com a mudança na política cambial, houve reversão do quadro deficitário na balança comercial.

Outro ponto relevante é o coeficiente de abertura. Percebe-se que por esse indicador, o volume de exportações e importações em relação ao PIB apresentou crescimento no período analisado (com um pequeno declínio entre 1993 e 1997). Isso significa que a integração do Brasil na economia mundial apresenta tendência de crescimento. O gráfico 4.19 apresenta a evolução do saldo da balança comercial e o coeficiente de abertura entre 1990 e 2005.

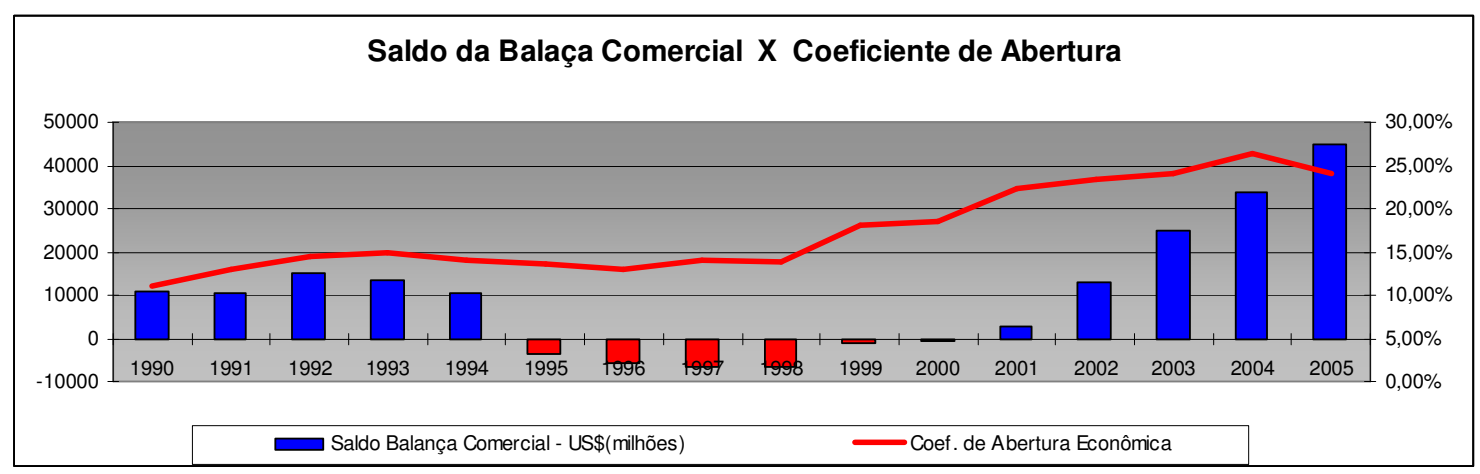

Gráfico 4.19 - Evolução do Saldo da Balança Comercial e do Coeficiente de Abertura

O gráfico 4.20 apresenta a evolução das exportações e importações. Nota-se o aumento das importações e redução das exportações entre 1994 e 2000, conforme discutido anteriormente. Um outro dado importante é que a linha das exportações descola da das importações a partir 
de 2001. Significa dizer, por meio desses dados, que a tendência de crescimento do coeficiente de abertura é explicada, principalmente, pelo aumento das exportações.

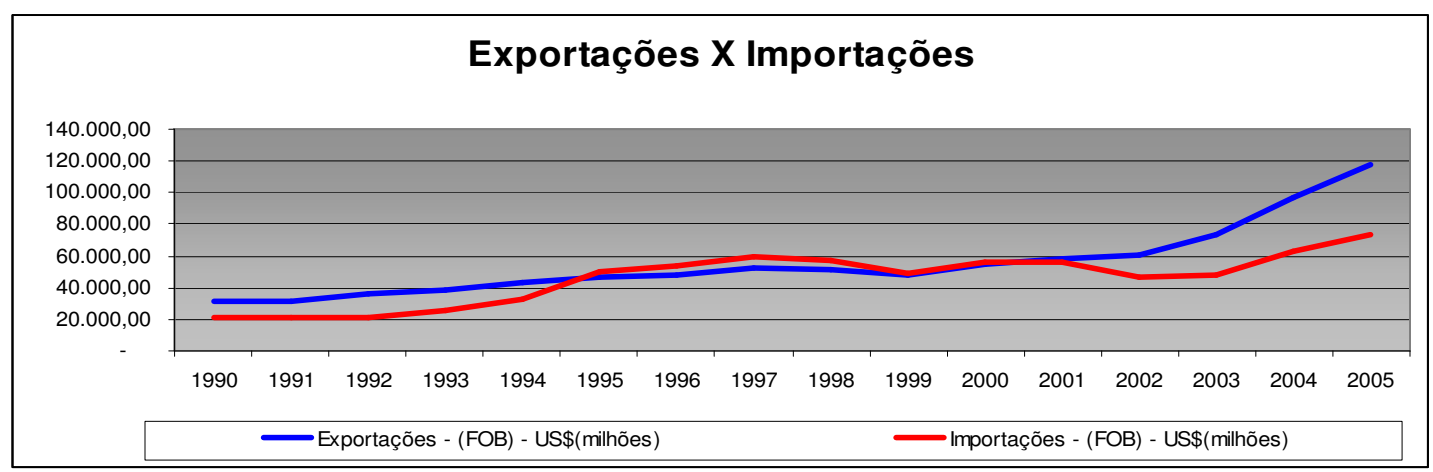

Gráfico 4.20 - Evolução das Exportações e Importações

Uma importante análise é a relação entre as exportações brasileiras e mundiais. Através desse indicador é possível observar que a participação da exportação brasileira na pauta mundial é pequena, girando em torno de $1,0 \%$. Mesmo com um crescimento médio nas exportações na ordem de 16,64\% entre 1999 e 2005, o aumento na participação mundial ainda é muito pequeno. O gráfico 4.21 apresenta os dados da participação brasileira nas exportações mundiais.

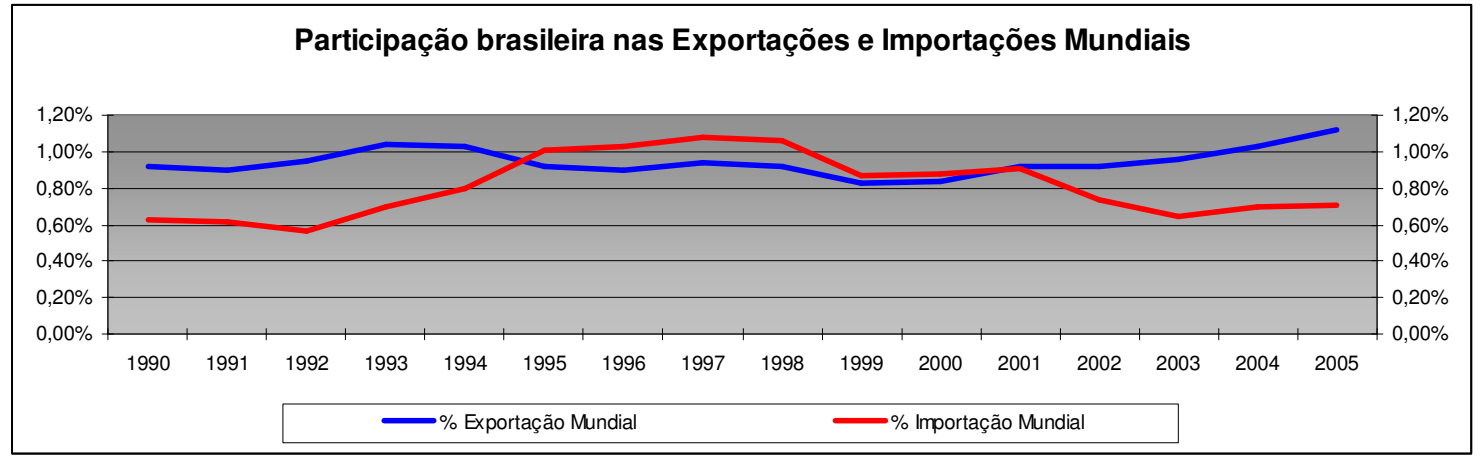

Gráfico 4.21 - Participação brasileira nas exportações e importações mundiais

Um outro dado importante para análise é a participação das exportações no PIB (coeficiente de exportação). O PIB, como já foi discutido, é o principal indicador de crescimento 
econômico. Ao analisar o coeficiente de exportação, busca-se explicar a participação das exportações no crescimento econômico. De acordo com o gráfico 4.22, é possível observar que a participação das exportações no PIB aumentou, em especial a partir de 1999.

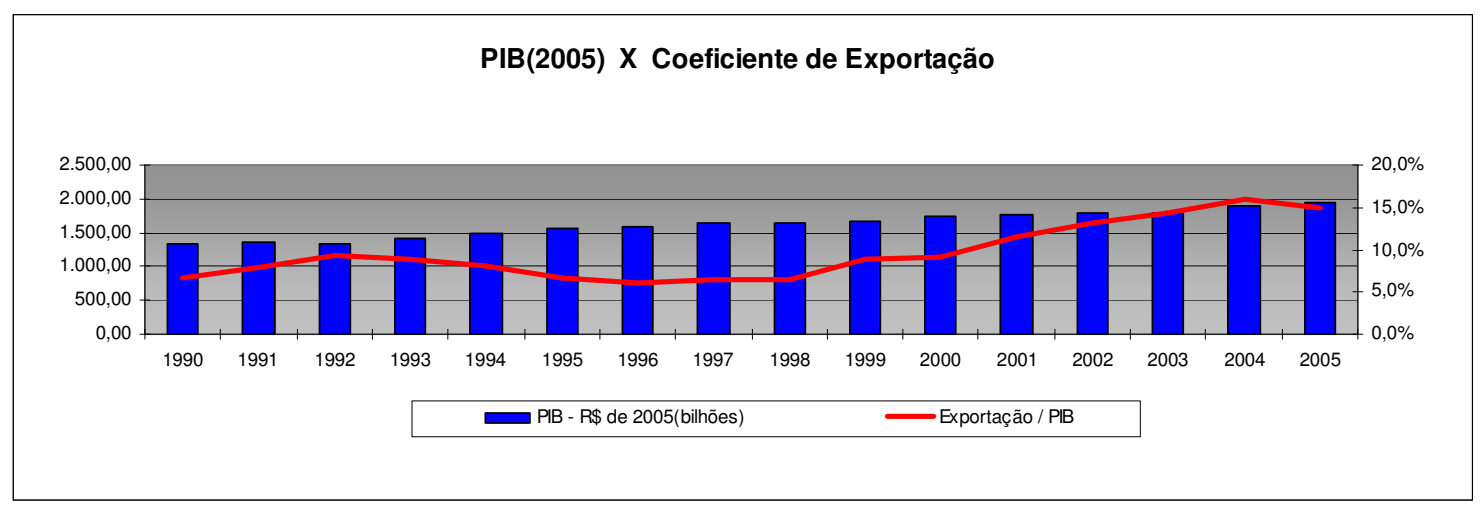

Gráfico 4.22 - Relação entre o PIB (R \$ 2005) e o Coeficiente de Exportação

O crescimento anual médio das exportações no período foi de $8,53 \%$. Esse indicador deve ser analisado em partes. De 1990 a 1994 houve aumento das exportações em decorrência, entre outros fatores, da abertura comercial. Nesse período o crescimento médio das exportações foi de 5,18\% ao ano. Com a adoção do câmbio fixo em 1994, o real ficou valorizado, incentivando importações e reduzindo exportações. Nesse período a média de crescimento das exportações foi de 2,17\% ao ano. No período de 1999 a 2005, o crescimento médio anual foi de $16,64 \%$. O gráfico 4.23 apresenta o crescimento das exportações no período.

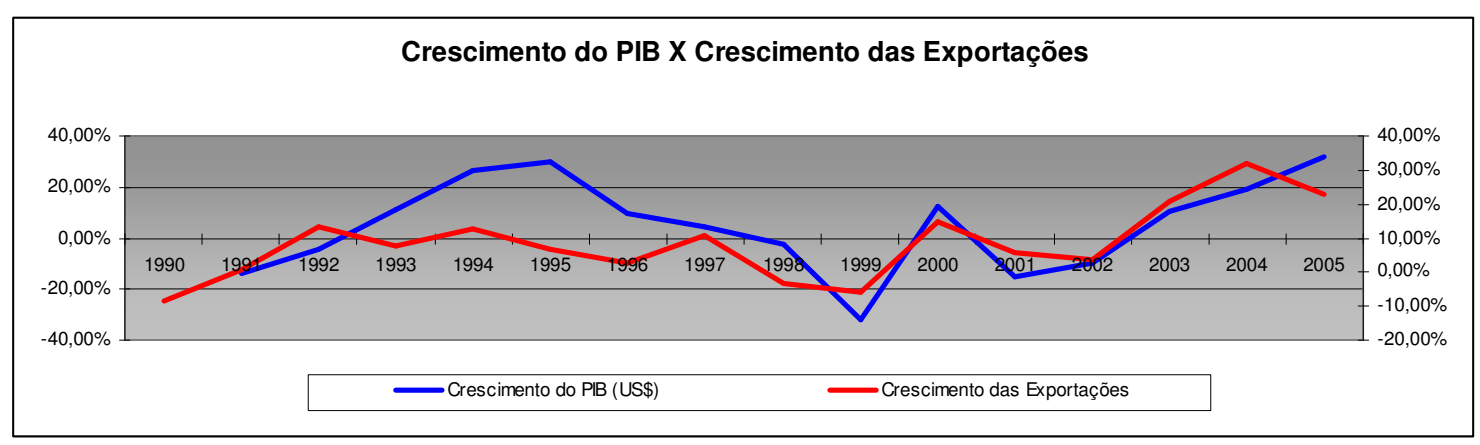

Gráfico 4.23 - Crescimento do PIB (US\$) e o Coeficiente de Exportação 


\section{PROCEDIMENTOS METODOLÓGICOS}

O conhecimento científico, assim como outras formas de conhecimento, tem como objetivo fundamental chegar à veracidade dos fatos e tem como característica fundamental a sua verificabilidade. Para que o conhecimento possa ser considerado científico é necessário determinar o método que possibilitou chegar a esse conhecimento (GIL, 1999).

Dessa forma, esta seção busca especificar os procedimentos metodológicos utilizados neste trabalho e está dividida em: "Método de Pesquisa", em que são especificados o método e o tipo de pesquisa utilizada; "Obtenção e Tratamento de Dados", em que são apresentados os indicadores utilizados, além de explicitar as fontes de dados utilizadas, a periodicidade e seu tratamento; e por fim é apresentada a "Modelagem Econométrica".

\subsection{MÉTODO DE PESQUISA}

O método de pesquisa utilizado neste trabalho é um estudo descritivo, no âmbito positivista.

A pesquisa descritiva observa, descreve, registra, analisa, interpreta e correlaciona fatos ou fenômenos atuais (LAKATOS; MARCONI, 1999 e CERVO; BERVIAN, 1996). Esse tipo de pesquisa busca descobrir, com precisão possível, a freqüência com que um fenômeno ocorre, sua relação e conexão com outros, sua natureza e suas características (CERVO; BERVIAN, 1996). 
É um estudo no âmbito positivista, pois as pesquisas positivistas utilizam estudos descritivos para expor as características de um fenômeno e estabelecer relações entre variáveis e fatos (MARTINS, 1995). O positivismo lógico é composto pelo Método Indutivo, que é um processo pelo qual, partindo de dados ou observações particulares, pode-se chegar a proposições gerais.

Para Richardson (1999) e Lakatos e Marconi (2003), o Método Indutivo é um processo pelo qual, partindo de dados particulares, suficientemente constatados, infere-se em uma verdade geral, não contida nas partes examinadas. $\mathrm{O}$ argumento indutivo fundamenta-se em premissas e pode-se afirmar que as premissas de um argumento indutivo correto sustentam ou atribuem certa verossimilhança à conclusão. Assim, quando as premissas são verdadeiras, a conclusão é provavelmente verdadeira (CERVO; BERVIAN, 1978).

O processo de indução realiza-se em três etapas: (1) observação dos fenômenos, com a finalidade de descobrir as causas de sua manifestação; (2) descoberta da relação entre os fenômenos, por intermédio da comparação para descobrir a relação constante existente entre eles; e (3) generalização da relação (LAKATOS; MARCONI, 2003)

Trata-se também de uma pesquisa aplicada, pois se caracteriza por seu interesse prático para que seus resultados sejam aplicados ou utilizados na solução de problemas que ocorrem na realidade (LAKATOS; MARCONI, 1999). Considerando que este estudo tem como objetivo discutir uma das alternativas sugeridas para promover o desenvolvimento por meio do crescimento econômico, este trabalho é uma pesquisa aplicada. 


\subsection{OBTENÇÃO E TRATAMENTO DOS DADOS}

Para a realização da pesquisa é necessária a utilização de dados econômicos para análise. Assim, a escolha dos indicadores para análise, as fontes, a periodicidade e o tratamento dos dados serão detalhados a seguir.

\subsubsection{INDICADORES UTILIZADOS}

Este estudo busca analisar o período de abertura comercial promovida no contexto da globalização. Dessa forma, o período de análise deste estudo será de 1990 a 2005. De acordo com os indicadores sugeridos pela revisão bibliográfica, os dados são separados em indicadores de crescimento, desenvolvimento, fluxos de bens e fluxos de capitais. Os dados relativos aos indicadores de desenvolvimento não são publicados trimestralmente.

Para conferir maior consistência estatística, as variáveis foram consideradas com periodicidade trimestral, o que possibilitou a construção de séries com 64 registros no período considerado. A análise de séries históricas com poucos dados (observações) inviabiliza a análise. Assim, para o período de análise (1990-2005) são descartados os dados anuais, pois possibilitam a análise de apenas 16 registros. Dessa forma, são consideradas apenas variáveis trimestrais, que totalizam 64 registros para cada variável. Para análise dos dados anuais, o primeiro passo é a realização do teste não-paramétrico de Kolmogorov-Smirnov (K-S), e em seguida a análise de regressão.

Para esta pesquisa foram usadas as seguintes fontes de dados: Instituto de Pesquisa Econômica Aplicada (IPEA), Instituto Brasileiro de Geografia e Estatística (IBGE), Banco 
Central do Brasil (BCB) e dados dos relatórios anuais do Programa das Nações Unidas para o Desenvolvimento (PNUD).

A seguir, os quadros 5.1 e 5.2 apresentam os indicadores, a periodicidade e a fonte de dados utilizadas neste trabalho.

\begin{tabular}{|l|l|c|c|c|}
\hline Grupo & Indicador & Período & Periodicidade & Fonte \\
\hline \multirow{4}{*}{ Crescimento Econômico } & PIB (US\$) & $1990-2005$ & Trimestral & IPEA \\
\cline { 2 - 5 } & Produtividade (índice) & $1990-2005$ & Trimestral & BCB \\
\cline { 2 - 5 } & Investimento Interno / PIB (\%) & $1990-2005$ & Trimestral & IPEA \\
\cline { 2 - 5 } & Poupança / PIB (\%) & $1990-2005$ & Trimestral & IBGE \\
\cline { 2 - 5 } & Royalties e Licenças (US\$) & $1990-2005$ & Trimestral & IPEA \\
\hline Fluxo de Capitais & Inv. Estrangeiros Diretos (US\$) & $1990-2005$ & Trimestral & BCB \\
\hline \multirow{3}{*}{ Fluxo de Bens } & Exportações (US\$) & $1990-2005$ & Trimestral & IPEA \\
\cline { 2 - 5 } & Coeficiente de Abertura (\%) & $1990-2005$ & Trimestral & IPEA \\
\hline
\end{tabular}

Quadro 5.1 - Relação dos indicadores para a análise de causalidade de Granger

A Renda Nacional Bruta foi retirada da análise por ter alta correlação com o Produto Interno Bruto, além de também medir crescimento econômico.

\begin{tabular}{|l|l|l|c|c|}
\hline Grupo & Indicador & Período & Periodicidade & Fonte \\
\hline \multirow{5}{*}{ Crescimento Econômico } & PIB & $1990-2005$ & Anual & IPEA \\
\cline { 2 - 5 } & Produtividade & $1990-2005$ & Anual & BCB \\
\cline { 2 - 5 } & Capital (estoque) & $1990-2005$ & Anual & IPEA \\
\cline { 2 - 5 } & Capital humano (anos de estudo PIA) & $1990-2005$ & Anual & IBGE \\
\cline { 2 - 5 } & Capital humano (analfabetismo) & $1990-2005$ & Anual & IBGE \\
\cline { 2 - 5 } & Poupança / PIB & $1990-2005$ & Anual & IPEA \\
\cline { 2 - 5 } & Investimentos / PIB & $1990-2005$ & Anual & IPEA \\
\hline \multirow{5}{*}{ Desenvolvimento Econômico } & Produto (PIB) per capita & $1990-2005$ & Anual & IPEA \\
\cline { 2 - 5 } & Rendimento Domiciliar per capita & $1990-2005$ & Anual & IPEA \\
\cline { 2 - 5 } & Índice de Gini & $1990-2005$ & Anual & IPEA \\
\cline { 2 - 5 } & Índice de Desenv. Humano IDH & $1990-2005$ & Anual & RDH \\
\cline { 2 - 5 } & Índice de Longevidade & $1990-2005$ & Anual & RDH \\
\cline { 2 - 5 } & Índice de Educação & $1990-2005$ & Anual & RDH \\
\cline { 2 - 5 } & Índice de Renda & $1990-2005$ & Anual & RDH \\
\hline Fluxo de Capitais & IED / PIB & $1990-2005$ & Anual & BCB \\
\hline \multirow{3}{*}{ Fluxo de Bens } & Coeficiente de Abertura & $1990-2005$ & Anual & IPEA \\
\cline { 2 - 5 } & Coeficiente de Exportação & $1990-2005$ & Anual & IPEA \\
\hline
\end{tabular}

Quadro 5.2 - Relação dos indicadores a para análise de regressão 
O indicador Renda Nacional Bruta foi retirado da análise pela alta correlação com o PIB. Para facilitar a análise, os indicadores de concentração de renda são sintetizados no índice de Gini. Dessa forma, os outros indicadores de concentração de renda (índice de Theil, rendimento domiciliar dos $1 \%$ mais ricos, rendimento domiciliar dos $50 \%$ mais pobres e percentual de pessoas pobres), por medirem o mesmo que o índice de Gini, foram excluídos da análise.

\subsubsection{TRATAMENTO DOS DADOS}

Com o objetivo de eliminar flutuações de curto prazo (sazonalidade, tendências e oscilações) nas séries temporais são usados processos de alisamento dessas séries. A suavização faz com que a série temporal seja mais fácil de analisar (PINDYCK; RUBINFELD, 2004). A estimação da tendência pode ser obtida de várias maneiras: (1) método dos mínimos quadrados; (2) método a sentimento; (3) método das médias móveis e (4) método das semimédias (SPIEGEL, 1994).

Para evitar o critério individual na construção de retas, parábola ou outras curvas de ajustamento que se adaptem ao conjunto de dados, é necessário instituir a definição da melhor curva de ajustamento. De todas as curvas que se ajustam a um conjunto de pontos, a que tem a propriedade de apresentar o valor mínimo de desvio (erro ou resíduo) é denominada "a melhor curva de ajustamento". A curva que apresenta essa propriedade, e ajusta os dados no sentido dos mínimos quadrados, é denominada curva dos mínimos quadrados (SPIEGEL, 1994).

Segundo Maddala (2003), o método dos mínimos quadrados requer que sejam escolhidos $\alpha$ e $\beta$, respectivamente de forma a minimizar: 
$Q=\sum_{i=1}^{n}\left(y_{i}-\hat{\alpha}-\hat{\beta} x_{i}\right)^{2}$

Em que:

$\alpha$ e $\beta$ são os coeficientes ou parâmetros da regressão que são estimados sobre dados de $\mathrm{x}$ e y $\hat{\alpha}$ e $\hat{\beta}$ são estimadores de $\alpha$ e $\beta$

Para minimizar Q na equação em relação à $\hat{\alpha}$ e $\hat{\beta}$, calcula-se as primeiras derivadas em relação à $\hat{\alpha}$ e $\hat{\beta}$ e iguala-se a zero. Assim, tem-se:

$\frac{\partial Q}{\partial \hat{\alpha}}=0 \Rightarrow \sum 2\left(y_{i}-\hat{\alpha}-\hat{\beta} x_{i}\right)(-1)=0 \quad$ ou $\quad \sum y_{i}=n \hat{\alpha}+\hat{\beta} \sum x_{i}$

ou $\quad \bar{y}=\hat{\alpha}+\hat{\beta} \bar{x}$

$\mathrm{e}$

$\frac{\partial Q}{\partial \hat{\beta}}=0 \Rightarrow \sum 2\left(y_{i}-\hat{\alpha}-\hat{\beta} x_{i}\right)\left(-x_{i}\right)=0 \quad$ ou $\quad \sum y_{i} x_{i}=\hat{\alpha} \sum x_{i}+\hat{\beta} \sum x_{i}^{2}$

As equações $\bar{y}=\hat{\alpha}+\hat{\beta} \bar{x} \quad$ e $\sum y_{i} x_{i}=\hat{\alpha} \sum x_{i}+\hat{\beta} \sum x_{i}^{2}$ são chamadas equações normais.

Considerando que a equação (1) é $\bar{y}=\hat{\alpha}+\hat{\beta} \bar{x}$ e a equação (2) é $\sum y_{i} x_{i}=\hat{\alpha} \sum x_{i}+\hat{\beta} \sum x_{i}^{2}$, tem-se ao substituir o valor de $\hat{\alpha}$ de (1) em (2):

$\sum y_{i} x_{i}=\sum x_{i}(\bar{y}-\hat{\beta} \bar{x})+\hat{\beta} \sum x_{i}^{2}=n \bar{x}(\bar{y}-\hat{\beta} \bar{x})+\hat{\beta} \sum x_{i}^{2}$ 


$$
\begin{aligned}
& S_{y y}=\sum\left(y_{i}-\bar{y}\right)^{2}=\sum y_{i}^{2}-n \bar{y}^{2} \\
& S_{x y}=\sum\left(x_{i}-\bar{x}\right)\left(y_{i}-\bar{y}\right)=\sum x_{i} y_{i}-n \overline{x y} \\
& S_{x x}=\sum\left(x_{i}-\bar{x}\right)^{2}=\sum x_{i}^{2}-n \bar{x}^{2}
\end{aligned}
$$

Assim, a equação $\sum y_{i} x_{i}=\sum x_{i}(\bar{y}-\hat{\beta} \bar{x})+\hat{\beta} \sum x_{i}^{2}=n \bar{x}(\bar{y}-\hat{\beta} \bar{x})+\hat{\beta} \sum x_{i}^{2}$ pode ser escrita como:

$$
\hat{\beta} S_{x x}=S_{x y} \quad \text { ou } \quad \hat{\beta}=\frac{S_{x y}}{S_{x x}}
$$

Portanto os estimadores de mínimos quadrados para $\alpha$ e $\beta$ são:

$$
\hat{\beta}=\frac{S_{x y}}{S_{x x}} \quad \text { e } \quad \hat{\alpha}=\bar{y}-\hat{\beta} \bar{x}
$$

Os resíduos estimados são $u_{i}=y_{i}-\hat{\alpha}-\hat{\beta} x_{i}$

A soma dos quadrados dos resíduos é calculada por:

$$
S Q R=\sum\left(y_{i}-\hat{\alpha}-\hat{\beta} x_{i}\right)^{2}=\sum\left(y_{i}-\bar{y}-\hat{\beta}\left(x_{i}-\bar{x}\right)^{2}=S_{y y}+\hat{\beta}^{2} S_{x x}-2 \hat{\beta} S_{x y}\right.
$$

Como $\hat{\beta}=\frac{S_{x y}}{S_{x x}}$, tem-se $S Q R=S_{y y}-\frac{S_{x y}^{2}}{S_{x x}}=S_{y y}-\hat{\beta} S_{x y}$

$S_{x y}$ é normalmente denotado por SQT (soma dos quadrados totais) e $\hat{\beta} S_{x y}$ como SQE (soma dos quadrados explicados). Assim, SQT (total) = SQE (explicado) + SQR (resíduos). A proporção da soma total dos quadrados explicados é denotada por $r_{x y}^{2}$. O coeficiente de determinação $r_{x y}^{2}$ é dado por: 


$$
r_{x y}^{2}=\frac{S Q E}{S Q T}=\frac{S Q T-S Q R}{S Q T}=\frac{\hat{\beta} S_{x y}}{S_{y y}}
$$

Segundo Maddala (2003), os estimadores de mínimos quadrados descrevem uma reta estimada que tem resíduos (SQR) menores do que qualquer outra reta. O uso do método dos mínimos quadrados permite a modelagem de séries inter-relacionadas (por meio do modelo de auto-regressão vetorial - VAR), a verificação da existência de raízes unitárias (utilizando o teste Dickey Fuller Aumentado para testar relações de causalidade segundo Granger) e a estimação da equação de regressão para se detectar a cointegração.

\subsection{MODELAGEM ECONOMÉTRICA}

A análise da relação entre fenômenos é objeto de estudo de muitos pesquisadores. Para isso, são utilizados vários testes e análises estatísticas. De acordo com Carneiro (1997), a análise de regressão lida com a dependência de uma variável com relação às outras. No entanto, a análise de regressão pura e simples não implica em causalidade. Kendall e Stuart (1961) afirmam que "a identificação de uma relação estatística entre duas ou mais variáveis, por mais forte que seja, pode nunca estabelecer uma relação causal entre elas".

O termo causalidade, no sentido estatístico, não é sinônimo de endogeneidade e, por isso, Leamer (1985) sugere o termo "precedência temporal" em lugar do termo causalidade. De acordo com Carneiro (1997), para identificar uma relação de causalidade ou precedência 
temporal, os principais testes são: o Teste de Sims, o Teste de Causalidade de Granger e o Teste de Variáveis Cointegradas.

Para a realização do teste de causalidade, Granger (1969) baseia-se em duas premissas: a) a previsibilidade é um conceito análogo ao de causalidade; e b) a relação entre causa e efeito é temporária no sentido de que este não pode surgir antes daquela. Assim, "uma variável qualquer X causa ou procede outra variável $\mathrm{Y}$, se a incorporação dos valores passados de $\mathrm{X}$ em um conjunto de informações que inclua essas variáveis contribui para melhorar a previsão de Y”(MATOS, 2003).

De acordo com Carneiro (1997) e Pindyck e Rubinfeld (2004), o teste de causalidade de Granger assume que a informação relevante para a predição das respectivas variáveis X e Y esta contida apenas nas séries temporais sobre essas duas variáveis.

O teste envolve estimar as seguintes regressões:
(1) - $\quad X_{t}=\sum_{i=1}^{m} a_{i} Y_{t-i}+\sum_{i=1}^{m} b_{i} X_{t-i}+u_{1 t} \quad \mathrm{e}$
(2) - $\quad Y_{t}=\sum_{i=1}^{m} c_{i} Y_{t-i}+\sum_{i=1}^{m} d_{i} X_{t-i}+u_{2 t}$

em que, $u_{i t}$ são os resíduos que assume-se serem não correlacionados.

Após a estimação, pode-se diferenciar quatro casos: Causalidade unilateral de $\mathrm{Y}$ para X, Causalidade unilateral de X para Y, Bicausalidade ou Simultaneidade, e Independência (CARNEIRO, 1997). Um teste alternativo para causalidade deve-se a Sims (1972), que também parte do pressuposto de que o futuro não pode causar o presente. Considerando a hipótese de que busca-se analisar se X causa $\mathrm{Y}$, tem-se a seguinte regressão que inclui valores 
passados, presentes e futuros de $\mathrm{X}$, em que $\mathrm{k}$ denota o número de defasagens e $\mathrm{m}$ o número de valores futuros:

$Y_{t}=a+b_{k} X_{t-k}+b_{k-1} X_{t-k+1}+\ldots+b_{1} X_{t-1}+b_{0} X_{t}+g_{1} X_{t+1}+g_{2} X_{t+2}+\ldots+g_{m} X_{t+m}+u_{t}$

Se $\mathrm{X}$ causa $\mathrm{Y}$, então a soma dos coeficientes dos termos nos valores futuros de $\mathrm{X}$ deve ser estatisticamente igual a zero. Assim, apesar de o teste de Sims apresentar diferenças econométricas em relação ao teste de causalidade de Granger, os dois testes partem do mesmo pressuposto e testam a mesma hipótese: a de que o futuro não pode causar o presente. É importante salientar que os testes de Granger e Sims são equivalentes para duas variáveis, porém, a equivalência não ocorre para análise que considerem mais do que duas séries temporais (DURLAUF, 2005).

“A existência do efeito de causalidade Granger entre duas séries temporais é um indicativo de que o modelo de auto-regressão vetorial (VAR) pode ser desenvolvido para modelar e projetar as séries inter-relacionadas" (PIMENTA JUNIOR, 2000, p.79). Para Maddala (2003), o modelo VAR é um ponto inicial muito útil na análise de inter-relações entre as séries temporais. Segundo o autor, esse modelo é indicado pela facilidade de estimação com o uso do Método dos Mínimos Quadrados.

Assim, o teste de Granger é um procedimento anterior ao uso do modelo VAR, que permite, com o uso do Método dos Mínimos Quadrados, modelar e projetar séries inter-relacionadas. A análise de um modelo VAR é realizada por meio de um processo de decomposição de variâncias e observação de funções de resposta a impulsos. 


\subsubsection{MENSURAÇÃO DE CAUSALIDADE ENTRE VARIÁVEIS}

O modelo adotado para este trabalho, para o estudo de interdependência das variáveis, é o modelo de auto-regressão vetorial (VAR). Os modelos VAR são uma variante dos modelos auto-regressivos (AR) univariados e são indicados para o estudo do comportamento no tempo e previsão dos valores de duas ou mais variáveis econômicas, com as variáveis apresentadas sob forma de séries temporais (PIMENTA JUNIOR, 2000). O VAR estima um sistema dinâmico de equações "simultâneas", livre de premissas restritivas na estrutura dos relacionamentos (PIMENTA JUNIOR, 2000).

De acordo com Matos (2000, p. 255) "os modelos VAR, ao contrário dos sistemas de equações simultâneas, têm sido considerados mais apropriados para a análise de relações interligadas e dos impactos dinâmicos provocados por disturbâncias aleatórias”. Para o autor, entre as aplicações desses modelos, destacam-se a análise de impulsos-respostas e o teste de causalidade de Granger. Maddala (2003) considera que o modelo VAR deve ser utilizado, como alternativa ao modelo de equações simultâneas, pela facilidade de uso. Matos (2000) defende o modelo VAR por três razões:

A primeira refere-se à simplicidade da formulação em virtude de não existir preocupação quanto à determinação das variáveis endógenas e exógenas, pois todas são endógenas, embora variáveis puramente exógenas possam ser incluídas nesse modelo para se considerar, por exemplo, tendências e fatores sazonais. Em segundo lugar, o modelo VAR pode ser facilmente estimado mediante a aplicação do método dos mínimos quadrados ordinários em cada equação isoladamente. A terceira virtude do VAR refere-se à qualidade, muitas vezes melhor, da previsão de valores em relação aos complexos modelos de equações simultâneas. (MATOS, 2000, p. 256-257)

O modelo VAR teve sua aplicação pioneira no estudo desenvolvido por Sims (1980), cujo propósito foi o de usar uma equação de estimação na forma reduzida e não restrita, que tivesse conjuntos uniformes de variáveis dependentes defasadas, como regressores (PIMENTA JUNIOR, 2000). 
Um modelo VAR(p), bidimensional, ou seja, para o estudo de duas variáveis x e y e duas equações, de ordem $\mathrm{p}$ (que trabalha com defasagens de ordem até p), pode ser representado como (HILL; GRIFFITHS; JUDGE, 2006):

$$
\begin{aligned}
& y_{t}=\theta_{0}+\theta_{1} y_{t-1}+\ldots+\theta_{p} y_{p-1}+\phi_{1} x_{t-1}+\phi_{2} x_{t-2}+\ldots+\phi_{p} x_{t-p}+e_{t} \\
& x_{t}=\delta_{0}+\delta_{1} y_{t-1}+\ldots+\delta_{p} y_{p-1}+\alpha_{1} x_{t-1}+\alpha_{2} x_{t-2}+\ldots+\alpha_{p} x_{t-p}+u_{t}
\end{aligned}
$$

Em que:

x e y são variáveis (dependentes e independentes).

os coeficientes $\theta, \phi, \delta$ e $\alpha$ são parâmetros desconhecidos.

$e_{t}$ e $u_{t}$ são termos estocásticos.

De acordo com o modelo, o valor atual de uma variável $y_{t}$ pode ser explicado por valores defasados da própria variável e também da variável $x_{t}$, não dependendo do valor atual de $x_{t}$, mais um termo estocástico $e_{t}$. Assume-se que o termo estocástico $e_{t}$ tenha média zero, variância constante $\sigma_{e}^{2}$, e seja serialmente não correlacionado (PIMENTA JUNIOR, 2000, p.71).

Os termos $e_{t}$ e $u_{t}$ são importantes na modelagem VAR, pois absorvem quaisquer choques provenientes de fatores econômicos externos ao sistema das equações, como por exemplo, alterações em políticas econômicas, eventos financeiros nacionais e internacionais ou crises econômicas. Os efeitos desses choques podem estar presentes simultaneamente em ambos os termos estocásticos, possibilitando uma correlação entre $e_{t}$ e $u_{t}$, chamada de correlação contemporânea (PIMENTA JUNIOR, 2000). 
Um modelo básico de auto-regressão de uma série temporal pode ser expresso como:

$y_{t}=c+\phi_{1} y_{t-1}+\phi_{2} y_{t-2}+\phi_{3} y_{t-3}+\ldots+\phi_{p} y_{t-p}+\varepsilon_{t}$

$E\left[\varepsilon_{t}\right]=0 \quad E\left[\varepsilon_{t} \varepsilon_{\tau}\right]=\left\{\sigma^{2}\right.$, para $t=\tau$; e 0 , para $\left.t \neq \tau\right\}$

Um VAR(p) é uma generalização vetorial da equação acima:

$$
y_{t}=c+\Phi_{1} y_{t-1}+\Phi_{2} y_{t-2}+\Phi_{3} y_{t-3}+\ldots+\Phi_{p} y_{t-p}+\varepsilon_{t}
$$

Em que:

c é um vetor $(\mathrm{n} \times 1)$ de constantes;

$\Phi$ é uma matriz $(\mathrm{n} \times \mathrm{n})$ de coeficientes auto-regressivos

$\varepsilon$ é um vetor $(\mathrm{n} \times 1)$, generalização de um ruído branco, com:

$E\left[\varepsilon_{t}\right]=0 \quad E\left[\varepsilon_{t} \varepsilon_{\tau}\right]=\{\Omega$, para $t=\tau$; e 0 , para $t \neq \tau\}$

$\Omega$ é uma matriz simétrica positiva de ordem n. 


\subsubsection{O PROBLEMA DA ESTACIONARIDADE}

Segundo Maddala (2003), do ponto de vista teórico, uma série temporal é uma coleção de variáveis aleatórias $\left\{X_{t}\right\}$ e, uma coleção de variáveis aleatórias como essa, é chamada processo estocástico (aleatório).

Uma das formas de descrever um processo estocástico é especificar a distribuição conjunta das variáveis $X_{t}$. Contudo, na prática, o que se faz com freqüência é definir o primeiro e o segundo momentos das variáveis $\mathrm{X}_{\mathrm{t}}$. Uma série temporal é dita estacionária se a distribuição conjunta de qualquer conjunto de $n$ observações $X\left(t_{1}\right), X\left(t_{2}\right), \ldots, X\left(t_{n}\right)$ é a mesma que a distribuição conjunta de $\mathrm{X}\left(\mathrm{t}_{1}+\mathrm{k}\right), \mathrm{X}\left(\mathrm{t}_{2}+\mathrm{k}\right), \ldots, \mathrm{X}\left(\mathrm{t}_{\mathrm{n}}+\mathrm{k}\right)$ (MADDALA, 2003).

A utilização de um processo auto-regressivo requer que as séries temporais sejam estacionárias. Isso significa que a média, a variância e a função de auto-covariância dos dados não se alteram ao longo do tempo (PIMENTA JUNIOR, 2000). Essa exigência vale para (1) o processo puramente aleatório; (2) o passeio aleatório; (3) o processo média móvel (MM), (4) os processos auto-regressivos (AR); (5) os processos de médias móveis auto-regressiva (MMAR), (6) os processos combinados (ARMA); e (7) o processo de média móvel integrada auto-regressiva (ARIMA) (PIMENTA JUNIOR, 2000 e MADDALA, 2003).

Ao desenvolver modelos de séries temporais, queremos saber se o processo estocástico subjacente que gerou a série não varia em relação ao tempo. Se as características do processo estocástico mudam com o tempo, isto é, se o processo é não estacionário, muitas vezes será difícil representar a série temporal em intervalos de tempos passados e futuros através de modelos algébricos simples. Ao contrário, se o processo estocástico é fixo no tempo, ou seja, se é estacionário, podemos modelar o processo através de uma equação com coeficientes fixos que podem ser estimados a partir dos dados passados. (PINDYCK; RUBINFELD, 2004, p.567) 
É possível obter a estacionaridade dos dados para muitas séries temporais através de sucessivas etapas de tomada de diferenças. Um tipo de filtro, muito útil para remover uma componente de tendência, consiste em diferenciar a série até que ela se torne estacionária. (EHLERS, 2003). Ainda segundo o autor, para dados não sazonais, a primeira diferença é em geral suficiente para induzir estacionaridade aproximada. Com a diferenciação obtém-se uma nova série $y_{2}, \ldots, y_{n}$ formada a partir da série original $x_{1}, \ldots, x_{n}$ como $y_{t}=x_{t}-x_{t-1}=\nabla x_{t}$.

O número de etapas de diferenças necessárias caracteriza a ordem do processo. Se os dados de uma série precisam ser diferenciados apenas uma vez para a obtenção da estacionaridade, essa série é um processo integrado de ordem 1, ou seja, I(1) (PIMENTA JUNIOR, 2000).

De acordo com Ehlers (2003), a diferenciação de primeira ordem é a mais utilizada, sendo que ocasionalmente uma diferenciação de segunda ordem pode ser requerida $\left(y_{t}=\nabla^{2} x_{t}=\nabla\left(x_{t}-x_{t-1}\right)=x_{t}-2 x_{t-1}+2 x_{t-2}\right)$.

Quando várias séries temporais são utilizadas, é necessário levar em consideração a interdependência entre elas. Uma das maneiras de fazê-lo é estimar o modelo das equações simultâneas com defasagens em todas as variáveis. Contudo, essa formulação envolve a classificação das variáveis, em endógena e exógena, e especificação do maior número de defasagens necessárias para capturar a maioria dos efeitos que as variáveis tem umas sobre as outras (MADDALA, 2003 e PINDYCK; RUBINFELD, 2004).

Sims (1980), Madalla (2003) e Matos (2000) sugerem que esses dois passos envolvem muitas decisões arbitrárias e sugere como alternativa a abordagem das auto regressões vetoriais (VAR). 
Segundo Pimenta Junior (2000), um VAR(p) pode ser representado:

$$
y_{t}=c+\Phi_{1} y_{t-1}+\Phi_{2} y_{t-2}+\Phi_{3} y_{t-3}+\ldots+\Phi_{p} y_{t-p}+\varepsilon_{t}
$$

Em que:

c é um vetor $(\mathrm{n} \times 1)$ de constantes

$\Phi$ é uma matriz $(\mathrm{n} \times \mathrm{n})$ de coeficientes auto-regressivos

$\mathcal{E}$ é um vetor $(\mathrm{n} \times 1)$, generalização de um ruído branco, com:

$E\left[\varepsilon_{t}\right]=0 \quad E\left[\varepsilon_{t} \varepsilon_{\tau}\right]=\{\Omega$, para $t=\tau$; e 0 , para $t \neq \tau\}$, com $\Omega$ é uma matriz simétrica positiva de ordem $n$.

Esse sistema pode ser representado pela notação do operador de defasagem L (lag operator):

$\left[I_{n}-\Phi_{1} L-\Phi_{2} L^{2}-\Phi_{3} L^{3}-\ldots-\Phi_{p} L^{p}\right] y_{t}=c+\varepsilon_{t}$

ou $\Phi(L) y_{t}=c+\varepsilon_{t}$

Em que:

$\Phi(L)$ representa uma matriz $(\mathrm{n} \times \mathrm{n})$ polinomial de operador $\mathrm{L}$.

O elemento ij dessa matriz é um polinômio escalar em L:

$\Phi(L)=\left[\delta_{i j}-\phi_{i j}^{(1)} L^{1}-\phi_{i j}^{(2)} L^{2}-\ldots \phi_{i j}^{(p)} L^{p}\right] \operatorname{com} \delta_{i j}=\{1$, se i=j; e 0 se $\mathrm{i} \neq \mathrm{j}\}$ 
Um processo vetorial $y_{t}$ é dito estacionário se os seus primeiro e segundo momentos $\left(E\left[y_{t}\right]\right.$ e $\left.E\left[y_{t} y_{t-j}^{\prime}\right\rfloor\right)$ são independentes da data t.

Se o processo é estacionário, as esperanças de ambos os lados podem ser extraídas para se calcular a média do processo (PIMENTA JUNIOR, 2000):

$$
\begin{aligned}
& y_{t}=c+\Phi_{1} y_{t-1}+\Phi_{2} y_{t-2}+\Phi_{3} y_{t-3}+\ldots+\Phi_{p} y_{t-p}+\varepsilon_{t} \\
& \mathrm{E}\left[y_{t}\right]=\mathrm{E}\left[c+\Phi_{1} y_{t-1}+\Phi_{2} y_{t-2}+\Phi_{3} y_{t-3}+\ldots+\Phi_{p} y_{t-p}+\varepsilon_{t}\right\rfloor \\
& \mu=c+\Phi_{1} \mu+\Phi_{2} \mu+\Phi_{3} \mu+\ldots+\Phi_{p} \mu \\
& \mu=\left(I_{n}-\Phi_{1}-\Phi_{2}-\Phi_{3}-\ldots-\Phi_{p}\right)^{-1} c
\end{aligned}
$$

Assim, o sistema pode ser descrito em termos de desvios da média:

$$
\left(y_{t}-\mu\right)=\Phi_{1}\left(y_{t-1}-\mu\right)+\Phi_{2}\left(y_{t-2}-\mu\right)+\ldots+\Phi_{p}\left(y_{t-p}-\mu\right)+\varepsilon_{t}
$$

Essa representação possibilita um VAR(p) se escrito como um VAR(1), o que é bastante útil para a verificação de estacionaridade (PIMENTA JUNIOR, 2000). Assim:

$$
\xi_{t}=F \xi_{t-1}+v_{t}
$$

Em que:

$$
\xi_{t}=\left[\begin{array}{c}
y_{t}-\mu \\
y_{t-1}-\mu \\
y_{t-2}-\mu \\
\cdots \\
y_{t-p+1}-\mu
\end{array}\right]_{(n p \times 1)} \quad v_{t}=\left[\begin{array}{c}
\varepsilon_{t} \\
0 \\
0 \\
\cdots \\
0
\end{array}\right]_{(n p \times 1)}
$$




$$
F=\left[\begin{array}{cccccc}
\Phi_{1} & \Phi_{2} & \Phi_{3} & \ldots & \Phi_{p-1} & \Phi_{p} \\
I_{n} & 0 & 0 & \ldots & 0 & 0 \\
0 & I_{n} & 0 & \ldots & 0 & 0 \\
\cdot & \cdot & . & \ldots & . & \cdot \\
\cdot & \cdot & . & \ldots & . & \cdot \\
\cdot & . & . & \ldots & . & \cdot \\
0 & 0 & 0 & 0 & I_{n} & 0
\end{array}\right]_{(n p \times n p)}
$$

Em que:

$\mathrm{E}\left[v_{t} v_{t}^{\prime}\right]=\{\mathrm{Q}$, para $t=\tau$ e 0 , para $t \neq \tau\}$, com:

$$
Q=\left[\begin{array}{cccccc}
\Omega & 0 & 0 & \ldots & 0 & 0 \\
0 & 0 & 0 & \ldots & 0 & 0 \\
0 & 0 & 0 & \ldots & 0 & 0 \\
. & . & . & \ldots & . & . \\
. & . & . & \ldots & . & . \\
. & . & . & \ldots & . & . \\
0 & 0 & 0 & 0 & 0 & 0
\end{array}\right]_{(n p \times n p)}
$$

A equação $\xi_{t}=F \xi_{t-1}+v_{t}$ implica em

$$
\xi_{t+s}=v_{t+s}+F^{1} v_{t+s-1}+F^{2} v_{t+s-2}+F^{3} v_{t+s-3}+\ldots+F^{s-1} v_{t+1}+F^{s} \xi_{t}
$$

Se os valores de F situam-se dentro de um círculo de raio unitário, o VAR é um processo de covariância estacionário. Os valores de F são as raízes $\lambda$ da equação abaixo:

$\left[I_{n} \lambda^{p}-\Phi_{1} \lambda^{p-1}-\Phi_{2} \lambda^{p-2}-\Phi_{3} \lambda^{p-3}-\ldots-\Phi_{p}\right]=0$

Assim, para a estacionaridade, $|\lambda|<1$, sendo $\lambda$ raiz da equação. 
A identificação da existência de raízes unitárias nos modelos é o primeiro passo para que se verifique a presença de cointegração. A cointegração é uma propriedade que os dados de algumas séries temporais não-estacionárias possuem e que, segundo Maddala (2003), busca identificar as inter-relações entre movimentos de longo prazo em séries temporais econômicas.

\subsubsection{INTEGRAÇÃO DAS SÉRIES DE TEMPO}

Segundo Grôppo (2004), em qualquer análise econométrica, o primeiro passo é verificar a ordem de integração das séries de tempo, pois só será possível estimar um modelo de regressão se as séries forem estacionárias. A falta de integração indica que as variáveis não têm algum tipo de ligação de longo prazo, podendo ter comportamentos que divergem aleatoriamente no tempo (PIMENTA JUNIOR, 2000).

Para verificar a ordem de integração das séries econômicas, ou seja, o número de vezes que uma série necessita ser diferenciada para que ela se torne estacionária, são utilizados os testes de raízes unitárias (GRÔPPO, 2004).

O primeiro teste desenvolvido para testar a presença de raiz unitária foi o de Fuller (1976), complementado por Dickey e Fuller (1979 e 1981). Dickey e Fuller derivaram a distribuição do estimador $\hat{\rho}$ que está presente quando $\rho=1$ e geraram estatísticas para um teste $F$ simples da hipótese de passeio aleatório, isto é da hipótese de que $\beta=0$ e $\rho=1$ (PINDYCK; RUBINFELD, 2004). 
Dessa forma, considera-se o seguinte modelo Dickey-Fuller (GRÔPPO, 2004):

1) $Y_{t}=\rho Y_{t-1}+\varepsilon_{t} \quad$ (modelo sem intercepto)

2) $Y_{t}=\alpha+\rho Y_{t-1}+\varepsilon_{t} \quad$ (modelo com intercepto)

3) $Y_{t}=\alpha+\beta t+\rho Y_{t-1}+\varepsilon_{t} \quad$ (modelo com intercepto e tendência)

Em que $\varepsilon_{t}$ é um ruído branco.

$\varepsilon_{t}$ é considerado um ruído branco se:

a) $E\left(\varepsilon_{t}\right)=0, \forall t$

b) $E\left(\varepsilon_{t}^{2}\right)=\sigma^{2}, \forall t$;

c) $E\left(\varepsilon_{t}, \varepsilon_{t-j}\right)=0, \forall t, \forall j \neq 0$

De acordo com Grôppo (2004), os testes Dickey-Fuller (DF) têm a finalidade de testar a existência da raiz unitária em $Y_{t}$ para os três modelos (equações 1, 2 e 3) sob a hipótese de não existência de auto-correlação nos resíduos. Ao subtrair-se $Y_{t-1}$ dos dois lados da igualdade nos modelos, têm-se:

4) $\Delta Y_{t}=\lambda Y_{t-1}+\varepsilon_{t}$

5) $\Delta Y_{t}=\alpha+\lambda Y_{t-1}+\varepsilon_{t}$

6) $\Delta Y_{t}=\alpha+\beta t+\lambda Y_{t-1}+\varepsilon_{t}$

Os testes Dickey-Fuller (DF) baseiam-se em um processo auto-regressivo de ordem um $\mathrm{AR}(1)$. Entretanto, se o processo auto-regressivo for de ordem $\mathrm{p}$, com $\mathrm{p}>1$, deve-se incluir as 
defasagens das variáveis diferenciadas $\left(\sum_{i=1}^{p-1} \delta_{i} \Delta Y_{t-i}\right)$ nas equações (4), (5) e (6), para preservar a condição de ruído branco (GRÔPPO, 2004). O teste então se torna o de Dickey-Fuller Aumentado (DFA), assumindo a forma:

7) $\Delta Y_{t}=\lambda Y_{t-1}+\sum_{i+1}^{p-1} \delta_{i} \Delta Y_{t-i}+\varepsilon_{t}$

8) $\Delta Y_{t}=\alpha+\lambda Y_{t-1}+\sum_{i+1}^{p-1} \delta_{i} \Delta Y_{t-i}+\varepsilon_{t}$

9) $\Delta Y_{t}=\alpha+\beta t+\lambda Y_{t-1}+\sum_{i+1}^{p-1} \delta_{i} \Delta Y_{t-i}+\varepsilon_{t}$

em que $\Delta Y_{t-1}=\left(Y_{t-1}-Y_{t-2}\right) ; \Delta Y_{t-2}=\left(Y_{t-2}-Y_{t-3}\right)$; etc., isto é, usa-se termos diferenciados defasados (GRÔPPO, 2004).

De acordo com Grôppo (2004), antes de testar a cointegração, é necessário verificar a ordem de integração das variáveis em estudo utilizando o teste de raiz unitária de Dickey-Fuller Aumentado (DFA). As técnicas Dickey-Fuller e Dickey-Fuller Aumentada são as mais utilizadas nos trabalhos que utilizam modelos de auto-regressão de séries temporais. Além dessas, também são utilizadas as técnicas de Durbin-Watson (ENGLE; GRANGER, 1997) e o teste Philips-Perron (1988). 


\subsubsection{TESTE DE CAUSALIDADE PARA VARIÁVEIS COINTEGRADAS}

O conceito de cointegração foi introduzido por Granger (1983), com aprimoramentos nos trabalhos de Granger e Weiss (1983) e Engle e Granger (1987) (PIMENTA JUNIOR, 2000). A cointegração busca identificar se os processos não estacionários apresentam uma relação de equilíbrio de longo prazo, para qual um sistema econômico converge (GRÔPPO, 2004).

De acordo com Engle e Granger (1987), a definição formal de cointegração é: “os componentes do vetor $X_{t}$ são ditos cointegrados de ordem d,b, denotados $X_{t} \sim C I(d, b)$, se (i) todos os componentes de $X_{t}$ são $I(d)$; (ii) existe um vetor $\alpha(\neq 0)$ e então $Z_{t}=\alpha^{\prime} X_{t} \sim I(d-b), b>0$ ". O vetor $\alpha$ é chamado vetor de cointegração. Para o caso de $d=1$ e $b=1$, cointegração significaria que se os componentes de $X_{t}$ são todos $I(1)$, então o erro de equilíbrio seria $I(0)$.

Duas variáveis são ditas co-integradas quando uma combinação linear das duas é estacionária, mesmo que cada uma das variáveis não o seja (PIMENTA JUNIOR, 2000). Uma das formas para se verificar se duas séries são cointegradas é realizar a regressão de uma série sobre a outra, formando uma série residual, e testar essa série de resíduos quanto à presença de raiz unitária. Quando um modelo VAR envolve variáveis $y_{t}, x_{t}, \ldots$, que seguem modelos autoregressivos de séries temporais de ordem $\mathrm{p}$, denominadas $\mathrm{I}(\mathrm{P})$, espera-se que os termos estocásticos tenham a mesma ordem (PIMENTA JUNIOR, 2000).

Para efeitos de exemplificação, considerando duas variáveis com uma equação de regressão, tem-se: 
$y_{t}=\beta_{1}+\beta_{2} x_{t}+\varepsilon_{t}$

Admitindo-se que $y_{t}$ e $x_{t}$ sejam séries temporais I(1) não estacionárias, espera-se que o termo $\varepsilon_{t}$, seja também I(1), afinal:

$\varepsilon_{t}=y_{t}-\beta_{1}-\beta_{2} x_{t}$

Mas, se $\varepsilon_{t}$ é I(1), então:

$\varepsilon_{t}=\varepsilon_{t-1}+v_{t}$

Em que $v_{t}$ é um erro aleatório estacionário não necessariamente não correlacionado serialmente.

Uma forma de se detectar a cointegração é estimar a equação de regressão com o método dos mínimos quadrados; obter resíduos $\varepsilon_{t}$, e finalmente testar se $\varepsilon_{t}$ tem raiz unitária (PIMENTA JUNIOR, 2000). Assim:

$\varepsilon_{t}=\theta_{1} \varepsilon_{t-1}+v_{t}$ $\Delta \varepsilon_{t}=\varepsilon_{t}-\varepsilon_{t-1}=\left(\theta_{1}-1\right) \varepsilon_{t-1}+v_{t}$ $\Delta \varepsilon_{t}=\theta_{1}^{*} \varepsilon_{t-1}+v_{t}$

A hipótese nula a ser testada é $\mathrm{H}_{0}: \theta_{1}^{*}=0$, contra $\mathrm{H}_{1}: \theta_{1}^{*}<0$. Se $\mathrm{H}_{0}$ é rejeitada, então $y_{t}$ e $x_{t}$ são cointegradas.

Segundo Pimenta Junior (2000), a modelagem da auto-correlação possível em $v_{t}$ pode afetar o resultado do teste e por isso é recomendável que se testem modelos alternativos com 
variáveis adicionais na forma $\Delta \varepsilon_{t-j}$ para $\mathrm{j}=1,2,3, \ldots$. Se $\mathrm{H}_{0}$ for rejeitada, mesmo com tais variações, então a cointegração fica ratificada (técnica Dickey-Fuller Aumentado - DFA).

Outros procedimentos podem ser considerados para testar a existência de cointegração entre as variáveis: o procedimento de Johansen e Juselius e o precedimento de Engle e Granger.

Toda e Philips (1993) sugerem que o modelo de correção de erros do tipo Johansen oferece base mais segura para o teste de causalidade com base em VAR (MATOS, 2002). O procedimento sugerido por Johansen (1988) consiste em obter o número de vetores de cointegração estatisticamente significativos. Em um sistema bivariado, o número máximo de valores é sempre um, de modo que a hipótese nula é que não existe vetor de cointegração contra hipótese alternativa de existência e, nesse caso, os resíduos gerados pela equação cointegrante são usados para definir o termo de correção de erros (MATOS, 2002).

\subsubsection{TESTE DE CAUSALIDADE DE GRANGER}

Após ser feito o teste das raízes unitárias, o próximo teste a ser feito é o de causalidade de Granger. O teste de Granger ficou popularizado pela afirmação do econometrista de que o futuro não pode causar o passado nem o presente (CARNEIRO, 1997). Esse teste deve mostrar que uma série temporal provoca outra série, se seus valores defasados são preditores significativos desta outra série, enquanto que a relação inversa não se verifica de forma significativa (PIMENTA JUNIOR, 2000). Exemplificando: se o evento X ocorre depois do evento $\mathrm{Y}$, sabe-se que $\mathrm{X}$ não pode causar $\mathrm{Y}$. Ao mesmo tempo, se $\mathrm{X}$ ocorre antes que $\mathrm{Y}$, isso não significa que $\mathrm{X}$, necessariamente, cause $\mathrm{Y}$. 
De acordo com o conceito de causalidade proposto por Granger (1980), se:

$$
\sigma^{2}\left(X_{t} \mid Z_{t-1}\right) \leq \sigma^{2}\left(X_{t} \mid Z_{t-1}-Y_{t-1}\right)
$$

então diz-se que Y causa X se o conjunto de informações que incluem os dados passados de $\mathrm{Y}, Z_{t-1}$, fornece uma melhor predição de $\mathrm{X}$ que o mesmo conjunto de dados sem $\mathrm{Y}$, $\left(Z_{t-1}-Y_{t-1}\right)$. Se a inequação acima não se verifica, então diz-se que $X$ não causa $Y$ e ainda se:

$\sigma^{2}\left(X_{t} \mid Z_{t-1}\right) \leq \sigma^{2}\left(X_{t} \mid Z_{t-1}-Y_{t-1}\right), \mathrm{e}$

$\sigma^{2}\left(X_{t} \mid Z_{t-1}\right) \leq \sigma^{2}\left(X_{t} \mid Z_{t-1}-Y_{t-1}\right)$

Diz-se que existe feedback entre $\mathrm{X}$ e $\mathrm{Y}$.

De acordo com Pindyck e Rubinfeld (2004), para testar se X causa Y, deve-se seguir o seguinte procedimento: primeiro testa-se a hipótese nula " $\mathrm{X}$ não causa $\mathrm{Y}$ ", com a estimativa de duas regressões:

Regressão irrestrita $-Y=\sum_{i=1}^{m} \alpha_{i} Y_{t-i}+\sum_{i=1}^{m} \beta_{i} Y_{t-i}+\varepsilon_{t}$

Regressão restrita $-Y=\sum_{i=1}^{m} \alpha_{i} Y_{t-i}+\varepsilon_{t}$

e usa-se a soma dos quadrados dos resíduos de cada regressão para calcular a estatística $\mathrm{F}$ e testar se o grupo de coeficientes $\beta_{1}, \beta_{2}, \beta_{3}, \ldots \beta_{m}$ é significativamente diferente de zero. Em caso afirmativo, pode-se rejeitar a hipótese de que "X não causa $Y$ ". Em seguida, testa-se a hipótese nula "Y não causa X" pela estimativa das mesmas regressões mencionadas, contudo trocando X com Y e testando se os valores defasados de $\mathrm{Y}$ são significativamente diferentes de zero. Para concluir que $\mathrm{X}$ causa $\mathrm{Y}$, deve-se rejeitar a hipótese de que "X não causa $\mathrm{Y}$ " e 
aceitar a hipótese "Y não causa X". Contudo, a fraqueza desse teste de causalidade é que uma terceira variável Z pode causar Y e ser contemporaneamente correlacionada a X.

O número de defasagens $m$ nessas regressões é arbitrário e é necessária a realização de testes para alguns valores diferentes de $m$, e garantir que os resultados não sejam sensíveis à escolha de $m$ (PINDYCK; RUBINFELD, 2004). Assim, um passo importante no uso da Causalidade de Granger é a determinação do tamanho da defasagem das variáveis a serem utilizadas (PIMENTA JUNIOR, 2000).

\subsubsection{A ESCOLHA DO NÚMERO DE DEFASAGENS}

Um importante ponto na análise da relação de causalidade entre duas variáveis refere-se à escolha do número adequado de defasagens a ser utilizado nas regressões. Gujarati (1995) alerta para o fato de que o teste de causalidade é muito sensível ao número de defasagens escolhido.

Em modelos de séries temporais pode haver um período de tempo substancial entre o período em que são tomadas decisões de política econômica e o impacto dessas mudanças na variável de política econômica. Se o período entre a decisão e resposta é suficientemente longo, variáveis explanatórias defasadas deveriam ser incluídas explicitamente no modelo (PINDYCK; RUBINFELD, 2004).

Davidson e MacKinnon (1993), corroborado por Mills (1993) sugerem que se procure identificar primeiro o número de defasagens e, então, efetuar os testes de causalidade. 
Segundo Campbell e Perron (1991), para determinar o número de defasagens, estimam-se um número grande de defasagens que vão sendo eliminadas uma a uma caso o coeficiente da última apresente-se não significativo. Davidson e MacKinnon (1993) "argumentam que a escolha de um número grande de defasagens seria preferível, uma vez que dessa forma o analista pode verificar como a exclusão de algumas defasagens afeta o resultado das estimações".

De acordo com Pindyck e Rubinfeld (2004), a base da defasagem distribuída é que, de modo geral, as mudanças econômicas podem ser distribuídas ao longo de uma série de períodos no tempo. Assim:

[...] Se o número de termos da defasagem distribuída é pequeno, a equação pode ser estimada pelo método dos mínimos quadrados ordinários, contudo, quando há muitos termos e pouco se sabe sobre a forma da defasagem, a estimação direta gasta um grande número de graus de liberdade e tende a levar a estimativas de parâmetros imprecisas por causa da multicolinearidade. (PINDYCK; RUBINFELD, 2004, p. 264) [...] A multicolinearidade ocorre quando duas ou mais variáveis são altamente correlacionadas entre si. Nesse caso, será possível obter estimativas de mínimos quadrados dos coeficientes da regressão, mas a interpretação desses coeficientes será bem difícil. (PINDYCK; RUBINFELD, 2004, p.100)

Segundo Pindyck e Rubinfeld (2004), podem ser utilizadas as abordagens do $\mathrm{R}^{2}$ ajustado, o critério de informação Akaike e o critério de Schwartz.

A abordagem do $\mathrm{R}^{2}$ ajustado serve para determinar quantas defasagens devem ser adicionadas. Essa abordagem apresenta limitação, pois o uso do $\mathrm{R}^{2}$ ordinário como medida da qualidade do ajustamento da equação $\mathrm{R}^{2}$ não leva em conta o número dos graus de liberdade. $\mathrm{O} \mathrm{R}^{2}$ ajustado mede a percentagem da variância na variável dependente explicada pelas variáveis explanatórias (PINDICK; RUBINFELD, 2004): 
$\bar{R}^{2}=1-\frac{\hat{\operatorname{Var}}(\varepsilon)}{\hat{\operatorname{Var}}(y)}$

As variâncias amostrais de $\hat{\varepsilon}$ e y são calculadas da seguinte maneira:

$\hat{\operatorname{Var}}(\varepsilon)=s^{2}=\frac{\sum \hat{\varepsilon}_{i}^{2}}{N-k} \quad$ e $\quad \hat{\operatorname{Var}}(y)=\frac{\sum\left(Y_{i}-\bar{Y}\right)^{2}}{N-1}$

Em que k é o número de variáveis explanatórias.

Considerando que: $\quad R^{2}=1-\frac{s^{2}}{\operatorname{Var}(y)} \frac{N-k}{N-1}$, isso permite derivar a fórmula para ter a relação entre $\mathrm{R}^{2}$ e $\bar{R}^{2}$. Assim:

$\bar{R}^{2}=1-\left(1-R^{2}\right) \frac{N-1}{N-k}$

Em que N é o número de observações e k é o número de variáveis dependentes.

Assim, uma possível abordagem para a seleção do número de defasagens em um modelo de defasagem distribuída é simplesmente acrescentar defasagens adicionais até que o $\mathrm{R}^{2}$ ajustado pare de aumentar (PINDYCK; RUBINFELD, 2004). Thornton e Batten (1985) sugerem que o critério FPE de Akaike (FPE), conhecido como Critério de Informação de Akaike (AIC), é melhor que os demais critérios de seleção existentes.

O Critério de Informação Akaike pode ser demonstrado da seguinte forma (GRÔPPO, 2004): 
$A I C=\ln \hat{\sigma}^{2}+\left(\frac{2}{T}\right)$ (número de parâmetros)

Em que $\sigma^{2}$ é a soma dos quadrados dos resíduos estimados do processo auto-regressivo de ordem p, e T é o número de observações da amostra (GRÔPPO, 2004).

Pindyck e Rubinfeld (2004) demonstram o critério Akaike da seguinte forma:

$$
A I C=\log \left(\frac{\sum \hat{\varepsilon}_{i}^{2}}{N}\right)+\frac{2 k}{N}
$$

Em que $\sum \hat{\varepsilon}_{i}^{2}$ é a soma de quadrados dos resíduos.

$\mathrm{O}$ critério de informação de Akaike difere do $\mathrm{R}^{2}$ ajustado porque penaliza bem mais a adição de variáveis do lado direito da equação, o que reduz o número de graus de liberdade.

Outro teste conhecido para escolha do tamanho ótimo das defasagens deve-se a Schwarz (1978) e consiste em minimizar a função de SC (Schwarz Criterion):

$$
S C=\ln \vartheta^{2}+m \ln n
$$

Em que $\vartheta^{2}$ é a estimativa da máxima verossimilhança de $\sigma^{2}$ (= soma do quadrado dos resíduos dividida por $\mathrm{n}$ ), m é o número de defasagens e n é o número de observações. Pindyck e Rubinfeld (2004) demonstram o critério Schwarz da seguinte forma:

$$
S C=\log \left(\frac{\sum \varepsilon_{i}^{2}}{N}\right)+\frac{k \log N}{N}
$$


Essa fórmula penaliza a adição de variáveis do lado direito mais fortemente do que faz o $\mathrm{R}^{2}$ ajustado.

Com o desenvolvimento de modelos de regressão vetorial, vários modelos foram criados, sempre baseados na minimização das funções do tipo (PIMENTA JUNIOR, 2000 e KOREISHA; PUKKILA, 1996,):

$\delta(p)=N \log \left|\sum_{p}\right|+\mathrm{p} \mathrm{g}(\mathrm{N}) \quad \mathrm{p}=1,2,3, \ldots, \mathrm{p}^{*}$,

Em que $\sum_{p}$ é uma representação da matriz covariância residual associada ao modelo VAR(p) ajustado; $g(\mathrm{~N})$ é uma função de penalidade; $\mathrm{p}^{*}$ é um limite da ordem da autoregressão pré-determinado. De acordo com o modelo acima, foram desenvolvidos diversos critérios para escolha das defasagens (PIMENTA JUNIOR, 2000). A seguir o quadro 5.2 apresenta um resumo dos critérios:

\begin{tabular}{|c|c|c|}
\hline CRITÉRIO & CONDICCÃO & OBSERVAÇÃO \\
\hline AKAIKE (AIC) & $\mathrm{g}(\mathrm{N})=2 \mathrm{~K}^{2}$ & \\
\hline $\begin{array}{l}\text { BIC - Bayesian } \\
\text { Information } \\
\text { Criterion }\end{array}$ & $g(N)=K^{2} \log N$ & Rissanen (1978) e Schwarz (1978) \\
\hline HQ & $g(N)=c \log \log N$ & $\begin{array}{l}\text { Hannan e Quinn (1979) } \\
\text { Quinn }(1980) \\
\text { Quando } c=2+\varepsilon, \varepsilon>0 \text {, o critério } \\
\text { mostra-se fortemente consistente }\end{array}$ \\
\hline HQP & $\mathrm{g}(\mathrm{N})=[\mathrm{N} /(\mathrm{N}-0,5 \mathrm{~K}(\mathrm{p}+1))]\left[\mathrm{K}^{2}+\mathrm{K}(\log \mathrm{N}-1)\right]$ & Pukkila e Krishnaiah (1988) \\
\hline $\begin{array}{l}\text { RWNAR - Residual } \\
\text { White Noise Auto } \\
\text { Regressive }\end{array}$ & $\begin{array}{l}\text { Modelo baseado na verificação do } \\
\text { comportamento dos resíduos como ruídos } \\
\text { brancos }\end{array}$ & Pukkila e Krishnaiah (1988) \\
\hline
\end{tabular}

Quadro 5.3 - Critérios para escolha de defasagens 


\subsubsection{O MÉTODO DE CORREÇÃO DE ERROS}

Métodos de correção de erros têm sido muito usados em economia, com as primeiras versões nos trabalhos de Philips e Sargan (ENGLE; GRANGER, 1987). De acordo com Carneiro (1997), uma versão mais moderna do teste de Causalidade de Granger permite que sejam identificadas possíveis relações de causalidade entre duas variáveis originárias de uma mesma tendência de longo prazo, por meio do método de correção de erros propostos por Engle e Granger (1987). O modelo Engle e Granger incorpora um possível efeito de longo prazo em uma análise de curto prazo (CARNEIRO, 1997, p. 8):

O método baseado no mecanismo de correção de erros (Error Correction Mechanism) examina se valores defasados de uma variável $\mathrm{X}$ podem ajudar a explicar mudanças nos valores correntes de uma outra variável $\mathrm{Y}$, mesmo se mudanças passadas em Y não sejam relevantes, assumindo-se, no entanto, que ambas as variáveis sejam estacionárias.

Segundo Pimenta Junior (2000) a presença de cointegração entre as variáveis de um modelo VAR possibilita a representação melhor das séries temporais. Se duas variáveis são cointegradas, elas seguem um modelo de correção de erro que pode ser bem especificado, que acaba por se transformar em uma representação mais apurada.

Exemplificando, em um conjunto de equações de um modelo VAR(1) tem-se (PIMENTA JUNIOR, 2000):

$$
\begin{aligned}
& x_{t}=\theta_{0}+\theta_{1} x_{t-1}+\phi_{1} y_{t-1}+e_{t} \\
& y_{t}=\delta_{0}+\delta_{1} x_{t-1}+\alpha_{1} y_{t-1}+u_{t}
\end{aligned}
$$

Subtraindo-se $x_{t-1}$ da primeira equação e $y_{t-1}$ da segunda, obtém-se as equações:

$$
\Delta x_{t}=x_{t}-x_{t-1}=\theta_{0}+\left(\theta_{1}-1\right) x_{t-1}+\phi_{1} y_{t-1}+e_{t}
$$




$$
\Delta y_{t}=y_{t}-y_{t-1}=\delta_{0}+\delta_{1} x_{t-1}+\left(\alpha_{1}-1\right) y_{t-1}+u_{t}
$$

Se $x_{t}$ e $y_{t}$ são ambos I(1) e cointegrados, então os coeficientes das equações acima satisfazem a seguinte restrição: $\theta_{1}=1+\left[\phi_{1} \delta_{1} /\left(\alpha_{1}-1\right)\right]$, que substituída no sistema, gera:

$$
\Delta x_{t}=\theta_{0}+\left[\phi_{1} \delta_{1} /\left(\alpha_{1}-1\right)\right] x_{t-1}+\phi_{1} y_{t-1}+e_{t}
$$

Desse modo, o sistema pode ser escrito como:

$$
\begin{aligned}
& \left.\Delta x_{t}=\theta_{0}+\left[\phi_{1} \delta_{1} /\left(\alpha_{1}-1\right)\right] x_{t-1}-\left[\left(1-\alpha_{1}\right) / \delta_{1}\right] y_{t-1}\right]+e_{t} \\
& \Delta y_{t}=\delta_{0}+\left[x_{t-1}-\left[\left(1-\alpha_{1}\right) / \delta_{1}\right] y_{t-1}\right] \delta_{1}+u_{t}
\end{aligned}
$$

\section{Escrevendo:}

$$
\begin{aligned}
& \beta_{2}=\left(1-\alpha_{1}\right) / \delta_{1} \\
& \gamma_{1}=\phi_{1} \delta_{1} /\left(\alpha_{1}-1\right) \\
& \gamma_{2}=\delta_{1} \\
& \theta_{0}^{*}=\theta_{0}+\gamma_{1} \beta_{1} \\
& \delta_{0}^{*}=\delta_{0}+\gamma_{2} \beta_{1}
\end{aligned}
$$

Assim, pode-se representar o sistema na forma do modelo de correção de erro:

$$
\begin{aligned}
& \Delta x_{t}=\theta_{0}^{*}+\gamma_{1}\left(x_{t-1}-\beta_{1}-\beta_{2} y_{t-1}\right)+e_{t} \\
& \Delta y_{t}=\delta_{0}^{*}+\gamma_{2}\left(x_{t-1}-\beta_{1}-\beta_{2} y_{t-1}\right)+u_{t}
\end{aligned}
$$

No caso, as variações de $\mathrm{x}$ e y entre os períodos $\mathrm{t}-1$ e $\mathrm{t}$ dependem, nos dois casos, da mesma grandeza: 
$\varepsilon_{t}=x_{t-1}-\beta_{1}-\beta_{2} y_{t-1}$

Assim, representando na forma mais condensada, tem-se:

$$
\begin{aligned}
& \Delta x_{t}=\theta_{0}^{*}+\gamma_{1} \varepsilon_{t-1}+e_{t} \\
& \Delta y_{t}=\delta_{0}^{*}+\gamma_{2} \varepsilon_{t-1}+u_{t}
\end{aligned}
$$

Essa grandeza $\left(\varepsilon_{t-1}\right)$ representa o desvio $\varepsilon$, no período $\mathrm{t}-1$, em relação a trajetória de equilíbrio de longo prazo $x=\beta_{1}+\beta_{2} y$. 


\section{APRESENTAÇÃO E ANÁLISE DOS RESULTADOS}

A avaliação da existência de interdependência entre as variáveis econômicas foi feita por meio de um modelo de auto-regressão vetorial (VAR). Segundo Pimenta Jr. (2000, p. 108):

[...] esse tipo de modelagem é indicado para o estudo do comportamento e previsão dos valores de duas ou mais variáveis econômicas, apresentadas sobre a forma de séries temporais, sendo portanto, o modelo VAR adotado classificado como um modelo de séries temporais multivariado.

O primeiro passo para a avaliação da interdependência é o teste de estacionaridade dos dados. Em caso de não estacionaridade de alguma das séries temporais, é necessário utilizar uma técnica de alisamento. O passo seguinte é o teste de causalidade de Granger. Através desse teste verifica-se se há indícios de causalidade entre as séries temporais. A análise das Decomposições da Variância, feitas após o teste de Causalidade de Granger, serve para avaliar se a variância de determinado indicador é explicada pela variância de outros indicadores. A avaliação é concluída com a análise das Funções de Resposta a Impulso.

\subsection{TESTE DE ESTACIONARIDADE DOS DADOS}

A utilização adequada do modelo de auto-regressão vetorial requer que as séries temporais sejam estacionárias, ou seja, que a média, a variância e a função de auto-covariância não se alterem ao longo do tempo. Dessa forma, o primeiro teste realizado foi o teste Dickey Fuller Aumentado (DFA) para verificação da estacionaridade nas séries temporais. Através do teste DFA é possível verificar a existência de raízes unitárias na representação univariada das variáveis. 
As tabelas 6.3 a 6.10 mostram que a hipótese nula de não-estacionaridade não é rejeitada para todas as séries. Isso significa que algumas séries precisaram sofrer processo de ajuste para a obtenção da estacionaridade. A técnica de ajuste utilizada foi a diferenciação.

As variáveis Produto Interno Bruto (DIFPIB) e Investimento Estrangeiro Direto (DIFIED) sofreram diferenciação de primeira ordem. Após a diferenciação, as séries temporais dessas variáveis apresentaram estacionaridade ao nível de $1 \%$ com as variáveis em nível. Para as variáveis Poupança (POUPANCA) e Coeficiente de Abertura (COEFABERT) a hipótese nula de não-estacionaridade foi rejeitada ao nível de $1 \%$, com a variável Poupança em nível e a variável Coeficiente de Abertura com uma defasagem. Para as demais variáveis, a hipótese nula de não-estacionaridade foi rejeitada ao nível de 5\%, com a variável Investimento Interno (INVESTIMENTO) em nível, a variável Royalties e Licenças (ROYALTIES) com uma defasagem e as variáveis Produtividade (PRODUTIVIDADE) e Exportações (EXPORTACAO) com duas defasagens.

Todas as variáveis serão testadas ao nível de significância de 5\%. Assim, o valor crítico para rejeição da hipótese nula de raízes unitárias ao nível de 5\% é -2,918778, definido por MacKinnon, conforme apresenta a tabela 6.1. As séries com valores da estatística t inferiores ao valor crítico ao nível de 5\% (-2,918778) são consideradas estacionárias. A exemplo, para o PIB, o valor do t estatístico é $-4,2444$. Nesse caso, a hipótese nula da não-estacionaridade é rejeitada aos níveis de significância de 1\%, 5\% e $10 \%$.

A tabela 6.1 apresenta os valores críticos em cada nível de significância. A tabela 6.2 apresenta as variáveis testadas, com as respectivas defasagens e o nível de significância aceito. 


\begin{tabular}{lccc}
\hline Augmented Dickey-Fuller test statistic & & \\
\hline Test critical values: & $1 \%$ level & Valor Crítico & $-3,562669$ \\
& $5 \%$ level & Valor Crítico & $-2,918778$ \\
& $10 \%$ level & Valor Crítico & $-2,597285$ \\
& & \\
\end{tabular}

Tabela 6.1 - Teste DFA - Valores críticos para verificação de raízes unitárias

\begin{tabular}{|c|c|c|c|c|c|c|c|}
\hline Variável & Coeficiente & Erro Padrão & Estatística-t & Probab. & $1 \%$ & $5 \%$ & $10 \%$ \\
\hline DIFPIB(-1) & $-1,974759$ & 0,465262 & $-4,2444$ & 0,0001 & * & * & * \\
\hline $\mathrm{D}(\operatorname{DIFPIB}(-1))$ & 0,46026 & 0,355241 & 1,295625 & 0,2006 & & & \\
\hline $\mathrm{D}(\mathrm{DIFPIB}(-2))$ & $-0,009139$ & 0,237194 & $-0,03853$ & 0,9694 & & & \\
\hline D(DIFPIB(-3)) & $-0,381478$ & 0,119593 & $-3,1898$ & 0,0024 & & * & * \\
\hline PRODUTIVIDADE(-1) & $-0,038599$ & 0,028586 & $-1,3503$ & 0,1835 & & & \\
\hline D(PRODUTIVIDADE(-1)) & $-0,069656$ & 0,130493 & $-0,53379$ & 0,5961 & & & \\
\hline D(PRODUTIVIDADE(-2)) & $-0,456173$ & 0,129912 & $-3,51141$ & 0,001 & & * & * \\
\hline D(PRODUTIVIDADE(-3)) & $-0,16107$ & 0,130549 & $-1,23379$ & 0,2235 & & & \\
\hline D(PRODUTIVIDADE(-4)) & 0,396925 & 0,135584 & 2,927523 & 0,0053 & & & \\
\hline ROYALTIES(-1) & $-0,052258$ & 0,053781 & $-0,97168$ & 0,3352 & & & \\
\hline D(ROYALTIES(-1)) & $-0,431637$ & 0,125068 & $-3,45121$ & 0,001 & & * & * \\
\hline INVESTIMENTO(-1) & $-0,843404$ & 0,251996 & $-3,3469$ & 0,0015 & & * & * \\
\hline D(INVESTIMENTO(-1)) & $-0,397046$ & 0,201162 & $-1,97376$ & 0,0535 & & & \\
\hline D(INVESTIMENTO(-2)) & $-0,39472$ & 0,154227 & $-2,55934$ & 0,0133 & & & \\
\hline D(INVESTIMENTO(-3)) & $-0,430879$ & 0,098892 & $-4,35707$ & 0,0001 & * & * & * \\
\hline POUPANCA(-1) & $-0,814713$ & 0,124243 & $-6,55743$ & 0 & * & * & * \\
\hline DIFIED(-1) & $-1,766325$ & 0,209999 & $-8,41111$ & 0 & * & * & * \\
\hline $\mathrm{D}(\mathrm{DIFIED}(-1))$ & 0,286657 & 0,127254 & 2,252633 & 0,0281 & & & \\
\hline EXPORTACAO(-1) & 0,104217 & 0,04947 & 2,106663 & 0,0399 & & & \\
\hline D(EXPORTACAO(-1)) & $-0,253468$ & 0,156914 & $-1,61533$ & 0,1122 & & & \\
\hline D(EXPORTACAO(-2)) & $-0,494798$ & 0,152996 & $-3,23407$ & 0,0021 & & * & * \\
\hline D(EXPORTACAO(-3)) & $-0,156074$ & 0,147772 & $-1,05619$ & 0,2957 & & & \\
\hline D(EXPORTACAO(-4)) & 0,468512 & 0,14248 & 3,288268 & 0,0018 & & & \\
\hline COEFABERT(-1) & $-0,29507$ & 0,177157 & $-1,66558$ & 0,1015 & & & \\
\hline D(COEFABERT(-1)) & $-0,651503$ & 0,156378 & $-4,16621$ & 0,0001 & * & * & * \\
\hline $\mathrm{D}(\mathrm{COEFABERT}(-2))$ & $-0,697263$ & 0,124994 & $-5,57837$ & 0 & * & * & * \\
\hline $\mathrm{D}(\mathrm{COEFABERT}(-3))$ & $-0,687219$ & 0,095197 & $-7,21892$ & 0 & * & * & * \\
\hline
\end{tabular}

Tabela 6.2 - Estatística t das variáveis para verificação da hipótese nula

Os resultados do Teste DFA para as variáveis são apresentados a seguir nas tabelas 6.3 a 6.10 . 
Variável Dependente: D(DIFPIB)

Método: Mínimos Quadrados

Amostra (ajustada): 664

Observações Incluídas: 59 após ajustes

$\begin{array}{lrcrr}\text { Variável } & \text { Coeficiente } & \text { Erro Padrão } & \text { Estatística-t } & \text { Probabilidade } \\ & & & & \\ \text { DIFPIB(-1) } & -1,974759 & 0,465262 & -4,244399 & 0,0001 \\ \text { D(DIFPIB(-1)) } & 0,460260 & 0,355241 & 1,295625 & 0,2006 \\ \text { D(DIFPIB(-2)) } & -0,009139 & 0,237194 & -0,038528 & 0,9694 \\ \text { D(DIFPIB(-3)) } & -0,381478 & 0,119593 & -3,189797 & 0,0024 \\ \text { C } & 3367258, & \text { 3984090, } & 0,845176 & 0,4017 \\ & & & \\ \text { red } & 0,907251 & \text { Mean dependent var } & & 2705005, \\ \text { red R-squared } & 0,900381 & \text { S,D, dependent var } & & 96032295 \\ \text { regression } & 30310230 & \text { Akaike info criterion } & & 37,37281 \\ \text { squared resid } & 4,96 \mathrm{E}+16 & \text { Schwarz criterion } & & 37,54887 \\ \text { elihood } & -1097,498 & \text { F-statistic } & & 132,0540 \\ \text {-Watson stat } & 2,154983 & \text { Prob(F-statistic) } & & 0,000000 \\ & & & \end{array}$

Tabela 6.3 - Resultado do Teste DFA para PIB

Variável Dependente: D(PRODUTIVIDADE)

Método: Mínimos Quadrados

Amostra (ajustada): 1364

Observações Incluídas: 52 após ajustes

\begin{tabular}{|c|c|c|c|c|}
\hline Variável & Coeficiente & Erro Padrão & \multicolumn{2}{|c|}{ Estatística-t Probabilidade } \\
\hline PRODUTIVIDADE(-1) & $-0,038599$ & 0,028586 & $-1,350297$ & 0,1835 \\
\hline D(PRODUTIVIDADE(-1)) & $-0,069656$ & 0,130493 & $-0,533790$ & 0,5961 \\
\hline D(PRODUTIVIDADE(-2)) & $-0,456173$ & 0,129912 & $-3,511406$ & 0,0010 \\
\hline D(PRODUTIVIDADE(-3)) & $-0,161070$ & 0,130549 & $-1,233787$ & 0,2235 \\
\hline D(PRODUTIVIDADE(-4)) & 0,396925 & 0,135584 & 2,927523 & 0,0053 \\
\hline $\mathrm{C}$ & 7,034416 & 4,249713 & 1,655269 & 0,1047 \\
\hline uared & 0,680270 & Mean dependent val & & 1,300962 \\
\hline sted R-squared & 0,645517 & S,D, dependent var & & 7,153431 \\
\hline of regression & 4,259044 & Akaike info criterion & & 5,844133 \\
\hline squared resid & 834,4149 & Schwarz criterion & & 6,069277 \\
\hline likelihood & $-145,9475$ & F-statistic & & 19,57430 \\
\hline in-Watson stat & 1,799187 & Prob(F-statistic) & & 0,000000 \\
\hline
\end{tabular}

Tabela 6.4 - Resultado do Teste DFA para Produtividade 
Variável Dependente: D(ROYALTIES)

Método: Mínimos Quadrados

Amostra (ajustada): 364

Observações Incluídas: 62 após ajustes

$\begin{array}{ccccr}\text { Variável } & \text { Coeficiente } & \text { Erro Padrão } & \text { Estatística-t } & \text { Probabilidade } \\ \text { ROYALTIES(-1) } & -0,052258 & 0,053781 & -0,971680 & 0,3352 \\ \text { D(ROYALTIES(-1)) } & -0,431637 & 0,125068 & -3,451211 & 0,0010 \\ \text { C } & -17,97109 & 11,70362 & -1,535515 & 0,1300\end{array}$

R-squared

0,200577 Mean dependent var

$-6,733758$

Adjusted R-squared

0,173478 S,D, dependent var

55,80667

$\mathrm{S}, \mathrm{E}$, of regression

50,73566 Akaike info criterion

10,73831

Sum squared resid

151872,3 Schwarz criterion

10,84124

Log likelihood

$-329,8877$

F-statistic

7,401624

Durbin-Watson stat

1,931714

Prob(F-statistic)

0,001355

Tabela 6.5 - Resultado do Teste DFA para Royalties e Licenças

\section{Variável Dependente: D(INVESTIMENTO)}

Método: Mínimos Quadrados

Amostra (ajustada): 664

Observações Incluídas: 59 após ajustes

Variável Coeficiente Erro Padrão Estatística-t Probabilidade

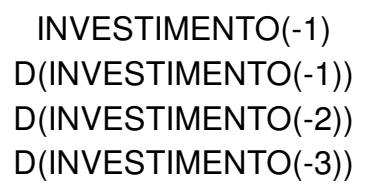

C

R-squared

Adjusted R-squared

$\mathrm{S}, \mathrm{E}$, of regression

Sum squared resid

Log likelihood

Durbin-Watson stat

$\begin{array}{rl}-0,843404 & 0,251996 \\ -0,397046 & 0,201162 \\ -0,394720 & 0,154227 \\ -0,430879 & 0,098892 \\ 0,176384 & 0,052318 \\ & \\ 0,756820 & \text { Mean dependent var } \\ 0,738806 & \text { S,D, dependent var } \\ 0,019069 & \text { Akaike info criterion } \\ 0,019636 & \text { Schwarz criterion } \\ 152,5165 & \text { F-statistic } \\ 2,004171 & \text { Prob(F-statistic) }\end{array}$

$-3,346898$

0,0015

$-1,973759 \quad 0,0535$

$-2,559340 \quad 0,0133$

$-4,357070 \quad 0,0001$

$3,371393 \quad 0,0014$

$-9,32 \mathrm{E}-05$

0,037312

$-5,000561$

$-4,824498$

42,01436

0,000000

Tabela 6.6 - Resultado do Teste DFA para Investimento Interno 
Variável Dependente: D(POUPANCA)

Método: Mínimos Quadrados

Amostra (ajustada): 364

Observações Incluídas: 62 após ajustes

$\begin{array}{crrrr}\text { Variável } & \text { Coeficiente } & \text { Erro Padrão } & \text { Estatística-t } & \text { Probabilidade } \\ \text { POUPANCA(-1) } & -0,814713 & 0,124243 & -6,557427 & 0,0000 \\ \text { C } & 0,151899 & 0,023772 & 6,389786 & 0,0000\end{array}$

R-squared

0,417475 Mean dependent var

$-0,000966$

Adjusted R-squared

0,407766 S,D, dependent var

0,047638

$\mathrm{S}, \mathrm{E}$, of regression

0,036661 Akaike info criterion

$-3,742499$

Sum squared resid

0,080640 Schwarz criterion

$-3,673882$

Log likelihood

118,0175 F-statistic

42,99984

Durbin-Watson stat

1,944105 Prob(F-statistic)

0,000000

Tabela 6.7 - Resultado do Teste DFA para Poupança

Variável Dependente: D(DIFIED)

Método: Mínimos Quadrados

Amostra (ajustada): 464

Observações Incluídas: 61 após ajustes

$\begin{array}{crrrr}\text { Variável } & \text { Coeficiente } & \text { Erro Padrão } & \text { Estatística-t } & \text { Probabilidade } \\ & & & & \\ \text { DIFIED(-1) } & -1,766325 & 0,209999 & -8,411105 & 0,0000 \\ \text { D(DIFIED(-1)) } & 0,286657 & 0,127254 & 2,252633 & 0,0281 \\ \text { C } & 96,97580 & 213,1607 & 0,454942 & 0,6508\end{array}$

R-squared

0,711785 Mean dependent var

3,906402

Adjusted R-squared

0,701846

S,D, dependent var

3042,506

$\mathrm{S}, \mathrm{E}$, of regression

1661,313

Akaike info criterion

17,71653

Sum squared resid

$1,60 \mathrm{E}+08$ Schwarz criterion

17,82035

Log likelihood

$-537,3543$ F-statistic

71,61931

Durbin-Watson stat

2,141158 Prob(F-statistic)

0,000000

Tabela 6.8 - Resultado do Teste DFA para Investimento Estrangeiro Direto 
Variável Dependente: D(EXPORTACAO)

Método: Mínimos Quadrados

Amostra (ajustada): 664

Observações Incluídas: 59 após ajustes

\begin{tabular}{|c|c|c|c|c|}
\hline Variável & Coeficiente & Erro Padrão & Estatística-t & Probabilidade \\
\hline EXPORTACAO(-1) & 0,104217 & 0,049470 & 2,106663 & 0,0399 \\
\hline $\mathrm{D}(\mathrm{EXPORTACAO}(-1))$ & $-0,253468$ & 0,156914 & $-1,615330$ & 0,1122 \\
\hline $\mathrm{D}(\mathrm{EXPORTACAO}(-2))$ & $-0,494798$ & 0,152996 & $-3,234066$ & 0,0021 \\
\hline $\mathrm{D}(\mathrm{EXPORTACAO}(-3))$ & $-0,156074$ & 0,147772 & $-1,056186$ & 0,2957 \\
\hline $\mathrm{D}(\mathrm{EXPORTACAO}(-4))$ & 0,468512 & 0,142480 & 3,288268 & 0,0018 \\
\hline $\mathrm{C}$ & $-889,6936$ & 584,9886 & $-1,520873$ & 0,1342 \\
\hline uared & 0,618078 & Mean dependent var & & 403,0066 \\
\hline sted R-squared & 0,582047 & S,D, dependent var & & 1841,786 \\
\hline of regression & 1190,701 & Akaike info criterion & & 17,09862 \\
\hline squared resid & 75141780 & Schwarz criterion & & 17,30989 \\
\hline ikelihood & $-498,4092$ & F-statistic & & 17,15434 \\
\hline in-Watson stat & 1,955902 & Prob(F-statistic) & & 0,000000 \\
\hline
\end{tabular}

Tabela 6.9 - Resultado do Teste DFA para Exportação

Variável Dependente: D(COEFABERT)

Método: Mínimos Quadrados

Amostra (ajustada): 564

Observações Incluídas: 60 após ajustes

\begin{tabular}{lrcrr}
\multicolumn{1}{c}{ Variável } & Coeficiente & Erro Padrão & Estatística-t & Probabilidade \\
& & & & \\
COEFABERT(-1) & $-0,295070$ & 0,177157 & $-1,665579$ & 0,1015 \\
D(COEFABERT(-1)) & $-0,651503$ & 0,156378 & $-4,166207$ & 0,0001 \\
D(COEFABERT(-2)) & $-0,697263$ & 0,124994 & $-5,578367$ & 0,0000 \\
D(COEFABERT(-3)) & $-0,687219$ & 0,095197 & $-7,218923$ & 0,0000 \\
C & 0,064835 & 0,036200 & 1,791030 & 0,0788 \\
& & & \\
quared & 0,727879 & Mean dependent var & & 0,002760 \\
usted R-squared & 0,708089 & S,D, dependent var & & 0,137891 \\
of regression & 0,074501 & Akaike info criterion & & $-2,276361$ \\
squared resid & 0,305269 & Schwarz criterion & & $-2,101833$ \\
likelihood & 73,29084 & F-statistic & 3,77905 \\
bin-Watson stat & 1,617174 & Prob(F-statistic) & & 0,000000 \\
& & & \\
\hline
\end{tabular}

Tabela 6.10 - Resultado do Teste DFA para Coeficiente de Abertura 


\subsection{TESTE F (ANOVA)}

O próximo teste é o teste $\mathrm{F}$, para avaliar o valor crítico para rejeição da hipótese nula de nãocausalidade. Segundo Matos (2000), o teste F tem por finalidade testar o efeito conjunto das variáveis explicativas sobre a dependente, o que significa verificar se, pelo menos, uma das variáveis explicativas do modelo exerce alguma influencia sobre a variável dependente. Pindyck e Rubinfeld (2004) ainda consideram que a distribuição F pode ser útil para testar hipóteses no contexto de um modelo de regressão múltipla. De acordo com a tabela 6.11, temse que o F crítico, para rejeição da hipótese é nula, é 2,028144.

\begin{tabular}{|c|c|c|c|c|c|c|}
\hline ANOVA & & & & & & \\
\hline Grupo & Contagem & Soma & Média & Variância & & \\
\hline DIFPIB & 63 & 156842847,8 & 2489569,013 & $3,51438 \mathrm{E}+15$ & & \\
\hline PRODUTIVIDADE & 57 & 7977,656667 & 139,9588889 & 597,0011297 & & \\
\hline ROYALTIES & 64 & $-11824,579$ & $-184,7590469$ & 15969,32952 & & \\
\hline INVESTIMENTO & 63 & 13,0524 & 0,207180952 & 0,00067692 & & \\
\hline POUPANCA & 63 & 11,819 & 0,187603175 & 0,001404369 & & \\
\hline DIFIED & 63 & 3375,153107 & 53,57385884 & 3262879,482 & & \\
\hline EXPORTACÃO & 64 & 888863,44 & 13888,49125 & 35097304,78 & & \\
\hline COEFABERT & 64 & 12,6685 & 0,197945313 & 0,01023615 & & \\
\hline Fonte da variação & $S Q$ & $g l$ & $M Q$ & $F$ & valor-P & F crítico \\
\hline Entre grupos & $3,40824 E+14$ & 7 & $4,86892 E+13$ & 0,110163839 & 0,9976960 & 2,028144 \\
\hline Dentro dos grupos & $2,17892 E+17$ & 493 & $4,41971 \mathrm{E}+14$ & & & \\
\hline Total & $2,18232 E+17$ & 500 & & & & \\
\hline
\end{tabular}

Tabela 6.11 - Resultado do Teste F (ANOVA)

\subsection{TESTE DE CAUSALIDADE DE GRANGER}

O teste de Causalidade de Granger verifica a relação de causalidade entre as séries temporais. Este teste avalia se uma série temporal provoca outra, se seus valores defasados são preditores significativos da outra série, e se a relação de causalidade se confirma de forma significativa. Os resultados do Teste de Causalidade de Granger revelaram que foi possível aceitar a 
hipótese nula da existência de vetores nulos de cointegração entre as séries, para a maioria dos casos, ao nível de 5\%.

\begin{tabular}{|c|c|c|c|}
\hline Hipótese Nula & Obs & Estatística $\mathbf{F}$ & Probabilidade \\
\hline PRODUTIVIDADE does not Granger Cause DIFPIB & 55 & 1,7018 & $19,27 \%$ \\
\hline DIFPIB does not Granger Cause PRODUTIVIDADE & & $\mathbf{9 , 9 2 8 4}$ & $0,02 \%$ \\
\hline ROYALTIES does not Granger Cause DIFPIB & 61 & 0,6276 & $53,76 \%$ \\
\hline DIFPIB does not Granger Cause ROYALTIES & & 0,9112 & $40,79 \%$ \\
\hline INVESTIMENTO does not Granger Cause DIFPIB & 61 & 4,6735 & $1,33 \%$ \\
\hline DIFPIB does not Granger Cause INVESTIMENTO & & 6,5545 & $\mathbf{0 , 2 8 \%}$ \\
\hline POUPANCA does not Granger Cause DIFPIB & 61 & 2,2860 & $11,11 \%$ \\
\hline DIFPIB does not Granger Cause POUPANCA & & 3,2432 & $4,65 \%$ \\
\hline DIFIED does not Granger Cause DIFPIB & 61 & 0,0218 & $97,84 \%$ \\
\hline DIFPIB does not Granger Cause DIFIED & & 0,1152 & $89,14 \%$ \\
\hline EXPORTACAO does not Granger Cause DIFPIB & 61 & 1,3331 & $27,19 \%$ \\
\hline DIFPIB does not Granger Cause EXPORTACAO & & 3,3290 & $4,31 \%$ \\
\hline COEFABERT does not Granger Cause DIFPIB & 61 & 5,0942 & $0,93 \%$ \\
\hline DIFPIB does not Granger Cause COEFABERT & & 10,0516 & $0,02 \%$ \\
\hline ROYALTIES does not Granger Cause PRODUTIVIDADE & 55 & 6,6690 & $0,27 \%$ \\
\hline PRODUTIVIDADE does not Granger Cause ROYALTIES & & 2,7558 & $\mathbf{7 , 3 2 \%}$ \\
\hline INVESTIMENTO does not Granger Cause PRODUTIVIDADE & 55 & 1,7883 & $17,78 \%$ \\
\hline PRODUTIVIDADE does not Granger Cause INVESTIMENTO & & 2,3655 & $10,43 \%$ \\
\hline POUPANCA does not Granger Cause PRODUTIVIDADE & 55 & 2,0638 & $13,77 \%$ \\
\hline PRODUTIVIDADE does not Granger Cause POUPANCA & & 0,4356 & $64,93 \%$ \\
\hline DIFIED does not Granger Cause PRODUTIVIDADE & 55 & 5,1591 & $0,92 \%$ \\
\hline PRODUTIVIDADE does not Granger Cause DIFIED & & 3,4276 & $4,03 \%$ \\
\hline EXPORTACAO does not Granger Cause PRODUTIVIDADE & 55 & 5,7146 & $\mathbf{0 , 5 8 \%}$ \\
\hline PRODUTIVIDADE does not Granger Cause EXPORTACAO & & $\mathbf{7 , 5 6 3 0}$ & $0,14 \%$ \\
\hline COEFABERT does not Granger Cause PRODUTIVIDADE & 55 & 1,5688 & $21,84 \%$ \\
\hline PRODUTIVIDADE does not Granger Cause COEFABERT & & 0,8124 & $44,95 \%$ \\
\hline INVESTIMENTO does not Granger Cause ROYALTIES & 61 & 1,6913 & $19,36 \%$ \\
\hline ROYALTIES does not Granger Cause INVESTIMENTO & & 2,7624 & $7,18 \%$ \\
\hline POUPANCA does not Granger Cause ROYALTIES & 61 & 1,6288 & $20,53 \%$ \\
\hline ROYALTIES does not Granger Cause POUPANCA & & 1,5850 & $21,40 \%$ \\
\hline DIFIED does not Granger Cause ROYALTIES & 61 & 2,0794 & $13,46 \%$ \\
\hline ROYALTIES does not Granger Cause DIFIED & & 0,4056 & $66,85 \%$ \\
\hline EXPORTACAO does not Granger Cause ROYALTIES & 62 & 3,0879 & $5,33 \%$ \\
\hline ROYALTIES does not Granger Cause EXPORTACAO & & 0,2349 & $79,14 \%$ \\
\hline COEFABERT does not Granger Cause ROYALTIES & 62 & 0,1681 & $84,57 \%$ \\
\hline ROYALTIES does not Granger Cause COEFABERT & & 0,1662 & $84,73 \%$ \\
\hline POUPANCA does not Granger Cause INVESTIMENTO & 61 & 3,8795 & $2,64 \%$ \\
\hline INVESTIMENTO does not Granger Cause POUPANCA & & 2,2143 & $11,87 \%$ \\
\hline DIFIED does not Granger Cause INVESTIMENTO & 61 & 0,5234 & $59,54 \%$ \\
\hline INVESTIMENTO does not Granger Cause DIFIED & & 0,8505 & $43,27 \%$ \\
\hline EXPORTACAO does not Granger Cause INVESTIMENTO & 61 & 2,6172 & $8,19 \%$ \\
\hline INVESTIMENTO does not Granger Cause EXPORTACAO & & 0,6193 & $54,20 \%$ \\
\hline COEFABERT does not Granger Cause INVESTIMENTO & 61 & 1,5120 & $22,93 \%$ \\
\hline INVESTIMENTO does not Granger Cause COEFABERT & & 2,0275 & $14,12 \%$ \\
\hline DIFIED does not Granger Cause POUPANCA & 61 & 0,6829 & $50,93 \%$ \\
\hline POUPANCA does not Granger Cause DIFIED & & 0,4529 & $63,81 \%$ \\
\hline EXPORTACAO does not Granger Cause POUPANCA & 61 & 2,3498 & $10,47 \%$ \\
\hline POUPANCA does not Granger Cause EXPORTACAO & & 0,3519 & $70,49 \%$ \\
\hline COEFABERT does not Granger Cause POUPANCA & 61 & 4,6205 & $1,39 \%$ \\
\hline
\end{tabular}


POUPANCA does not Granger Cause COEFABERT

EXPORTACAO does not Granger Cause DIFIED

DIFIED does not Granger Cause EXPORTACAO

COEFABERT does not Granger Cause DIFIED

DIFIED does not Granger Cause COEFABERT

COEFABERT does not Granger Cause EXPORTACAO

EXPORTACAO does not Granger Cause COEFABERT

, 6653

$61 \quad 4,7174$

9,3040

$61 \quad 0,4683$

0,2638

$62 \quad 0,8813$

0,8196

$51,81 \%$

$\mathbf{1 , 2 8 \%}$

$\mathbf{0 , 0 3 \%}$

$62,85 \%$

$76,91 \%$

$41,98 \%$

$44,57 \%$

Tabela 6.12 - Teste de Causalidade de Granger

O PIB apresenta relações de causalidade com investimento interno, poupança, coeficiente de abertura, produtividade e exportações. Com relação ao investimento interno e poupança, há relação de bicausalidade com o PIB. Isso significa dizer que investimento interno e poupança são bons preditores para o PIB e vice-versa. Uma observação quanto à poupança é que a probabilidade apresentada na tabela 6.12, para aceitação da hipótese nula, é alta (superior a 5\%). Isso significa que a poupança pode não causar aumento do PIB diretamente. Em outras palavras, a poupança indiretamente pode causar um aumento no PIB pois com o aumento da taxa de poupança há um aumento na taxa de investimento (que indiretamente causa aumento do PIB). A taxa de poupança determina o estoque de capital e portanto seu nível de produção. O aumento na taxa de poupança eleva os investimentos promovendo produtividade e crescimento econômico. Por outro lado, o aumento no PIB gera entrada de divisas que são aplicadas em forma de investimento e poupança.

A integração do Brasil no mercado internacional, medida através do coeficiente de abertura, também apresenta relação de bicausalidade com o PIB. Isso significa dizer que o aumento da integração comercial promove aumento do PIB e que o crescimento econômico estimula uma maior integração comercial com os países por meio do aumento de renda para os consumidores (importação) e a venda da produção nacional (exportação). O PIB ainda apresenta relações de causalidade unilateral com produtividade e exportações. Segundo os dados analisados, o PIB é um bom preditor para esses indicadores. Contudo, vale considerar 
que os indicadores Produtividade e Exportações apresentam duas defasagens. Isso significa que o crescimento econômico gera aumento de produtividade e aumento das exportações futuras. A recíproca não é verdadeira, ou seja, produtividade e exportações não causam, em Granger, PIB. Os indicadores Royalties e Licenças (progresso tecnológico) e IED (investimento externo em empresas) não apresentam relações de causalidade com o PIB.

A produtividade apresenta relações de bicausalidade com investimento estrangeiro direto, inovação tecnológica (royalties e licenças) e exportações. Em outras palavras, o aumento de investimento estrangeiro direto, direcionado à pesquisa e desenvolvimento e inovação tecnológica, promove aumento de produtividade e, conseqüentemente maior competitividade. Com o aumento de competitividade, as empresas vendem mais e se tornam mais atrativas para investidores.

Pela alta probabilidade de não rejeitar a hipótese nula observada na tabela 6.12 , pode-se dizer que, no sentido Granger, produtividade não causa investimento em tecnologia. Outras constatações de relação de causalidade (não rejeitadas pelo teste F) foram rejeitadas pela alta probabilidade de aceitar a hipótese nula de não-causalidade. Os casos em questão são as relações de causalidade unilateral entre produtividade e investimento interno (o aumento da produtividade não é um bom preditor para o aumento do investimento interno, até mesmo porque a produtividade é defasada) e as relações entre poupança e produtividade (o aumento na taxa de poupança não causa, no sentido Granger, produtividade). Com relação à inovação tecnológica, a única relação de causalidade aceita pelo teste $\mathrm{F}$ e pela probabilidade de rejeição da hipótese nula é que inovação tecnológica causa aumento de produtividade futura. Outras relações de causalidade, aceitas pelo teste $\mathrm{F}$, foram rejeitadas pela alta probabilidade de não 
rejeição da hipótese nula. Essas relações são de que investimento estrangeiro direto e exportações causam, no sentido Granger, inovação tecnológica.

A poupança, segundo o Teste de Granger, apresenta relação de causalidade bilateral com investimento interno e PIB. A taxa de poupança é um bom preditor para investimento interno, porém, a recíproca não é verdadeira, pois há alta probabilidade de não rejeição da hipótese nula de não-causalidade. O mesmo acontece com o PIB. O crescimento econômico (PIB) também é um bom preditor para poupança, porém a poupança não é boa preditora para crescimento econômico. A tabela 6.12 aponta ainda que a abertura comercial é boa preditora para poupança, contudo essa variável apresenta defasagem. Ao nível de significância de 5\%, existe uma relação de bicausalidade entre investimento interno e PIB. Dessa forma, o aumento de investimento interno causa, no sentido Granger, crescimento econômico. Por outro lado, o crescimento econômico gera divisas a serem aplicadas como investimento interno. A poupança apresenta relação de causalidade bilateral com investimento interno, sendo a poupança um bom preditor para investimento. Produtividade, inovação tecnológica e exportações, por serem defasadas, não são bons preditores para investimento interno.

Os investimentos externos diretos apresentam relação de bicausalidade com produtividade e exportações. Isso corrobora a idéia de que a entrada de investimento externo, direcionado à reestruturação das empresas, provoca aumento de produtividade e conseqüente competitividade. $\mathrm{O}$ aumento de produtividade, por outro lado, atrai mais investimentos para essas empresas. Pode-se dizer então, que investimentos externos diretos são bons preditores para produtividade (e vice-versa). Com relação às exportações, deve-se considerar que existe defasagem. Assim, conclui-se que os investimentos externos diretos são bons preditores para as exportações. Outra consideração com relação aos IEDs, é que, pelo teste F, os 
investimentos externos causam, no sentido Granger, inovação tecnológica. Contudo, nesse último caso, existe alta probabilidade de rejeitar a hipótese nula de causalidade.

Segundo o teste de Granger, o crescimento econômico é um bom preditor para exportações. Relacionados às exportações, o investimento estrangeiro direto e a produtividade apresentam relações de bicausalidade com exportações. Contudo, como investimento estrangeiro direto apresenta uma defasagem, e exportações e produtividade apresentam duas defasagens, inferese que os investimentos estrangeiros causam, no sentido Granger, aumento de produtividade (maior competitividade) e que essa maior competitividade causa, no sentido Granger, exportações.

O coeficiente de abertura apresenta relação de bicausalidade com o PIB. Contudo, como essa variável é defasada, infere-se que crescimento econômico causa, no sentido Granger, maior abertura e integração. O resultado da existência de causalidade para as demais combinações de séries não indica necessariamente relação de causalidade, mas pode significar uma adequação do modelo VAR para o estudo do nível de interdependência entre essas séries.

\subsection{ANÁLISE DAS DECOMPOSIÇÕES DA VARIÂNCIA}

O modelo VAR aplicado apresentou resultados que indicaram não haver qualquer nível de correlação entre os elementos da matriz de correlação dos resíduos que seja significativamente diferente de zero. Isto indica a necessidade da aplicação de um processo de decomposição de Cholesky para estimar as Decomposições da Variância, e que as Funções de Resposta a Impulso não são significativamente afetadas pela ordem das variáveis. 


\begin{tabular}{|c|c|c|c|c|c|c|c|c|c|}
\hline \multicolumn{10}{|c|}{ Decomposição da Variância para DIFPIB: } \\
\hline Period & S.E. & DIFPIB & PRODUTIVIDADE & ROYALTIES & INVESTIMENTO & POUPANCA & IED & EXPORTACAO & COEFABERT \\
\hline 2 & 50954250 & 83.84505 & 0.821233 & 0.010546 & 0.147148 & 0.000286 & 0.491798 & 3.466091 & 11.21784 \\
\hline 4 & 59054814 & 70.47747 & 1.184294 & 0.549787 & 1.517503 & 0.147950 & 0.601512 & 4.434524 & 21.08696 \\
\hline 5 & 60164304 & 69.85247 & 1.141990 & 0.774043 & 1.473436 & 0.154248 & 1.351297 & 4.375871 & 20.87664 \\
\hline 6 & 61191566 & 68.91844 & 1.633624 & 1.020633 & 1.694266 & 0.769492 & 1.518187 & 4.253570 & 20.19179 \\
\hline 9 & 62004647 & 67.92369 & 1.661776 & 1.257665 & 1.896786 & 0.944979 & 1.734995 & 4.187795 & 20.39232 \\
\hline 10 & 62161034 & 67.67136 & 1.733146 & 1.350401 & 1.916005 & 1.101392 & 1.764417 & 4.173196 & 20.29008 \\
\hline
\end{tabular}

Tabela 6.13 - Decomposição da Variância para PIB

\begin{tabular}{|c|c|c|c|c|c|c|c|c|c|}
\hline \multicolumn{10}{|c|}{ Decomposição da Variância para PRODUTIVIDADE: } \\
\hline Period & S.E. & DIFPIB & PRODUTIVIDADE & ROYALTIES & INVESTIMENTO & POUPANCA & IED & EXPORTACAO & COEFABERT \\
\hline 1 & 4.620307 & 2.426526 & 97.57347 & 0.000000 & 0.000000 & 0.000000 & 0.000000 & 0.000000 & 0.000000 \\
\hline 2 & 6.889891 & 4.778668 & 81.52656 & 1.092933 & 0.019536 & 2.098891 & 2.143782 & 7.179739 & 1.159888 \\
\hline 4 & 8.382404 & 8.641608 & 60.68047 & 5.243416 & 0.571369 & 2.021703 & 9.622558 & 10.39721 & 2.821667 \\
\hline 5 & 8.968429 & 9.341686 & 57.21288 & 8.437714 & 0.508225 & 2.034917 & 8.650222 & 11.24069 & 2.573674 \\
\hline 6 & 9.565479 & 8.317025 & 53.84704 & 10.53051 & 0.857925 & 1.788827 & 8.399779 & 13.77009 & 2.488801 \\
\hline 9 & 11.18158 & 7.093168 & 41.91938 & 15.44008 & 1.270020 & 1.951008 & 9.930129 & 20.15485 & 2.241376 \\
\hline 10 & 11.82283 & 6.350969 & 38.60125 & 15.57346 & 1.691989 & 1.768164 & 10.10180 & 23.50714 & 2.405227 \\
\hline
\end{tabular}

Tabela 6.14 - Decomposição da Variância para Produtividade 


\begin{tabular}{|c|c|c|c|c|c|c|c|c|c|}
\hline \multicolumn{10}{|c|}{ Decomposição da Variância para ROYALTIES: } \\
\hline Period & S.E. & DIFPIB & PRODUTIVIDADE & ROYALTIES & INVESTIMENTO & POUPANCA & IED & EXPORTACAO & COEFABERT \\
\hline 1 & 52.51054 & 1.111012 & 8.914914 & 89.97407 & 0.000000 & 0.000000 & 0.000000 & 0.000000 & 0.000000 \\
\hline 2 & 57.65311 & 2.109882 & 7.395777 & 87.33262 & 0.469072 & 0.040413 & 1.547145 & 0.693198 & 0.411894 \\
\hline 4 & 68.69623 & 1.637825 & 5.376211 & 80.53571 & 0.976400 & 3.624836 & 2.458373 & 2.733125 & 2.657515 \\
\hline 5 & 74.38705 & 2.053158 & 4.694390 & 76.27514 & 1.958978 & 5.120628 & 2.708646 & 3.933729 & 3.255332 \\
\hline 6 & 78.86647 & 2.562961 & 4.216037 & 72.53961 & 2.578826 & 5.749466 & 2.530449 & 5.538154 & 4.284498 \\
\hline 9 & 90.87862 & 2.184305 & 3.296374 & 60.02157 & 4.137126 & 5.384967 & 4.361738 & 15.83214 & 4.781784 \\
\hline 10 & 95.01897 & 2.131492 & 3.174479 & 55.38872 & 4.197242 & 4.950632 & 4.900241 & 20.38702 & 4.870177 \\
\hline
\end{tabular}

Tabela 6.15 - Decomposição da Variância para Royalties e Licenças

\begin{tabular}{|c|c|c|c|c|c|c|c|c|c|}
\hline \multicolumn{10}{|c|}{ Decomposição da Variância para INVESTIMENTO: } \\
\hline Period & S.E. & DIFPIB & PRODUTIVIDADE & ROYALTIES & INVESTIMENTO & POUPANCA & IED & EXPORTACAO & COEFABERT \\
\hline 1 & 0.019266 & 0.724181 & 4.477478 & 9.550553 & 85.24779 & 0.000000 & 0.000000 & 0.000000 & 0.000000 \\
\hline 2 & 0.023871 & 8.227151 & 8.120161 & 13.91879 & 59.90045 & 4.768137 & 2.210386 & 0.109968 & 2.744963 \\
\hline 4 & 0.027036 & 9.624156 & 8.480113 & 14.01199 & 47.01779 & 6.655758 & 2.359207 & 3.999338 & 7.851641 \\
\hline 5 & 0.027223 & 9.633381 & 8.417074 & 13.91287 & 47.21725 & 6.662243 & 2.423245 & 3.947432 & 7.786503 \\
\hline 6 & 0.027355 & 9.781064 & 8.465930 & 13.77994 & 46.78985 & 6.626799 & 2.867687 & 3.911973 & 7.776754 \\
\hline 9 & 0.027596 & 9.979833 & 8.384227 & 13.61958 & 46.08903 & 6.743015 & 3.050319 & 4.323778 & 7.810215 \\
\hline 10 & 0.027634 & 9.988836 & 8.364948 & 13.65224 & 45.96351 & 6.781309 & 3.117384 & 4.336416 & 7.795359 \\
\hline
\end{tabular}

Tabela 6.16 - Decomposição da Variância para Investimento Interno 


\begin{tabular}{|c|c|c|c|c|c|c|c|c|c|}
\hline \multicolumn{10}{|c|}{ Decomposição da Variância para POUPANCA: } \\
\hline Period & S.E. & DIFPIB & PRODUTIVIDADE & ROYALTIES & INVESTIMENTO & POUPANCA & IED & EXPORTACAO & COEFABERT \\
\hline 1 & 0.030732 & 6.629869 & 0.348357 & 19.32771 & 30.17879 & 43.51527 & 0.000000 & 0.000000 & 0.000000 \\
\hline 2 & 0.034459 & 10.82707 & 1.517664 & 16.42547 & 24.50160 & 39.36182 & 2.736414 & 0.684199 & 3.945771 \\
\hline 4 & 0.039684 & 13.72870 & 4.324284 & 20.41433 & 20.23160 & 29.67843 & 2.186610 & 4.484582 & 4.951463 \\
\hline 5 & 0.040635 & 13.44984 & 4.132884 & 20.08202 & 19.45114 & 29.07952 & 2.110782 & 6.065725 & 5.628085 \\
\hline 6 & 0.041715 & 13.60500 & 4.234956 & 20.27897 & 18.59351 & 29.11838 & 2.887034 & 5.913681 & 5.368474 \\
\hline 9 & 0.043583 & 12.89493 & 5.283351 & 21.40592 & 17.28494 & 27.66704 & 2.955744 & 7.245322 & 5.262751 \\
\hline 10 & 0.044081 & 12.71344 & 5.476830 & 21.56813 & 16.89681 & 27.60808 & 3.166274 & 7.417968 & 5.152470 \\
\hline
\end{tabular}

Tabela 6.17 - Decomposição da Variância para Poupança

\begin{tabular}{|c|c|c|c|c|c|c|c|c|c|}
\hline \multicolumn{10}{|c|}{ Decomposição da Variância para IED: } \\
\hline Period & S.E. & DIFPIB & PRODUTIVIDADE & ROYALTIES & INVESTIMENTO & POUPANCA & IED & EXPORTACAO & COEFABERT \\
\hline 1 & 1739.307 & 0.011399 & 3.035378 & 3.470708 & 1.416253 & 4.698072 & 87.36819 & 0.000000 & 0.000000 \\
\hline 2 & 2104.523 & 0.096656 & 3.575258 & 3.810091 & 1.376097 & 4.948382 & 82.87806 & 1.578100 & 1.737355 \\
\hline 4 & 2225.897 & 0.547515 & 8.105566 & 5.593558 & 1.814248 & 5.552281 & 74.20365 & 2.364357 & 1.818820 \\
\hline 5 & 2251.295 & 1.016176 & 8.104706 & 5.556752 & 1.893648 & 5.485874 & 73.81607 & 2.336956 & 1.789823 \\
\hline 6 & 2272.729 & 1.013013 & 8.007507 & 5.455792 & 2.238127 & 5.424389 & 73.23279 & 2.713214 & 1.915171 \\
\hline 9 & 2294.265 & 1.802026 & 8.350585 & 5.369229 & 2.233674 & 5.402406 & 72.03606 & 2.807388 & 1.998638 \\
\hline 10 & 2296.590 & 1.818589 & 8.345445 & 5.358423 & 2.306717 & 5.406052 & 71.93059 & 2.831516 & 2.002672 \\
\hline
\end{tabular}

Tabela 6.18 - Decomposição da Variância para Investimento Estrangeiro Direto 


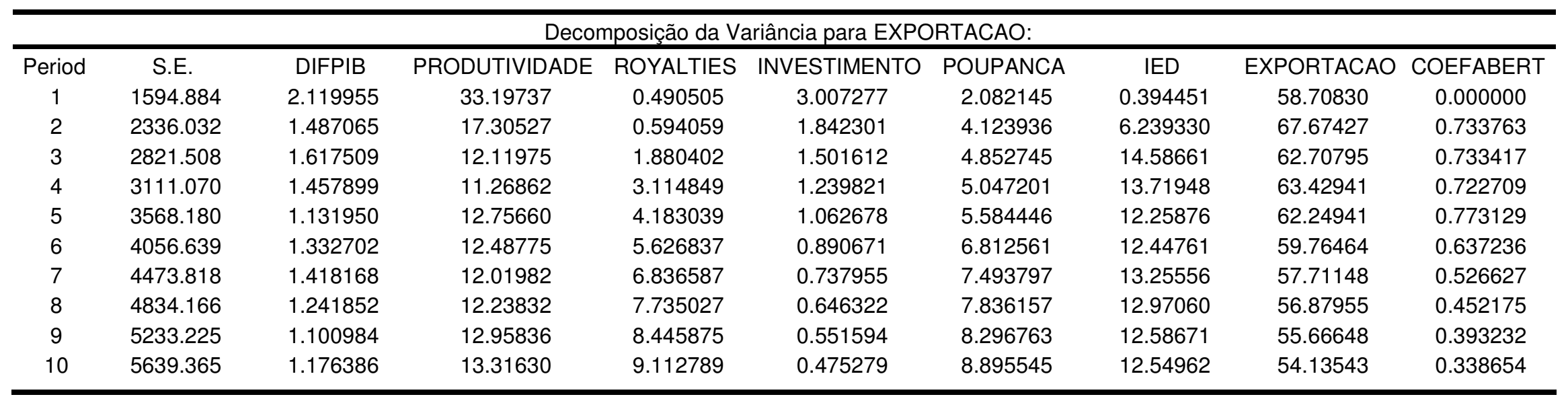

Tabela 6.19 - Decomposição da Variância para Exportação

\begin{tabular}{|c|c|c|c|c|c|c|c|c|c|}
\hline \multicolumn{10}{|c|}{ Decomposição da Variância para COEFABERT: } \\
\hline Period & S.E. & DIFPIB & PRODUTIVIDADE & ROYALTIES & INVESTIMENTO & POUPANCA & IED & EXPORTACAO & COEFABERT \\
\hline 1 & 0.083485 & 59.84374 & 11.60272 & 0.364432 & 0.907249 & 4.319794 & 0.000235 & 0.065812 & 22.89603 \\
\hline 2 & 0.100444 & 44.92001 & 8.085703 & 1.064736 & 5.098453 & 5.137618 & 0.074557 & 0.307680 & 35.31124 \\
\hline 4 & 0.110219 & 42.19746 & 7.486373 & 1.722040 & 7.241089 & 6.961291 & 0.486590 & 2.958639 & 30.94651 \\
\hline 5 & 0.115233 & 40.33670 & 7.761833 & 3.543837 & 6.720939 & 8.355440 & 0.898289 & 2.779178 & 29.60378 \\
\hline 6 & 0.116526 & 39.44702 & 7.604992 & 3.972639 & 7.530584 & 8.428240 & 0.889826 & 2.764007 & 29.36270 \\
\hline 9 & 0.118262 & 38.61393 & 7.882351 & 4.364793 & 7.591181 & 8.599768 & 0.943191 & 3.345636 & 28.65916 \\
\hline 10 & 0.118721 & 38.33380 & 7.821876 & 4.331269 & 7.647343 & 8.537166 & 1.002994 & 3.817064 & 28.50849 \\
\hline
\end{tabular}

Tabela 6.20 - Decomposição da Variância para Coeficiente de Abertura 
As tabelas 6.13 a 6.20 apresentam a influência dos oito indicadores na explicação da variância do comportamento de cada indicador. Os dados da decomposição da variância mostram que, no curto prazo, a maior parte dos desvios projetados da variância dos indicadores se explica por impactos nos próprios indicadores. As exceções ficam por conta da poupança, exportações e coeficiente de abertura.

Segundo a tabela 6.13, tem-se, no curto prazo, que $100 \%$ da variância do PIB se deve a ele mesmo. Contudo, em longo prazo, o PIB tem apenas $67 \%$ de sua variância explicada por ele mesmo, sendo que cerca de $20 \%$ da variância é explicada pela integração comercial (coeficiente de abertura) e $4 \%$ explicado pelas exportações. Dessa forma, entende-se que o crescimento econômico e a integração comercial explica, juntamente com as exportações, boa parte do crescimento econômico. Esse dado é relevante, uma vez que se busca neste trabalho identificar relações importantes entre fluxos de capitais externos e crescimento econômico. A explicação da variância da produtividade se dá, no curto prazo, por ela mesma $(97,5 \%)$, segundo dados da tabela 6.14. Contudo, no longo prazo, as exportações, a inovação tecnológica (Royalties) e o investimento estrangeiro direto também influenciam esse indicador. Assim, pode-se inferir que as exportações exigem um nível de competitividade mais alto dos produtos exportados. Assim, o investimento estrangeiro direto, direcionado à inovação tecnológica e aumento de competitividade, promove aumento de produtividade.

Conforme dados da tabela 6.15, a inovação tecnológica é influenciada, em curto prazo, por alterações na variância da própria variável $(90 \%)$ e pela produtividade $(8,9 \%)$. No entanto, no longo prazo, o poder de explicação da inovação tecnológica se dá, além das flutuações da própria variável $(55,4 \%)$, pelas exportações $(20,4 \%)$, além de vários fatores combinados 
(investimento estrangeiro direto, poupança, investimento interno e abertura comercial). A tabela 6.16 revela que, em curto prazo, o investimento interno explica $85,2 \%$ de sua variância e que a inovação tecnológica $(9,6 \%)$ e produtividade $(4,5 \%)$ tem influência na explicação da variância desse indicador. No longo prazo, a capacidade de explicação da variância do investimento interno por ele mesmo cai para cerca de $46 \%$. Os outros fatores que influenciam o comportamento do investimento interno são, além de inovação tecnológica $(13,7 \%)$ e produtividade $(8,4 \%)$, o crescimento econômico $(10 \%)$, o coeficiente de abertura $(7,8 \%)$ e a poupança $(6,8 \%)$.

De acordo com a tabela 6.17, a explicação da variância da poupança se dá por vários fatores. No curto prazo, sua variância é explicada por ela mesma (43,5\%), pelo investimento interno (30,2\%), pela inovação tecnológica $(19,3 \%)$ e pelo PIB $(6,6 \%)$. No longo prazo, praticamente os mesmos fatores continuam a explicar a variância da poupança, ou seja, a própria poupança (27,6\%), a inovação tecnológica (21,6\%), o investimento interno (16,9\%), o crescimento econômico $(12,7 \%)$ e outros fatores pulverizados. A variância do investimento estrangeiro direto é explicada, em curto prazo, por cerca de $87,4 \%$ de sua própria variação. Segundo a tabela 6.18, os outros fatores que em curto prazo influenciam os investimentos externos são a produtividade (3\%), a inovação tecnológica $(3,5 \%)$, os investimentos internos $(1,4 \%)$ e a poupança $(4,7 \%)$. Em longo prazo, a capacidade de explicação da variância do investimento estrangeiro direto por ele mesmo cai para 71,9\%, enquanto outros fatores ficam pulverizados, com destaque para a produtividade $(8,34 \%)$, inovação tecnológica $(5,4 \%)$ e poupança $(5,4 \%)$.

Os números apontados na tabela 6.19 mostram que apenas 58,7\% dos desvios da variância das exportações se explica por variações no próprio indicador no curto prazo. Os outros fatores que influenciam a variância das exportações são a produtividade $(33,2 \%)$, investimento 
interno $(3 \%)$ e poupança $(2,1 \%)$ e crescimento econômico $(2,1 \%)$. No longo prazo, os principais fatores que explicam a variância das exportações são a produtividade $(13,3 \%)$, os investimento externos diretos $(12,5 \%)$, a inovação tecnológica $(9,1 \%)$ e a poupança $(8,9 \%)$, além da própria exportação $(54,1 \%)$. No caso da abertura econômica, os principais fatores que explicam sua variância são o PIB $(59,9 \%)$, a produtividade $(11,6 \%)$, a poupança $(4,3 \%)$ e o próprio coeficiente de abertura (22,9\%). Nota-se então que, de acordo com a tabela 6.20 , a abertura econômica é influenciada por vários fatores e que a explicação, tanto em curto quanto longo prazo, não se dá a variações na própria variável. A explicação da variância do coeficiente de abertura, em longo prazo, é devida à vários fatores. O PIB e a produtividade perdem poder de explicação (38,3\% e 7,8\% respectivamente). Em contrapartida, a poupança $(8,5 \%)$ e o investimento interno $(7,6 \%)$ merecem destaque na abertura comercial.

\subsection{ANÁLISE DAS FUNÇÕES DE RESPOSTA AO IMPULSO}

Os resultados das Funções de Resposta ao Impulso (FRI) de cada indicador (crescimento, fluxos de bens e capitais externos) a impulsos de um desvio padrão sobre cada um dos demais indicadores estão apresentados nas figuras 6.1 a 6.8. A linha cheia em cada gráfico corresponde aos pontos estimados da função de resposta ao impulso de cada indicador ao impulso dos outros indicadores, em uma unidade de desvio-padrão respectivas a eles. As linhas pontilhadas representam uma faixa de duas unidades de desvio-padrão do ponto estimado, para mais ou para menos. Se a faixa entre linhas pontilhadas inclui o eixo horizontal (eixo zero), o efeito é considerado insignificante. 
Response to Cholesky One S.D. Innovations \pm 2 S.E.
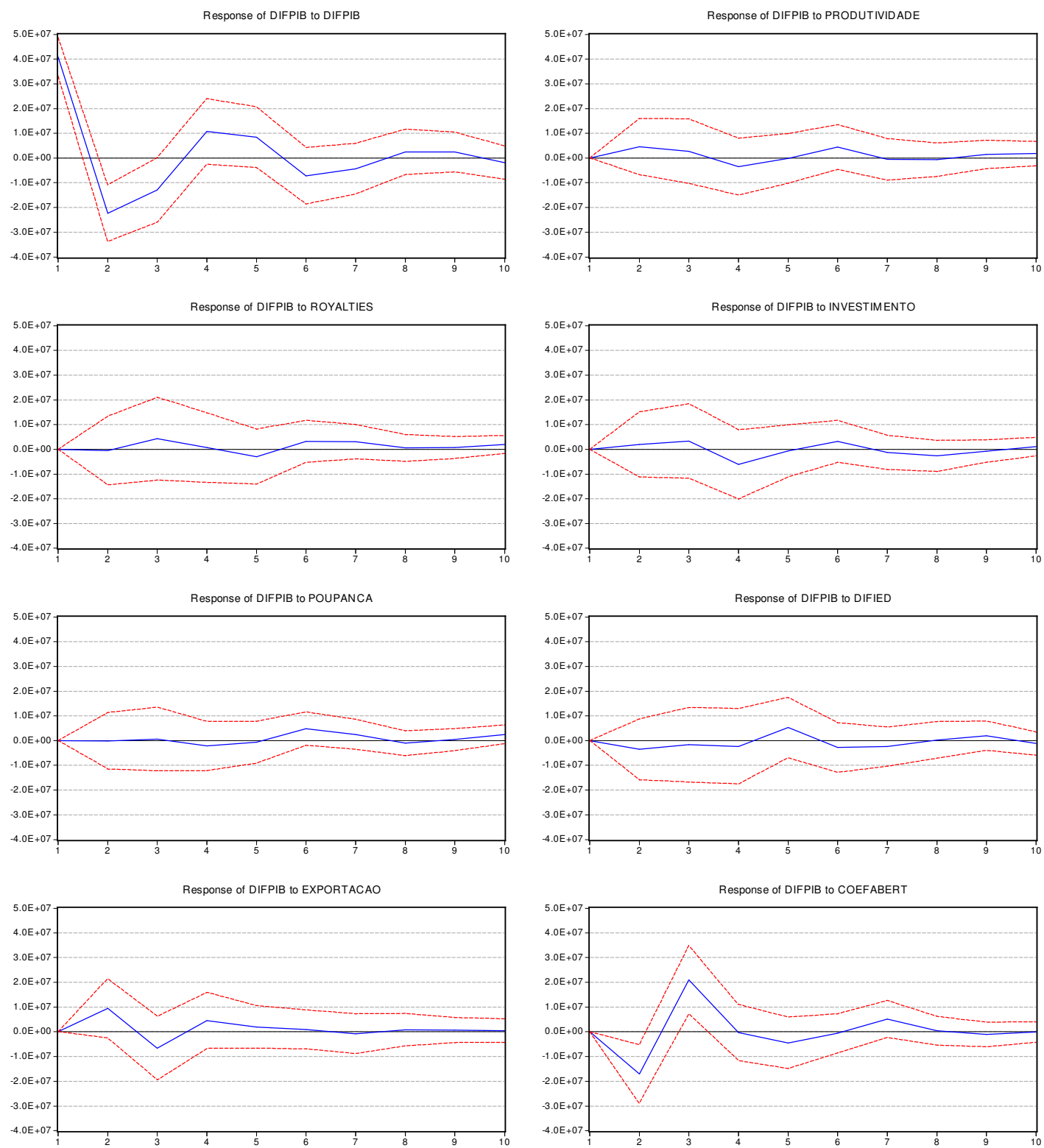

Gráfico 6.1 - Função de Resposta a Impulso para PIB 
Response to Cholesky One S.D. Innovations \pm 2 S.E.

Response of PRODUTIVIDADE to DIFPIB

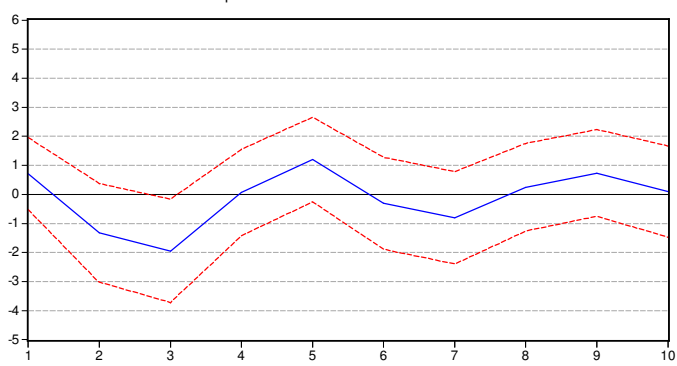

Response of PRODUTIVIDADE to ROYALTIES

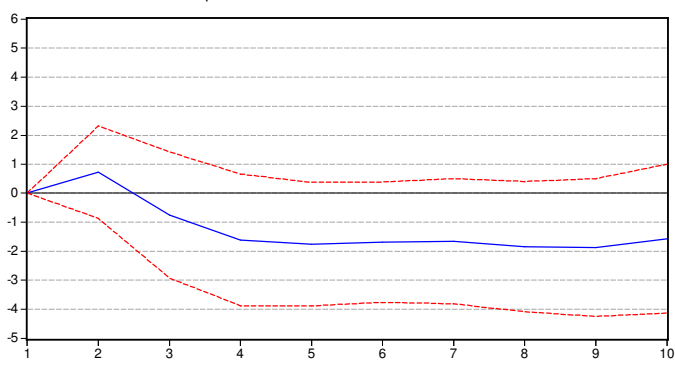

Response of PRODUTIVIDADE to POUPANCA

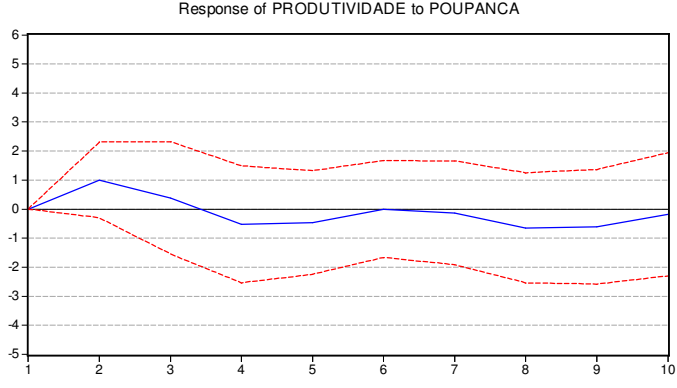

Response of PRODUTIVIDADE to EXPORTACAO

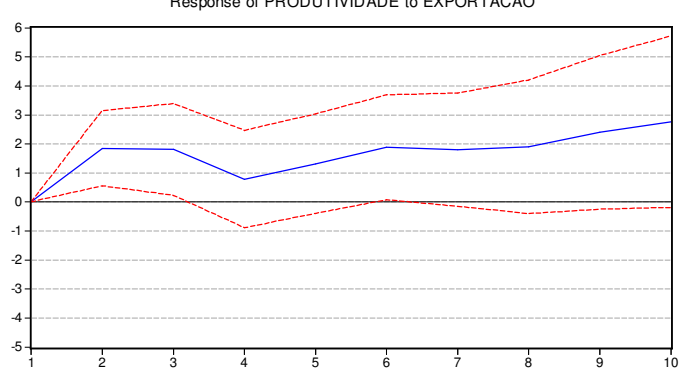

Response of PRODUTIVIDADE to PRODUTIVIDADE

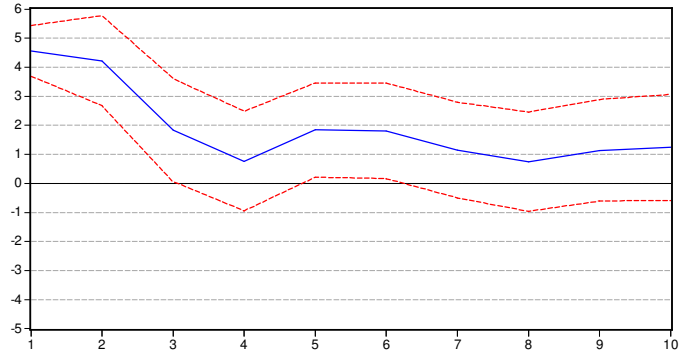

Response of PRODUTIVIDADE to INVESTIMENTO

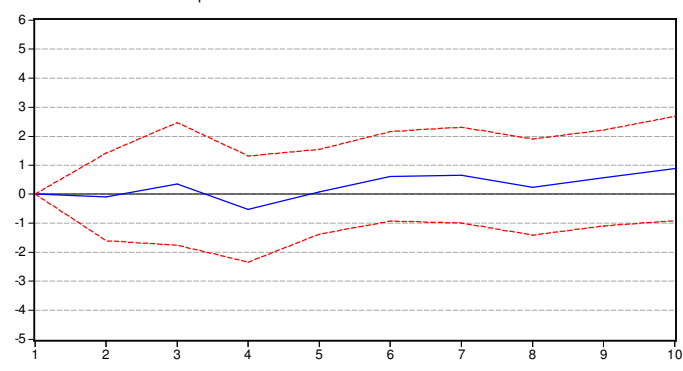

Response of PRODUTIVIDADE to DIFIED

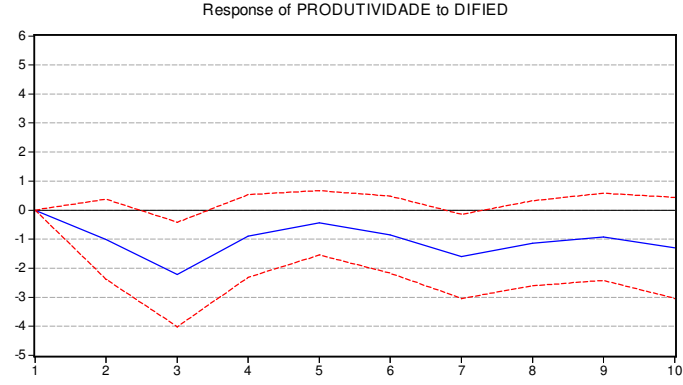

Response of PRODUTIVIDADE to COEFABERT

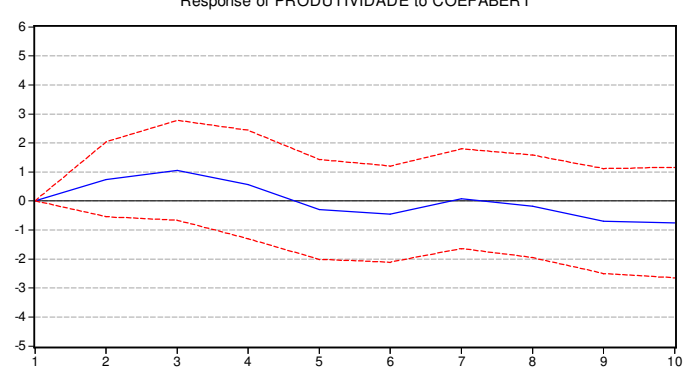

Gráfico 6.2 - Função de Resposta a Impulso para Produtividade 
Response to Cholesky One S.D. Innovations \pm 2 S.E.
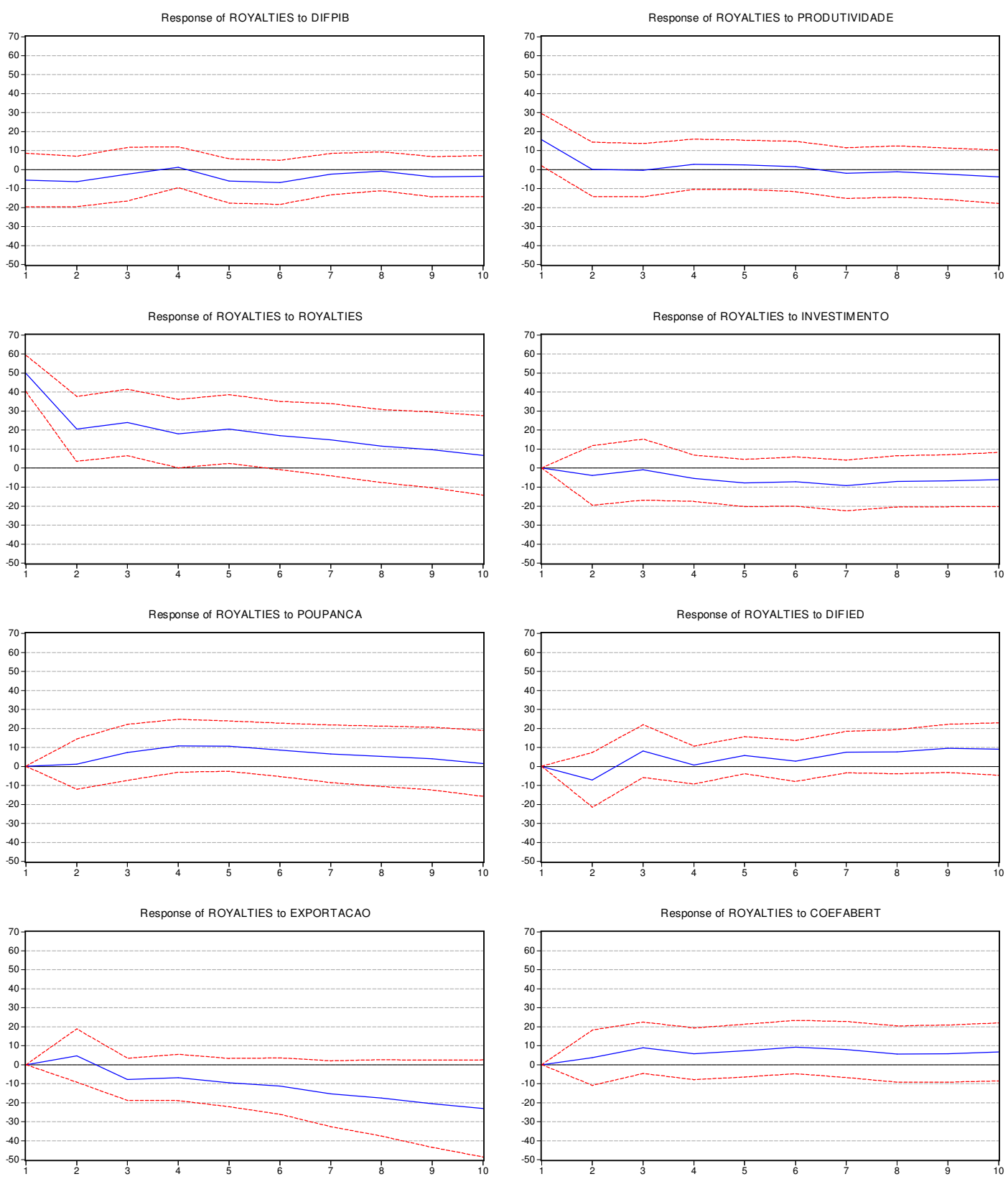

Gráfico 6.3 - Função de Resposta a Impulso para Royalties e Licenças 
Response to Cholesky One S.D. Innovations \pm 2 S.E.
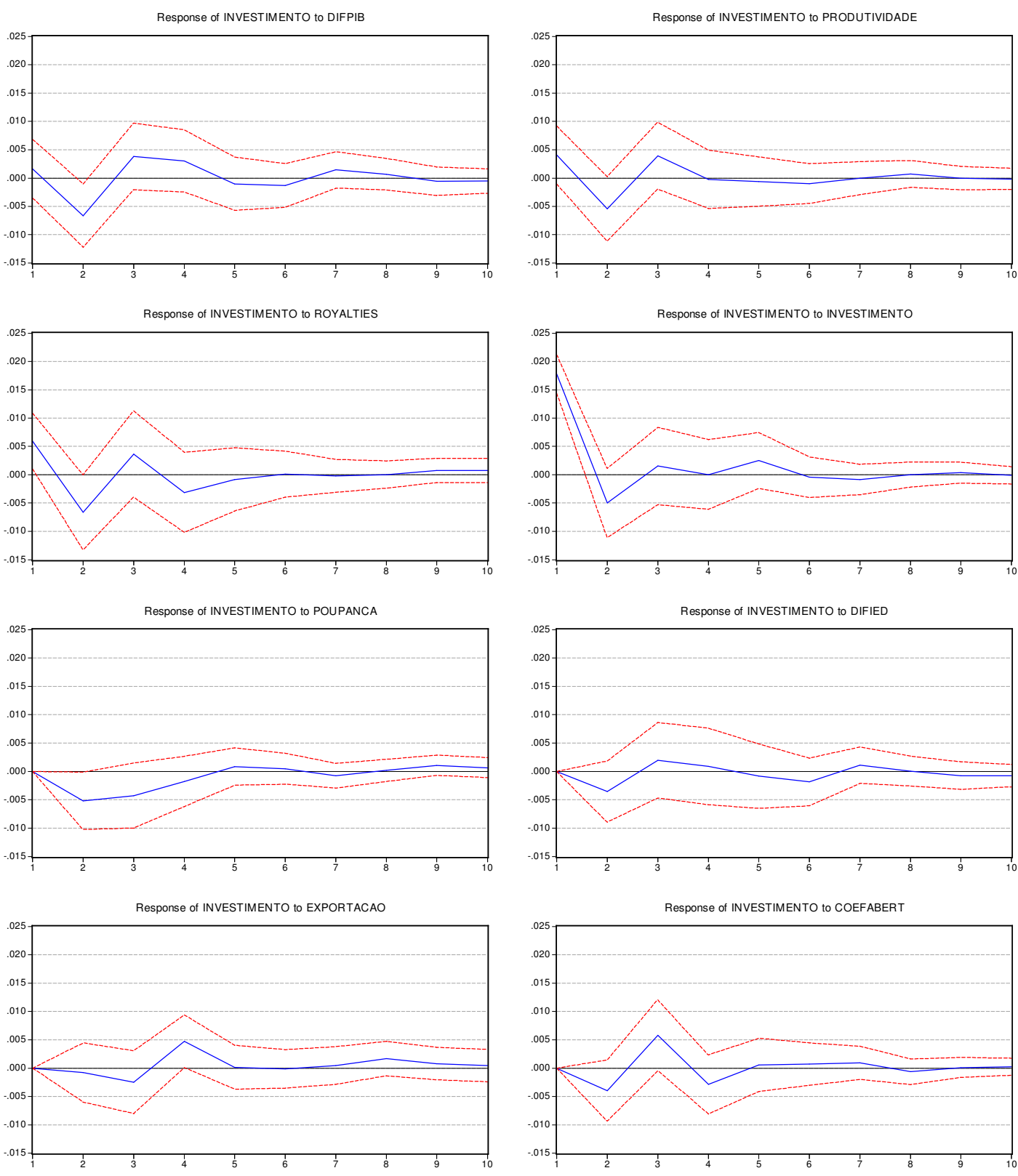

Gráfico 6.4 - Função de Resposta a Impulso para Investimento Interno 
Response to Cholesky One S.D. Innovations \pm 2 S.E.
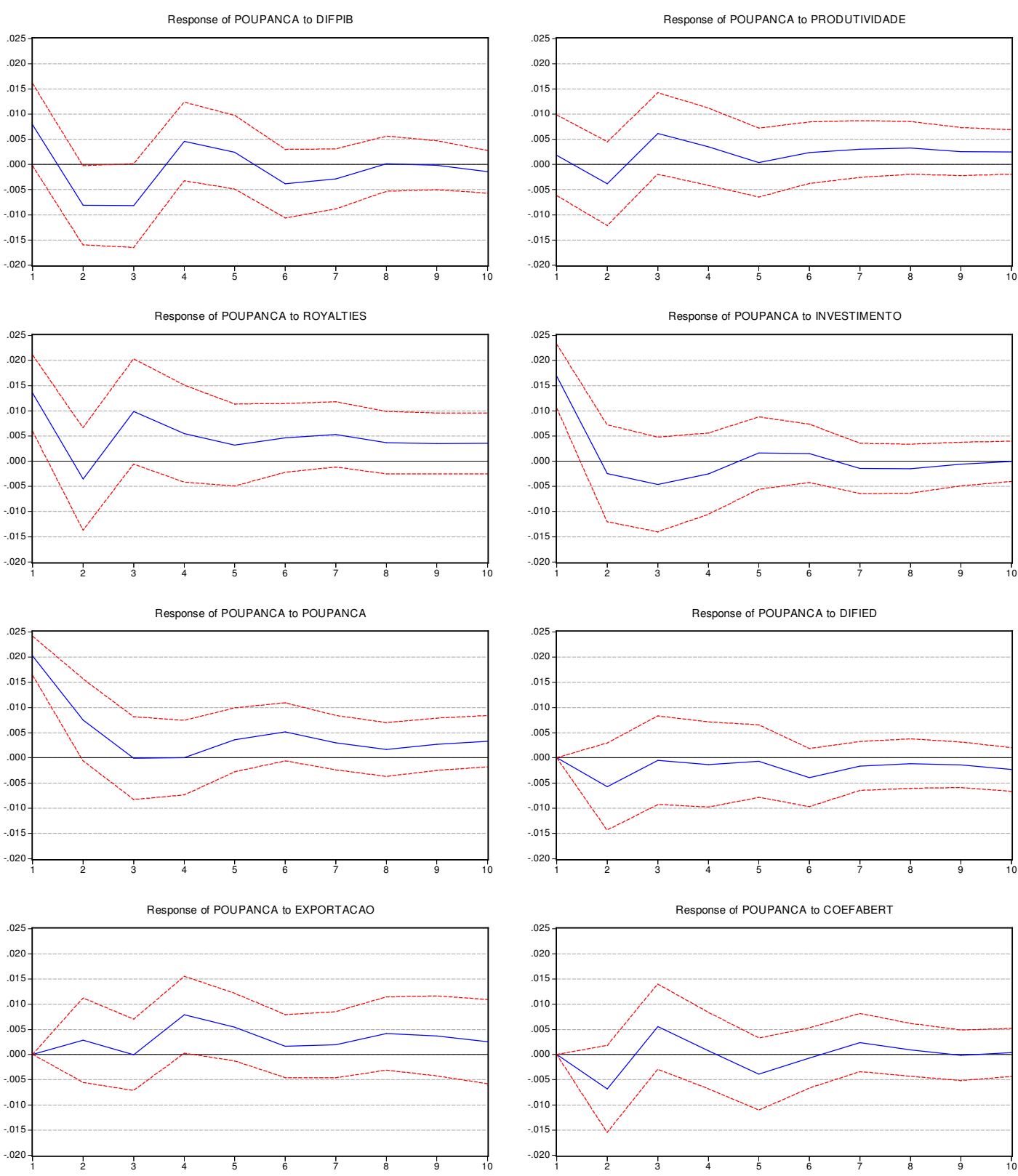

Gráfico 6.5 - Função de Resposta a Impulso para Poupança 
Response to Cholesky One S.D. Innovations \pm 2 S.E.
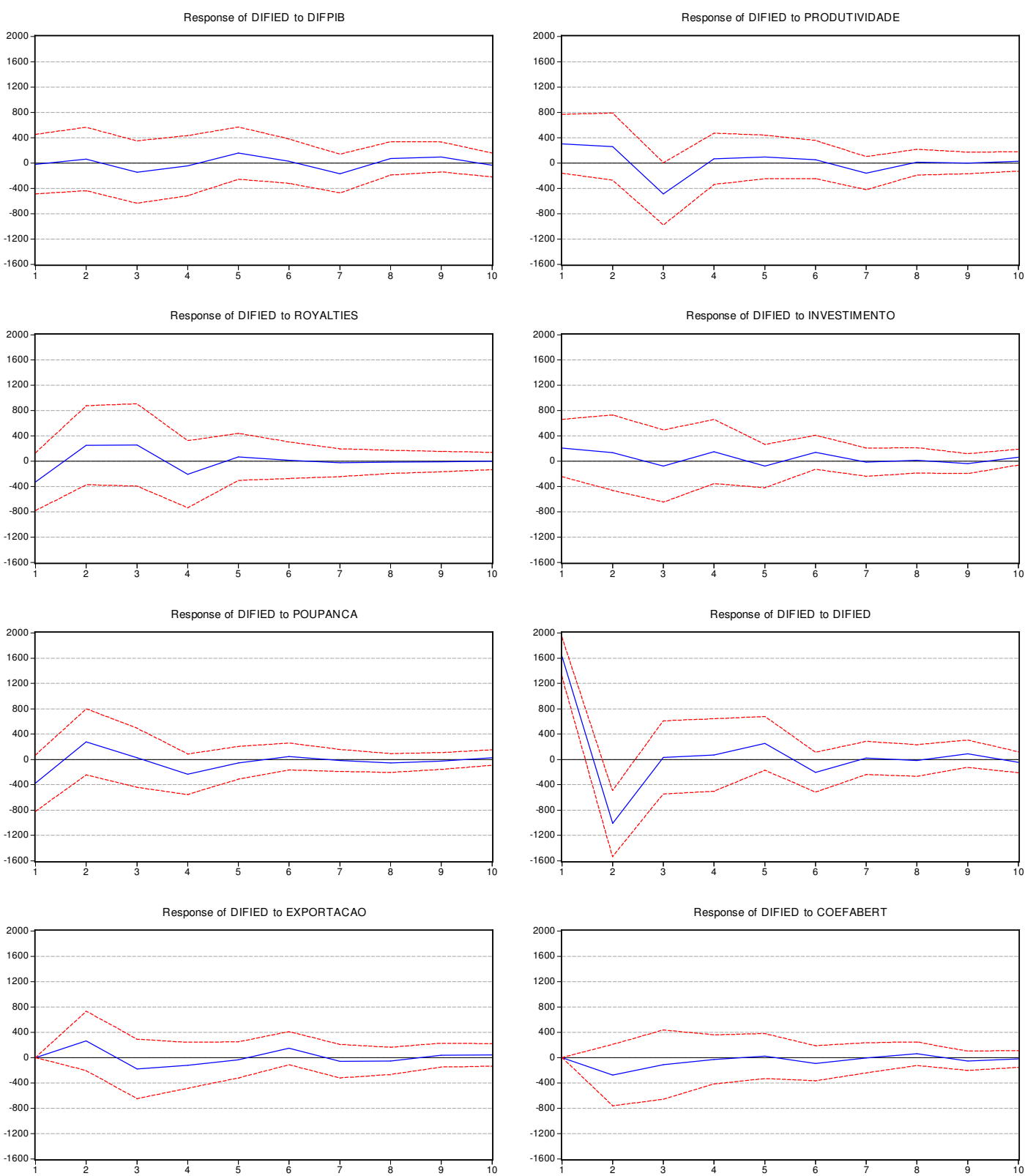

Gráfico 6.6 - Função de Resposta a Impulso para Investimento Estrangeiro Direto 
Response to Cholesky One S.D. Innovations \pm 2 S.E.
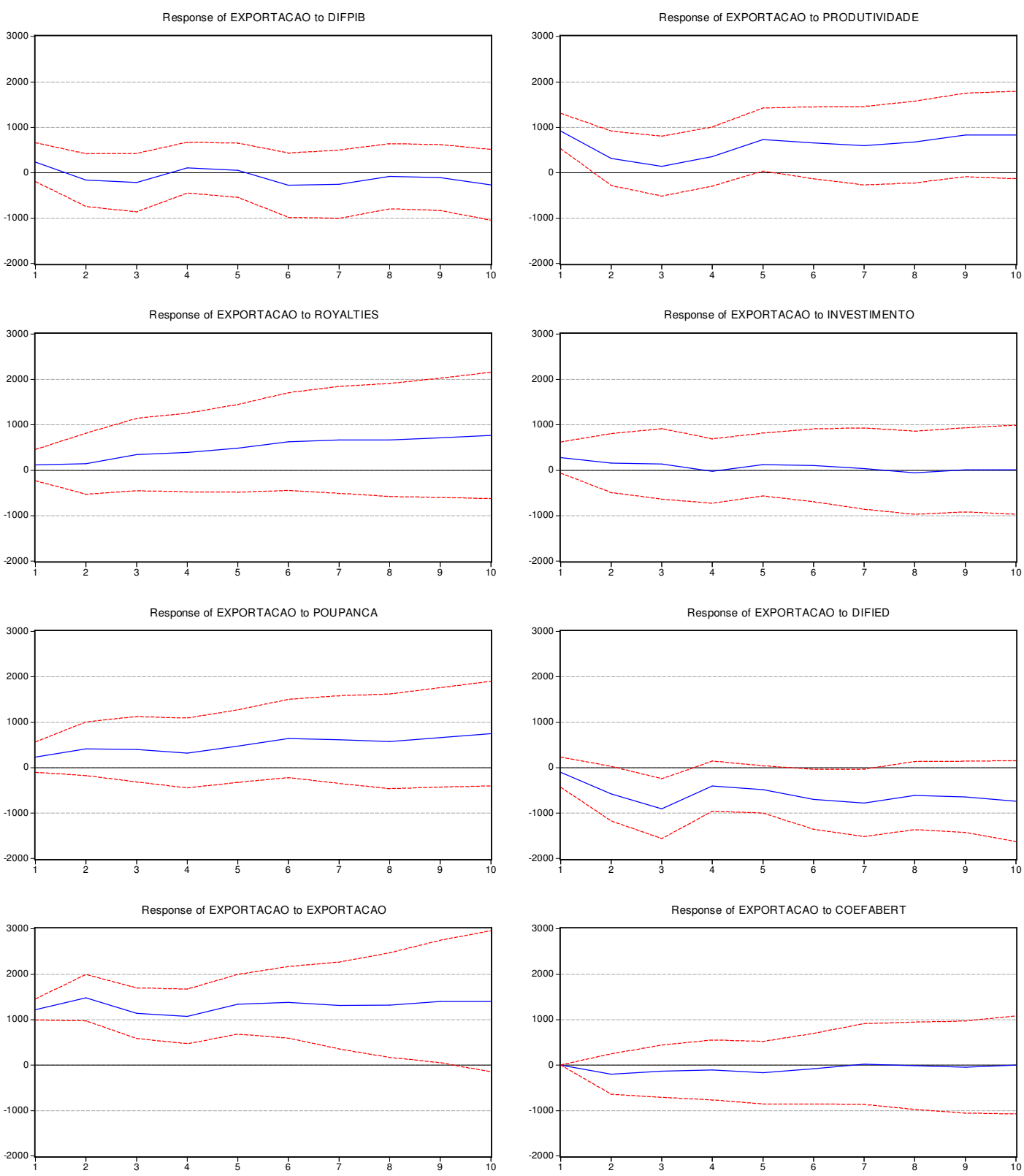

Gráfico 6.7 - Função de Resposta a Impulso para Exportação 

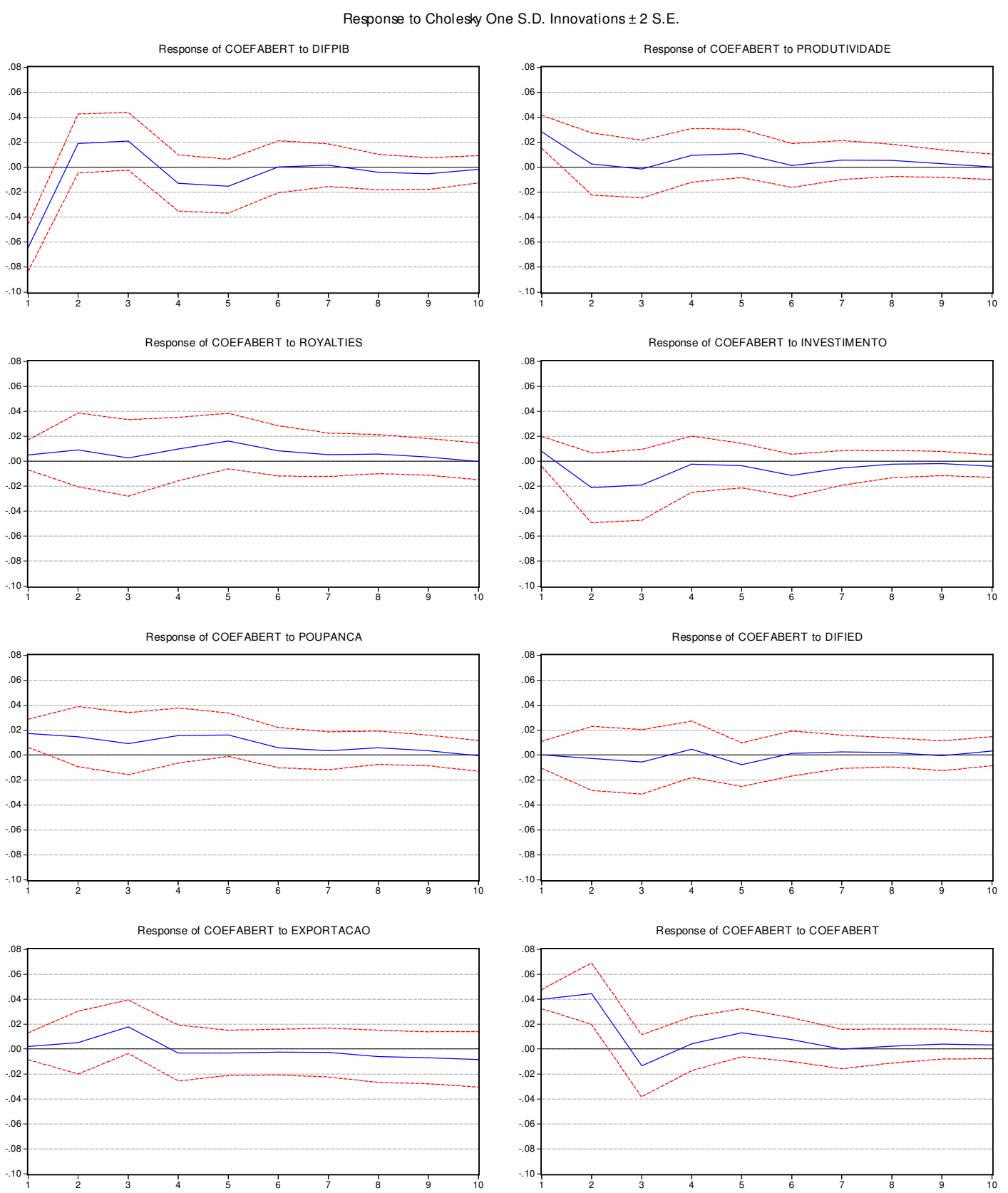

Gráfico 6.8 - Função de Resposta a Impulso para Coeficiente de Abertura 
De acordo com a figura 6.1, as curvas das Funções de Resposta a Impulso para o PIB revelam uma reação, no mesmo período (trimestre), a um impulso provocado no próprio indicador, e reações menos significativas nos dois períodos seguintes. O PIB ainda reage a impulso provocado pela abertura econômica e pelas exportações, em menor escala, no segundo e terceiro trimestres.

A figura 6.2 revela que a Produtividade reage a impulsos provocados pelo próprio indicador no primeiro período e tem reações em menor escala a impulsos provocados por inovação tecnológica (a partir do quarto período), investimento estrangeiro direto (no terceiro período) e exportações (a partir do sexto período).Os demais impulsos não são relevantes para esse indicador.

Para a inovação tecnológica, as curvas das Funções de Resposta ao Impulso, observadas na figura 6.3, revelam que esse indicador reage a impulsos procedentes do próprio indicador no primeiro período, e uma reação crescente a impulsos provocados pela exportação a partir do quarto período. Os demais impulsos não são significativos.

Segundo a figura 6.4, observa-se que o investimento interno reage ao impulso provocado pelo próprio indicador no primeiro período e, em menor escala, a impulsos provocados pelo crescimento econômico (PIB), produtividade e inovação tecnológica no segundo período.

As curvas de Funções de Resposta ao Impulso para Poupança revelam que, de acordo com a figura 6.5, esse indicador reage no mesmo período a impulsos provocados pelo próprio indicador, pelo investimento interno, pela inovação tecnológica e, em menor escala, pelo crescimento econômico. 
As reações do Investimento Estrangeiro Direto são apresentadas na figura 6.6. Observa-se que o Investimento Estrangeiro Direto reage significativamente a impulsos originados pelo próprio indicador. Os demais indicadores não provocam reações relevantes para o investimento estrangeiro direto.

De acordo com a figura 6.7, as curvas das Funções de Resposta ao Impulso revelam que as exportações reagem, no mesmo período, a impulsos provocados pelo próprio indicador, e apresentam reação, em menor escala (porém crescente), a partir do quinto período a impulsos originados da produtividade, inovação tecnológica e investimento estrangeiro direto.

A figura 6.8 revela que o coeficiente de abertura reage a impulsos provocados pelo próprio indicador e pelo crescimento econômico no primeiro período. Os demais impulsos não provocam reação significativa para o coeficiente de abertura. 


\subsection{ANÁLISE DE REGRESSÃO}

A análise entre crescimento e desenvolvimento ${ }^{10}$ econômico requer a utilização de dados anuais. Para o período analisado (1990-2005) tem-se 16 observações para cada variável. Assim, diante desta limitação de dados, decidiu-se utilizar o teste de aderência nãoparamétrico Kolmogorov-Smirnov.

\subsubsection{TESTE DE ADERÊNCIA NÃO-PARAMÉTRICO KOLMOGOROV-SMIRNOV}

O teste de Kolmogorov-Smirnov é o teste estatístico adequado para determinar se uma amostra é proveniente de uma população com distribuição contínua, ou seja, para observar a aderência das amostras a uma população com distribuição normal. De acordo com Campos (1983), em comparação com o teste Qui quadrado, o teste Kolmogorov-Smirnov é melhor para amostras pequenas (menor que 30 observações).

As tabelas de Kolmogorov-Smirnov foram corrigidas por Lillifors e é essa correção que aparece na determinação do $p$-value. O p-value é o menor valor do nível de significância que conduz à rejeição da hipótese nula. Assim, valores "grandes" do p-value conduzem à “aceitação" da hipótese nula e valores pequenos do $p$-value, à sua rejeição. O que se pretende testar é se a população tem distribuição normal (H0) ou não (H1).

Os resultados do teste Kolmogorov-Smirnov são apresentados na tabela 6.21. Para os dados anuais, rejeita-se a hipótese nula de distribuição normal para o indicador "Coeficiente de

\footnotetext{
${ }^{10}$ Os dados de desenvolvimento econômico não são publicados trimestralmente.
} 
Abertura Econômica”. Dessa forma, esse indicador é excluídos da análise de regressão. Para os demais indicadores, aceita-se a hipótese nula de que a população tem distribuição normal.

\begin{tabular}{lrrrrrrrr}
\hline & \multicolumn{4}{c}{ Most Extreme Differences } & \multicolumn{2}{c}{ Kolmogorov } & Asymp. Sig. & Exact Sig. \\
Variável & $\mathrm{N}$ & Absoluto & Positivo & Negativo & Smirnov Z & (2-tailed) & (2-tailed) \\
\hline PIB(2005) R $\$($ mil) & 16 & 0,115291 & 0,1136 & $-0,11529$ & 0,46116496 & 0,98355914 & 0,966917 \\
Produtividade & 16 & 0,154566 & 0,111278 & $-0,15457$ & 0,61826385 & 0,83921549 & 0,785411 \\
Royalties e Licenças - US $\$(\mathrm{mi})$ & 16 & 0,214451 & 0,214451 & $-0,16316$ & 0,85780396 & 0,45354128 & 0,397073 \\
Estudo PIA (anos) & 16 & 0,100838 & 0,100838 & $-0,09715$ & 0,40335188 & 0,99683665 & 0,991301 \\
Analfabetismo (\%) & 16 & 0,112379 & 0,112379 & $-0,11165$ & 0,44951766 & 0,98756091 & 0,973646 \\
Poupança / PIB (\%) & 16 & 0,094981 & 0,094981 & $-0,08099$ & 0,37992301 & 0,99871933 & 0,995781 \\
Investimento Interno / PIB (\%) & 16 & 0,108032 & 0,108032 & $-0,10352$ & 0,43212605 & 0,99216213 & 0,9819 \\
PIB per capita - (R \$ de 2005) & 16 & 0,18333 & 0,148831 & $-0,18333$ & 0,7333187 & 0,65528918 & 0,592274 \\
IDH do Brasil & 16 & 0,150453 & 0,150453 & $-0,10265$ & 0,60181009 & 0,86187696 & 0,811041 \\
Índice de Longevidade & 16 & 0,163853 & 0,146401 & $-0,16385$ & 0,65541196 & 0,7835829 & 0,724551 \\
Índice de Educação & 16 & 0,179422 & 0,133436 & $-0,17942$ & 0,71768924 & 0,68162197 & 0,618696 \\
Índice de Renda & 16 & 0,244617 & 0,244617 & $-0,23253$ & 0,97846732 & 0,2938003 & 0,249875 \\
IED/PIB & 16 & 0,172393 & 0,172393 & $-0,14087$ & 0,68957186 & 0,72851796 & 0,666605 \\
Coeficiente de Abert. Econômica & 16 & 0,259595 & 0,259595 & $-0,14964$ & 1,03838162 & 0,23110644 & 0,193631 \\
Coeficiente de Exportação & 16 & 0,237072 & 0,237072 & $-0,14415$ & 0,94828679 & 0,32959348 & 0,282351 \\
\hline
\end{tabular}

Tabela 6.21 - Teste Kolmogorov-Smirnov

De acordo com a tabela 6.21, o indicador Coeficiente de Abertura Econômica deve ser excluído da análise por não apresentar uma distribuição normal. O passo seguinte é fazer a análise de regressão para avaliar a relação entre crescimento, desenvolvimento e fluxos internacionais. Alguns dos indicadores apresentam informações que já estão compostas em outros indicadores. Esse é o caso do IDH, que tem seu cálculo baseado nos índices de longevidade, educação e renda, e da produtividade que, segundo alguns autores, é derivada de capital humano, capital físico e progresso tecnológico.

Assim, para compreender o grau de importância na composição dos indicadores IDH e produtividade, a análise de regressão será feita para esses indicadores, além de crescimento e desenvolvimento econômico. 


\subsubsection{ANÁLISE DE REGRESSÃO - PRODUTIVIDADE}

\begin{tabular}{|c|c|c|c|c|c|}
\hline \multirow[t]{2}{*}{ Model } & \multicolumn{2}{|c|}{ Coeficientes Não Padronizados } & \multirow{2}{*}{$\begin{array}{c}\text { Coeficientes Padronizados } \\
\text { Beta }\end{array}$} & \multirow{2}{*}{$\mathrm{t}$} & \multirow{2}{*}{$\begin{array}{c}\text { Sig. } \\
\text { Erro Padrão }\end{array}$} \\
\hline & $\mathrm{B}$ & Erro Padrão & & & \\
\hline (Constant) & $-140,829$ & 28,332 & & $-4,971$ &, 000 \\
\hline Royalties (tecnologia) & $-38,498$ & 39,555 &,- 114 &,- 973 & ,351 \\
\hline Estudo PIA (anos) & 34,188 & 3,292 &, 776 & 10,385 & 000 \\
\hline Investimento Interno & 3,586 & 1,221 & ,115 & 2,938 & 013 \\
\hline Inv. Estrangeiro. Direto & 2,445 & 1,362 & 149 & 1,795 & 100 \\
\hline $\mathrm{R}$ & ,992(a) & & & & \\
\hline R Quadrado & ,984 & & & & \\
\hline R Quadrado Ajustado & ,978 & & & & \\
\hline Erro Padrão da Estimativa & 4,367 & & & & \\
\hline
\end{tabular}

Tabela 6.22 -Modelo de Regressão para Produtividade

Segundo a revisão bibliográfica, tem-se que a produtividade é derivada do capital humano, capital físico e o progresso tecnológico. Conforme visto nas análises de causalidade de Granger, o investimento estrangeiro direto também afeta a produtividade. Assim, a análise de regressão da produtividade revelou que o capital humano influi mais fortemente no aumento da produtividade. A análise também revelou que o investimento externo e o progresso tecnológico também influenciam o indicador, porém em menor escala.

O indicador de progresso tecnológico apresenta valor negativo nos coeficientes padronizados, pois a série histórica apresenta saldo negativo no indicador royalties e licenças, o que significa que o país pagou mais por tecnologia do que recebeu. 


\subsubsection{ANÁLISE DE REGRESSÃO - ÍNDICE DE DESENVOLVIMENTO HUMANO}

\begin{tabular}{|c|c|c|c|c|c|}
\hline & $\begin{array}{c}\text { Coeficientes } \\
\text { B }\end{array}$ & $\begin{array}{l}\text { O Padronizados } \\
\text { Erro Padrão }\end{array}$ & $\begin{array}{c}\text { Coeficientes Padronizados } \\
\text { Beta }\end{array}$ & $\begin{array}{l}\mathrm{t} \\
\mathrm{B}\end{array}$ & $\begin{array}{c}\text { Sig. } \\
\text { Erro Padrão }\end{array}$ \\
\hline (Constant) &,- 001 & ,019 & &,- 037 &, 971 \\
\hline Índice de Longevidade & ,326 & ,027 & ,416 & 12,149 &, 000 \\
\hline Índice de Educação & ,338 & ,010 & 1,224 & 32,374 & ,000 \\
\hline Índice de Renda & ,336 &, 007 & 1,504 & 48,971 & ,000 \\
\hline $\mathrm{R}$ & ,998(a) & & & & \\
\hline R Quadrado & ,996 & & & & \\
\hline R Quadrado Ajustado & ,995 & & & & \\
\hline Erro Padrão da Estimativa & ,001793 & & & & \\
\hline
\end{tabular}

Tabela 6.23 - Modelo de Regressão para IDH

Segundo Souza (2005) e Veiga (2005), o Índice de Desenvolvimento Humano pode substituir os outros indicadores para mensurar desenvolvimento. O IDH é composto por três índices: longevidade, educação e renda. A análise de regressão revelou que, na composição do IDH, os indicadores que mais fortemente explicam a evolução do índice são os índices de educação e renda.

Essa relação vem corroborar duas observações. A primeira observação é que a educação gera desenvolvimento. $\mathrm{Na}$ análise de regressão anterior (produtividade), o indicador capital humano, que avalia educação, apresentou grande importância na composição e explicação da evolução da produtividade. A segunda observação vem reforçar a idéia de que para haver desenvolvimento é necessário haver crescimento econômico. A importância do índice renda reflete a necessidade de crescimento econômico e partilha da renda. 


\subsubsection{ANÁLISE DE REGRESSÃO - CRESCIMENTO ECONÔMICO}

\begin{tabular}{|c|c|c|c|c|c|}
\hline & $\begin{array}{c}\text { Coeficientes Nã } \\
\text { B }\end{array}$ & $\begin{array}{c}\text { o Padronizados } \\
\text { Erro Padrão }\end{array}$ & $\begin{array}{c}\text { Coeficientes } \\
\text { Padronizados } \\
\text { Beta }\end{array}$ & $\begin{array}{l}\mathrm{t} \\
\mathrm{B}\end{array}$ & $\begin{array}{c}\text { Sig. } \\
\text { Erro Padrão }\end{array}$ \\
\hline (Constant) & 403642237,094 & 311674633,242 & & 1,295 & 220 \\
\hline Produtividade (Indústria) & 6351460,724 & 455972,573 & 955 & 13,929 & ,000 \\
\hline Poupança / PIB & 9597660,755 & 6236498,826 & ,104 & 1,539 &, 150 \\
\hline Investimento Interno / PIB & 9125723,448 & 14260490,263 & ,044 & ,640 &, 534 \\
\hline $\mathrm{R}$ &, $972(a)$ & & & & \\
\hline R Quadrado & ,945 & & & & \\
\hline R Quadrado Ajustado & ,931 & & & & \\
\hline Erro Padrão da Estimativa & 51043079,0943 & & & & \\
\hline
\end{tabular}

Tabela 6.24 - Modelo de Regressão para Crescimento Econômico

O crescimento econômico é composto por uma combinação de vários fatores. De acordo com alguns dos fatores analisados neste estudo, o crescimento econômico é derivado da produtividade, poupança (revertida em investimento) e investimento interno, direcionado à modernização e infra-estrutura, melhorando a produtividade.

A análise de regressão do crescimento econômico, medido pelo PIB (2005), indica que a produtividade explica melhor o crescimento desse indicador. A produtividade, como vista nas regressões anteriores, é melhor explicada por investimentos em capital humano e progresso tecnológico. 


\subsubsection{ANÁLISE DE REGRESSÃO - DESENVOLVIMENTO ECONÔMICO}

\begin{tabular}{|c|c|c|c|c|c|}
\hline & $\begin{array}{l}\text { Coeficientes Nã } \\
\text { B }\end{array}$ & $\begin{array}{l}\text { Padronizados } \\
\text { Erro Padrão }\end{array}$ & $\begin{array}{c}\text { Coeficientes Padronizados } \\
\text { Beta }\end{array}$ & $\begin{array}{l}\mathrm{t} \\
\mathrm{B}\end{array}$ & $\begin{array}{c}\text { Sig. } \\
\text { Erro Padrão }\end{array}$ \\
\hline (Constant) & $-1216,429$ & 234,875 & & $-5,179$ & ,001 \\
\hline Produtividade (Indústria) &, 068 & ,328 &, 076 & ,208 & ,840 \\
\hline Índice de Gini & 1332,164 & 333,933 & ,614 & 3,989 & ,003 \\
\hline Índice de Longevidade & 372,995 & 307,774 & , 451 & 1,212 & ,256 \\
\hline Índice de Educação & 90,742 & 67,765 & ,311 & 1,339 & ,213 \\
\hline Índice de Renda & 102,811 & 52,692 & ,437 & 1,951 & 083 \\
\hline PIB per capita $(\mathrm{R} \$ 2005)$ &, 032 & ,026 & 620 & 1,263 & ,238 \\
\hline $\begin{array}{l}\text { R } \\
\text { R Quadrado } \\
\text { R Quadrado Ajustado } \\
\text { Erro Padrão da Estimativa }\end{array}$ & $\begin{array}{r}, 960(a) \\
, 921 \\
, 869 \\
9,4636134\end{array}$ & & & & \\
\hline \multicolumn{6}{|c|}{$\begin{array}{l}\text { a Preditores : (Constant), PIB per capita - (R\$ de 2005), Índice de Gini, Índice de Renda, Índice de Educação, } \\
\text { Produtividade (Indústria), Índice de Longevidade } \\
\text { b Variável Dependente: Rendimento Domiciliar per capita }\end{array}$} \\
\hline
\end{tabular}

Tabela 6.25 - Modelo de Regressão para Desenvolvimento Econômico

O desenvolvimento econômico pode ser medido por vários indicadores como IDH, PIB per capita e renda per capita. No entanto, de acordo com Hoffman (1998), o rendimento domiciliar per capita também é uma medida de desenvolvimento econômico e é a melhor alternativa para analisar as diferenças de nível de vida ou pobreza.

Assim, a análise de regressão para desenvolvimento econômico, utilizando a variável dependente rendimento domiciliar per capita, indicou que os fatores que melhor explicam a evolução desse indicador são o PIB per capita, que mensura o crescimento econômico relativo a cada indivíduo, e a concentração de renda (índice de Gini). Renda, Educação e Longevidade também foram considerados significativos. 


\section{CONSIDERAÇÕES FINAIS}

O presente estudo buscou analisar relações de causalidade entre crescimento, desenvolvimento econômico e fluxos de bens e capitais externos. Para isso foram realizados testes estatísticos para mensurar e constatar a relação de causalidade. A impossibilidade de realizar os testes de causalidade de Granger para os indicadores com periodicidade anual (com poucas observações), direcionou parte do estudo de causalidade para a análise de regressão.

Os resultados do teste de causalidade de Granger revelaram indícios de que o crescimento econômico foi causado pelo investimento interno, ou seja, pelo investimento fixo das empresas (formação bruta de capital fixo) e pela variação de estoques de bens adquiridos para uso futuro. Os resultados também sinalizaram que o investimento interno foi causado pela poupança. Essas duas constatações corroboram os conceitos apresentados por Marshall (1996), Bovespa (2000), Lopes e Vasconcellos (2000), Stiglitz e Walsh (2003) e Mankiw (2005) de que o estoque de capital pode ser influenciado pela poupança (um aumento na taxa de poupança eleva os investimentos e, em longo prazo, o estoque de capital também será elevado) e que maiores níveis de investimento em relação ao PIB podem resultar em mais capital por trabalhador, proporcionando crescimento e desenvolvimento econômico.

Outro fator que apresentou relação de bicausalidade com o crescimento econômico foi a abertura econômica (medida pelo Coeficiente de Abertura). Os resultados indicaram que a abertura econômica causa crescimento econômico e que as conseqüências desse crescimento podem gerar maior produtividade e competitividade, aumentando o grau de interação do país com o exterior. Os resultados da decomposição da variância para o PIB sugerem que, em longo prazo, a variância do crescimento econômico (PIB) pode ser explicada pela variância da 
integração comercial (Coeficiente de Abertura) e pelas exportações. A decomposição da variância do Coeficiente de Abertura, por sua vez, sinalizou que essa variável por ser explicada, em longo prazo, pelo crescimento econômico (PIB), produtividade, investimento interno e poupança.

O teste de causalidade de Granger também indicou, com ressalvas, que a taxa de poupança causa aumento de produtividade e que a produtividade eleva os investimentos internos. Essa afirmação também é defendida por Smith (1996) ao sustentar que o crescimento da produtividade permite o crescimento do estoque de capital, promovendo crescimento. Apesar de o teste $\mathrm{F}$ aceitar essas relações de causalidade, as ressalvas se dão pela probabilidade de não rejeitar a hipótese nula de não-causalidade para poupança $(13,77 \%)$ e para investimento $(10,43 \%)$. A análise de regressão confirmou a hipótese de que o crescimento econômico é fortemente relacionada à produtividade.

A produtividade, no entanto, é derivada de vários fatores. Para Mankiw (2005), a produtividade é influenciada pelo progresso tecnológico, capital humano e capital físico. Os testes de causalidade indicaram que a produtividade é causada pelo investimento em tecnologia e investimento estrangeiro direto, este último direcionado principalmente à modernização das indústrias para aumento de competitividade. Essa afirmação foi reforçada pela análise de decomposição da variância da produtividade, que sugeriu que a variância da produtividade pode ser explicada pela inovação tecnológica e pelos investimentos estrangeiros diretos.

Os dados referentes a capital humano, devido à periodicidade, não puderam ser testados pelo teste de Granger. Assim, para avaliar o efeito do capital humano foi realizado o teste de 
regressão, que revelou que o capital humano, medido no teste pelo número de anos de estudo da população em idade ativa, parece ter forte influência no comportamento da produtividade. A única constatação que não refletiu os conceitos apontados pela revisão teórica é a de que os investimentos internos não causam, no sentido de Granger, aumento de produtividade.

A produtividade, por sua vez, apresentou relação de bicausalidade com exportações. Isso parece indicar que o aumento de produtividade tende a gerar maior competitividade para as empresas, o que pode se refletir em produtos com maior valor agregado, mais qualidade ou preços mais baixos. Com os produtos em melhores condições de concorrência, as empresas tendem a exportar mais. Por outro lado, as exportações refletem a necessidade de as empresas se adequarem às necessidades do mercado internacional, ou seja, se modernizarem. Essa afirmação também foi ratificada pela decomposição da variância da inovação tecnológica que, no longo prazo, teve sua variância explicada pelas exportações.

As exportações, no sentido Granger, são causadas pelo investimento estrangeiro direto. Os resultados sugeriram que o investimento estrangeiro, direcionado à modernização das indústrias e aumento da produtividade, contribuiu para o aumento da competitividade, proporcionando aumento nas exportações. É importante observar que, apesar de fazerem parte da equação do PIB, as exportações não causam crescimento econômico, no sentido de Granger. Isso pode ser explicado por dois fatores. O primeiro é que a série exportações foi defasada em relação ao PIB, de forma que uma série futura não pode causar o presente. $\mathrm{O}$ segundo fator levou em consideração a participação das exportações no PIB, uma média de 11,15\% no período. Apesar do crescimento das exportações, especialmente a partir de 1999, a participação das exportações no PIB ainda é baixa. Com uma participação pequena na composição do PIB, a hipótese nula de que as exportações não causam, no sentido Granger, 
crescimento econômico, não foi rejeitada. Por outro lado, a relação de causalidade no sentido contrário indicou que o crescimento econômico causa aumento de exportações.

De acordo com a decomposição da variância para exportações, a variância desse indicador parece ser explicada, em longo prazo, pela produtividade, investimentos estrangeiros diretos, inovação tecnológica e poupança. Isso ocorre, pois, com o crescimento econômico, a taxa de poupança tende a aumentar, proporcionando aumento nos investimentos internos e aumento de produtividade. $\mathrm{O}$ aumento de competitividade, gerado nesse processo, pode elevar as exportações.

A revisão teórica indicou que tanto o IDH quanto o rendimento domiciliar per capita são os melhores indicadores para se avaliar desenvolvimento econômico. Assim, duas análises buscam identificar as relações entre crescimento e desenvolvimento econômico. O IDH é composto por três índices. A análise de regressão desse indicador revelou que o índice de renda é o mais representativo na constituição do IDH, seguido pelo índice de educação.

Os dados parecem sinalizar que o primeiro aspecto a ser considerado para promover o desenvolvimento é a renda. $\mathrm{O}$ aumento de renda é uma consequiência do crescimento econômico. Partindo do princípio de que quanto mais rico for o país, melhores tendem a ser as condições de vida para a população. Assim, pode-se considerar que o crescimento econômico (e a geração de riqueza), não só esta atrelado, pode promover desenvolvimento. O índice de educação também parece ser representativo como meio de promoção do desenvolvimento econômico e social. A melhoria nesse indicador, conforme discutido anteriormente, e assim como o capital humano, pode se refletir em melhores níveis de produtividade e conseqüente aumento de competitividade, exportações e crescimento econômico. 
O segundo indicador sugerido foi o rendimento domiciliar per capita. A análise de regressão, utilizando esse indicador como variável dependente, indicou que a renda (avaliada pelo PIB per capita e o índice de renda do IDH) e a concentração de renda (medida pelo coeficiente de Gini) são os indicadores mais representativos para melhorar o desenvolvimento econômico. Isso sugere que não adianta apenas o país crescer. É necessário também reduzir a concentração de renda para promover desenvolvimento. Outros indicadores como longevidade, educação e produtividade se mostraram menos representativos na composição do indicador.

Assim, conclui-se que para haver desenvolvimento é necessário crescimento econômico. Contudo, o crescimento econômico por si não é capaz de gerar melhores condições se não houver maior distribuição de renda. Caso a concentração de renda continue alta, os benefícios do crescimento econômico não atingirão a população. Outro ponto importante é que o crescimento econômico parece depender da taxa de poupança, dos investimentos internos e da produtividade. Conforme visto, os investimentos em inovação tecnológica e educação, visando aumento de produtividade, são essenciais para o crescimento econômico.

\subsection{SUGESTÃO PARA ESTUDOS FUTUROS}

O crescimento econômico é proveniente de uma série de fatores combinados. Uma vez que crescimento econômico e a abertura econômica estão relacionados, o estudo da influência do câmbio no crescimento econômico é pertinente. Outras abordagens importantes são as análises sobre o impacto da taxa de juros nos investimentos e a questão dos gastos do governo, relacionados ao crescimento econômico. 


\section{REFERÊNCIAS*}

ABRAMOVAY, R. Desenvolvimento e Instituições: a importância da explicação histórica. in ARBIX, G.; ZILBOVICIUS, M.; ABRAMOVAY, R. Razões e Ficções para o Desenvolvimento. Organizadores: ARBIX; ZILBOVICIUS; ABRAMOVAY, vários autores, São Paulo, Editora UNESP; EDUSP, 2001

ADELMAN, I. Beyond export-led growth. World Development, p. 937-49, 1984

AFXENTIOU, P. C.; SERLETIS, A. Exports and GNP Causality in the industrial countries: 1950-1985, Kyklos, (Mai): 167-79, 1991

AHMAD, J. e HARNHIRUN, S. Cointegration and causality between exports and economic growth: evidence from the ASEAN countries. The Canadian Journal of Economics, p.413-416, 1996

AITKEN, B; HANSON, G. HARRISON, A. Spillovers, Foreign Investment and Export Behavior, Journal of International Economics, 1997

ALMEIDA, P. R. A globalização e o desenvolvimento: vantagens e desvantagens de um processo indomável. in CHEREM, M. T. C. S.; DI SENA JÚNIOR, R. (Organizadores) Comércio Internacional e Desenvolvimento: uma perspectiva brasileira. São Paulo, Editora Saraiva, 2004

ALMEIDA, P. R. Propriedade intelectual: os novos desafios para a América Latina. Estudos Avançados, Mai/Ago, vol.5, no.12, p.187-203, 1991

AL-YOUSIF, Y. K. Exports and economic growth: Some empirical evidence from the Arab Gulfcountries, Applied Economics, 29, 6 (Jun): 693-97, 1997

ARAÚJO JR., J. T. Concorrência, Competitividade e Política Econômica. in BAUMANN, R. O Brasil e a economia global. Renato Baumann (org.), Rio de Janeiro, Elsevier: SOBEET, 1996

ABNT ASSOCIAÇÃO BRASILEIRA DE NORMAS E TÉCNICAS. NBR 6023: informação e documentação: referências: elaboração. Rio de Janeiro, 2002

BALASSA, B. Exports and economic growth: Further evidence, Journal of Development Economics, (Jun): 181-89, 1978

BALASSA, B. Exports, policy choices, and economic growth in developing countries after the 1973 oil shock, Journal of Development Economics, (Jun): 23-35, 1985

BALASSA, B. The process of industrial development and alternative development stategies, Princeton Essays in International Finance, Princeton, NJ: Princeton University, Department of Economics, (Dez), 1980

BARROS, R. P.; MENDONÇA, R. O impacto do crescimento econômico e de reduções no grau de desigualdade sobre a pobreza. Novos Estudos CEBRAP, n. 51, p. 107-122, 1998

\footnotetext{
* De acordo com ASSOCIAÇÃO BRASILEIRA DE NORMAS E TÉCNICAS. NBR 6023: informação e documentação: referências: elaboração. Rio de Janeiro, 2002
} 
BATISTA JR. P. N. Mitos da “globalização”. Revista Estudos Avançados, São Paulo, USP, 125-86, 1998

BAUMANN, R. O Brasil e a economia global. Renato Baumann (org.), Rio de Janeiro, Elsevier: SOBEET, 1996

BAUMANN, R.; CANUTO, O.; GONÇALVES, R. Economia Internacional: Teoria e Experiência Brasileira. Rio de Janeiro: Elsevier, 2004

BEGUM, S.; SHAMSUDDIN, A. F. M. Exports and economic growth in Bangladesh, Journal of Development Studies, (Out): 89-114, 1998

BEN-DAVID, D.; KIMHI, A. Trade and the Rate of Income Convergence. NBER Working Papers 7642, Abr, 2000

BERTELlA, M. A.; LIMA, G. T. Investimento Direto Externo, Acumulação de Capital Produtivo e Distribuição de Renda: Uma abordagem pós-keynesiana. Revista de Economia Política, Vol 25, n. 2, pp. 74-95, abril/junho 2005

BHAGWATI, J. Immiserizing growth: a geometric note. Review of Economics Studies, 201-5, 1958

BHAGWATI, J. A Economia em países subdesenvolvidos. Tradução de Heitor Pinto de Moura Filho e Norma Paraíso Nogueira, Editora Zahar, Rio de Janeiro, 1975

BHALLA, S. Imagine there's no country: poverty, inequity and growth in the era of globalization. Washington, Institute for International Economics, 2002

BIELSCHOWSKY, R.; STUMPO, G. A internacionalização da Indústria brasileira: números e reflexões depois de alguns anos de abertura in BAUMANN, R.. O Brasil e a economia global. Renato Baumann (org.), Rio de Janeiro, Elsevier: SOBEET, 1996

BLANCO, M.; CLUSA, M.; MONASTIRSKY, N.; PERATTA, C. Hume en oposición a las teorías mercantilistas: la importância de sus críticas. 2004 (disponível em http://www.cema.edu.ar/ jms/cursos/historia del_pensamiento economico/curso_2004/2004 David_HumeF.pdf, acesso em 21/7/2006, às 20:00)

BLEANEY, M. Trade reform, macroeconomic performance and export growth in ten Latin American countries, 1979-95. Working Papers. Center for Research in Economic Development International Trade, University of Nottingham, 1997

BLECKER, R. Taming global finance. Washington, D.C. : Economic Policy Institute, 1999

BLOMSTRÖM, M. Transnational Corporations and Manufacturing Exports from Developing Countries, United Nations Center on Transnational Corporations, 1990

BOVESPA O Mercado de Capitais - Sua importância para o desenvolvimento e os entraves com que se defronta no Brasil, 2000 (disponível em www.bovespa.com.br/pdf/relatorio2.pdf , acesso em 27/5/2006, às 17:30)

BRESSER-PEREIRA, L. C. e NAKANO, Y. Uma estratégia de desenvolvimento com estabilidade. Revista de Economia Política, p. 146-177, 2002 
BRUNI, A. L. Globalização financeira, eficiência informal e custo de capital: uma análise das emissões de ADRs brasileiros no período 1992-2001. Tese de Doutorado, São Paulo, FEA USP, 2002

CALVO, G. A. Crises de Balanços de Pagamentos nos Mercados Emergentes: Grandes Fluxos de Entrada de Capitais e Governos Soberanos. in KRUGMAN, Paul (Ed) - Crises Monetárias. São Paulo: Makron Books - 2001

CAMPBELL, J. Y.; PERRON, P. Pitfalls and opportunities: What Macroeconomists should know about unit roots. NBER Macroeconomist, Cambridge MIT Press, 1991

CAMPOS, H. Estatística experimental não-paramétrica. 4. Ed. Piracicaba: Departamento de Matemática e Estatística - ESALQ, 1983

CANUTO, O. Padrões de especialização, hiatos tecnológicos e crescimento com restrições de divisas. Revista de Economia Política, (71), p. 5-15, 1998

CARNEIRO, F. G. A Metodologia dos Testes de Causalidade em Economia. Brasília: Departamento de Economia, UnB, Série Textos Didáticos n. 20, 1997

CAVALCANTI, M.; FRISCHTAK, C. R. Crescimento Econômico, Balança Comercial e a Relação Câmbio-Investimento. Textos para Discussão, IPEA, 2001

CAVES, R. E.; FRANKEL, J. A.; JONES, R. W. Economia Internacional: Comércio e Transações Globais. Tradução da $8^{a}$ Edição Internacional - Cecília C. Bartalotti e Célio Knipel Moreira, São Paulo, Editora Saraiva, 2001

CERVO, A. L.; BERVIAN, P. A. Metodologia Científica. 4a Edição, São Paulo, Makron Books, 1996

CERVO, Amado Luiz; BERVIAN, P. Metodologia Científica: para uso dos estudantes universitários. $2^{\text {a }}$ Edição, São Paulo, McGraw Hill do Brasil, 1978

CHEREM, M.; DI SENA JÚNIOR, R. Comércio Internacional e Desenvolvimento: uma perspectiva brasileira. São Paulo, Editora Saraiva, 2004

CHESNAIS, F. A globalização e o curso do capitalismo de fim de século. Campinas. Economia e Sociedade n. 5, 1995

CHESNAIS, F. A mundialização do capital. São Paulo, Xamã, 1996

CHESNAIS, F. A mundialização financeira: gênese, riscos e custos. Coordenado por François Chesnais, Editora Xamã, 1998

CHOW, P. C. Y. Causality between export growth and industrial development:

Empirical evidence from the NICs, Journal of Development Economics, 26, 1 (Jun): 55-63, 1987

CHOW, P.C.Y. Causality between export growth and industrial development: empirical evidence from the NICs. Journal of Development Economics, 26, p. 55-63, 1987

CHUDNOVSKY, D; LOPEZ Uma visión macroeconómica de los impactos de la integración regional sobre las inversiones inter e intraregionales: el caso el Mercosur. Red Intal, abril, mimeo, 2002 
CINTRA, M. A. M.; PRATES, D. M. Os fluxos de capitais internacionais para o Brasil desde os anos 90 in: Seminário Internacional Controle de Capitais e Alternativas Econômicas, 2004, São Paulo, 2004

COLMAN, D.; NIXSON, F. Desenvolvimento Econômico, uma perspectiva moderna. Editora Campus/EDUSP, 1981.

COLOMBATTO, E. An analysis of exports and growth, Kyklos, 43, 4 (November): 579-97, 1990

CORAZZA, G. A inserção do Brasil na Globalização Financeira: Uma análise introdutória da década de 1990. in Congrès International Marx, 2004, Paris, 2004 (disponível em http://netx.u-paris10.fr/actuelmarx/m4corra.htm, acesso em 26/04/2006, às 15:00)

CORDEIRO, M. P.; SANTOS, S. A.; OLIVEIRA, J. F. Economia para Administradores. Organizador: Jayr Figueiredo Oliveira, São Paulo, Saraiva, 2005

COUTINHO, L. A fragilidade do Brasil em face da globalização in Baumann, R. O Brasil e a economia global. Rio de Janeiro, Editora Campus, SOBEE II, 1996, p. 219-237

DALCERO, P. L. Globalização financeira e volatilidade de capitais: a busca de uma alternativa racionalista Revista Brasileira de Política Internacional, vol. 40, n. ${ }^{\circ}$ 2, Brasília, IBRI - Instituto Brasileiro de Relações Internacionais, pp. 131 a 143, 1997

DARRAT, A. F. Are exports an engine of growth? Another look at the evidence. Applied Economics, 19, 2 (Fev): 277-83, 1987

DAVIDSON, R.; MACKINNON, J. G. Estimation and Inference in Econometrics. Oxford Economic Press, 1993

DI SENA JUNIOR, R. Crescimento econômico e desigualdade à luz do comércio internacional. in CHEREM, M. T. C. S.; DI SENA JÚNIOR, R. (Organizadores) Comércio Internacional e Desenvolvimento: uma perspectiva brasileira. São Paulo, Editora Saraiva, 2004

DICKEY, D. A.; FULLER, W. A Distribution of estimators for autoregressive time series with a unit root. Journal of the American Statistical Association, v.74, n.366, p.427-431, 1979

DICKEY, D. A.; FULLER, W. A. A likelihood ratio statistics for autoregressive time series with unit root. Econometrica, V. 49, n.4, p1057-1072, 1981

DURLAUF, S. N. Vector Autoregressions - Lecture Notes 6. Economics, 712, 2005

EASTERLY, W.; LOYAZA, N; MONTIEL, P. Has Latin America's post-reform growth been disappointing? Journal of International Economics. 43(2): 287-311, 1997

EDWARDS, S. Openness, productivity, and growth: what do we really know? Economic Journal. 108(1): 383-98, 1998

EDWARDS, S. Trade orientation, distortions, and growth in developing countries. Journal of Development Economics. 39(1): 31-57, 1992 
EDWARDS, S. Trade policy, exchange rates and growth. NBER Working papers n.4511. Cambridge, Massachusetts, 1993

EHLERS, R. S. Análise de Séries Temporais. Universidade Federal do Paraná, 2003.

EMERY, R. F. The relation of exports and economic growth. Kyklos, 20, 2 (Mai): 470-86, 1967

ENGLE, R. F.; GRANGER, C. W. J. Cointegration and error correction: representation, estimation and testing. Econometrica, 55, 251-76, 1987

FAJANA, O. Trade and growth: The Nigerian experience, World Development, (Jan): 7378,1979

FASANO FILHO, U. A expansão das exportações e o crescimento econômico: o caso do Brasil, 1969-84. Revista Brasileira de Economia, 42(1), p. 73-81, 1988

FEDER, G. On exports and economic growth. Journal of Development Economics, 12, 2 , (Fev/Abr): 59-73, 1983

FELTRIN, L. Mudanças estruturais na inserção brasileira no comércio internacional de bens de capital: 1991-2000. Perspectiva Econômica, 75-99, jul/dez 2005

FIGUEROA, L.; LETELIER-SAAVEDRA, L. Exportaciones, Orientación al Comercio y Crecimiento: Un Enfoque de Cointegración, Cuadernos de Economía (Pontificia Universidad Católica de Chile), 31, 94 (December): 401-21, 1994

FINDLAY, C.; WATSON. A. Economic growth and trade dependence in China. DP 96/5, Chinese Economies Research Centre, University of Adelaide, 1996

FIORI, J. L. A globalização e a novíssima dependência. (Texto para discussão), Rio de Janeiro, UFRJ, 1995

FOSU, A. K. Exports and economic growth: The African case. World Development, 18, 6 (June): 831-35, 1990

FRANKEL, J.; ROMER, D. Does trade causes growth? American Economic Review. 89(3): 379-99, 1999

FREITAS, C. A.; BACHA, J. C. Contribuição do Capital Humano para o Crescimento da Agropecuária Brasileira. Período de 1970-1996. RBE, Rio de Janeiro 58(4) 533-557 outdez, 2004

FRENKEL, R. Capital market liberalization and economic performance in Latin America. Working papers Series III, n.1. Cepal, New School, 1998

FRITSCH, W. in SMITH, A. A riqueza das nações: Investigação sobre sua natureza e suas causas. Volume I, Tradução de Luiz João Baraúna, Coleção os Economistas, Editora Nova Cultural, 1996

FULLER, W. A. Introduction to statistical time series. New York, John Wiley, p.424, 1976

FURTADO, C. Globalização das estruturas econômicas e identidade nacional. Revista Estudos Avançados, USP: São Paulo, 6(16), 55-64, 1992 
GENRO, T. Os desafios da Tragédia. Revista Estudos Avançados, USP: São Paulo, 14(38), 222-234, 2000

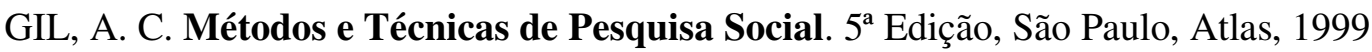

GILES, J. A. e WILLIAMS, C. L. Export-led growth: a survey of the empirical literature and some noncausality results. University of Victoria, Econometrics Working Paper, Jan, 2000. (disponível em: http://web.uvic.ca/econ/ewp0001.pdf , acesso em 18/05/2006, às 15:00)

GITMAN, L. J. Princípios de Administração Financeira $10^{a}$ Edição, Tradução Técnica Antonio Zoratto Sanvicente, São Paulo, Pearson Addison Wesley, 2004

GOLDSTEIN, L. Repensando a Dependência. Rio de Janeiro: Paz e Terra, 1995

GONÇALVES, R. Globalização Financeira, Liberalização Cambial e Vulnerabilidade Externa da Economia Brasileira. in BAUMANN, R. O Brasil e a economia global. Renato Baumann (org.), Rio de Janeiro, Elsevier: SOBEET, 1996

GONÇALVES, R.; BAUMANN, R.; PRADO, L. C.; CANUTO, O. A Nova Economia Internacional - Uma perspectiva Brasileira. Rio de Janeiro, Editora Campus, 1998

GORENDER, J. Estratégias dos Estados Nacionais Diante do Processo de Globalização. Revista Estudos Avançados, USP: São Paulo, n.25, 1995.

GÖRG, H; STROBL, E. Multinational Companies and Productivity Spillovers: A MetaAnalisys with a Test for Publication Bias. Research Paper 17, Centre for Research on Globalisation and Labour Markets, University of Nottingham, 2000

GOVINDARAJAN, V. ; GUPTA A. L. Traçando um rumo no mundo globalizado. Gazeta Mercantil, Série Global Business, número 1, pp. 03-05, 07/07/1998, 1998

GRANGER, C. W. J. Investigating causal relations by economic models and crossspectral methods. Econometria, 37, p. 424-38, 1969

GREENAWAY, D.; SAPSFORD, D. What does liberalisation do for exports and growth. Weltwirtschaffliches Archiv, 130, 1: 152-74, 1994

GREMAUD, A. P., Manual de Economia. Organizadores: PINHO, D. B.; VASCONCELOS, M. A. S., $4^{\text {a }}$ Edição, São Paulo, Saraiva, 2003

GREMAUD, A. P.; VASCONCELLOS, M. A. S.; TONETO JR., R. Economia Brasileira Contemporânea. $4^{a}$ Edição, São Paulo: Atlas, 2002

GREMAUD, A. P.; VASCONCELLOS, M. A. S.; TONETO JR., R. Economia Brasileira

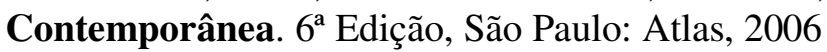

GRÔPPO, G. S. Causalidade das variáveis macroeconômicas sobre o ibovespa. Dissertação de Mestrado, Piracicaba, ESALQ-USP, 2004

GROSMAN, G.; HELPMAN, E. Comparative advantage and long-run growth. American Economic Review. 80(4): 796-815, 1990

GUJARATI, D. N. Basic Econometris. $3^{\text {rd }}$ Edition, MCGraw-Hill, Londres, 1995

HARRISON, A.; HANSON, G. Who gains from trade reform? Some remaining puzzles. NBER Working Papers n.6915, 1999 
HATEMI-J, A.; IRANDOUST, M. Export performance and economic growth causality: an empirical analysis. Atlantic Economic Journal, 28(4), p. 412-426, 2000.

HEITGER, B. Import protection and export performance: Their Impact on Economic Growth, 249-61, 1987

HELLEINER, G. K. Trade, trade policy, and industrialization., 1996

HELLER, P. S.; PORTER, R. C. Exports and growth: An empirical re-investigation, Journal of Development Economics, 5, 2 (Jun): 191-93, 1978

HENRIQUES, I.; SADORSKY, P. Export-led growth or growth-driven exports? The Canadian Case, Canadian Journal of Economics, 29, 3 (Ago): 541-55, 1996

HILL, R. C.; GRIFFITHS, W. E.; JUDGE, G. Econometria. Tradução Alfredo Alves de Faria, $2^{\text {a }}$ Edição, São Paulo, Editora Saraiva, 2006

HIRAKUTA, C. Estratégias Comerciais das Filiais Brasileiras de Empresas Transnacionais no contexto de abertura Econômica e Concorrência Global. Revista de Economia Contemporânea, Rio de Janeiro, 4(2): 113-141, jul/dez 2000

HOFFMANN, R. Distribuição de Renda. Medidas de Desigualdade e Pobreza. São Paulo, Editora da Universidade de São Paulo, 1998a

HOFFMANN, R. Estatística para Economistas. $3^{\text {a }}$ Edição Revisada e Ampliada, Biblioteca Pioneira de Ciências Sociais, 1998b

ISLAM, M. N. Exports expansion and economic growth: Testing for Cointegration and Causality, Applied Economics, 30, 3 (March): 415-25, 1998

JAFFEE, D. Export dependence and economic growth: a reformulation and respecification. Social Forces, 64, p. 102-18, 1985

JAYME JR., F. G. Comércio Internacional e Crescimento Econômico: O Comércio Afeta o Desenvolvimento? Revista Brasileira de Comércio Exterior, Rio de Janeiro, v. 15, n. 69, 2001 .

JIN, J. C. Export-led growth and the Four Little Dragons, Journal of International Trade and Economic Development, 4, 2 (July): 203-15, 1995

JOHANSEN, S. Statistical analysis of cointegration vectors. Journal of Economic Dynamics and Control, 12, p. 231-254, 1988

JUNG, W. S.; MARSHALL, P. J. Exports, growth and causality in developing countries, Journal of Development Economics, 18, 1 (Mai/Jun): 1-12, 1985

KAVOUSSI, R. M. Export expansion and economic growth: Further empirical evidence. Journal of Development Economics, 14, (Jan/Fev): 241-50, 1984

KENDALL, M.G.; STUART, A. The Advanced Theory of Statistics, Charles Griffin Publishers, NY, 1961

KESSING, D. B.; LALL, S. Marketing Manufactured Exports form Developing Countries: Learning Sequences and Public Support. in HELLEINER, G. E. Trade Policy, Industrialization and Development: New Perspectives. Clarendon Press, 1992 
KEYNES, J. M. Teoria Geral do Emprego, do Juro e da Moeda. Tradução Mario R. da Cruz, Coleção os Economistas, Editora Nova Cultural, 1996

KHAN, A. H.; SAQIB, N. Exports and economic growth: The Pakistan experience. International Economic Journal, 7, 53-64, 1993

KINDLEBERGER, C. P. Foreign trade and economic growth: lessons from Britain and France. The Economic History Review, p. 289-305, 1961

KINDLEBERGER, C. P.; HERRICK, B. Economic development. 3d. Edition, New York: McGraw Hill, 1977

KÓNYA, L.. Export-led growth or growth-driven export? New evidence form Granger causality analysis on OECD countries. Working Papers WP15/2000, Central European University, Department of Economics, Budapest, December, 2000

KOREISHA, S. G.; PUKKILA, T. A New Approach for Identifying Seasonal Autoregressive Time Series Forecasting Models, in Aktuarielle Ansätze für Finanz-Risiken. AFIR. 1075-1094; 1996 (acesso em 19/05/2006 às 11:00, disponível em http://www.actuaries.org/AFIR/colloquia/Nuernberg/Koreisha_Pukkila.pdf)

GERTNER, D.; REIN, I.; HAIDER, D. Marketing de Lugares. Como conquistar crescimento de longo prazo na América Latina e Caribe. Tradução Ruth Bahr, São Paulo, Prentice-Hall, 2006

KRAVIS, I. B. Trade as a handmaiden of growth: Similarities between the nineteenth and twentieth centuries, Economic Journal, 80, 320 (December): 850-72, 1970

KRUEGER, A. O. Trade policy and economic development: how we learn. American Economic Review. 87(1): 1-21, 1997

KRUGMAN, P. R. Crises Monetárias. Tradução Técnica: Nelson Cavalheiro, São Paulo, Makron Books, 2001

KRUGMAN, P. R. Internacionalismo Pop. Tradução de Ivo Korytoowski, Rio de Janeiro, Editora Campus, 1997

KRUGMAN, P. R.; OBSTFELD, M. Economia Internacional: Teoria e Política Tradutor Técnico Eliezer Martins Diniz, São Paulo, Pearson Addison Wesley, 2005

KUGLER, P. Growth, exports and Cointegration: An empirical investigation. 127, 1: 7382,1991

KUZNETS, S. Modern Economic Growth: findings and reflections. Stockholm: Sweden, Nobel Lecture, 1971

LACERDA, A. C. Empresas Transnacionais, Investimentos Diretos Estrangeiros e Exportações na Economia Brasileira na Década de noventa. Revista de Economia Aplicada, São Paulo, v. 8, n. 4, p. 619-658, 2004a

LACERDA, A. C. Globalização e Investimento Estrangeiro no Brasil. $2^{a}$ Edição, São Paulo, Saraiva, 2004b

LAKATOS, E. M.; MARCONI, M. A. Fundamentos de metodologia científica. $5^{\text {a }}$ Edição, São Paulo, Atlas, 2003 
LAKATOS, E. M.; MARCONI, M. A. Técnicas de Pesquisa: Planejamento e execução de pesquisas, amostragens e técnicas de pesquisas, elaboração, análise e interpretação de

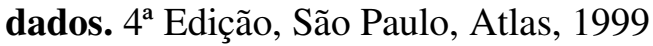

LAPLANE, M. F.; GONÇALVES, J. E. P.; ARAÚJO, R. D. Efeitos de transbordamento de empresas estrangeiras na indústria brasileira (1997-2000). NEIT, Instituto de Economia UNICAMP, Campinas, 2004

LAPLANE, M. F.; SARTI, F. Investimento Direto Estrangeiro e o Impacto na Balança Comercial nos Anos 90, IPEA, Texto para Discussão 629, Brasília, 1999 (disponível em http://www.ipea.gov.br/pub/td/td_99/td_629.pdf, acesso em 26/04/2006, às 09:30)

LASTRES, H. M. M. A Globalização e o papel das políticas de desenvolvimento industrial e tecnológico. Brasília, 1997

LEAMER, E. E. Vector autoregressions for causal inference. in BRUNNER, K.; MELTZER, A. (org.), Understanding Monetary Regimes, Journal of Monetary Economics, supplement, 255-304, 1985

LEE, F. Y.; COLE, W. E. Simultaneity in the study of exports and economic growth. International Economic Journal, 33-41, 1994

LINDER, S. E. An Essay on Trade and Transformation. Cambridge, MA: MIT Press, 1961

LOPES, L. M.; VASCONCELLOS, M. A. S. Manual de Macroeconomia: nível básico e nível intermediário. $2^{\text {a }}$ Edição, São Paulo: Atlas, 2000

LUQUINI, R. A. La Asociación Interregional entre el Mercosur y la Unión Europea: Balance Y Perspectivas. Tese de Doutorado apresentada à Universitat de València, 2003

LUSSIER, M. Impacts of exports on economic performance: A comparative study. Journal of African Economies, (Mai): 106-27, 1993

MADDALA, G. S. Introdução à Econometria. $3^{\text {a }}$ Edição, Rio de Janeiro, LTC Livros Técnicos e Científicos, 2003

MAIA, J. M. Economia Internacional e Comércio Exterior. $9^{a}$ Ed., São Paulo, Atlas, 2004

MAJID, N. Globalization and Poverty. Genebra, International Labour Organization, 2003

MANKIW, N. G. Introdução à Economia. $3^{\text {a }}$ Edição, Tradução Allan Vidigal Hastings, São Paulo: Thomsom Learning Edições, 2005

MANKIW, N. G. Macroeconomia. $3^{a}$ Edição, Tradução Maria José Cyhlar Monteiro, Editora LTC Livros Técnicos e Científicos, 1998

MARSHALL, A. Princípios de Economia: Tratado Introdutório - Natura Non Facit Saltum Volume I, Tradução revista de Rômulo Almeida e Ottolmy Strauch, Coleção os Economistas, Editora Nova Cultural, 1996

MARTINS, G. A. Pesquisas sobre administração: abordagens metodológicas. Trabalho não publicado, apresentado à Faculdade de Economia, Administração e Contabilidade da Universidade de São Paulo, 1995 
MARX, K. O Capital: Crítica da Economia Política Volume I - Livro Primeiro: O processo de produção do capital, Tradução revista de Regis Barbosa e Flávio R. Kothe, Coleção os Economistas, Editora Nova Cultural, 1996

MATARAZZO, D. C. Análise Financeira de Balanços: Abordagem básica e gerencial $5^{a}$ Edição, São Paulo, Atlas, 1998

MATOS, O. C. Desenvolvimento do Sistema Financeiro e Crescimento Econômico no Brasil: Evidências de Causalidade. Trabalhos para Discussão, Banco Central do Brasil, 2002

MATOS, O. C. Econometria Básica: Teorias e Aplicações. $3^{\text {a }}$ Edição, São Paulo, Editora Atlas, 2000

MATOS, O. C. Inter-relações entre Desenvolvimento Financeiro, Exportações e Crescimento Econômico: Análise da Experiência Brasileira. Trabalhos para Discussão, Banco Central do Brasil, 2003

MCCOMBIE, J.; THIRLWALL, A. Growth in an international context: a post keynesian view. in: DEPREZ, J.; HARVEY, J. Foundations of international economics: post keynesian perspectives. London, Routledge, 1999

MEDINA-SMITH, E. J. - Is the export-led growth hypothesis valid for developing countries - A case study of Costa Rica. Unite Nations on Trade and Development, New York and Geneva, 2001

MICHAELY, M. Exports and growth: An empirical investigation, Journal of Development Economics, 4, 1 (Mar): 49-53, 1977

MILL, J. S. Princípios de Economia Política: Com algumas de suas aplicações à Filosofia Social. Volume I, Tradução de Luiz João Baraúna, Coleção os Economistas, Editora Nova Cultural, 1996

MILLER, M. Where is globalizations taking us? Why we need a new "Bretton Woods". Futures, 27(2), pp. 125-144, 1995

MILLS, T. C. The Econometric Modeling of Financial Time Series. Cambridge University Press, 1993

MOREIRA, M. M. Estrangeiros em uma Economia Aberta: Impactos recentes sobre a Produtividade, a Concentração e o Comércio Exterior. in Organizadores GIAMBIAGI, F.; MOREIRA, M. M. A Economia Brasileira nos Anos 90, $1^{\text {a }}$ Ed., Rio de Janeiro, BNDES, 1999

MORLEY, B.; PERDIKIS, N. Trade liberalization, government expenditure and economic growth in Egypt. The Journal of Development Studies, 36(4), p. 38-54, 2000

MOSCHOS, D. Export expansion, growth and the level of economic development: An empirical analysis, Journal of Development Economics, 30, 1 (January): 93-102, 1989

MUNHOZ, C. P. B. A evolução histórica do conceito do desenvolvimento in CHEREM, M. T. C. S.; DI SENA JÚNIOR, R. (Organizadores) Comércio Internacional e Desenvolvimento: uma perspectiva brasileira. São Paulo, Editora Saraiva, 2004

NAPOLEONI, C. Curso de Economia Política 4 ${ }^{a}$ Edição, Tradução de Alberto Di Sabbato, Rio de Janeiro, Edições Graal, 1988 
NORTH, D. Institutions, Institutional Change and Economic Performance: The Political Economy of Institutions and Decisions. Cambridge University Press, 1990

NURKSE, R. Contrasting Trends in Nineteenth and Twentieth Century World Trade. in HABELER; STERN (org.) Equilibrium and Growth in the World Economy. Cambridge, 1962

NURKSE, R. Problemas da formação de capital em países subdesenvolvidos. Rio de Janeiro: Civilização Brasileira, 1957

OCAMPO, J.A.; TAYLOR, L. Trade liberalization in developing economies: modest benefits but problems with productivity growth, macro policies, and income distribution. Working papers Series I, n.8. Cepal, New School, 1998

OLIVEIRA, J. C. Evolução do índice de Desenvolvimento Humano do Brasil e do países da América Latina e do Caribe. Análise (Porto Alegre), v. 17, p. 17-27, 2006.

PARETO, V. Manual de Economia Política. Tradução de João Guilherme Vargas Netto, Coleção os Economistas, Editora Nova Cultural, 1996

PEDROSO, A. C. S. Abertura Comercial e Disparidade de Renda entre países: Uma análise empírica. Dissertação submetida à congregação da Escola de Pós Graduação em Economia para obtenção do Grau de mestre. FGV, Rio de Janeiro, 2000

PEREIRA, A. S. Uma Resenha sobre a Evolução da Teoria do Crescimento Econômico. Teoria e Evidência Econômica, v. 11, n. maio, p. 135-150, 2003.

PIMENTA JUNIOR, T. Um estudo dos fenômenos de interdependência e integração entre os principais mercados acionários emergentes da América Latina e Sudeste Asiático. Tese de Doutoramento, São Paulo: FEA USP, 2000.

PINDYCK, Robert S.; RUBINFELD, Daniel L. Econometria. Modelos e Previsões. Tradução de: Econometric models and economic forecasts, $4^{\mathrm{a}}$ Edição, Rio de Janeiro, Elsevier, 2004

PINHEIRO, A. C. O crescimento da produtividade total dos fatores e a estratégia de promoção de exportações: uma revisão da evidência internacional. Pesquisa e Planejamento Econômico, 22(1), p. 1-33, 1992

PNUD Atlas do Desenvolvimento Humano. Programa das Nações Unidas para o Desenvolvimento, 2003 (disponível em http://www.pnud.org.br/atlas/PR/Calculo_IDH.doc, acesso em 20/12/2006 às 14:30)

PORCILE, G.; CURADO, M. Rigidez na Balança Comercial e Movimentos de Capital: Uma abordagem estruturalista. Revista Brasileira de Economia (RBE), Rio de Janeiro, Jul/Set 2002

PORTER, M. A Vantagem Competitiva das Nações. Tradução Waltensir Dutra, Rio de Janeiro, Editora Campus, 1989

PREBISCH, R. Notes on trade from standpoint of the periphery. Cepal Review (28): 203214, 1986

PREBISCH, R. The economic development of Latin America and its principal problems. New York: United Nations, 1950 
PREBISCH, R. A dinâmica do desenvolvimento latino-americano. Versão traduzida de Hacia uma Dinâmica del desarrolo latinoamericano - CEPAL, Argentina, 1963

RAM, R. Exports and economic growth in developing countries: Evidence from TimeSeries and Cross-Section Data, Economic Development and Cultural Change, 36, 1 (Out): 51-63, 1987

RAM, R. Exports and economic growth: Some additional evidence. Economic Development and Cultural Change, 33, 2 (January): 415-25, 1985

RAMBO, A. I. Investimentos Estrangeiros Diretos (IED's) no Brasil a partir do Plano Real: Impactos sobre Transações Correntes (01/1994 à 06/1998). Economia e Desenvolvimento, n.13 agosto, 2001

REGO, J. M.; MARQUES, R. M. Economia Brasileira. Organizadores José Márcio Rego e Rosa Maria Marques, $2^{a}$ Edição, São Paulo, Editora Saraiva, 2006

REGO, J. M.; MARQUES, R. M. Formação Econômica do Brasil. Organizadores José Márcio Rego e Rosa Maria Marques, São Paulo, Editora Saraiva, 2003

RICARDO, D. Princípios de Economia Política e Tributação. Tradução Paulo Henrique Ribeiro Sandroni, Coleção os Economistas, Editora Nova Cultural, 1996

RICHARDS, D. G. Exports as a determinant of long-run growth in Paraguay, 1966-96. The Journal of Development Studies, 38(1), p. 128-146, 2001

RICHARDSON, R. J. Pesquisa Social: Métodos e Técnicas. Colaboradores José Augusto de Souza Peres (et al) - São Paulo: Atlas, 1999

RICUPERO, R. A busca de sentido para a economia e o desenvolvimento. in ARBIX, G.; ZILBOVICIUS, M.; ABRAMOVAY, R. Razões e Ficções para o Desenvolvimento. Organizadores: ARBIX; ZILBOVICIUS; ABRAMOVAY, vários autores, São Paulo, Editora UNESP; EDUSP, 2001a

RICUPERO, R. O Brasil e o dilema da globalização. $2^{a}$ Edição, São Paulo: SENAC, 2001b

ROCHA, E. M. P. ; FERREIRA, M. A. T. Análise dos Indicadores de Inovação Tecnológica no Brasil: Comparação entre um Grupo de Empresas Privatizadas e o Grupo Geral de Empresas. Ciência da Informação, Brasília, v. 30, n. 2, p. 64-69, 2001.

RODRÍGUEZ, F.; RODRIK, D. Trade policy and Economic Growth: a skeptic's guide to the cross-national evidence. NBER Working Papers n.5791. Cambridge, Massachussets, 1999

RODRIK, D. The new global economy and developing countries: making openness work. Washington, D.C.: Overseas Development Council, 1999

ROS, J.; LUSTIG, N. Trade and financial liberalization with volatile capital inflows: macroeconomic consequences and social impacts in Mexico during the 1990's. Paper prepared for Cepal, New School Conference on Globalization and Social Policy, 1999

SACHS, I. Repensando o crescimento econômico e o progresso social: o âmbito da política. in ARBIX, G.; ZILBOVICIUS, M.; ABRAMOVAY, R. Razões e Ficções para o Desenvolvimento. Organizadores: ARBIX; ZILBOVICIUS; ABRAMOVAY, vários autores, São Paulo, Editora UNESP; EDUSP, 2001 
SACHS, J., WARNER, A. Economic reform and the process of global integration. Brooking Papers on Economic Activity. 1: 1-117, 1995

SALA-I-MARTIN, X. The disturbing "rise" of global income inequality National Bureau of Economic Research, 2002

SALAMA, P. Novas formas da pobreza da América Latina in GENTIL, P. Globalização Excludente. Desigualdade, Exclusão e Democracia na Nova Ordem Mundial. Organizador: Pablo Gentil, $3^{\mathrm{a}}$ Edição, Petrópolis RJ: Editora Vozes, Buenos Aires: CLACSO, 2001

SANTOS, T. S. Globalização e exclusão: a dialética da mundialização do capital. Sociologias, nº. 6, p.170-198, jul. /dez. 2001

SAVÓIA, J. R. F. A globalização do mercado financeiro brasileiro: um estudo de implicações sobre competitividade. Tese de Doutorado apresentada ao Departamento de Administração da Faculdade de Administração, Economia e Contabilidade da USP, 1996

SCHUMPETER, J. A. Teoria do Desenvolvimento Econômico: Uma investigação sobre lucros, capital, crédito, juro e o ciclo econômico. Tradução de Maria Sílvia Possas, Coleção os Economistas, Editora Nova Cultural, 1996

SCHWARZ, G. Estimating the dimension of a model. Annals of Statistics 6, 461-464, 1978

SEERS, Dudley What are we tryng to measure. Journal of Development Studies, Vol 8, p.21-36, Apr/1972

SEN, A. Desenvolvimento como liberdade. São Paulo, Companhia das Letras, 2002

SENE, E. Globalização e Espaço Geográfico. $2^{a}$ Edição, São Paulo, Editora Contexto, 2004

SENGUPTA J. K. Rapid growth in NICs in Asia: Tests of New Growth Theory for Korea. Kyklos, 44, 4 (November): 561-79, 1991

SERLETIS, A. Export growth and Canadian economic development, Journal of Development Economics, 38, 1 (January): 133-45, 1992

SERVEN, A. K. The relation of exports and economic growth: Comment, Kyklos, 21, 3 (Ago): 546-48, 1968

SHAN, J.; SUN, F. On the Export-Led Growth Hypothesis: The Econometric Evidence from China”, Applied Economics, 30, 8 (Ago): 1055-65, 1998

SHEEHEY, E. J. Exports as a factor of production: A consistency test, World Development, 21, 1 (January): 155-60, 1993

SILVA, A. G; VIRGOLINO, J. R. O.; LIMA, R. C. A Lei de Thirlwall e a economia brasileira: uma breve consideração. Revista Econômica do Nordeste, 3, p. 852-864, 2000

SIMS, C.A. Macroeconomics and Reality. Econometrica. Vol. 48, Janeiro, 1980

SIMS, C.A. Money, income and causality, American Economic Review 62, 540-52, 1972

SINGER, H. W. The distribution of gains between investing and borrowing countries. American Economic Review Papers and Proceedings, 40, p. 473-85, 1950 
SINGER, H. W. The distribution of gains between investing and borrowing countries. American Economic Review Papers and Proceedings, 40, p. 473-85, 1950

SMITH, A. A Riqueza das Nações. Investigando sobre sua natureza e suas causas. Volume I, Tradução de Luiz João Baraúna, Coleção os Economistas, Editora Nova Cultural, 1996

SOARES, C. C. Introdução ao Comércio Exterior: Fundamentos Teóricos do Comércio Internacional. São Paulo, Editora Saraiva, 2004

SOUZA, N. J. Desenvolvimento Econômico. 5a Ed. Revisada, São Paulo, Editora Atlas, 2005

SPIEGEL, M. R. Estatística. $3^{\text {a }}$ Edição, Tradução e Revisão Técnica: Pedro Consentino, São Paulo: Pearson Education do Brasil, 1994

SRINIVASAN, T. N.; BHAGWATI, J. Outward-orientation and development: are revisionists right?, 1999 (http://www.econ.yale.edu/growth_pdf/cdp806.pdf, acesso em 21/07/2006, às 15:00)

STREETEN, P. Globalização: ameaça ou oportunidade? in ARBIX, G.; ZILBOVICIUS, M.; ABRAMOVAY, R. Razões e Ficções para o Desenvolvimento. Organizadores: ARBIX; ZILBOVICIUS; ABRAMOVAY, vários autores, São Paulo, Editora UNESP; EDUSP, 2001

SYRON, R. F.; WALSH, B. M. The relation of exports and economic growth: A note. Kyklos, 21, 3 (Ago): 541-45, 1968

TAYLOR, L. Economic openness: problems to century's end. in TARIG, B. Economic liberalization: no panacea, 1993

TAYLOR, L. Income distribution, inflation, and growth. Cambridge MA: MIT Press, 1991

THENUWARA, H. N. On the indeterminacy of empirical findings on export-led-growth. Staff Studies of the Central Bank of Sri Lanka, 24, 1994

THERBORN, G. Dimensões da globalização e a dinâmica das (des)igualdades. in GENTIL, P. Globalização Excludente. Desigualdade, Exclusão e Democracia na Nova Ordem Mundial. Organizador: Pablo Gentil, $3^{\text {a }}$ Edição, Petrópolis RJ: Editora Vozes, Buenos Aires: CLACSO, 2001

TODA, H; PHILLIPS, P. Vector autoregressioins and causality. Econometria, 61, pp.13671393,1993

TYLER, W. G. Growth and export expansion in developing countries: Some empirical evidence, Journal of Development Economics, 9, 1 (August): 121-30, 1981

TYLER, W. G. Substituição de importações e expansão das exportações como fontes de crescimento industrial no Brasil. Estudos Econômicos, 12(3), p. 1982

VAN DEN BERG, H.; SCHMIDT, J. R. Foreign trade and economic growth: Time series evidence from Latin America, Journal of International Trade and Economic Development, 3, 3 (Nov): 121-30, 1994

VEIGA, J. E. Desenvolvimento Sustentável: O desafio do século XXI. Rio de Janeiro, Garamond, 2005 
VERNON, R. International Investment and International Trade in Product Cycle. The Quartely Journal of Economics, Vol 80, 1966

WILLMORE, L. N. The comparative performance of foreign and domestic firms in Brazil. World Development, v. 14, n. 4, p. 489-502, 1986

WILLMORE, L. N. Transnationals and foreign trade: evidence from Brazil. Journal of Development Studies, v. 28, n. 2, p. 314-35, Janeiro, 1992

YAMADA, H. A note on the causality between export and productivity: an empirical reexaminations. Economics Letters, 61, p. 111-14, 1998

ZESTOS, G. K.; TAO, X. Trade and GDP growth: causal relations in the United States and Canada. Southern Economic Journal, 68(4), p. 859-874, 2002 